\title{
Aufkommens-, Verteilungs- und Investitionswirkungen von Steuerreformen in Deutschland und der Europäischen Union
}

Revenue consequences, redistribution effects and investment impacts of tax reforms in Germany and in the European Union

\author{
Dissertation \\ zur Erlangung des Doktorgrades \\ der Wirtschaftswissenschaftlichen Fakultät \\ der Georg-August-Universität Göttingen
}

vorgelegt von

Dorothea Vorndamme

geboren in Hannover

Göttingen, 2014 


\section{Betreuungsausschuss}

Erstbetreuer: $\quad$ Prof. Dr. Andreas Oestreicher

Weitere Betreuer: Prof. Dr. Jörg-Markus Hitz

Prof. Dr. Robert Schwager

Tag der mündlichen Prüfung: 29.01.2014 


\section{Inhaltsübersicht}

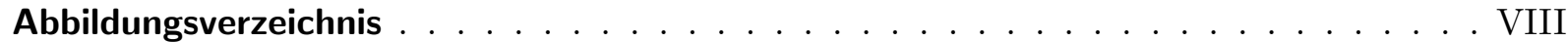

Tabellenverzeichnis $\ldots \ldots \ldots \ldots \ldots \ldots \ldots \ldots \ldots \ldots \ldots$

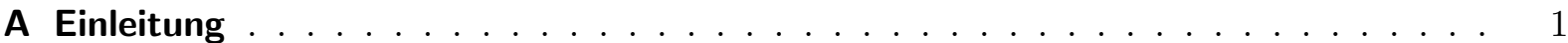

B Reforming inter-period loss-offset provisions: possible consequences for tax bill

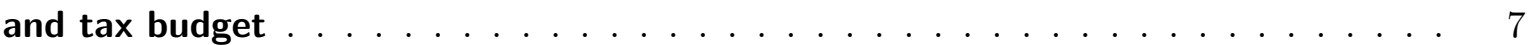

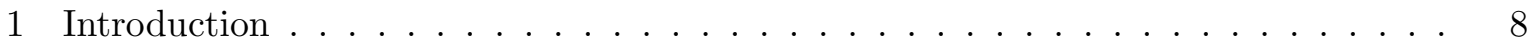

2 Possible reform scenarios . . . . . . . . . . . . . . . . . . . . . . 10

3 The Model . . . . . . . . . . . . . . . . . . . . . . . . . . . . 11

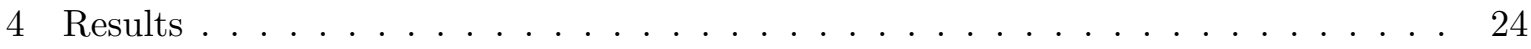

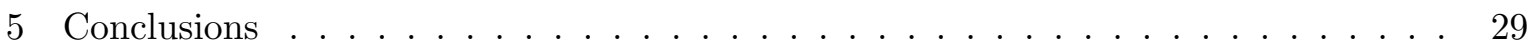

6 Appendix - Evaluation of the model . . . . . . . . . . . . . . . . . . 31

C ASSERT - Assessing the effects of reforms in taxation - a micro-simulation approach 32

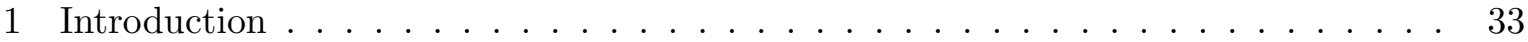

2 General approach and underlying data . . . . . . . . . . . . . 34

3 Module 1: Simulation of future company development . . . . . . . . . . . . 38

4 Module 2: Possible behavioral responses . . . . . . . . . . . . . . . . . 50

5 Module 3: Deriving tax liability . . . . . . . . . . . . . . . . . . . 51

6 Module 4: Deriving items for next year's simulation . . . . . . . . . . . . . 55

7 Module 5: Determining tax revenue and tax burden . . . . . . . . . . . 57

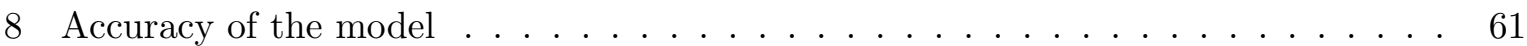

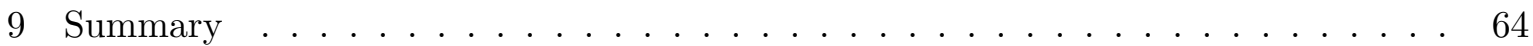

10 Appendix 1 - Generation of database . . . . . . . . . . . . . . 65

11 Appendix 2 - Database in its current version . . . . . . . . . . . . . . 84

12 Appendix 3 - Accuracy of the model - country tables . . . . . . . . . . . . . . 89

D Aufkommenswirkungen einer Abschaffung des Ergebnisabführungsvertrags bei der

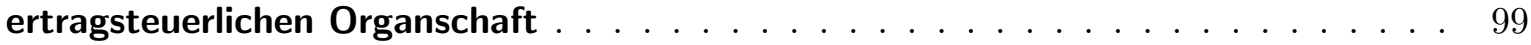

1 „Modernisierung" der Gruppenbesteuerung . . . . . . . . . . . . . . . . . . 100 
2 Eckdaten des IFSt-Modells . . . . . . . . . . . . . . . . . . 105

3 Aufkommenseffekte einer Reform der Gruppenbesteuerung nach dem IFSt-Modell 106

4 Hochrechnung der finalen ausländischen Verluste zum Jahresende 2008 . . . . . . 126

5 Zusammenfassende Würdigung der Berechnungsergebnisse . . . . . . . . . . . . . . 131

6 Mikrosimulationsmodell ASSERT . . . . . . . . . . . . . . . . . 135

7 Anhang - Reformvorschlag des Instituts Finanzen und Steuern . . . . . . . . . . . 146

E The effects of tax depreciation on the level of investment - an empirical analysis . 149

1 Motivation . . . . . . . . . . . . . . . . . . . . 150

2 Prior literature . . . . . . . . . . . . . . . . . . . . 152

3 Theoretical framework and derivation of the research hypothesis . . . . . . . . 156

4 Research design . . . . . . . . . . . . . . . . . . . . . . 162

5 Sample selection and descriptive statistics $\ldots \ldots \ldots \ldots \ldots$. . . . . . . . 172

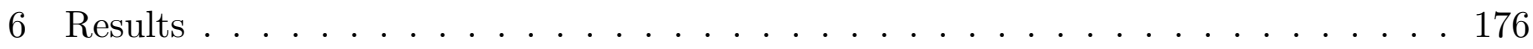

7 Concluding remarks . . . . . . . . . . . . . . . . . . . . . 192

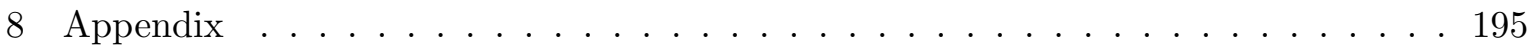

F Zusammenfassendes Fazit . . . . . . . . . . . . . . . . . . . . . . . 214

Literaturverzeichnis . . . . . . . . . . . . . . . . . . . . . . . . . 219

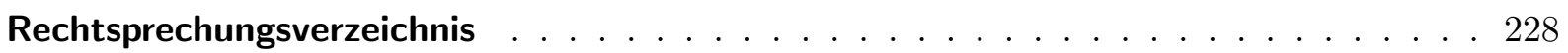

Quellenverzeichnis . . . . . . . . . . . . . . . . . . . . . . . . 229 


\section{Inhaltsverzeichnis}

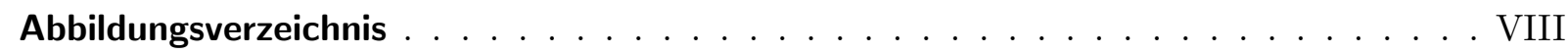

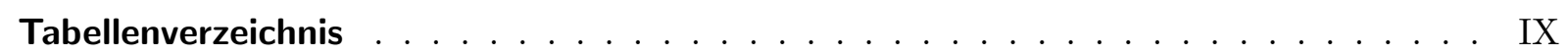

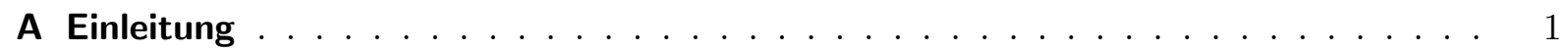

B Reforming inter-period loss-offset provisions: possible consequences for tax bill

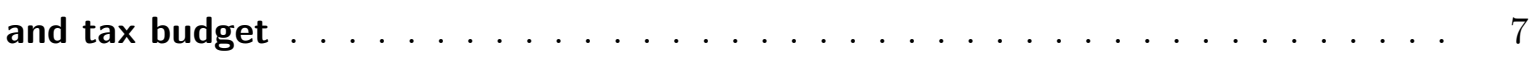

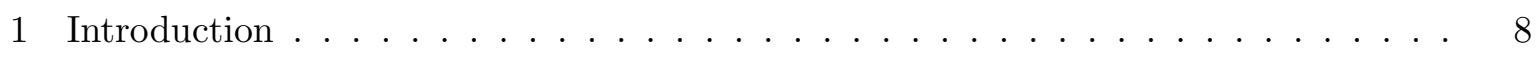

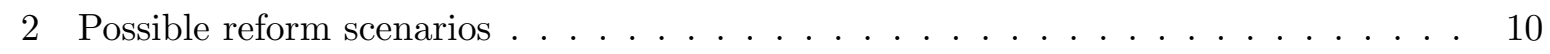

3 The Model . . . . . . . . . . . . . . . . . . . . . . 11

3.1 General approach . . . . . . . . . . . . . . . . . 11

3.2 Data . . . . . . . . . . . . . . . . . . . . . 12

3.3 Forecasting earnings and determining the effects of inter-period loss-offset . . 14

3.4 Modeling behavioral responses . . . . . . . . . . . . . . . 20

3.5 Extrapolation procedure .......................... 23

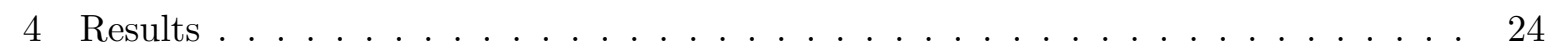

4.1 First-round effects . . . . . . . . . . . . . . . 24

4.2 Size-specific effects . . . . . . . . . . . . . . . . 26

4.3 Industry-specific effects . . . . . . . . . . . . . . . . . 27

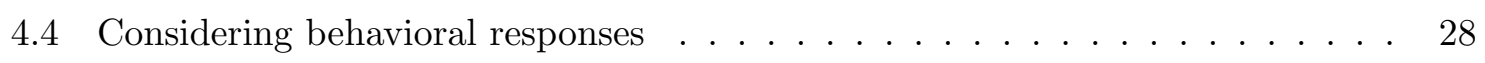

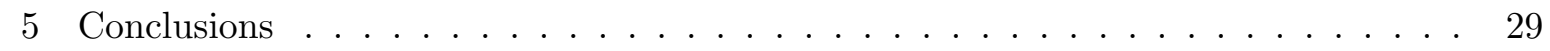

6 Appendix - Evaluation of the model . . . . . . . . . . . . . . 31

C ASSERT - Assessing the effects of reforms in taxation - a micro-simulation approach 32

1 Introduction . . . . . . . . . . . . . . . . . . . . . 33

2 General approach and underlying data . . . . . . . . . . . . . 34

2.1 General approach . . . . . . . . . . . . . . . . 34

2.2 Data requirements and structure of the data $\ldots \ldots \ldots$

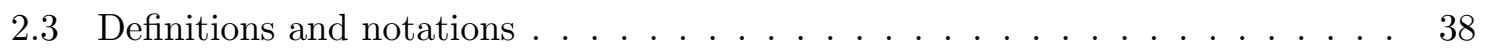

3 Module 1: Simulation of future company development . . . . . . . . . . . . 38

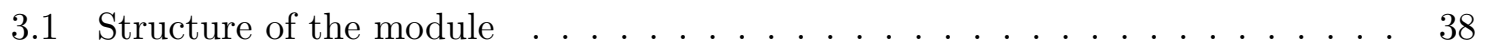


3.2 Forecasting procedures $\ldots \ldots \ldots \ldots \ldots \ldots$

3.2 .1 Forecasting approaches suggested by the literature . . . . . . . . . 39

3.2.2 Investment in tangible and intangible fixed assets . . . . . . . . . . . 40

3.2.3 Investment in other fixed assets and current assets and determination of total assets . . . . . . . . . . . . . . . . . . 44

3.2.4 Return on assets and determination of EBITDA . . . . . . . . . . 45

3.2 .5 Depreciation . . . . . . . . . . . . . . . . 46

3.2 .6 Extraordinary result $\ldots \ldots \ldots \ldots$. . . . . . . . . . . 47

3.2 .7 Financial expenses $\ldots \ldots \ldots \ldots$. . . . . . . . . . . . . 47

3.2 .8 Financial revenue . . . . . . . . . . . . . . . . . . . . . . 49

4 Module 2: Possible behavioral responses . . . . . . . . . . . . . 50

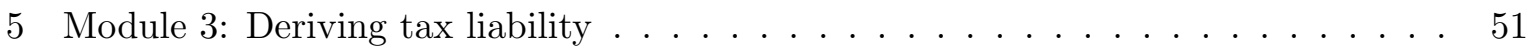

5.1 Tax liability under law in force $\ldots \ldots \ldots \ldots \ldots \ldots$

5.1 .1 General approach . . . . . . . . . . . . . . . . . . 51

5.1 .2 Determination of tax-free dividends . . . . . . . . . . . 51

5.1 .3 Group taxation . . . . . . . . . . . . . . . . 52

5.1 .4 Inter-period loss-offset $\ldots \ldots \ldots \ldots \ldots$. . . . . . . . . 54

5.2 Determining the consequences of tax reforms . . . . . . . . . . 55

6 Module 4: Deriving items for next year's simulation . . . . . . . . . . . . . 55

7 Module 5: Determining tax revenue and tax burden . . . . . . . . . . . . 57

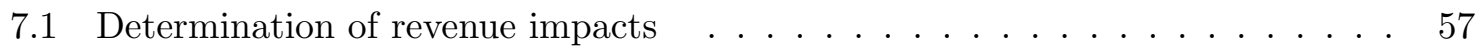

7.2 Determination of tax burden . . . . . . . . . . . . . . . . 59

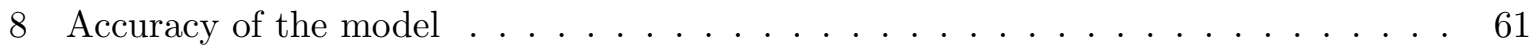

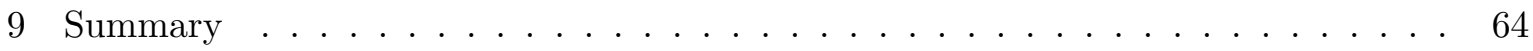

10 Appendix 1 - Generation of database . . . . . . . . . . . . . . 65

10.1 Database and data selection . . . . . . . . . . . . . . . 65

10.2 Preparation of the original data $\ldots \ldots \ldots \ldots \ldots$. . . . . . . . 67

10.2 .1 Financial data . . . . . . . . . . . . . . . . . . . 67

10.2.2 Ownership data and corporate group structures . . . . . . . . . 71

10.3 Modification of the original data $\ldots \ldots \ldots \ldots$. . . . . . . . . . . . . .

10.3.1 Structure of non-financial fixed assets . . . . . . . . . . . 73

10.3.2 Structure of financial fixed assets and financial revenue . . . . . . . . 79

10.3.3 Existing tax loss carry-forwards . . . . . . . . . . . . . 82 
10.3.4 Identification of corporate groups' industries . . . . . . . . . . . . . 84

11 Appendix 2 - Database in its current version f . . . . . . . . . . . 84

12 Appendix 3 - Accuracy of the model - country tables . . . . . . . . . . . . . 89

\section{Aufkommenswirkungen einer Abschaffung des Ergebnisabführungsvertrags bei der}

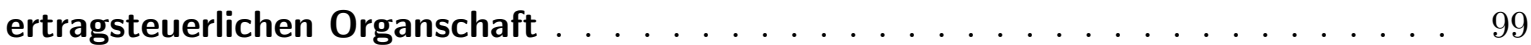

1 „Modernisierung" der Gruppenbesteuerung . . . . . . . . . . . . . . . . . . 100

1.1 Reformbedarf . . . . . . . . . . . . . . . . . 100

1.2 Berechnung von Aufkommenswirkungen . . . . . . . . . . . . . . . . . 102

1.3 Struktur dieses Berichts _. . . . . . . . . . . . . . . . . . 103

2 Eckdaten des IFSt-Modells f . . . . . . . . . . . . . . . . 105

3 Aufkommenseffekte einer Reform der Gruppenbesteuerung nach dem IFSt-Modell 106

3.1 Wirkungsdauer und Wirkungsrichtung möglicher Aufkommenseffekte . . . . . 106

3.2 Struktur der vorliegenden Aufkommensberechnungen . . . . . . . . . . . 110

3.3 Anhebung der Mindestbeteiligungsquote auf alternativ 75, 95 oder 100\% . . . 111

3.3.1 Anzahl betroffener Kapitalgesellschaften in der Stichprobe . . . . . . . 111

3.3.2 Aufkommenswirkungen . . . . . . . . . . . . . . . . . 112

3.4 Weitergehende Analysen für das Basisszenario („MBQ=75\%“) . . . . . . . 115

3.4.1 Begrenzung der Verlustverrechnung auf den Beteiligungsbuchwert . . . 115

3.4.2 Erstreckung der Verlustverrechnung auf Vorgruppenverluste . . . . . 116

3.4.3 Berücksichtigung der Wahrscheinlichkeit einer Inanspruchnahme der Gruppenbesteuerung . . . . . . . . . . . . . . . . . 117

3.5 Ergänzende Berechnungen . . . . . . . . . . . . . . . . . . 118

3.5.1 Mittelfristige Effekte . . . . . . . . . . . . . . . . 118

3.5.2 Abhängigkeit der Ergebnisse von der Höhe und Verteilung der körperschaftsteuerlichen Verlustvorträge . . . . . . . . . . 120

3.6 Verteilungswirkungen f . . . . . . . . . . . . . . . . . . . . . 122

3.6.1 Größeneffekte . . . . . . . . . . . . . . . . . . . . . . 122

3.6.2 Brancheneffekte . . . . . . . . . . . . . . . . . . . 123

3.6.3 Konzernstruktureffekte . . . . . . . . . . . . . . . . . . . . . . . . 124

4 Hochrechnung der finalen ausländischen Verluste zum Jahresende 2008 . . . . . . 126

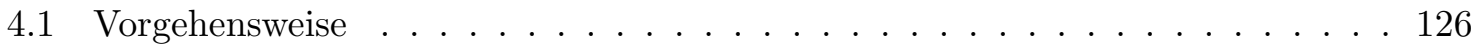


4.2 Hochrechnung auf Basis der Direktinvestitionsstatistik 2008

4.2.1 Gesamtbestand an Verlustvorträgen in Bezug auf ausländische

Tochtergesellschaften deutscher Konzerne . . . . . . . . . . 126

4.2.2 Finale Verluste in Bezug auf ausländische Tochtergesellschaften deutscher Konzerne . . . . . . . . . . . . . . . . . . . . . . 127

4.3 Hochrechnung auf Basis der Körperschaftsteuerstatistik 2007 . . . . . . . . 129

5 Zusammenfassende Würdigung der Berechnungsergebnisse . . . . . . . . . . . . . 131

6 Mikrosimulationsmodell ASSERT . . . . . . . . . . . . . . . . . . . . . . 135

6.1 Modellansatz . . . . . . . . . . . . . . . . . . . 135

6.2 Ermittlung der Bemessungsgrundlage f . . . . . . . . . . . . . . 136

6.2 .1 Datenbasis . . . . . . . . . . . . . . . . 136

6.2 .2 Operatives Ergebnis $\ldots \ldots \ldots \ldots$

6.2 .3 Finanzergebnis . . . . . . . . . . . . . . . . . . 138

6.2.4 Außerordentliches Ergebnis . . . . . . . . . . . . . . 139

6.3 Ermittlung der Steuerzahlungen f . . . . . . . . . . . . . . . 139

6.3.1 Steuerzahlungen nach geltendem Recht _. . . . . . . . . . . 139

6.3.2 Simulation von Steuerreformen _. . . . . . . . . . . . . . . 141

6.4 Ermittlung des Steueraufkommens _. . . . . . . . . . . . . . . . 141

6.5 Evaluierung der Modellgüte . . . . . . . . . . . . . . . . . . . . . . . 142

6.5.1 Prognosegüte der durch Fortschreibung ermittelten Werte . . . . . . . 142

6.5.2 Vergleich von ermittelten und tatsächlichen Verlustvorträgen . . . . . 143

6.5.3 Vergleich von ermitteltem und tatsächlichem

Körperschaftsteueraufkommen . . . . . . . . . . . . . . . 145

7 Anhang - Reformvorschlag des Instituts Finanzen und Steuern . . . . . . . . . . . 146

E The effects of tax depreciation on the level of investment - an empirical analysis $\quad 149$

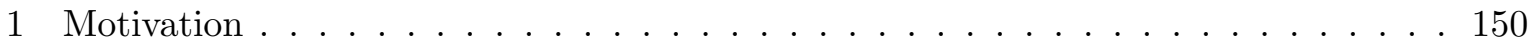

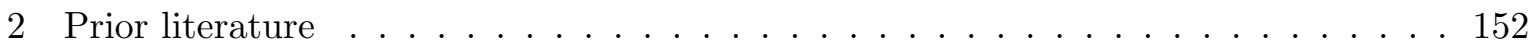

3 Theoretical framework and derivation of the research hypothesis . . . . . . . . 156

3.1 Neoclassical Theory revisited . . . . . . . . . . . . . . . . . . 156

3.2 Derivation of the impact of taxation on investment $\ldots \ldots \ldots$. . . . . . 160

4 Research design . . . . . . . . . . . . . . . . . . . . . 162

4.1 Estimation approach . . . . . . . . . . . . . . . . . . . 162 
4.2 Dependent variable(s) . . . . . . . . . . . . . . . . . . . . . . . 164

4.3 Key explanatory variables $\ldots \ldots \ldots 6$

$4.4 \quad$ Firm-specific control variables . . . . . . . . . . . . . . . . . . . . . 169

4.5 Country-specific control variables . . . . . . . . . . . . . . . . . . . . 169

4.6 Extensions of the basic model . . . . . . . . . . . . . . . . . 171

5 Sample selection and descriptive statistics f . . . . . . . . . . . . . . 172

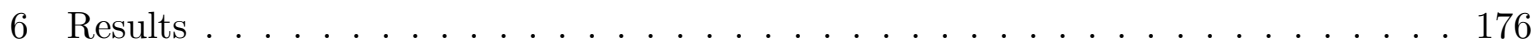

6.1 Cross-section analyses $\ldots \ldots \ldots \ldots \ldots \ldots \ldots$

6.2 Panel data analyses . . . . . . . . . . . . . . . . . . . . . 183

6.3 Robustness checks . . . . . . . . . . . . . . . . . . . . 187

6.3 .1 Dynamic specification . . . . . . . . . . . . . . . . . 187

6.3.2 Alternative definition of company size . . . . . . . . . . . . . . 190

6.3.3 Estimations based on the full sample . . . . . . . . . . . . . . . . . 191

6.3.4 Alternative capital market interest rates . . . . . . . . . . . . . . 192

7 Concluding remarks . . . . . . . . . . . . . . . . . . . . 192

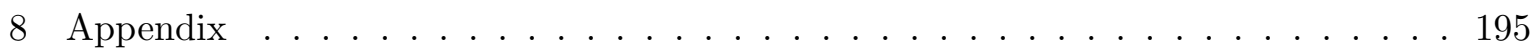

8.1 Neoclassical Theory of investment behavior - mathematical derivations . . . . 195

8.2 Data selection process $\ldots \ldots \ldots \ldots \ldots$

8.3 Definitions of variables . . . . . . . . . . . . . . . . . . . . . 198

8.4 Correlation tables . . . . . . . . . . . . . . . . . . . . . . . . 199

8.5 Dynamic panel data models . . . . . . . . . . . . . . . . . . 203

8.5.1 Ordinary least squares and within groups estimator . . . . . . . . 203

8.5.2 The difference GMM estimator . . . . . . . . . . . . . . . . 204

8.6 Results of robustness checks . . . . . . . . . . . . . 206

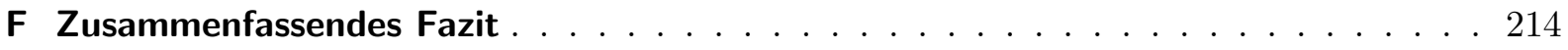

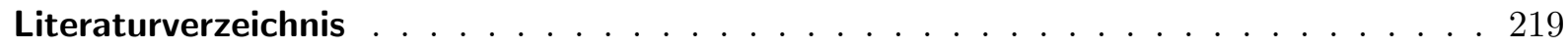

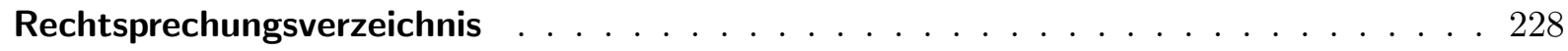

Quellenverzeichnis . . . . . . . . . . . . . . . . . . . . . . 229 


\section{Abbildungsverzeichnis}

A.1 Aufbau der vorliegenden Arbeit . . . . . . . . . . . . . 3

C.1 Structure of the micro-simulation model ASSERT . . . . . . . . . . . . 35

C.2 Simplified structure of Module $1 \ldots \ldots \ldots \ldots$

C.3 Formation of performance-size bins . . . . . . . . . . . . . . . . 42

C.4 Example of asset-type structure determination - initial situation . . . . . . . 78

D.1 Vergleich der Verlustvorträge aus ASSERT und Körperschaftsteuerstatistik . . . . 144

D.2 Vergleich des Körperschaftsteueraufkommens nach ASSERT und

Bundesministerium der Finanzen . . . . . . . . . . . . . . . . 145

E.1 Present values of depreciation allowances for patents by country and year . . . . . 167

E.2 Present values of depreciation allowances for buildings by country and year . . . 168

E.3 Present values of depreciation allowances for machinery by country and year . . . 168 


\section{Tabellenverzeichnis}

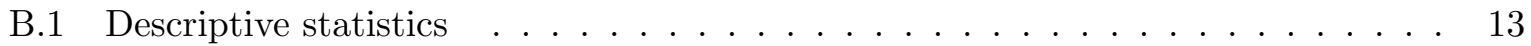

B.2 Regression of investment on growth of GDP and return on assets . . . . . . . 16

B.3 Regression of current assets on prior year current assets and changes in fixed

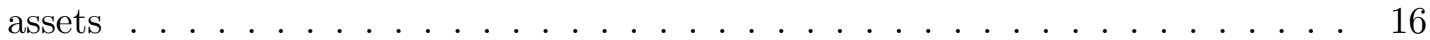

B.4 Data coverage in $2006 \ldots \ldots \ldots \ldots \ldots \ldots \ldots$

B.5 Revenue effects without considering behavioral responses . . . . . . . . . . . 24

B.6 Size-specific revenue effects without considering behavioral responses . . . . . . . 26

B.7 Industry-specific revenue effects without considering behavioral responses . . . . 27

B.8 Total relative changes in tax base from 2007 to $2012 \ldots \ldots \ldots \ldots \ldots \ldots$

B.9 Evaluation of the model (including outliers) . . . . . . . . . . . . . . . 31

B.10 Evaluation of the model (without outliers) f . . . . . . . . . . . . 31

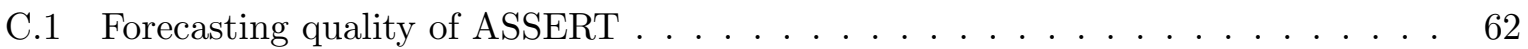

C.2 Balance sheet items available in Amadeus . . . . . . . . . . . . . . . 65

C.3 Income statement items available in Amadeus . . . . . . . . . . . . . . . 66

C.4 Preparation of ownership data . . . . . . . . . . . . . . . 71

C.5 Data coverage in Eurostat, Amadeus and ASSERT . . . . . . . . . . . . 85

C.6 Three-year datasets available for the generation of bins (comparable companies) 87

C.7 Distribution of industries among corporations and corporate groups . . . . . . 88

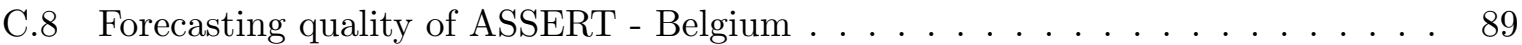

C.9 Forecasting quality of ASSERT - Czech Republic . . . . . . . . . . . . . . . . 90

C.10 Forecasting quality of ASSERT - Finland . . . . . . . . . . . . . . . 91

C.11 Forecasting quality of ASSERT - France . . . . . . . . . . . . . . . . . . 92

C.12 Forecasting quality of ASSERT - Germany . . . . . . . . . . . . . . 93

C.13 Forecasting quality of ASSERT - Italy . . . . . . . . . . . . . . . . . . 94

C.14 Forecasting quality of ASSERT - Poland . . . . . . . . . . . . . . . . . 95

C.15 Forecasting quality of ASSERT - Spain . . . . . . . . . . . . . . 96

C.16 Forecasting quality of ASSERT - Sweden . . . . . . . . . . . . . . . 97

C.17 Forecasting quality of ASSERT - United Kingdom . . . . . . . . . . . . . . 98

D.1 Zusammensetzung Kapitalgesellschaften in der Stichprobe . . . . . . . . . . . . 111 
D.2 Änderung des Körperschaftsteueraufkommens bei Abschaffung des EAV und alternativen Mindestbeteiligungsquoten . . . . . . . . . . . . . . . . . . 114

D.3 Änderung des Körperschaftsteueraufkommens bei Abschaffung des EAV, $\mathrm{MBQ}=75 \%$ und Begrenzung der Verlustverrechnung auf den Beteiligungsbuchwert115

D.4 Änderung des Körperschaftsteueraufkommens bei Abschaffung des EAV, $\mathrm{MBQ}=75 \%$ und Erstreckung der Verrechnung auf Verluste, die vor Begründung der Steuergruppe entstanden sind . . . . . . . . . . . . . . . 117

D.5 Mittelfristige Aufkommenseffekte . . . . . . . . . . . . . . . 119

D.6 Erfassungsgrad je Einkommensklasse . . . . . . . . . . . . . . . . . . 120

D.7 Bestand der körperschaftsteuerlichen Verlustvorträge laut Körperschaftsteuerstatistik und Erfassung in Amadeus und ASSERT . . . . . . 121

D.8 Zusammenhang zwischen Aufkommenswirkungen und Konzerngröße . . . . . . . 123

D.9 Zusammenhang zwischen Aufkommenswirkungen und Branchenzugehörigkeit . . 124

D.10 Zusammenhang zwischen Aufkommenswirkungen und Konzernstruktur . . . . . 125

D.11 Hochrechnung der finalen Auslandsverluste auf Basis der Direktinvestitionsstatistik $2004 \ldots \ldots \ldots \ldots$

D.12 Höhe der Verlustvorträge und Bilanzergebnis nach Körperschaftsteuerstatistik 130

D.13 Erwartete Aufkommensänderungen aus einer Abschaffung des Gewinnabführungsvertrags und einer Berücksichtigung finaler Auslandsverluste . 132

D.14 Prognosegüte von ASSERT . . . . . . . . . . . . . . . . . . . 143

D.15 Überblick über die einzelnen Elemente des Reformvorschlags . . . . . . . . . . . 146

E.1 Sample overview . . . . . . . . . . . . . . . . . . . . . . . . 174

E.2 Summary statistics . . . . . . . . . . . . . . . . . . . 175

E.3 Pooled cross-section estimates f . . . . . . . . . . . . . . . . 177

E.4 Pooled cross-section estimates including size effects _ . . . . . . . . . . 181

E.5 Economic impact of a difference in the present value of depreciation allowances for machinery of 2.390 percentage points f . . . . . . . . . . . . . 182

E.6 Panel data estimates with country fixed effects . . . . . . . . . . . . . . 184

E.7 Panel data estimates with firm fixed effects . . . . . . . . . . . . . . . 186

E.8 Economic impact of an increase of declining-balance depreciation from 20 to 30 percent - based on a panel regression analysis including firm fixed effects . . . . 187

E.9 Dynamic panel data model . . . . . . . . . . . . . . . . . . . . . . . . . . . 189 
E.10 Data selection process . . . . . . . . . . . . . . . . . 197

E.11 Variable definitions . . . . . . . . . . . . . . . . . . 198

E.12 Correlations in cross-section analysis . . . . . . . . . . . . . . . . . 199

E.13 Correlations in panel data analysis . . . . . . . . . . . . . . . . . . . . 201

E.14 Pooled cross-section estimates including size effects . . . . . . . . . . 206

E.15 Panel data estimates including size effects . . . . . . . . . . . . . . 207

E.16 Pooled cross-section estimates - original sample . . . . . . . . . . . . . . 208

E.17 Panel data estimates with country fixed effects - original sample . . . . . . . 209

E.18 Panel data estimates with firm fixed effects - original sample . . . . . . . . . 210

E.19 Pooled cross-section estimates - alternative discount rate . . . . . . . . . . . 211

E.20 Panel data estimates with country fixed effects - alternative discount rate _ . . 212

E.21 Panel data estimates with firm fixed effects - alternative discount rate . . . . 213 


\section{A Einleitung}

Sowohl das deutsche Steuerrecht als auch das Steuerrecht anderer europäischer Staaten ist vielfach Gegenstand von Reformen. Steuersysteme sollten einerseits aus ökonomischer Sicht effizient ausgestaltet sein, das heißt mit möglichst geringen Wohlfahrtsverlusten und Entscheidungsverzerrungen einhergehen. Auf der anderen Seite sind Steuerreformen in der Regel nur dann möglich, wenn sie haushaltspolitisch vertretbar sind. Das bedeutet, dass sich gegebenenfalls entstehende Aufkommensminderungen entweder in einem für angemessen erachteten Rahmen bewegen oder durch Gegenmaßnahmen kompensiert werden können. Die Quantifizierung der Aufkommenswirkungen von potenziellen Steuerreformen ist daher für die Finanzverwaltungen von erheblicher Bedeutung.

Neben der aggregierten Aufkommenswirkung sind für die Durchsetzung und die Akzeptanz von Steuerreformen Informationen bezüglich der möglichen Folgen auf der Ebene einzelner Unternehmen bedeutsam. Diese sind insbesondere dann relevant, wenn durch eine Reform bestimmte Unternehmen oder Branchen gezielt gefördert oder nicht zusätzlich belastet werden sollen. So kann es zum Beispiel entscheidend sein, ob primär große oder kleine und mittelständische Unternehmen von einer Reform betroffen sind und auf welche Branchen sich eine Reform auswirkt. Daneben ist es von Interesse, ob eine Reform unterschiedliche Auswirkungen auf Einzelunternehmen und Konzerne hat. Auf Konzernebene ist darüber hinaus zwischen nationalen und internationalen Konzernen sowie im Rahmen der internationalen Konzerne zwischen Inbound- und Outbound-Konzernen zu differenzieren.

Sowohl auf nationaler als auch auf europäischer Ebene werden gegenwärtig verschiedene Vorschläge zur Reform der Unternehmens- und Konzernbesteuerung diskutiert. So wurden im Koalitionsvertrag zwischen CDU, CSU und FDP für die 17. Legislaturperiode (CDU et al., 2009) die Einführung eines „modernen“ Gruppenbesteuerungssystems und die Evaluation verschiedener Möglichkeiten zur Reform der intertemporalen Verlustverrechnung als Ziele definiert. Es ist davon auszugehen, dass diese Ziele auch zukünftig weiter verfolgt werden, da zwar bereits einige Reformvorhaben in diesem Zusammenhang realisiert wurden, wesentliche Kritikpunkte aber weiterhin bestehen. ${ }^{1}$ Darüber hinaus wird in der Europäischen Union gegenwärtig die Einführung einer Gemeinsamen Konsolidierten Körperschaftsteuerbemessungsgrundlage geprüft (zum Richt-

\footnotetext{
${ }^{1}$ So wurde zum Beispiel durch das Gesetz zur Änderung und Vereinfachung der Unternehmensbesteuerung und des steuerlichen Reisekostenrechts vom 20. Februar 2013 der doppelte Inlandsbezug im Rahmen der ertragsteuerlichen Organschaft gelockert und der Verlustrücktrag von $€ 511.000$ auf $€ 1.000 .000$ angehoben. Grundlegende Kritikpunkte in Bezug auf den Ergebnisabführungsvertrag als Voraussetzung für die ertragsteuerliche Organschaft oder die Mindestbesteuerung im Rahmen der intertemporalen Verlustverrechnung haben hingegen weiterhin Bestand.
} 
linienvorschlag siehe Europäische Kommission, COM(2011) 121/4). Dieser Reformvorschlag sieht vor, den Gesamterfolg der einem Konzern zugehörigen Unternehmen zu bestimmen, diesen anhand einer definierten Formel auf die einzelnen Konzerngesellschaften zu verteilen und anschließend in den Ansässigkeitsstaaten der Konzerngesellschaften der Besteuerung zu unterwerfen. In diesem Zusammenhang ist auch eine Vereinheitlichung der Gewinnermittlungsvorschriften für Konzernunternehmen in der Europäischen Union vorgesehen.

Vor diesem Hintergrund werden im Rahmen der ersten drei Beiträge dieser Arbeit die Aufkommenswirkungen zweier verschiedener Reformszenarien untersucht. Mögliche Verhaltensreaktionen von Unternehmen infolge einer Änderung der steuerlichen Vorschriften werden dabei im ersten Beitrag zwar berücksichtigt, finden dort jedoch lediglich in Form einer Szenarioanalyse Eingang. Der vierte Beitrag ist der empirischen Ermittlung unternehmerischer Verhaltensreaktionen gewidmet. Den Aufbau der Arbeit sowie den Zusammenhang der einzelnen Beiträge zeigt Abbildung A.1. Die durchgehenden Pfeile deuten darauf hin, dass die ersten drei Beiträge unmittelbar aufeinander aufbauen, während der gestrichelte Pfeil eine für die Zukunft geplante Verknüpfung der Ergebnisse des vierten Beitrags mit dem Mikrosimulationsmodell ASSERT darstellt. Die einzelnen Teile der Arbeit werden im Folgenden erläutert.

Im Hinblick auf das im ehemaligen Koalitionsvertrag definierte Ziel einer Evaluation verschiedener Modelle zur intertemporalen Verlustverrechnung wird im Rahmen des ersten Beitrags ( „Reforming inter-period loss-offset provisions: possible consequences for tax bill and tax budget") ein prototypisches Mikrosimulationsmodell entwickelt, mit dessen Hilfe die Aufkommenswirkungen einer Reform der Verlustverrechnungsvorschriften in Deutschland abgebildet werden. Daneben wird analysiert, wie sich die ermittelten Aufkommenswirkungen auf verschiedene Branchen verteilen und welche Unternehmen in Abhängigkeit von der Unternehmensgröße von den Reformoptionen betroffen wären. Mit Hilfe einer Szenarioanalyse wird darüber hinaus geprüft, wie sich Verhaltensreaktionen von Unternehmen als Konsequenz der Reformoption auf das Steueraufkommen auswirken könnten. Um eine möglichst genaue Abbildung der Aufkommenswirkungen zu gewährleisten, wird im Rahmen dieser Forschungsfrage auf Mikrodaten zurückgegriffen, die mit Hilfe einer dynamischen Mikrosimulation verarbeitet werden. Zu diesem Zweck werden zunächst handelsrechtliche Unternehmensergebnisse in die Zukunft fortgeschrieben. Das fortgeschriebene handelsrechtliche Ergebnis wird darauf aufbauend in das steuerliche Ergebnis überführt, aus dem die entsprechenden Steuerzahlungen abgeleitet werden. Die Steuerzahlungen werden dabei sowohl für das derzeit geltende Recht als auch für die entsprechenden Reformszenarien berechnet. 
Abbildung A.1: Aufbau der vorliegenden Arbeit

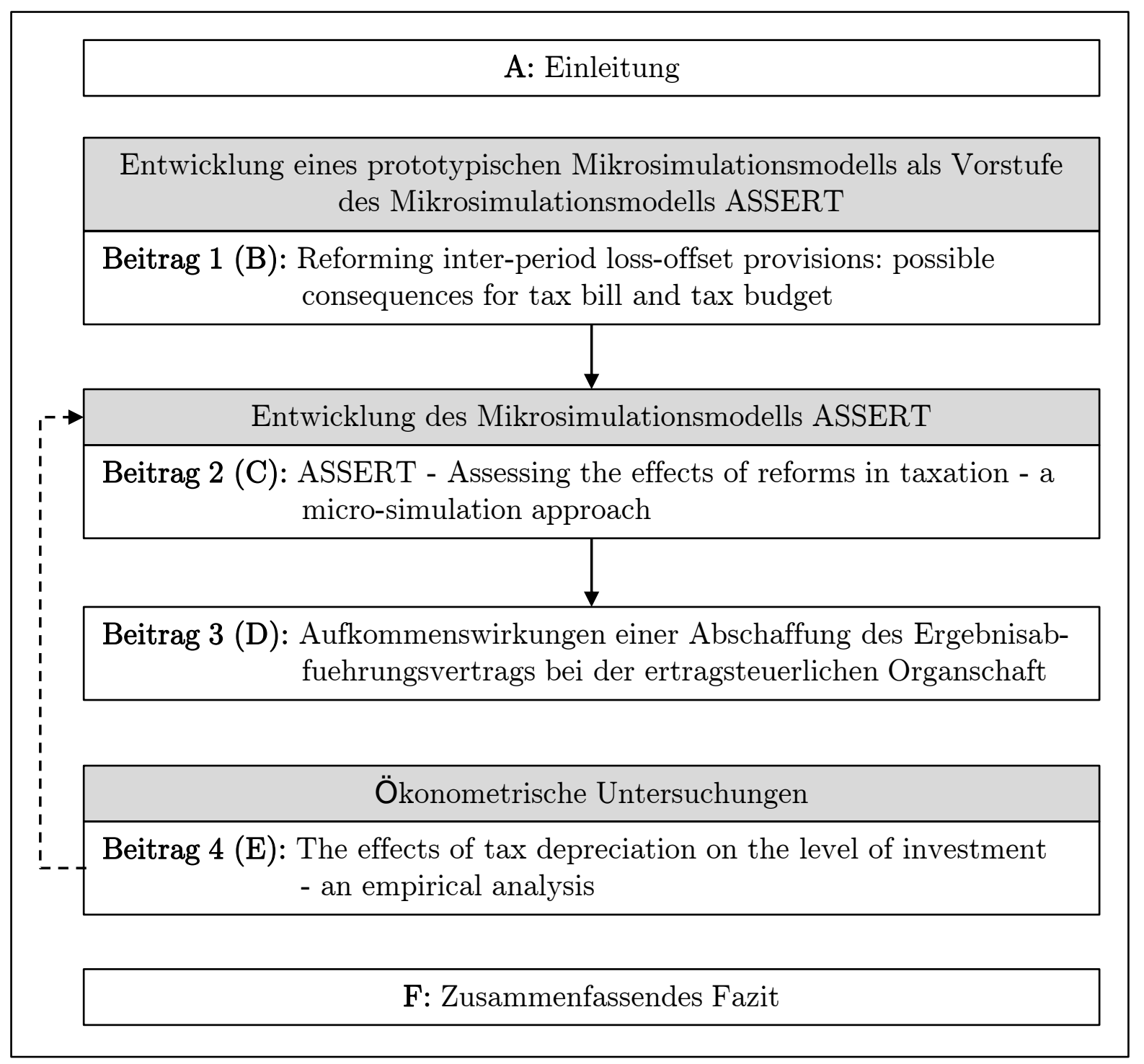

Quelle: Eigene Darstellung.

Im Gegensatz zu bereits bestehenden Mikrosimulationsmodellen auf Unternehmensebene, die überwiegend auf realisierten Daten aufsetzen (siehe zum Beispiel die Modelle in Oropallo \& Parisi, 2005, Bontempi et al., 2005 oder Reister et al., 2008), hat das im ersten Beitrag entwickelte Simulationsmodell insbesondere den Vorteil, dass eine Fortschreibung der Mikrodaten in die Zukunft vorgenommen wird. Zwar bieten vergangenheitsbezogene Modelle den Vorzug, dass sie bereits realisierte Daten verarbeiten können und so ein eventuell durch die Fortschreibung entstehender Messfehler vermieden werden kann. Auf der anderen Seite liegt vergangenheitsbezogenen Modellen die Annahme zugrunde, dass die Effekte einer in der Zukunft liegenden Steuerreform denjenigen Effekten entsprechen, die entstanden wären, wenn die Reform in der Vergangenheit durchgeführt worden wäre. Diese Annahme ist umso restriktiver, je größer der zeitliche Abstand zwischen den verwendeten Daten und dem (potenziellen) Inkrafttreten der Reform ist. 
Ein weiterer Vorteil der Fortschreibung vergangenheitsbezogener Daten in die Zukunft ist die daraus resultierende Erleichterung einer Implementierung möglicher Verhaltensreaktionen, da es in diesem Fall nicht notwendig ist, bereits realisierte Daten zu verändern.

Das prototypische Mikrosimulationsmodell weist an einigen Stellen Erweiterungspotenzial auf. So bezieht sich das Modell lediglich auf Deutschland, was zur Folge hat, dass es weder möglich ist, Steuerreformen auf europäischer Ebene zu simulieren noch mögliche Effekte deutscher (oder allgemein nationaler) Steuerreformen auf das Steueraufkommen anderer Länder einzubeziehen. Darüber hinaus ist insbesondere die Abbildung von Konzernstrukturen (und somit von Gruppenbesteuerungssystemen) im Rahmen dieses Simulationsmodells nicht vorgesehen. Aufbauend auf dem bestehenden prototypischen Ansatz, dessen Entwicklung der Bearbeitung der ersten Forschungsfrage diente, wurde daher das Mikrosimulationsmodell ASSERT entwickelt, das in Beitrag 2 („ASSERT - Assessing the effects of reforms in taxation - a micro-simulation approach") vorgestellt wird. Das Mikrosimulationsmodell wurde im Zusammenhang mit dem Forschungsprojekt „Besteuerung von Konzernen in Europa“ erarbeitet, das von der Deutschen Forschungsgemeinschaft gefördert wurde. Während im Rahmen des prototypischen Ansatzes lediglich Deutschland betrachtet und primär ein Fortschreibungsalgorithmus für das handelsrechtliche Ergebnis erarbeitet und getestet wurde, ist das Mikrosimulationsmodell ASSERT wesentlich detaillierter ausgestaltet, bezieht weitere europäische Länder mit ein und ermöglicht die Berücksichtigung von Konzernstrukturen. Es ist in der Lage, die Unternehmensentwicklung auf Basis der historischen, handelsrechtlichen Jahresabschlüsse progressiv fortzuschreiben und daraus die steuerliche Bemessungsgrundlage abzuleiten. Im Vergleich zu dem prototypischen Simulationsmodell im ersten Beitrag ist der Fortschreibungsalgorithmus im Mikrosimulationsmodell ASSERT wesentlich differenzierter ausgestaltet, sodass nicht nur das handelsrechtliche Ergebnis sondern die gesamte Bilanz fortgeschrieben wird. Da das Modell Unternehmen aus verschiedenen Ländern der Europäischen Union umfasst, können zum einen die Auswirkungen von Steuerreformen in Deutschland und in der Europäischen Union simuliert werden; zum anderen ist die Abbildung von Konzernstrukturen möglich, sodass auch Reformen der Gruppenbesteuerung oder der deutschen Organschaft abgebildet werden können.

Das Mikrosimulationsmodell ASSERT ist bereits zwei Mal zur Ermittlung von Aufkommenswirkungen zum Einsatz gebracht worden. Das im ehemaligen Koalitionsvertrag definierte Ziel der Einführung eines „modernen“ Gruppenbesteuerungssystems war dabei der Ausgangspunkt der ersten Untersuchung, die im Rahmen eines vom Institut für Finanzen und Steuern geförderten Drittmittelprojektes durchgeführt wurde. So wird im Rahmen des dritten Beitrags 
( „Aufkommenswirkungen einer Abschaffung des Ergebnisabführungsvertrags bei der ertragsteuerlichen Organschaft") untersucht, wie sich eine Reform der deutschen Organschaftsbesteuerung auf das deutsche Steueraufkommen und die betroffenen Unternehmen auswirken würde. Dabei werden insbesondere die Auswirkungen einer Abschaffung des Ergebnisabführungsvertrags und einer Anhebung der Mindestbeteiligungsquote auf das Steueraufkommen analysiert, sowie Branchen-, Größen- und Konzernstruktureffekte ermittelt. Darüber hinaus wurde das Mikrosimulationsmodell ASSERT im Rahmen des Projektes „Gemeinsame Körperschaftsteuerbemessungsgrundlage (GKB) bzw. Gemeinsame Unternehmensteuerbemessungsgrundlage (GUB): Volkswirtschaftliche Folgenabschätzung“ des Bundesministeriums der Finanzen eingesetzt, das jedoch nicht Gegenstand dieser Arbeit ist.

Steuerreformen im Allgemeinen sowie die untersuchten Reformoptionen im Speziellen wirken sich in der Regel nicht nur auf das Steueraufkommen der beteiligten Staaten, sondern auch auf das (Investitions-) Verhalten der von den Reformen betroffenen Unternehmen aus. Die Untersuchung des Einflusses von Steuern und Steuerreformen auf die Entscheidungen von nationalen und internationalen Unternehmen stellt in der betriebswirtschaftlichen Steuerlehre eine häufig untersuchte Fragestellung dar (für einen Überblick siehe zum Beispiel Hines, 1999, Shackelford \& Shevlin, 2001, Devereux \& Maffini, 2006, Hanlon \& Heitzman, 2010 und Heckemeyer \& Overesch, 2012). Von besonderem Interesse sind hierbei die Auswirkungen von Steuern auf das Investitionsverhalten von Unternehmen, da sich Investitionen sowohl direkt auf Wachstum und Beschäftigung auswirken als auch indirekt, wie zum Beispiel durch Innovationen oder externe (Lern-)Effekte. So ist es möglich, dass Unternehmen durch Innovationen in die Lage versetzt werden effizienter zu arbeiten und sie aus den (erfolgreichen oder nicht erfolgreichen) Investitionen anderer Unternehmen lernen.

Gegenstand des vierten Beitrags („The effects of tax depreciation on the level of investment - an empirical analysis") ist vor diesem Hintergrund die Investitionswirkung von Regelungen zur steuerlichen Abschreibung. Dabei wird empirisch untersucht, inwieweit umfassende Abschreibungsvorschriften tatsächlich positive Auswirkungen auf das Investitionsverhalten von Unternehmen haben. Es wird außerdem analysiert, ob diese Investitionswirkungen in Abhängigkeit von der Unternehmensgröße variieren und sich Unterschiede für Unternehmen ergeben, die im Besitz steuerlicher Verlustvorträge sind. Diese Fragestellung ist insbesondere vor dem Hintergrund der Überlegungen bezüglich einer Gemeinsamen Konsolidierten Körperschaftsteuerbemessungsgrundlage relevant, da im Zusammenhang mit der Bestimmung einheitlicher Gewinnermittlungsvorschriften auch einheitliche Abschreibungsvorschriften festge- 
legt werden müssen. Die Analyse bezieht sich auf Unternehmen aus sieben Ländern der Europäischen Union und erfolgt mit Hilfe ökonometrischer Methoden. Da der Datensatz handelsrechtliche Jahresabschlüsse europäischer Unternehmen und somit die Entwicklung der Unternehmen im Zeitablauf enthält, können sowohl Cross-Section- als auch Panel-Analysen durchgeführt werden.

Die Investitionswirkungen von Abschreibungsvorschriften sind jedoch nicht nur vor dem Hintergrund der möglichen Einführung einer Gemeinsamen Konsolidierten Körperschaftsteuerbemessungsgrundlage von Bedeutung. Vielmehr wäre es wünschenswert, das entwickelte Mikrosimulationsmodell ASSERT um sogenannte Zweitrundeneffekte, das heißt die (Verhaltens-)Reaktionen von Unternehmen auf Steuerreformen, zu erweitern. So ist es zum Beispiel möglich, dass aus Unternehmenssicht verbesserte Abschreibungsregelungen zwar zunächst zu einem Rückgang des Steueraufkommens führen, dieser Rückgang aber in den Folgejahren durch steigendes Investitionsvolumen kompensiert wird. Für eine ganzheitliche Analyse der Aufkommenseffekte von Steuerreformen ist die Berücksichtigung unternehmerischer Verhaltensreaktionen daher unerlässlich. Um dies zu gewährleisten, ist es zunächst notwendig, die zu implementierenden Verhaltensreaktionen empirisch zu ermitteln. Ein erster Beitrag dazu wird mit der vierten Untersuchung dieser Arbeit geleistet. 


\title{
B Reforming inter-period loss-offset provisions:
}

\section{possible consequences for tax bill and tax}

\section{budget}

\author{
Together with Andreas Oestreicher and Reinald Koch
}

Published in: DBW - Die Betriebswirtschaft (72), 6/2012, page 487-502

ISSN: 0342-7064

Available under:

http://www.dbwnet.de/?mod=docDetailEdocID=2932_12Effromtoc=1

\begin{abstract}
*
The paper presents a micro-simulation analysis aimed at evaluating, with respect to tax bill and tax budget, possible consequences of company tax reforms regarding inter-period loss-offset. The underlying simulation approach is capable of analyzing direct effects of policy reforms on the level of corporations, extrapolating company data over time and considering behavioral responses by way of a scenario analysis.
\end{abstract}

\footnotetext{
*We thank two anonymous referees, Andreas Haufler and the participants of presentations at the IIPF Congress 2011, the EAA Annual Congress 2011 and the Workshop of Current Research in Taxation 2011. The usual disclaimer applies.
} 


\section{Introduction}

According to the coalition agreement of the German government for the 17th legislative period mid-term tax policy is aimed at modernizing company taxation and designing it (revenue neutrally) in a way as to enhance international competitiveness of German businesses. Irrespective of legal form, organizational form, and the source of finance, company decisions should be guided first and foremost by economic aspects, but not by tax considerations. Besides introducing a "modern" group taxation system and reforming cross-border taxation of company revenue, the coalition planned also to examine whether new provisions governing inter-period loss-offset would be useful (CDU et al., 2009).

Over recent years, the German tax rules for offsetting losses have been subject of intensive discussion and a number of reforms. Recent examples are the parliamentary inquiry of some members of the German parliament from February 2nd, 2011 (see BT-Drucks. 17/4279), and relevant articles in German daily newspapers (e.g., Financial Times Deutschland, December 29, 2010 or Handelsblatt, April 6, 2011). Since 2004 losses can, for lack of positive income in the previous year or because no application of loss carry-back was made, be carried forward for an unlimited period, whereas offsetting losses against future income is limited in amount. In particular, loss carry-forwards may only be deducted without limitation up to a basic amount of $€ 1$ million. In excess of this sum, deductibility is possible at a maximum of 60 percent ("minimum taxation"). Loss carry-forwards not yet compensated as a result of this regulation can be offset against income arising in subsequent assessment periods, but are subject to the same restrictions.

For the taxpayer this limitation to usage of loss carry-forward leads to a situation in which the fiscal authority does not participate in losses to the same extent as in profits. ${ }^{1}$ Where the possibilities of loss-offset are restricted, an investor is not indifferent when weighing up a choice between two investment alternatives which, having the same net present value, differ in terms of the probability of interim losses arising. If such restrictions are not compensated, for example by granting interest on the losses carried forward, risky investments are disadvantaged by taxation as compared to risk-free investments. The danger thus arises that investments making sense for business and economic reasons are held back or even prevented (Schneider, 2002). A further

\footnotetext{
${ }^{1}$ Whether or not this must be seen as a violation of the constitutionally laid down ability-to-pay principle is evaluated variously in the literature. A survey can be found in German Federal Tax Court, Resolution dated 26.8.2010 I B 49/10; according to this resolution, however, it is more than doubtful that minimum taxation is in line with constitutional requirements if the offset of losses is finally impossible for legal reasons. See also Altfelder, 2000, Herzig \& Wagner, 2004, Lang \& Englisch, 2005, or Hackmann, 2006, in this respect.
} 
consequence is that in times of crisis the risk of illiquidity and susceptibility to insolvency is increased (Grotherr, 1998). Enterprises may therefore see themselves as being forced to diversify their operations or merge with companies in other sectors.

Against this background, calls for an end to minimum taxation in a budget-acceptable manner come as no surprise (Lüdicke et al., 2010; Dorenkamp, 2010). Abandoning minimum taxation, however, would not be without risk to the fiscal authority. On this note, the tax authorities and political decision makers draw attention to the large sums being carried forward, which may absorb the corporate and trade tax revenue for years to come should this loss carry-forwardpotential be set off against revenue generated by these taxes. According to corporate and trade tax statistics, losses carried forward amounted to more than $€ 1,000$ billion ( $€ 473$ billion corporate income tax and $€ 569$ billion trade tax losses) in 2004 (Destatis, 2009a; Destatis, 2009b), and, when projected to 2010, may even give rise to a sum in the order of $€ 1,400$ billion (Dorenkamp, 2010). But, if one takes account of the fact that these statistics include the public sector as well as permanently loss-making companies and that usage of these losses carried forward is in each year restricted to the amount of profits, it is unclear to what extent losses calculated on the basis of statistics would actually become effective (Grotherr, 1998).

In contrast to legal and theoretical analyses, consequences of loss-offset provisions with regard to tax bill and tax budget were addressed in the literature on only few occasions. Müller, 2006, uses official corporate income tax statistics from 1989 to 2001 to illustrate and analyze the size and structure of tax losses, the distribution of these losses among taxpayers as well as revenue consequences. His analysis is based on historical and (mainly) aggregated tax data. Dwenger, 2008, uses the micro-simulation model BizTax (for a detailed description of the model see Bach et al., 2008) to evaluate fiscal and distributional effects of loss-offset restrictions. She uses comprehensive tax data sets on German corporations for the years 1998 and 2001 and analyzes the revenue effects of (1) the restriction of loss carry-back to $€ 1$ million or $€ 511,500$, respectively, and (2) the introduction of minimum taxation. Dorenkamp, 2010, is, to the best of our knowledge, the only study estimating future revenue effects of changes regarding loss-offset provisions. He uses historical corporate and trade tax data for the year 2004 that show also the extent to which losses carried forward were actually utilized. Taking these statistics as the point of departure, his expected revenue reduction resulting from abolition of minimum taxation amounts to less than 5 percent of total corporate income and trade tax revenue. However, these estimates are based on historical, aggregated data and therefore do not allow for a precise estimation of revenue effects. Above all, Dorenkamp does not consider possible responses by 
enterprises. Hence, none of the above mentioned studies analyzes the impact of different lossoffset provisions on tax revenue in both a forward-looking manner and at the level of micro units (i. e., at the level of individual corporations).

In order to provide relevant support to policy-makers this paper therefore aims at developing an approach which allows us to determine the impact of reforming the provisions of inter-period loss-offset using company micro data and information on behavioral responses. Deliberations with respect to the methodological fit into the tax system, questions of manageability, or an assessment of the various alternatives from a constitutional perspective are outside the goal of this study. Against this background the present paper is structured as follows. A short discussion of the alternatives discussed in terms of reforming minimum taxation from a tax policy perspective is given in Section 2, while Section 3 serves to present the developed micro simulation approach. The results are presented and discussed in Section 4 whereas Section 5 offers conclusions.

\section{Possible reform scenarios}

In principle, terminating minimum taxation could be achieved in various ways. A first alternative, which may be regarded preferable from a systematic perspective, would be to abandon minimum taxation without substituting it with any other form of limitation. In light of the budgetary consequences it is, however, also conceivable to introduce, instead, a limitation of loss carryforward in time (Müller-Gatermann, 2010; Möhlenbrock, 2010; Rödder, 2010; Kirchhof et al., 2001), as it is the case in a number of EU member states (Endres et al., 2007). In this context, it is common practice to limit loss carry-forward to a period of five to fifteen years. If it is taken into account that losses of a company may not only rest on operational causes, but can also be attributable to the fact that the taxpayer seeks to take advantage of particular tax incentives or other benefits, a further consideration is to limit abolition of minimum taxation to operating losses (German Federal Tax Court dated 9.5.2001 XI B 151/00, Federal Tax Gazette II 2001, 554). Moreover, there is discussion of the possibility of limiting minimum taxation to negative income accrued until 2010, while lifting limitation with respect to "new" losses ("phasing out") (Lüdicke et al., 2010). A final proposal considers reducing, over the course of a transitional period, the current percentage of 40 percent of profits being subject to minimum taxation (Dorenkamp, 2010).

In consideration of the data required if one intends to evaluate these reform proposals, it becomes clear that relevant information is not available for all of them in sufficient detail. The 
analysis in the following therefore focuses on three different reform scenarios. Firstly, the effects of a cancellation of minimum taxation are considered. Such abolition of minimum taxation would lead to the result that offsetting losses against income earned in future assessment periods would no longer be limited in amount and would guarantee that the companies concerned are subject to tax on income only insofar as future income exceeds the total losses that have accrued to the company in the past. The second reform scenario under consideration is the limitation of the overall loss carry-forward period available to seven years. It will be assumed that limiting such deductibility is applied in a straightforward manner, i.e., limitation holds for both past and future profits, such that the carry-forward of losses that accrued seven years ago is no longer possible. Thirdly, further scrutiny is given to the possible abolition of loss carry-back (currently, in Germany an amount of $€ 511,500$ out of the loss for the year can be carried back to the previous year). In addition a scenario where all three reform alternatives are implemented simultaneously is analyzed.

\section{The Model}

\subsection{General approach}

The present paper aims at estimating the effects of different inter-period loss-offset provisions on both tax bill and tax budget. In order to meet this objective, we employ a forward-looking approach that uses forecasting methods to derive a fair presentation of future company performance. Our calculations are based on company-specific micro-data for the years 1994 to 2007 which are translated into forecasts of future company development for a period of six years (2007 to 2012). That is, where data is available for 2007, this year forms the basis of our forecast starting with 2008. If data is not available for 2007, as is the case for a large number of companies in the AmAdeus update underlying this study, the year 2006 is taken as a basis, with the consequence that the figures for 2007 have to be estimated. In this context, behavioral responses are also taken into account. To this end, we consider the elasticity of (i) the capital structure, (ii) investments and (iii) operative risk-taking in terms of a change in loss-offset provisions by way of a scenario analysis. In a further step, the forecasted earnings are translated into tax expenses. As our approach is capable of determining the relevant tax expenses both under the law currently in force and under the possible reform scenarios, we are in a position to derive the possible tax outcomes from the perspective of both business and the fiscal authorities by reporting the relative change in aggregated tax payments over the simulation period, i. e., January 1, 2007 is the 
considered date of reform. In order to deal with possible distortions resulting from the fact that our sample suffers from a lack of full representation, the business population as reported in the German corporate income tax statistics 2006 (Destatis, 2010) is used for purposes of adjusting the number of corporations per income class.

Applying a forward-looking simulation approach for the underlying question brings with it two advantages if compared to making direct use of historic data. Firstly, given that the available company data is limited to the years 1994 to 2007, using realized data would cause a substantial time-lag between the actual reform date and the simulation period. Secondly, and more importantly, a forward-looking simulation approach facilitates the incorporation of behavioral responses by allowing for an adjustment of specific simulation parameters instead of requiring a modification of realized profits and losses, the latter of which is considered by the authors as being more complex. Moreover, employing a forward-looking approach allows us to incorporate liquidity effects resulting from a change in the tax system.

In order to keep the time-lag between simulation period and reform date as small as possible we refer to the last available company data (year 2007 or 2006, see above) as the starting point for our simulation. Using this starting point should avoid severe distortions of the simulation given that these years were not characterized by an exceptionally good or bad economic development. In interpreting the results it has to be taken into account, however, that these financial statements do not reflect any company responses to the 2008 company tax reform. By relying on pre-reform data we implicitly assume that the applied forecasting process is not affected by the reform. This assumption is unavoidable given the unavailability of post-reform data.

\subsection{Data}

Employing the database Amadeus (our analysis is based on updates 125 (February 2005) and 172 (January 2009)) the following analysis is based on company micro-data. AmADEus contains standardized (consolidated and unconsolidated) annual accounts (for up to fourteen years), financial ratios, activities, and ownership information for the companies included. In general, AMADEUs covers all companies for which plausible and up-to-date information is available. The completeness of information provided in this database therefore depends on its availability in each case. Our analysis includes all German corporations for which a minimum of five unconsolidated financial statements are available in AMADEus for the period 1994 to 2007. These need to show at least the balance sheet total, the amount of other fixed assets, depreciation and operating profit/loss for the year. Following this selection procedure our database comprises 2,236 
corporations with a total of 17,990 firm-year observations. This company panel consists to 24.82 percent of small, 19.86 percent medium-sized and 55.32 percent large corporations. Table B.1 shows descriptive statistics for the balance sheet total, return on assets and loss carry-forwards for each size class in year 2006.

Table B.1: Descriptive statistics

\begin{tabular}{lccrrr}
\hline \multicolumn{1}{c}{ Variable } & Number & Mean & Std. Dev. & Min & Max \\
\hline Balance sheet total in & 1,000 euro & (2006), Source: & AmADEUS & & \\
All corporations & 2,202 & 146,652 & 803,428 & 15 & $33,000,000$ \\
- small & 579 & 1,794 & 1,369 & 15 & 4,803 \\
- medium-sized & 413 & 10,667 & 4,338 & 4,925 & 19,232 \\
- large & 1,210 & 262,382 & $1,070,279$ & 19,282 & $33,000,000$ \\
\hline Return on assets in percent (2006), & Source: AMADEUS & & \\
All corporations & 2,202 & 0.149 & 0.191 & -1.923 & 2.286 \\
- small & 579 & 0.165 & 0.209 & -1.923 & 0.856 \\
- medium-sized & 413 & 0.157 & 0.197 & -1.231 & 1.501 \\
- large & 1,210 & 0.140 & 0.178 & -0.568 & 2.286 \\
\hline Loss carry-forward in 1,000 euro (2006), Source: Simulation & & \\
All corporations & 2,105 & 10,863 & 116,098 & -472 & $5,000,000$ \\
- small & 530 & 297 & 1,949 & -368 & 33,146 \\
- medium-sized & 397 & 1,286 & 4,399 & -472 & 38,198 \\
- large & 1,178 & 18,844 & 154,730 & -412 & $5,000,000$ \\
\hline
\end{tabular}

Table B.1 is based on observations referring to the year 2006 (since 2007 data is available only for a small proportion of companies). Due to the existence of companies with AMADEUs data being available for 2007 but not 2006 (which are included in the simulation), "Number" as reported in Table B.1 is smaller than 2,236.

With regard to business activities, in accordance with the NACE classification we divide our company panel into 13 industry clusters. In this respect, our database comprises in particular companies from the manufacturing (21.82 percent), energy (13.73 percent), construction (8.22 percent), trade (16.99 percent) and services (9.21 percent) sector.

Our panel consists of about one percent of the overall population. This is borne out by comparing this panel with the number of corporations that, according to federal statistics on corporate taxation for 2006 (Destatis, 2010), are subject to corporation tax in Germany (for a detailed description of the panel structure, see Table B.4 in Section 3.5). Furthermore, the composition of our sample is not representative. In particular, large corporations are, due to stricter publication requirements applicable for these companies, covered to a larger extent in AmADEus as a whole and in our sample than small and medium-sized corporations. As a consequence we cover more than 16 percent of total income and almost five percent of existing loss carry-forwards at the end of 2006. In order to avoid possible distortions resulting from differences between the composition of our dataset and the population of all German corporations, simulation results 
are extrapolated on the basis of the German corporate income tax statistic 2006, as described in 3.5 .

Using financial accounting data instead of original tax data may bring with it possible estimation errors due to differences between financial accounting profit and taxable income. Such differences may in particular arise in the case of income from foreign permanent establishments, tax free investment income, hidden profit distributions or differences between financial and tax balance sheets. We account for these differences by deducting tax-free dividends from the financial result (see Section 3.3 for details). Adjustments taking account of other differences were not possible since relevant information is lacking. However, according to the German corporate tax statistics 2004 these remaining differences between income before loss-offset and financial accounting income amount in total to only 1.54 percent (-7.09 percent) of accounting profits (losses) for profitable (unprofitable) corporations (Destatis, 2009b). Given that these differences impact taxable income in similar manner for all considered tax scenarios, resulting estimation errors should not affect our results to any significant extent.

\subsection{Forecasting earnings and determining the effects of inter-period loss-offset}

To estimate tax revenue we apply a three-step procedure. In a first step, necessary balance sheet and income statement items are forecasted, i. e., return on assets, investment and current assets as well as depreciation, interest revenue and interest expenses. Apart from depreciation, the process of simulating all of these variables incorporates uncertainty. In a second step, we translate forecasted profits into our proxy of taxable income by applying the provisions governing inter-period loss-offset. In a final step, we calculate corporation tax payments by applying a uniform tax rate of 15 percent. Equation B.1 summarizes the applied simulation approach to determine tax payments of company $\mathrm{i}$ in year t:

$$
\begin{aligned}
T_{A X_{i, t}=} & \tau_{t} \cdot\left[\left(\text { fixed_assets }_{i, t-1} \cdot\left(1+\text { investment }_{i, t}\right) \cdot\left(1+\eta_{\text {inv }}\right)\right.\right. \\
& \left.- \text { depreciation }_{i, t-1}+\text { current_assets }_{i, t}\right) \cdot \text { ROA }_{i, t} \cdot\left(1+\eta_{\text {ort }}\right) \\
& + \text { interest_revenue }_{i, t}-\text { interest_expenses }_{i, t} \cdot\left(1+\eta_{\text {lev }}\right) \\
& \left.- \text { depreciation }_{i, t}-\text { inter_period_loss_offset }_{i, t}\right]
\end{aligned}
$$

Corporation i's tax payable in year t $\left(T A X_{i, t}\right)$ is derived by multiplying the German corporate income tax rate $(\tau)$ by corporation i's tax base with the tax base being defined as the 
EBITDA (earnings before interest, taxes, depreciation and amortization) plus taxable financial profit/loss, less depreciation and less inter-period loss-offset. However, all revenue effects reported are determined as relative changes in taxable income compared to the law currently in force. Our calculations therefore rely on the implicit assumption of constant tax rates over time instead of simulating the tax rate cut in 2008. EBITDA is determined by multiplying return on assets $(R O A)$ by the sum of fixed and current assets (excluding financial assets). ${ }^{2}$ All lagged variables (index t-1) in Equation (B.1) are taken either directly from the database (simulation for year 2007) or are the result of the previous year's simulations (simulation for years 2008 to 2012).

To forecast return on assets, investment and current assets we use AMADEUs data from 1994 to 2006 and estimate three regression equations. The resulting regression coefficients as well as company-specific means and standard deviations of residuals are then used to estimate the desired outcome variables taking account of uncertainty. That is, to forecast the three variables of interest we multiply the regression coefficients by the company- and year-specific values for the respective independent variables and add a random variable with company-specific mean and standard deviation. This procedure is repeated 3,000 times per variable, year and corporation. The derivation of investment, current assets, return on assets, the financial result and depreciation is shown in detail in the following.

Investment: Investment of company i in year t captures investment (gross of depreciation) in tangible and intangible fixed assets (excluding financial assets) and is determined on the basis of Equation B.2. Coefficients for growth of GDP $(g d p g)$ as well as return on assets in the prior year $\left(R O A_{i, t-1}\right)$ are estimated by way of an OLS regression including all sample companies with the observations referring to the pre-simulation period (1994 to 2006).

$$
\text { investment }_{i, t}=\beta_{1} \cdot g d p g_{t}+\beta_{2} \cdot R O A_{i, t-1}+\epsilon_{i, t}
$$

Table B.2 shows the estimated regression results. Both $\beta_{1}$ and $\beta_{2}$ are positive and significant at the 1 percent level, meaning that in accordance with our expectation companies invest more in years of positive general economic development and after profitable years.

\footnotetext{
${ }^{2}$ To determine fixed_assets $_{i, t}$ we deduct depreciation ${ }_{i, t-1}$ because we multiply fixed_assets $s_{i, t-1}$ by $(1+$ gross investment $)$, i.e., investment $_{t}=\left(\right.$ fixed_assets $_{t}+$ depreciation $_{t}-$ fixed_assets $\left._{t-1}\right) /$ fixed_assets $_{t-1}$. However, depreciation $_{i, t-1}$ is in this case used as an approximate value for depreciation,$t$ in order to avoid circular references.
} 
Table B.2: Regression of investment on growth of GDP and return on assets

\begin{tabular}{|c|c|}
\hline VARIABLES & \\
\hline$g d p g$ & $\begin{array}{l}0.083^{* * *} \\
(0.003)\end{array}$ \\
\hline$R O A_{i, t-1}$ & $\begin{array}{l}0.566^{* * *} \\
(0.040)\end{array}$ \\
\hline Observations & 12,644 \\
\hline R-squared & 0.171 \\
\hline \multicolumn{2}{|c|}{$\begin{array}{l}\text { Robust standard errors in parentheses } \\
\quad * * * \mathrm{p}<0.01,{ }^{* *} \mathrm{p}<0.05, * \mathrm{p}<0.1\end{array}$} \\
\hline
\end{tabular}

Current assets: Current_assets is simulated in a similar manner, based on the parameters included in Equation B.3. This equation is based on a notion that the size of current assets is subject to a general time trend (reflected by $\beta_{1}$ ) and depends on the respective change in fixed assets reflected by $\beta_{2}$. Again $\beta_{0}, \beta_{1}$ and $\beta_{2}$ are estimated on the basis of an OLS regression including all companies, with the observations referring to the pre-simulation period.

$$
\text { current_assets }_{i, t}=\beta_{0}+\beta_{1} \cdot \text { current_assets }_{i, t-1}+\beta_{2} \cdot \Delta \text { fixed_asset }_{i, t}+\epsilon_{i, t}
$$

Table B.3: Regression of current assets on prior year current assets and changes in fixed assets

\begin{tabular}{lc}
\hline VARIABLES & \\
\hline current_assets $_{i, t-1}$ & $\left(0.045^{* * *}\right.$ \\
& $0.301^{* *}$ \\
$\Delta$ fixed_assets $_{i, t}$ & $(0.132)$ \\
Constant & 1,710 \\
& $(3,642)$ \\
Observations & 15,403 \\
R-squared & 0.874 \\
\hline \multicolumn{2}{c}{ Robust standard errors in parentheses } \\
\multirow{2}{*}{$\mathrm{p}<0.01, * * \mathrm{p}<0.05, * \mathrm{p}<0.1$} \\
\hline
\end{tabular}

Return on assets: Forecasting future taxable income requires, in particular, simulation of future company earnings. In this respect three different approaches are currently a matter of debate in tax literature. Shevlin, 1990, Graham, 1996a, and Graham, 1996b, use a random-walk approach to forecast earnings, assuming that a corporation's taxable income follows a randomwalk with drift. In contrast, Graham \& Kim, 2009, presume that part of a corporation's change 
in return can be explained by the previous year's return, which leads these authors to propose application of a first-order autoregression model in order to simulate future return on assets. A third approach to forecasting earnings was introduced by Blouin et al., 2010, who apply a nonparametric approach. They assume that a corporation's future development can most accurately be predicted by considering the past development of comparable corporations.

Existing literature fails to provide a clear picture as to which of these approaches provides the most accurate forecast of taxable income. Rather, all three of these approaches feature specific advantages and disadvantages. Blouin et al., 2010, argue that the random-walk approach incorporates company-specific mean and standard deviation of changes in taxable income, both of which are held constant over time. Since taxable income is on average expected to increase over time, holding the standard deviation of future income constant should understate income volatility. In addition, previous research documented that earnings or profitability are meanreverting (see, for example, Fama \& French, 2000), which is not reflected by application of the random-walk approach.

In contrast, the non-parametric approach implicitly allows for mean reversion and assumes constant parameter values only with regard to company clusters rather than with regard to single corporations. However, Graham \& Kim, 2009, point out that the non-parametric approach ignores company-specific information, which should, in their view, be particularly relevant for forecasting earnings.

The autoregressive approach allows for mean reversion and incorporates company-specific information (at least with regard to corporations where four or more firm-year observations are available). Nevertheless, the autoregressive approach faces, similar to the random-walk approach, the problem of stationarity with regard to the single corporation.

Although there is no clear evidence regarding the quality of earnings simulated with these different approaches, some statistics in Graham \& Kim, 2009, and in Koch, 2011, indicate that the autoregressive approach performs best in terms of providing an accurate estimation of future earnings.

In light of the above considerations, we apply a modified version of the autoregressive approach, as proposed by Graham \& Kim, 2009. As described above, we follow Graham \& Kim, 2009, by applying a modified two-step AR(1) approach to forecast return on assets which is, for our purposes, defined as EBITDA/(fixed_assets + current_assets $)$. In a first step, we apply 
the following OLS regression model to estimate company-specific parameters:

$$
R O A_{i, t+1}=\mu_{i}+\rho_{i} \cdot R O A_{i, t}+\epsilon_{i, t+1}, \quad \epsilon_{i, t+1} \stackrel{i i d}{\sim} \mathcal{N}\left(0, \sigma_{i}^{2}\right)
$$

where $R O A_{i, t+1}$ is return on assets, $\mu_{i}$ is the drift and $\rho_{i}$ the autoregressive parameter. The volatility of the random shocks $\epsilon_{i, t+1}$ is represented by $\sigma_{i}^{2}$. As indicated by index i, all parameters are determined company-specifically.

In a second step, we form panels of firm-year observations (bins) and estimate bin-specific instead of company-specific parameters for the regression model specified above. To this end, bins are formed by using six income classes (two for loss-making companies and four for profitable companies) and 13 industry classes. Hence, we estimate $\mu, \rho, \epsilon$ and $\sigma$ for a total of 78 different bins. In doing so, we follow Graham \& Kim, 2009, in using the system GMM estimator introduced by Blundell \& Bond, 1998, instead of a simple OLS regression. In order to preserve the microanalytic character of our simulation as far as possible, the second step approach is (only) applied when at least one of the following conditions is met for the company-specific regression: $\left|\rho_{i}\right|>$ $1, \sigma_{i}^{2}>1$ or $\mu_{i} /\left(1-\rho_{i}\right)>0.6$.

Financial result: Interest_expenses is calculated by multiplying an interest expense rate by the balance sheet total. The interest expense rate is a normally distributed random variable with company-specific mean and standard deviation, based on the proportion of financial expenses to the balance sheet total in the Amadeus data from 1994 to 2007. This rate reflects both the company-specific interest rate and the company leverage. Equations B.5 and B.6 show the respective calculations.

$$
\begin{gathered}
\text { interest_expenses }_{i, t}=\text { total_asset }_{i, t} \cdot \text { int_exp_rate }_{i} \\
\text { int_exp_rate }_{i}=\varnothing_{94-07}\left(\text { interest_expenses }_{i} / \text { total_asset }_{i}\right)
\end{gathered}
$$

Similarly, interest_revenue is derived by applying an interest revenue rate to the balance sheet total. We account for differences between financial and taxable income by deducting 95 percent of dividends from financial revenue before calculating the interest revenue rate. The estimation of interest_revenue is shown by Equations B.7 and B.8.

$$
\text { interest_revenue }_{i, t}=\text { total_assets }_{i, t} \cdot \text { int_rev_rate }_{i}
$$




$$
\text { int_rev_rate }_{i}=\varnothing_{94-07}\left(\left(\text { interest_revenue }_{i}-0.95 \cdot \text { div }_{i}\right) / \text { total_assets }_{i}\right)
$$

Depreciation: The value of depreciation is calculated by multiplying fixed assets (excluding financial assets) by a company-specific depreciation rate (see Equation B.9). These rates are calculated as the mean of the depreciation rates in 2006 and 2007 as shown by Equation B.10.

$$
\begin{array}{r}
\text { depreciation }_{i, t}=\left(\text { fixed_asset }_{i, t}-\text { fin_fixed_asset }_{i, t}\right) \cdot \text { dep_rate }_{i} \\
\text { dep_rate }_{i}=\varnothing_{06,07}\left(\text { depreciation }_{i} /\left(\text { fixed_assets }_{i}-\text { fin_fixed_asset }_{i}\right)\right)
\end{array}
$$

Inter-period loss-offset: To estimate the value of inter_period_loss_offset we need to determine existing loss carry-forwards at the beginning of the simulation period (December 31, 2006) and to simulate the application of loss-offset provisions from 2007 to 2012 (both under the law currently in force and under the different reform scenarios). In order to determine existing amounts of tax loss carry-forwards as of year 2006 we rely on accounting profits for the years 1994 to 2006 taken from Amadeus after deduction of received dividends. They are estimated according to the following equations:

$$
\begin{gathered}
\operatorname{inc}_{i, t}=\max \left(i n c b o_{i, t}-\min \left(l c f_{i, t-1} ; l i m i t\right) ; \min \left(l c b_{t} ; 0\right)\right) \\
l c f_{i, t}=l c f_{i, t-1}+i n c_{i, t}-i n c b o_{i, t}
\end{gathered}
$$

where inc is taxable income after loss-offset (excluding tax-deductible dividends), lcf are existing loss carry-forwards and incbo is an approximate value of taxable income before loss-offset (that is profit/loss for period minus taxation, minus estimated tax-free dividends). The variable limit refers to minimum taxation and is calculated as follows: limit $=\max (0 ; 1,000,000+$ $0.6 \cdot\left(\right.$ incbo $\left.\left._{i, t}-1,000,000\right)\right) . l c b_{t}$ is the loss carry-back available in year $\mathrm{t}$ and is calculated as $\max \left(-i n c_{i, t-1} ;-511,000\right)$. Existing tax losses in 1994 are assumed to be zero. As an alternative approach to determining loss carry-forward as of 2006, we could rely on the value of negative reserves as reported in the accounting financial statements. Our calculations, however, reveal that this would lead to a larger understatement of loss carry-forward, most probably due to the effect of capital injections after loss periods. Reister et al., 2008, assume tax loss carry-forwards to exist in the case of zero tax payments. This approach, however, was not applicable for our purposes since tax expense as reported in Amadeus is not subdivided into tax payments and deferred tax expense. 
The same equations are used to estimate inter-period loss-offset and taxable income under the law currently in force from 2007 to 2012. To estimate taxable income under the reform scenarios mentioned above we apply the following equations:

(a) abolition of minimum taxation

$$
i n c_{i, t}=\max \left(i n c b o_{i, t}-l c f_{i, t-1} ; \min \left(l c b_{i, t} ; 0\right)\right)
$$

(b) abolition of loss carry-back

$$
i n c_{i, t}=\max \left(i n c b o_{i, t}-\min \left(l c f_{i, t-1} ; \text { limit }\right) ; 0\right)
$$

(c) abolition of minimum taxation and loss carry-back

$$
i n c_{i, t}=\max \left(i n c b o_{i, t}-l c f_{i, t-1} ; 0\right)
$$

The variables $l i m i t, l c b$ and $l c f$ are calculated as shown above. In the case where loss carryforward is limited to seven years, losses incurred in each year are extrapolated in separate baskets, whereby old carry-forwards are used first.

In order to evaluate the accuracy of the applied forecasting procedure we use the DAFNE database which comprises corporate income tax payments for German corporations. The database, however, includes tax payments for only approximately 100 of the simulated corporations in the years 2007 to 2009 (in later years the sample is further reduced). Beyond checking for accuracy the database does not provide sufficient back-up information to allow for calibration of the model. We, therefore, compare simulated and real tax payments for these 100 corporations. The results are shown in Tables B.9 and B.10 of the Appendix. These results indicate that our simulation procedure produces an adequate forecast of corporate tax payments both with regard to the average value and the correlation with actual tax payments.

\subsection{Modeling behavioral responses}

Over recent decades, both theoretical and empirical literature has provided manifold insight into the tax impact on various kinds of company decisions. It is therefore fair to assume that in addition to first round effects on tax revenue and tax bill immediately resulting from the change in tax law, also responses in company behavior may impact tax expenses as a consequence 
of these reforms. In order to determine possible revenue consequences of such responses, we incorporate three different elasticities by way of a scenario analysis, including the elasticity of (i) capital structure, (ii) investments and (iii) operative risk-taking. Consideration of these elasticities is, for reasons of simplicity, restricted to the scenario where the abolition of minimum taxation and the loss carry-back option, as well as the limitation of loss carry-forward to a period of seven years, are considered as a simultaneous tax reform. Modeled behavioral responses therefore need to reflect enhanced inter-period loss-offset possibilities.

The relation between taxes and capital structure has been analyzed in a number of empirical studies. The majority of these studies, however, focuses on the impact of the tax rate on financing decisions (see Feld et al., 2011, for a meta-study), whereas loss-offset provisions and/or existing amounts of loss carry-forward are only considered in few cases. Theoretical literature, however, suggests that the existence of a fiscal loss carry-forward as well as other non-debt tax shields (e. g. depreciation) reduces the tax incentive for debt finance (see DeAngelo \& Masulis, 1980; for empirical evidence see MacKie-Mason, 1990, and Dhaliwal et al., 1992). Following this notion, companies are expected to reduce (increase) debt finance as a response to more (less) restrictive loss-offset provisions.

Other studies take account of loss-offset regulations when calculating marginal tax rates. According to Graham, 1996a, "the marginal tax rate is defined as the present value of current and expected future taxes paid on an additional dollar of income earned today". In the case of more generous loss-offset provisions this additional dollar of income (which may be interpreted as a one dollar smaller loss) becomes tax effective earlier and therefore leads to a higher marginal tax rate. Applying this definition to explain corporate capital structure decisions, Graham et al., 1998, find a positive relation between debt and the marginal tax rate.

In accordance with these studies, we therefore assume that relaxed loss-offset provisions lead to higher marginal tax rates and thus to an increasing incentive to debt financing. Given the unavailability of empirical studies analyzing directly the impact of changed loss-offset provisions on company debt-financing, we therefore include positive elasticities between 1 and 5 percent in our scenario analysis. In order to incorporate these elasticities, we adjust the mean of the normally distributed variable simulating interest expenses upwards (shown by the leverage elasticity $\eta_{l e v}$ in Equation B.1).

The impact of tax considerations on investment decisions has been analyzed both in theoretical and empirical studies. Various empirical studies show that investments are negatively related to the statutory tax rate (for example Hartman, 1985, or Bartik, 1985) and the effective average tax 
rate (for example Devereux \& Griffith, 1998, or Buettner \& Ruf, 2007). To our knowledge the only study directly addressing the impact of loss-offset provisions on investment behavior is Dreßler \& Overesch, 2012. They provide empirical evidence that investments of subsidiaries decrease significantly if loss carry-forward is restricted in terms of time, particularly if these subsidiaries operate in risky industries. Assuming a company operating in an industry associated with an average operative risk the respective semi-elasticity amounts to some -1.4 percent. We follow these empirical findings by assuming that improved loss-offset provisions lead to higher levels of investment. Also for the investment elasticity ( $\eta_{i n v}$ in Equation B.1) we consider different scenarios by increasing investments between 1 and 5 percent.

The relation between fiscal loss-compensation rules and the level of risk-taking has been intensely examined in the literature based on theoretical models. Seminal is the article by Domar \& Musgrave, 1944, who analyze the decision between a risky and a riskless investment based on a one-period model for a risk-averse investor. They arrive at the general conclusion that the government's participation in investment losses impacts the readiness to risk-taking. Compared to a world without taxes the direction of this impact is decisively dependent on the tax rate and the restrictions in loss compensation. More restrictive loss compensation rules should, however, lead ceteris paribus to less risk-taking. Continuative models integrate in particular differing risk definitions as well as formal descriptions of risk utility and risk aversion (see, for example, Tobin, 1958; Mossin, 1968; Stiglitz, 1969, or Haegert \& Kramm, 1975). Relying on more general assumptions, these examinations confirm the vital results by Domar \& Musgrave, 1944, in the case of complete loss compensation.

Koch \& Prassel, 2011, provide empirical evidence for the impact of changes in the fiscal loss compensation rules on the readiness to risk-taking of corporations. Their results show that large corporations in Belgium increased the level of operative risk significantly (captured by the company-specific interest rate) as a response to the abolition of the minimum taxation rule in 1998. The respective semi-elasticity amounts to 3 percent. Taking into consideration that the abolition of minimum taxation affects only some of the companies in our sample, we account for this impact in our simulations by increasing the absolute value of the simulated corporations' operating return between 0.4 and 2 percent ( $\eta_{\text {ort }}$ in Equation B.1). This procedure should, on average, yield the same results as increasing both mean and standard deviation of return on assets prior to the simulation procedure. 


\subsection{Extrapolation procedure}

In order to account for structural differences between the data set applied in the present study and the overall population of German corporations, we extrapolate resulting tax revenue based on information taken from the German corporate income tax statistics 2006 (Destatis, 2010). These statistics, however, offer information with only a limited degree of detail, i. e., they provide at best statistics on the number of corporations falling into a specific income class. Therefore, thirteen different income classes are distinguished. Table B.4 shows with respect to these different classes of income the number of corporations for the overall population and our sample.

Table B.4: Data coverage in 2006

\begin{tabular}{llrrr}
\hline \multicolumn{1}{c}{$\begin{array}{c}\text { Income } \\
\text { class }\end{array}$} & $\begin{array}{r}\text { Taxpayer } \\
\text { Destatis }\end{array}$ & $\begin{array}{r}\text { Taxpayer } \\
\text { AmADEus }\end{array}$ & $\begin{array}{r}\text { Coverage } \\
\text { in percent }\end{array}$ \\
\hline Class $1=(-\infty ;-5$ million $]$ & 1,274 & 120 & 9.42 \\
Class $2=(-5$ million; -1 million $]$ & 4,197 & 112 & 2.67 \\
Class $3=(-1$ million; $-100,000]$ & 27,939 & 106 & 0.38 \\
Class $4=(-100,000 ;-50,000]$ & 22,101 & 31 & 0.14 \\
Class $5=(-50,000 ;-10,000]$ & 84,727 & 34 & 0.04 \\
Class $6=(-10,000 ; 0)$ & 151,568 & 19 & 0.01 \\
Class $7=[0]$ & 20,723 & 6 & 0.03 \\
Class $8=(0 ; 10,000]$ & 260,376 & 59 & 0.02 \\
Class $9=(10,000 ; 50,000]$ & 166,997 & 134 & 0.08 \\
Class $10=(50,000 ; 100,000]$ & 52,651 & 101 & 0.19 \\
Class $11=(100,000 ; 1$ million $]$ & 80,715 & 511 & 0.63 \\
Class $12=(1$ million; 5 million $]$ & 12,035 & 516 & 4.29 \\
Class $13=[5$ million; $\infty)$ & 3,490 & 487 & 13.95 \\
\hline Total & & 888,793 & 2,236 & 0.25 \\
\hline
\end{tabular}

For purposes of extrapolating our sample results to the total business population (as included in the German corporate tax statistics) a two step procedure is applied. In a first step we calculate the proportion of corporations in the sample in a specific income class to the total population of corporations in that class (see Table B.4). Based on this, we weight all corporations in the sample with the inverse of that proportion. Applied proportions are determined with reference to the year 2006 and are held constant throughout the whole simulation period.

Because we calculated taxes payable 3,000 times for each corporation and year the extrapolation procedure leads to 3,000 varying results for tax revenue. To mitigate the impact of influential outliers the median of the 3,000 simulation runs is used as our final result. 


\section{Results}

\subsection{First-round effects}

Table B.5 presents the revenue effects resulting, as first-round effects, immediately from (1) the abolition of minimum taxation, (2) the limitation of loss carry-forward to seven years, and (3) the abolition of loss carry-back. In addition to the three single reform scenarios column four shows the effects of all three reform scenarios implemented simultaneously. In all cases the reference scenario is the law currently in force and revenue effects reported refer to relative changes in the tax base (we therefore implicitly assume constant tax rates). Column 5 shows absolute revenue effects in million $€$, applying a constant tax rate of 15 percent.

Table B.5: Revenue effects without considering behavioral responses

\begin{tabular}{lccccc}
\hline & $\begin{array}{c}\text { Abolition of } \\
\text { minimum } \\
\text { taxation }\end{array}$ & $\begin{array}{c}\text { Limiting } \\
\text { lcf to } \\
\text { seven years }\end{array}$ & $\begin{array}{c}\text { Abolition } \\
\text { of loss } \\
\text { carry-back }\end{array}$ & $\begin{array}{c}\text { All reform } \\
\text { scenarios }\end{array}$ & $\begin{array}{c}\text { Absolute } \\
\text { revenue } \\
\text { effects }\end{array}$ \\
\hline 2007 & -0.0440 & 0.0019 & 0.0667 & 0.0269 & 370.239 \\
2008 & -0.0324 & 0.0009 & 0.0399 & 0.0072 & 114.488 \\
2009 & -0.1653 & 0.0004 & 0.1025 & -0.0785 & -563.173 \\
2010 & -0.0402 & 0.0008 & -0.0240 & -0.0636 & -766.229 \\
2011 & -0.0076 & 0.0025 & -0.0006 & -0.0036 & na \\
2012 & -0.0039 & 0.0026 & 0.0027 & 0.0001 & na \\
\hline Overall & -0.0252 & 0.0020 & 0.0157 & -0.0085 & -844.676 \\
Mean & -0.0489 & 0.0015 & 0.0312 & -0.0186 & -211.169 \\
Lcf 2012 & -0.0620 & -0.2345 & 0.0175 & -0.2604 & na \\
\hline
\end{tabular}

Lcf 2012 refers to the relative changes in existing loss carry-forwards at the end of 2012 as compared to the law currently in force.

As one would anticipate, the abolition of minimum taxation reduces tax revenue over the six-year simulation period, whereas both limiting the loss carry-forward period and abolishing loss carry-back increase the tax budget. The abolition of minimum taxation has the largest effect (overall effect -2.52 percent, average effect -4.89 percent), whereas the effect of the loss carryforward limitation to seven years is only minimal (overall effect +0.20 percent, average effect +0.15 percent). Also the cancellation of loss carry-back turns out to be of smaller impact (overall effect +1.57 percent, average effect +3.12 percent) than the abolition of minimum taxation, which may be attributable to the fact that loss carry-back was formerly limited to the amount of $€ 511,500$. The effect of implementing all reform scenarios simultaneously has an overall impact of -0.85 percent, with the tax revenue being increased in three years and decreased in three years of simulation. If multiplied by the overall corporate income tax revenue of the years 
2007 to 2010 the relative effect translates into an absolute revenue change of less than $€ 1$ billion. In addition, changes would occur with regard to trade tax. Since an accurate simulation of trade tax revenue effects would require determination of an additional tax base as well as simulation of alternative inter-period loss-offset regulations for the law currently in force we restricted our analysis to the corporate income tax.

When interpreting the results, one should take into account the fact that revenue effects resulting from changes to the provisions governing inter-period loss-offset may be of a temporary nature and thus reverse in future years. This possible reverse effect is indicated by the reduced volume of loss carry-forwards prevailing at the end of the simulation period as shown in the bottom line of Table B.5. The extent to which these smaller loss carry-forwards actually become tax effective depends on the development of future company profits. Our results indicate that in the case of subsequent years with positive economic development (2010 to 2012) the combined effect of the tax reform is reduced in size (2010 to 2011) or even reversed (2012).

With regard to the three separate reform scenarios, the abolition of loss carry-back similarly leads to both positive (years 2007 to 2009 and 2012) and negative (years 2010 and 2011) revenue effects. This is, again, due to the fact that loss-offset provisions (except those limiting the loss carry-forward period and therefore leading to a cut of existing loss carry-forwards) may exercise pure timing effects. Whereas tax revenue increases in the first periods after the reform due to the limited possibility to carry losses back in former periods, it may decrease in later periods because losses already utilized under the law currently in force can be offset in these periods under the reform scenario. The restriction of loss carry-forward to seven years would in contrast exercise a permanent revenue effect if existing loss carry-forwards could be utilized under the law currently in force after expiration of the seven-year loss carry-forward period. According to our estimations this restriction would lead to a reduction of loss carry-forwards at the end of the simulation period by 23.45 percent. However, only 1.72 percent of these losses could be utilized under prevailing tax law, which explains the small revenue effect of this reform scenario.

The distribution of revenue increases and decreases over time is determined in particular by the development of simulated profits and losses. In accordance with the overall economic development, we simulate the largest amounts of losses in the years 2008 and 2009, implying that both the abolition of minimum taxation and loss carry-back exercise the largest effect in 2009. 


\subsection{Size-specific effects}

Table B.6 displays revenue effects for three different classes of company size, hereby defining corporations with a balance sheet total of $€ 4,840,000$ and less as being small, corporations with a balance sheet total of more than $€ 19,250,000$ as being large, and all companies with a balance sheet total in between the two numbers as being medium-sized enterprises. Reported revenue effects refer to the simultaneous implementation of all three reform scenarios, whereby, again, the law currently in force serves as a point of reference. Since it is the intention of this analysis to compare changes in tax expenses for different classes of companies rather than to predict overall revenue effects, we refer here to the original rather than to the extrapolated data sample.

Table B.6: Size-specific revenue effects without considering behavioral responses

\begin{tabular}{lcccc}
\hline & $\begin{array}{c}\text { Small } \\
\text { enterprises }\end{array}$ & $\begin{array}{c}\text { Medium } \\
\text { enterprises }\end{array}$ & $\begin{array}{c}\text { Large } \\
\text { enterprises }\end{array}$ & $\begin{array}{c}\text { All } \\
\text { enterprises }\end{array}$ \\
\hline 2007 & 0.5644 & 0.0345 & -0.0519 & -0.0485 \\
2008 & 0.1915 & 0.2602 & -0.0299 & -0.0291 \\
2009 & -0.1050 & -0.2211 & -0.1173 & -0.1190 \\
2010 & -0.0247 & 0.0046 & -0.0255 & -0.0263 \\
2011 & -0.0130 & -0.0209 & -0.0022 & -0.0032 \\
2012 & -0.0125 & 0.0004 & 0.0014 & 0.0016 \\
\hline Mean & 0.1001 & 0.0096 & -0.0376 & -0.0374 \\
\hline
\end{tabular}

The results reported in Table B.6 are in line with theoretical expectations. Regarding largescale companies the abolition of minimum taxation leads to a decrease of the tax base, whereas the cancellation of loss carry-back seems to have only minor effect. As a consequence, the overall revenue effect is therefore negative for this group of companies (-3.76 percent). In contrast, the effect of the abolition of loss carry-back increases when looking at small and medium-sized enterprises. This means that tax revenue increases, as a consequence of the tax reform as a whole, by about 0.96 percent with regard to medium-sized and about 10.01 percent with regard to small corporations. Waiving minimum taxation exercises for these companies no substantial influence on the development of taxable income since small and medium-sized enterprises are, because of the basic amount of $€ 1$ million, in many cases not affected by this regulation. It becomes apparent that the analyzed reform would benefit large scale enterprises at the cost of medium and, in particular, small companies.

With regard to large corporations the positive revenue effect in 2012 can, again, be traced back to timing differences (because of improved loss-offset provisions more losses are offset in earlier years and therefore fewer losses are left to be set off in later years, and tax revenue increases 
as compared to the law currently in force). A similar argumentation applies with regard to small and medium-sized companies. In the years directly following the reform, tax revenue from these companies increases because they suffer from the abolition of loss carry-back. However, tax revenue falls in later years because losses which were already set off under the law currently in force can now be set off under the reform scenario.

\subsection{Industry-specific effects}

Table B.7 presents an industry-breakdown of the revenue effects including both the abolition of minimum taxation, the limitation of the loss carry-forward to seven years, and the abolition of loss carry-back. Again, the reference scenario is the law currently in force and the results refer to the original rather than to the extrapolated sample.

Table B.7: Industry-specific revenue effects without considering behavioral responses

\begin{tabular}{lcccrrr}
\hline & $\begin{array}{c}\text { Manufac- } \\
\text { turing }\end{array}$ & Energy & $\begin{array}{c}\text { Con- } \\
\text { struction }\end{array}$ & Trade & Services & $\begin{array}{c}\text { All in- } \\
\text { dustries }\end{array}$ \\
\hline 2007 & -0.0388 & 0.0003 & -0.0049 & -0.0213 & -0.0286 & -0.0485 \\
2008 & 0.0058 & -0.0056 & -0.0044 & 0.0515 & 0.0221 & -0.0291 \\
2009 & -0.1752 & -0.0097 & -0.0109 & -0.1915 & -0.1152 & -0.1190 \\
2010 & -0.0378 & -0.0012 & -0.0453 & -0.0262 & -0.0042 & -0.0263 \\
2011 & 0.0082 & -0.0011 & -0.0052 & -0.0190 & 0.0035 & -0.0032 \\
2012 & 0.0060 & -0.0004 & -0.0303 & -0.0017 & -0.0053 & 0.0016 \\
\hline Mean & -0.0386 & -0.0030 & -0.0168 & -0.0347 & -0.0213 & -0.0374 \\
\hline
\end{tabular}

Table B.7 shows that the considered reform scenario leads, on average, to a decrease in tax revenue in all reported industries. The industries benefiting most from the analyzed reform scenario are the manufacturing (-3.86 percent) and trade (-3.47 percent) industry. The energy sector faces the smallest benefits $(-0.30$ percent), whereas the effects in the construction $(-1.68$ percent) and in the services (-2.13 percent) industry lie in between. These findings may be traced back to the respective industry characteristics, leading to a different relevance of the single aspects of the considered reform. Whereas the energy industry is characterized by low volatility (because energy is also needed in times of crises) it is representative for the construction industry that a large proportion of long-term contracts is concluded leading to a lagged effect of an economic downturn.

In addition, results reported in Table B.7 imply that the considered tax reform has a positive impact on tax revenue when looking at the manufacturing ( +0.58 percent $)$, trade $(+5.15$ percent) and services $(+2.21$ percent) industry in 2008. This suggests that these industries suffer above- 
average losses in 2008 leading to a minor relevance of the abolition of minimum taxation and to a higher relevance of the cancellation of the loss carry-back in this year. Indeed our simulation procedure yields the highest proportion of unprofitable companies in these industries.

The small but positive revenue effect in the energy sector in 2007 indicates that this industry suffers more from the abolition of loss carry-back in this year than it benefits from the abolition of minimum taxation. The positive revenue effects after 2010 in the manufacturing and the service sector are due to the fact that, as compared to the law currently in force, more losses were utilized in earlier years, which therefore cannot be used in later years.

\subsection{Considering behavioral responses}

In order to consider behavioral responses, we incorporate three elasticities, namely investment elasticity, the elasticity of capital structure and the risk-taking elasticity. As described in Section 3.4 we use these elasticities in order to permanently adjust specific company parameters. All three elasticities are (separately) applied to the scenario where both the abolition of minimum taxation and loss carry-back option, as well as the limitation of the deductibility of losses carried forward to a period of seven years, are simulated. Table B.8 shows relative changes in the tax base for the respective elasticities. All changes represent total changes over the whole simulation period (2007 to 2012). Again, the law currently in force serves as a reference.

Table B.8: Total relative changes in tax base from 2007 to 2012

\begin{tabular}{cccccc}
\hline$\eta_{\text {lev }}$ & $\begin{array}{c}\text { Change in } \\
\text { tax base }\end{array}$ & $\eta_{\text {inv }}$ & $\begin{array}{c}\text { Change in } \\
\text { tax base }\end{array}$ & $\eta_{\text {ort }}$ & $\begin{array}{c}\text { Change in } \\
\text { tax base }\end{array}$ \\
\hline $1.00 \%$ & -0.0105 & $1.00 \%$ & 0.0035 & $0.40 \%$ & -0.0000 \\
$2.00 \%$ & -0.0068 & $2.00 \%$ & 0.0199 & $0.80 \%$ & 0.0010 \\
$3.00 \%$ & -0.0101 & $3.00 \%$ & 0.0312 & $1.20 \%$ & 0.0007 \\
$4.00 \%$ & -0.0111 & $4.00 \%$ & 0.0425 & $1.60 \%$ & 0.0059 \\
$5.00 \%$ & -0.0179 & $5.00 \%$ & 0.0618 & $2.00 \%$ & 0.0096 \\
\hline
\end{tabular}

Depending on the applied elasticities revenue effects are between -0.68 percent and -1.79 percent (capital structure elasticity $\left.{ }^{3}\right),+0.35$ and +6.18 percent (investment elasticity) and approximately 0 and +0.96 percent (elasticity of operative risk-taking). Whereas an increase of investment has the consequence of raising profits and therefore taxable income, higher debt to equity ratios have the consequence of lowering taxable income because of higher interest expenses. The strong increase in revenue effects with regard to investment elasticity should be

\footnotetext{
${ }^{3}$ When interpreting the results for capital structure elasticity we do not consider that the resulting interest payments correspondingly increase tax payments of the recipient. In the case that the recipient is subject to German corporate income tax this should result in an overstatement of the estimated revenue effect.
} 
due to exponential effects, given that the respective elasticities are applied in every year of the simulation period. That is, if the elasticity is 4 percent, the increase in investment amounts to 4 percent every year between 2007 and 2012 .

As it becomes apparent from Table B.8 higher operative risk taking generally leads to higher taxable income and therefore to higher tax revenue which may be traced back to two different circumstances. First of all, in cases where a higher operative risk results in a higher operating return it leads, by definition, to higher profits. Secondly, whereas all positive changes in operating return through a higher operative risk are fully reflected in taxable income, negative changes are not completely included in the tax base since not all losses become fully deductible. Altogether, the results reported in Table B.8 imply that revenue effects may actually reverse if behavioral responses are considered and that disregarding these effects may cause severe estimation errors.

Since the effects estimated for the considered elasticities of capital structure and operative risk taking differ to only small extent and are small in amount, the overall reform effect with company responses being considered should depend particularly on the investment elasticity. Based on the results reported in Table B.8 it can be assumed that the reform would turn out to be revenue neutral for an investment elasticity between one and two percent. The assumption of an elasticity in this range appears to be realistic given that Dreßler \& Overesch, 2012, estimate an investment semi-elasticity of -1.4 percent for a restriction of loss carry-forward.

\section{Conclusions}

The focus of this paper is on determining the revenue consequences of reforming the provisions governing inter-period loss-offset with respect to tax bill and tax budget. As has been shown above, we have developed a simulation approach which is capable of (1) analyzing the direct effects of policy reforms on the level of micro-units (i. e., the corporations), (2) extrapolating the company data over time, and (3) considering behavioral responses by way of a scenario analysis. We have analyzed the effects of three reform options, namely the abolition of minimum taxation, the limitation of loss carry-forwards to seven years, and the cancellation of loss carryback. Thereby the law currently in force has served as a reference for measuring changes in tax revenue.

In a first step revenue effects of the three reform options have been analyzed without considering behavioral responses. In doing so we find that abolition of the minimum taxation provision would reduce tax revenue by some two percent on average, if at the same time the loss carry-back 
option is canceled and a seven-year limit to loss carry-forward is introduced. A second analysis focused on size-specific effects on tax expenses. To this end the corporations included in our sample have been divided into three different size classes. Our analysis reveals that the tax reform considered would benefit large-scale enterprises at the expense of small and medium-sized corporations. In addition, we report industry-specific revenue effects of the considered reform option. Here, we find that especially industries being affected only to small extent by the overall economic development are subject to a smaller change in tax expenses than industries with a high dependence on economic circumstances.

Lastly, we have analyzed revenue effects of the reform option taking behavioral responses into account. We have included investment elasticity, the elasticity of capital structure and the elasticity of operative risk. Such responses may reduce or even invert the initial revenuereducing effect of the reform if companies raise their willingness for risk-taking or the amount of investment. 


\section{Appendix - Evaluation of the model}

Table B.9: Evaluation of the model (including outliers)

\begin{tabular}{lccc}
\hline & 2007 & 2008 & 2009 \\
\hline Observations & 109 & 111 & 83 \\
Mean of corporate tax payments & & & \\
$\quad$ Micro-simulation model & 1738.79 & 2000.16 & 226.88 \\
$\quad$ DAFNE Database & 1148.17 & 1886.16 & 1183.88 \\
Variation coefficient of corporate tax payments & & & \\
$\quad$ Micro-simulation model & 2.44 & 6.64 & 4.44 \\
$\quad$ DAFNE Database & 2.94 & 6.81 & 0 \\
Median of corporate tax payments & 191 & & 43 \\
$\quad$ Micro-simulation model & 95 & 52 & \\
$\quad$ DAFNE Database & 0.53 & 0.96 & 0.58 \\
Correlation of simulated and actual tax payments & & \\
\end{tabular}

Table B.10: Evaluation of the model (without outliers)

\begin{tabular}{lccc}
\hline & 2007 & 2008 & 2009 \\
\hline $\begin{array}{l}\text { Observations } \\
\text { Mean of corporate tax payments }\end{array}$ & 108 & 111 & 82 \\
$\quad$ Micro-simulation model & 1466.21 & 2000.16 & 190.10 \\
$\quad$ DAFNE Database & 1153.15 & 1886.16 & 696.44 \\
Variation coefficient of corporate tax payments & & & \\
$\quad$ Micro-simulation model & 2.16 & 6.64 & 3.73 \\
$\quad$ DAFNE Database & 2.94 & 6.81 & 2.58 \\
Median of corporate tax payments & 190 & 0 & 0 \\
$\quad$ Micro-simulation model & 95 & 52 & 42 \\
$\quad$ DAFNe Database & & & \\
Correlation of simulated and actual tax payments & 0.73 & 0.96 & 0.54 \\
\hline
\end{tabular}




\section{ASSERT - Assessing the effects of reforms in taxation - a micro-simulation approach}

Together with Andreas Oestreicher, Reinald Koch and Stefan Hohls

Working Paper, Georg-August-Universität Göttingen

Available under:

http://www.uni-goettingen.de/de/working-papers--discussion-papers/135729.html 


\section{Introduction}

In light of a government's need to balance its budget, it is important for legislators to be able to ex ante assess the potential consequences of prospective tax reforms on tax revenue. The same holds for individual and corporate taxpayers with regard to the impact of such reforms on their tax burden. In both cases, micro-simulation models can provide appropriate answers. Micro-simulation models have been used for many years to assess the consequences of possible tax reforms with regard to housholds' tax burden. In more recent years, such models have increasingly been employed with respect to company taxation (Oestreicher \& Koch, 2011, Bach et al., 2008, Reister et al., 2008, Creedy \& Gemmell, 2007, Oropallo \& Parisi, 2005, Castellucci et al., 2003). Existing micro-simulation models for the corporate sector usually refer to a single country and a specific period in the past and are designed to capture as much detail as possible about the specific country's tax rules ("standard approach"). To determine tax liability, such models usually take as their starting point the pre-tax earnings reported in financial statements. These earnings are translated into estimators for taxable income both under prevailing tax law and under a possible reform scenario. The resulting differences in tax burdens then serve as an indicator of the impact of a tax reform.

In addition to having advantages, this standard approach for company micro-simulation has certain shortcomings. Given the increasing complexity of company tax legislation, limiting the model to a single country allows for a detailed representation of that country's tax law. However, such a single-country approach disregards the importance of cross-border business structures, which are of increasing relevance for company decisions. In contrast to the standard approach, we therefore examine not only the consequences of tax reforms from the perspective of a single country but also the cross-border effects of tax reforms. Assuming that multinational groups respond to changes in tax law when they allocate investments and tax bases, tax reforms in one member state are expected to have knock-on effects on tax revenue in all other member states. These indirect inter-nation effects can best be incorporated into a model that captures the taxation of important trading-partner states. To this end, in the current version of our model, we incorporate 19 countries that belong to the European single market.

Similarly, estimating tax liability directly, based on financial statements for a specific period in the past, also has drawbacks. Although an advantage of this backward-looking method is that it is based on realized company data and therefore avoids any measurement error that may result from forecasting future company performance, it relies on the questionable assumption 
that the future effects of tax reforms correspond to the effects that would have resulted had the reform been implemented in the past. We, therefore, employ a forward-looking method that uses forecasting techniques to derive a fair representation of future company performance. This outlook appears to us to offer a superior basis for assessing the potential effects of future tax reforms. Additionally, forward-looking methods facilitate the incorporation of behavioral responses to tax reforms, since they do not have to be incorporated in already realized data.

Based on these considerations, our micro-simulation model, ASSERT, is designed to capture the taxation of corporations in 19 European member states. It is intended to evaluate the impact of corporate tax reforms proposed at the EU level and to take into account the indirect internation effects of domestic tax reforms. ASSERT takes into account only the key tax regulations with respect to the tax base determination, i. e., tax depreciation, tax treatment of corporate dividends and inter-period and intra-group loss-offsets. Furthermore, in our model, tax liability is determined based on forecasts of future earnings, enabling us to predict changes in future tax revenue and to incorporate business responses to tax reforms.

\section{General approach and underlying data}

\subsection{General approach}

The micro-simulation model ASSERT is built upon five integrated modules covering (1) the simulation of future company development, (2) the possible behavioral responses of companies, (3) the determination of tax liability, (4) the derivation of items for next year's simulation and (5) the assessment of the possible tax outcomes for fiscal authorities and businesses. Our starting point is a set of financial company data that are taken from databases provided by the service company Bureau van Dijk. Application of comprehensive data preparation and data transformation procedures, which are described in detail in Annex 1, yields the dataset that is described in Section C.2.2.

The first module of ASSERT translates the historical data into a forecast of future company development over a period of four years. The forecast is primarily based on a non-parametric simulation approach following the procedure applied by Blouin et al., 2010. The second module accounts for possible behavioral responses (this module has yet to be finalized), and the third module translates the forecasted earnings into tax liability. To this end, our model is capable of deriving tax liability both under the law that is currently in force and under possible reform scenarios. In the fourth model, items necessary for the next year's simulation are determined. 
Finally, the fifth module is designed to derive aggregate outcomes from the perspectives of both businesses and the fiscal authorities. The module computes company tax burdens and extrapolates the possible consequences for tax revenue.

Figure C.1 outlines the basic structure of our model. The functionality of the different modules is described in detail in the following sections.

Figure C.1: Structure of the micro-simulation model ASSERT

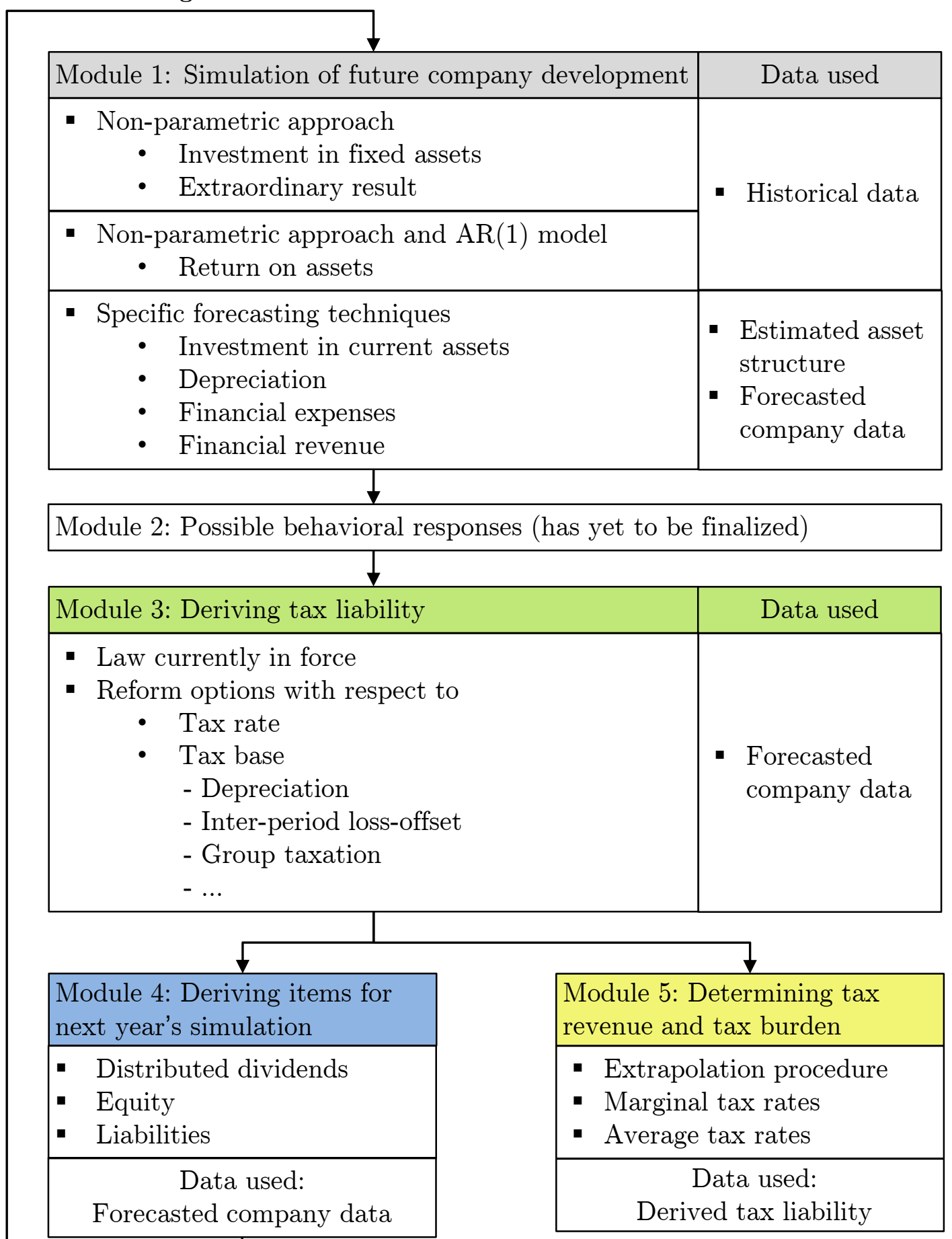

Source: Own diagram. 


\subsection{Data requirements and structure of the data}

The objectives of our micro-simulation model set out above imply that we have certain data requirements, which are outlined briefly in the current section. Ideally, we would model ASSERT to draw on a European panel of company micro-data that includes original tax data. This is not feasible, however, since access to confidential tax data is strongly restricted in most member states. Therefore, we rely on the information that is contained in publicly available, unconsolidated financial statements for European corporations, which is made available by Bureau van Dijk.

The simulation procedure requires data for (a) companies for which the forecasting procedure is carried out and (b) comparable enterprises whose past development is applied for forecasting purposes. Information on the companies that are selected for the simulation process is required for one or two years prior to the simulation period, depending on the variable. In particular, the following items of information are required and taken up in our dataset:

(1) Industry sector classification: Information is necessary to calculate certain undisclosed data, which we assume to depend on the industry sector, e. g., the asset structure.

(2) Shareholding information and group structure: Determining dividend flows, which are tax exempt in most countries, requires information on direct shareholdings. Knowledge of corporate group structures is necessary, in particular, to take into account the tax consequences of group taxation regimes.

(3) Structure of assets: An accurate estimation of tax depreciation necessitates detailed knowledge of the structure of assets, with respect to both the type of asset and the year of acquisition. To this end, our dataset distinguishes between intangible fixed assets (with the subordinated items patents and goodwill), tangible fixed assets (with the subordinated items land, buildings and machinery), other fixed assets (with the subordinated items shares and interest-bearing securities) and current assets. For each of the different types of fixed assets, our dataset includes detailed information on the amount acquired in each year.

(4) Structure of equity and liabilities: Information on the structure of equity and liabilities is required as a starting point to determine future interest and dividend flows. In particular, our dataset incorporates equity (with the subordinated items capital and other shareholders' funds) and liabilities. 
(5) Profit situation: Forecast of future profits requires information on the profit situation in the preceding year. In particular, our dataset includes EBITDA (earnings before interest, taxes, depreciation and amortization).

(6) Company-specific interest rates: To forecast financial revenue and financial expenses, company-specific credit and debt interest rates are determined. Our dataset includes the ratio of interest revenue to interest-bearing securities and the ratio of interest expenses to average liabilities.

(7) Loss carry-forwards: To be able to apply tax regulations for inter-period loss-offset, our dataset includes the amount of tax loss carry-forwards for each company at the beginning of the simulation period.

(8) Items required for the simulation of possible tax reforms: In addition, our dataset includes information that is required for the simulation of possible tax reforms. To simulate the tax consequences of a CCCTB, for example, we add sales, cost of employees and number of employees to our dataset.

The information that is required for the comparable enterprises that are used to forecast the future development of the simulation companies differs from that listed above with regard to both the items themselves and the reference period. For these companies, information for the eight years prior to the simulation period is required. Our dataset consists of the following items of information:

(1) Assets: Information on assets for comparable companies is restricted to the book values of total assets, fixed assets and other fixed assets.

(2) Profit situation: With regard to the profit situation, our dataset includes, similarly to the dataset for the companies that are included in our simulation, EBITDA, defined as operating profit/loss plus depreciation.

(3) Extraordinary result: In contrast to the dataset of simulation companies, our dataset of comparable companies includes information on the extraordinary result.

(4) Items required for the simulation of possible tax reforms: Similar to the dataset of simulation companies, our dataset of comparable enterprises incorporates information that is required for the simulation of possible tax reforms (e.g., sales, number of employees and cost of employees). 


\subsection{Definitions and notations}

In this section, we present the most important definitions and notations that are used throughout this paper. As in standard mathematical and econometric text books, $\Delta$ refers to the change of a variable from year t- 1 to year $t, \mu$ denotes the mean value, and $\sigma$ represents the standard deviation. With regard to regression equations, $\beta$ denotes the regression coefficient, and $\epsilon$ denotes the regression residuals. In addition, the following indexes are applied in the remainder of the paper:

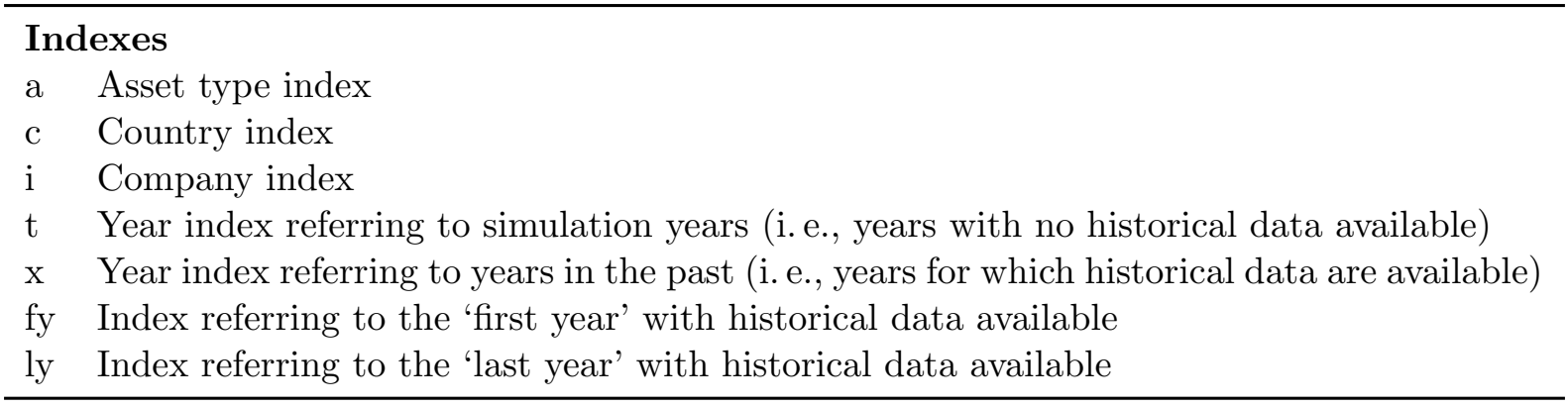

\section{Module 1: Simulation of future company development}

\subsection{Structure of the module}

The general structure of Module 1 and its interaction with the other modules is illustrated in Figure C.2. The forecasting process starts with the forecast of net investment, which is used to determine both current and total assets. In a second step, return on assets is forecasted and multiplied by total assets (without other fixed assets), as determined in the first step to derive EBITDA. The third step consists of deducting depreciation and hence calculating EBIT. To derive profit/loss before tax, EBIT is complemented by the extraordinary result, and financial expenses (revenue) are deducted (added). The resultant data form the basis of Module 3, where tax liability is assessed, and, subsequent to this calculation, of Module 5, which determines the tax revenue and tax burden. In addition, after estimating profit/loss before tax, the data are further processed in Module 4 to derive the required input data for next year's simulation. To this end, distributed dividends, equity and liabilities are determined, before the simulation of next year's development starts. The applied forecasting procedures for the corresponding items of Module 1 are described in detail below, following the structure of Figure C.2. 
Figure C.2: Simplified structure of Module 1

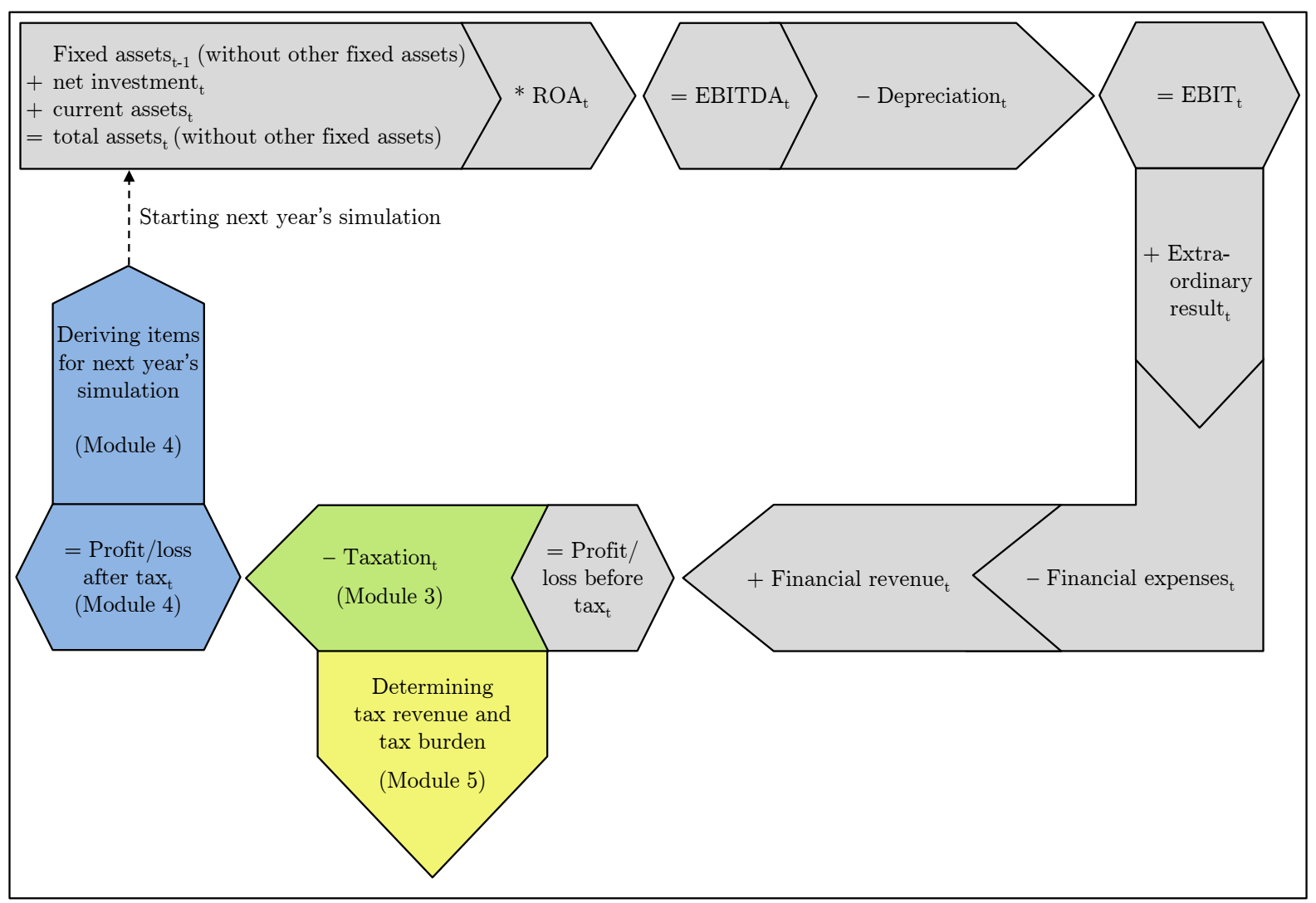

Source: Own diagram.

\subsection{Forecasting procedures}

\subsubsection{Forecasting approaches suggested by the literature}

Two parametric approaches and one non-parametric approach to forecasting earnings are currently a matter of debate in tax literature. Shevlin, 1990, Graham, 1996a and Graham, 1996b, use a random-walk approach to forecast earnings, assuming that a corporation's taxable income follows a random walk with drift. The random-walk approach incorporates a company-specific mean and standard deviation of changes in taxable income that are both held constant over time. Because companies' assets are (on average) expected to grow over time, this companyspecific stationarity may underestimate the standard deviation of changes in taxable income (see also Blouin et al., 2010), which is expected to correlate positively with the companies' assets. In addition, previous research documents that earnings, or profitability, are mean reverting (see, for example, Fama \& French, 2000), which is not accounted for in the random-walk approach.

A second approach to forecasting earnings is introduced by Graham \& Kim, 2009. They presume that part of a corporation's change in return can be explained by the previous year's 
return, leading the authors to estimate return on assets by using a first-order autoregression model. The autoregressive approach allows for mean reversion and incorporates company-specific information (at least with regard to corporations where a minimum of four historic firm-year observations is available). Nevertheless, with this approach, the problem of stationarity with regard to a single company also arises.

In contrast, Blouin et al., 2010, apply a non-parametric approach (hereinafter referred to as the bin approach). They assume that the best forecast for a corporation's future development is the past development of comparable corporations. The bin approach implicitly allows for mean reversion and is stationary only with regard to the composition of bins and not with regard to the development of single companies. However, as the bins are held constant over time, the underlying economic development is the same over the whole forecasting period. Furthermore, Graham \& Kim, 2009, point out that the bin approach ignores company-specific information that is relevant to income forecasting by treating all companies in a given bin identically.

Thus far, the literature has not demonstrated conclusively which approach is most suitable for forecasting taxable income. We therefore apply both a slightly modified bin approach and an autoregressive model. In order to forecast return on assets as described in Section C.3.2.4, we apply a combination of the bin approach and an autoregressive model. Since the bin approach enables us to forecast not only return on assets but also other balance sheet or income statement items that are required for determining tax liability, we use this approach to forecast investment in fixed asset and the extraordinary result (for a detailed description of the approach, see Section C.3.2.2). Investment in current assets, depreciation, financial expenses and financial revenue are determined based on company-specific information on the asset structure and other (forecasted) company data.

\subsubsection{Investment in tangible and intangible fixed assets}

3.2.2.1 Formation of performance-size bins To forecast investment, we apply a slightly modified version of the bin approach. ${ }^{1}$ In a first step, we generate country-specific, performance-size bins that are held constant over the simulation period. The choice of cluster variables is based on the findings of Blouin et al., 2010, as well as our own calculations demonstrating that investment and return on assets depend in particular on prior-year performance and company size. In contrast, a company's industry and other company characteristics have only a minor influence on performance (see also Fairfield et al., 2009, with regard to the impact of industry on company

\footnotetext{
${ }^{1}$ The same approach is also applied to forecast sales, number of employees and cost of employees.
} 
profitability).

In building these bins, we consider all three-year datasets that are available for corporations throughout the last eight years of our historical data. ${ }^{2}$ To qualify as a three-year dataset, the following information must be available for three consecutive years: (1) the balance sheet items total assets, fixed assets and other fixed assets; (2) the income statement items operating profit/loss and depreciation; (3) extraordinary profit/loss; and (4) the additional items sales, number of employees and cost of employees. In the following analysis, we refer to the first of these three periods as $\mathrm{x}-2$, the middle period as $\mathrm{x}-1$ and the most recent period as $\mathrm{x}$. Corporations with more than one available three-year dataset for the period under scrutiny may enter the data collection with more than one observation.

Based on the available information, we determine total assets and return on assets for years $\mathrm{x}$ and $\mathrm{x}-1$ for each of the three-year datasets that are considered. To this end, return on assets (roa) is defined as follows:

$$
\operatorname{roa}_{x}=\max \left[-2 ; \frac{o p l_{x}+\text { depreciation }_{x}}{\left(t a_{x}-o f a_{x}\right) \cdot 0.5+\left(\text { ta }_{x-1}-o f a_{x-1}\right) \cdot 0.5}\right]
$$

where $o p l$ is operating profit/loss, $t a$ is total assets and $o f a$ refers to other fixed assets. Restricting return on assets to a minimum of negative two is based on the notion that more negative values may result from accounting errors.

The universe of all three-year datasets is clustered according to the size (level one) and performance (level two) of the companies, determined as total assets and return on assets, respectively, in year x-1 (formation of equal-sized performance-size bins). This procedure is carried out per country and in such a way as to ensure that each bin contains approximately twenty three-year datasets (i. e., the number of bins per country is derived from the total number of available three-year datasets). The following example and Figure C.3 show each of the calculations, with Luxembourg serving as an example:

- 768 three-year datasets are available for Luxembourg

- approximately $38\left(=\frac{768}{20}\right)$ performance-size bins are needed

- $\sqrt{38}=6.16$ bins per level

\footnotetext{
${ }^{2}$ Note that the approach that is applied here differs from the one proposed by Blouin et al., 2010, in that observations from different years are considered. In our opinion, using observations from different periods to define the bins has the advantage of allowing different economic environments to be considered.
} 
- there are six groups on level one with $128\left(=\frac{768}{6}\right)$ three-year datasets each and 36 groups at level two with approximately $21\left(=\frac{128}{6}\right)$ three-year datasets each

Figure C.3: Formation of performance-size bins

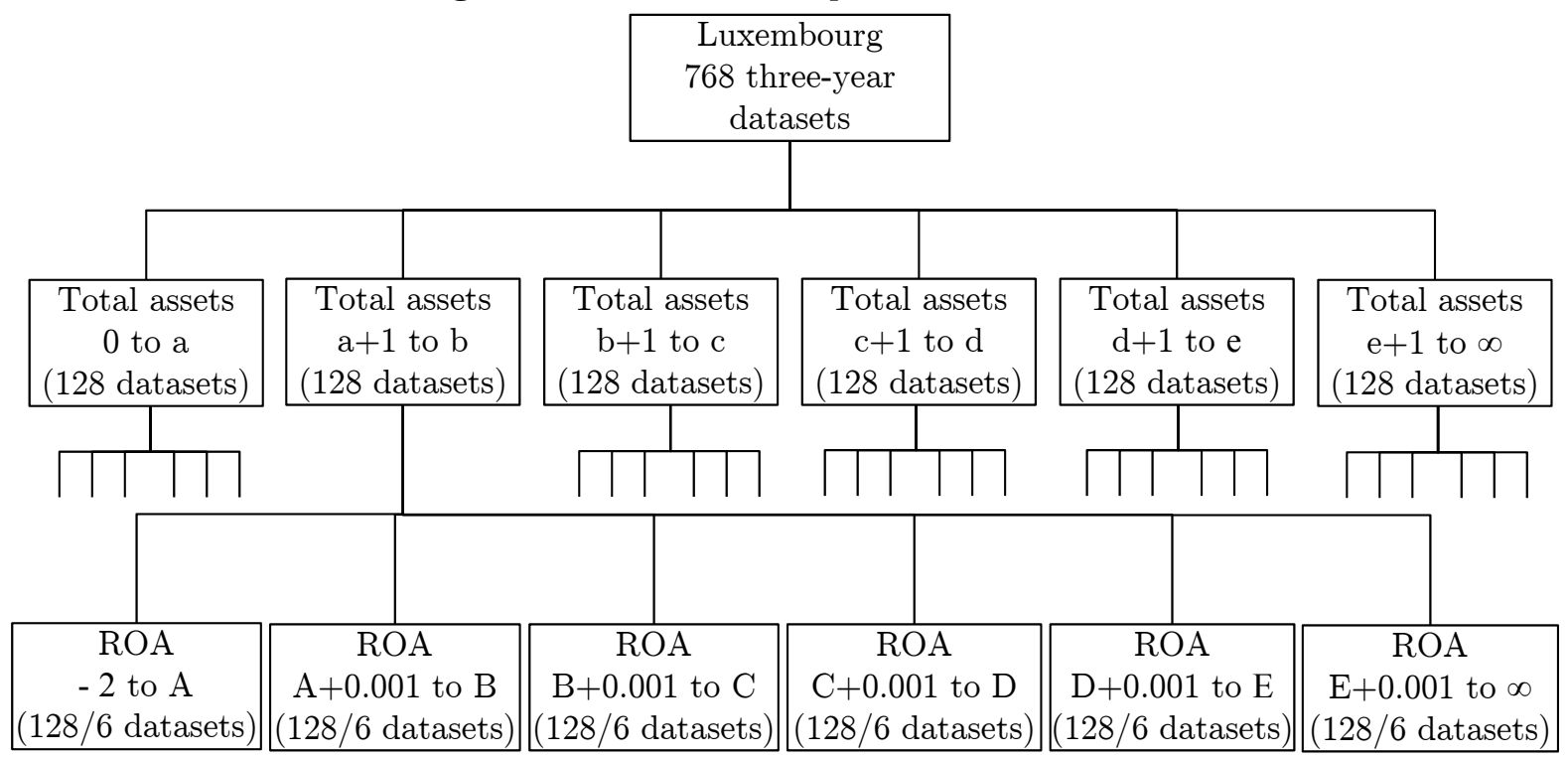

Source: Own diagram.

For each member state, we require a minimum of nine bins (three groups at the first level and nine groups at the second level). Therefore, all countries with less than $180(=9 \cdot 20)$ three-year datasets are excluded from our simulation.

To forecast future company development, we determine the change of net investment from year $\mathrm{x}-1$ to year $\mathrm{x}\left(\Delta i n v_{x}\right)$ for each bin company according to the following equation:

$$
\begin{aligned}
\Delta i n v_{x} & =i n v_{x}-i n v_{x-1} \\
\text { with } i n v_{x} & =\left(f a_{x}-o f a_{x}\right)-\left(f a_{x-1}-o f a_{x-1}\right)
\end{aligned}
$$

where $f a$ and $o f a$ refer to the book value of fixed and other fixed assets, respectively. $\Delta i n v$ is condensed by determining the median values across all companies per bin. The median values form the basis for forecasting future company development of the companies in the sample, as described in the following section.

3.2.2.2 Forecasting based on the bins' development in the past The basic assumption underlying our forecasting procedure is that the best forecast of a company's next year development is the average development of comparable companies in the past. To simulate a company's development in year t, we therefore assign each company to the relevant performance-size bin, 
as determined in the previous section (based on total assets and return on assets for year t1). We forecast company development over a period of four years. In this respect, in the following sections, the first simulated year is denoted as first sim year and the last simulated year is denoted as last sim year, meaning that the allocation procedure is repeated for each $t \in[$ first sim year; last sim year $]$. In doing so, we follow Blouin et al., 2010, by holding the bins constant over time. In contrast to their study, however, we include observations from different periods in the bins and therefore do not rely on the economic development of one specific year for our forecast.

Based on this allocation, we use the median values reflecting each bin's development from year $\mathrm{x}-1$ to year $\mathrm{x}$ (determined as described in the previous section) to forecast the net investment of sample company i in year $\mathrm{t}\left(\widehat{i n v}_{i, t}\right)$. The following equation formally describes this procedure:

$$
\widehat{i n v}_{i, t}=i n v_{i, t-1}+\operatorname{median}\left(\Delta i n v^{b i n}\right)
$$

\subsubsection{Derivation of gross investment and apportionment to different asset types In or-} der to determine the amount and structure of new investments, i. e., the distribution among the different types of assets (patents and goodwill in the case of intangibles; land, buildings and machinery in the case of tangibles), we derive gross investment by totaling overall net investment, as determined in the previous section, and overall current-year economic depreciation. To apportion gross investment to different asset types, we distinguish between three different cases:

(a) If gross investment in tangible and intangible fixed assets is positive and exceeds the amount of current-year economic depreciation of the existing assets, investments are allocated in a first step to each type of asset in the corresponding amount of economic depreciation. The remaining net investment is attributed proportionally to the acquisition costs of existing assets of each type.

(b) If gross investment is positive but smaller than the amount of current-year economic depreciation of the existing assets, gross investment is attributed to the different types of assets in proportion to their amount of current-year economic depreciation.

(c) If gross investment is negative, all asset-type/asset-age classes are reduced in proportion to their acquisition costs.

Investments are assumed to be carried out at the end of the corresponding fiscal year. 


\subsubsection{Investment in other fixed assets and current assets and determination of total assets}

Total assets are defined as the total of tangible and intangible fixed assets, other fixed assets and current assets. Application of the bin approach yields a forecast of current-year net investment in tangible and intangible fixed assets $\left(\widehat{i n v}_{i, t}\right)$, which is allocated to the different asset types, as described in the previous section. The book value of current-year tangible $(t f a)$ and intangible fixed assets (ifa) is determined as follows:

$$
t f a_{i, t}+i f a_{i, t}=t f a_{i, t-1}+i f a_{i, t-1}+\widehat{i n v}_{i, t}
$$

The bin approach's prediction of (net) investments in tangible and intangible fixed assets also forms the basis for determining other fixed assets. In this respect, we assume that investments in other fixed assets are carried out in proportion to investments in tangible and intangible fixed assets. However, we assume that shares held in other companies are constant over time, meaning that changes in the book value of other fixed assets refer exclusively to interest-bearing securities.

Current assets of year $\mathrm{t}$ are defined as current assets in year $\mathrm{t}-1$ multiplied by a companyspecific growth rate. The growth rate is the minimum of the growth factor as defined below $\left(G F_{i}\right)$ and the growth of fixed assets in the current year. In particular, current assets of company $\mathrm{i}$ in year $\mathrm{t}$ are defined as follows ( $f a$ refers to fixed assets without financial fixed assets):

$$
\begin{gathered}
\text { current assets }_{i, t}=\text { current assets }_{i, t-1} \cdot \min \left(G F_{i} ; \frac{f a_{i, t}-f a_{i, t-1}}{f a_{i, t-1}}+1\right) \\
\text { with } 1 \leq G F_{i} \leq 5
\end{gathered}
$$

The constant, company-specific growth factor is based on the compound annual growth rate (the geometric mean) in the past and is applied in different modules of the model, where it is limited to certain maximum values depending on the area of application. The growth factor of company $\mathrm{i}$ is determined according to the following equation (as above, $f a$ refers to fixed assets without financial fixed assets):

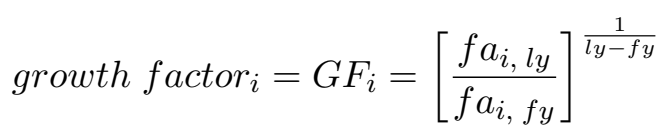




\subsubsection{Return on assets and determination of EBITDA}

To forecast return on assets, we apply a combination of the bin approach and an autoregressive model. In a first step, return on assets is forecasted using the bin approach, similar to the procedure described above. For each of the companies in the bins, the change in return on assets ( $\Delta$ roa) from year $\mathrm{x}-1$ to year $\mathrm{x}$ is determined according to the following equation:

$$
\Delta r o a_{x}=\frac{\operatorname{roa}_{x}-\operatorname{roa}_{x-1}}{\operatorname{roa}_{x-1}}
$$

The resultant variables are condensed by determining the median values and standard deviations across all companies per bin. ${ }^{3}$ After allocating each simulation company to a specific bin based on its total assets and return on assets in year t-1, return on assets is forecasted under uncertainty by applying a Monte Carlo simulation (50 iterations) based on the median and standard deviation determined for the corresponding bin. ${ }^{4}$ The forecasting procedure follows Equations C.10 and C.11 below.

$$
\begin{gathered}
\widehat{\operatorname{roa}}_{i, t}=\operatorname{roa}_{i, t-1} \cdot\left(1+\widehat{\Delta r o a}^{b i n}\right) \\
\text { with } \widehat{\Delta r o a}^{b i n} \stackrel{i i d}{\sim} \mathcal{N}\left(\text { median }\left(r o a^{b i n}\right) ; \sigma^{2}\left(r o a^{b i n}\right)\right)
\end{gathered}
$$

In a second step, return on assets is forecasted using an autoregressive approach. To this end, we estimate the following regression equation:

$$
\begin{aligned}
& \operatorname{roa}_{i, t}=\mu_{i}+\rho_{i} \cdot \operatorname{roa}_{i, t-1}+\beta_{i} \cdot G D P_{t}+\epsilon_{i, t} \\
& \text { with } \epsilon \stackrel{i i d}{\sim} \mathcal{N}\left(0 ; \sigma_{i}^{2}\right)
\end{aligned}
$$

In this respect, $\mu_{i}$ is the drift, $\rho_{i}$ is the autoregressive parameter, $\beta_{i}$ is the regression coefficient of GDP and $\epsilon_{i, t}$ are the residuals. To determine the regression coefficients, all available historic observations are taken into account. Equation C.12 is estimated for each company and for panels of firm-year observations (cluster), which are formed by using six income classes (two for lossmaking companies and four for profitable companies) and 13 industry classes, meaning that we estimate $\mu, \rho, \beta$ and $\epsilon$ for a total of 78 different bins. In order to preserve the micro-analytic character of our simulation to the greatest extent possible, the coefficients resulting from the

\footnotetext{
${ }^{3}$ For bins that include observations with previous year's roa close to zero, we refer to the absolute instead of the relative change to avoid influential outliers.

${ }^{4}$ To determine the standard deviation, we drop influential outliers.
} 
cluster-specific regressions are (only) applied if either the number of observations per company is smaller than four or at least one of the following conditions is met for the company-specific regression: $\left|\rho_{i}\right|>0.8, \sigma_{i}^{2}>0.8$ or $\mu_{i} /\left(1-\rho_{i}\right)>0.6$. In applying these criteria, we generally follow Graham \& Kim, 2009. Employing the estimated regression coefficients, we define return on assets as follows:

$$
\begin{aligned}
& \widehat{r o a}_{i, t}=\mu_{i}+\rho_{i} \cdot \operatorname{roa}_{i, t-1}+\beta_{i} \cdot G D P_{t}+r n \cdot \sigma\left(\epsilon_{i, t}\right) \\
& \text { with } r n \stackrel{i i d}{\sim} \mathcal{N}(0 ; 1)
\end{aligned}
$$

As with the bin approach, a Monte Carlo simulation with 50 iterations is applied; $r n$ is a standard normally-distributed random number between zero and one.

In a last step, the two forecasts of return on assets (one resulting from the bin approach and one resulting from the $\mathrm{AR}(1)$ approach) are combined. In cases in which the coefficient $\beta$ of Equation C.12 is statistically significant, at least at the 20 percent level, we use the mean value of the two estimates and employ an additional country-specific modification to account for the general economic development. If GDP exerts no significant influence, we rely exclusively on the value that is forecasted by the bin approach.

EBITDA is derived by multiplying return on assets by the forecasted value of total assets without financial fixed assets.

\subsubsection{Depreciation}

Depreciation is calculated based on the company-specific structure of depreciable assets, which are clustered with respect to the asset type (we differentiate between land, buildings, machinery, goodwill and patents) and the acquisition year. In determining depreciation expense, we assume book depreciation to equal tax depreciation. To this end, depreciation rates are derived and applied for each of the asset-type/asset-age clusters, thereby taking into account country-specific tax depreciation regulations regarding the depreciation method (straight-line method versus declining-balance method) and the asset's useful life. For each asset type, the depreciation rate is determined by assuming acquisition costs of 100 and calculating the corresponding depreciation expense for every year of the asset's useful life. For each year of the asset's useful life, the depreciation rate is defined as the ratio of depreciation expense to the acquisition costs. Hence, for a declining balance depreciation of 30 percent, the depreciation rate amounts to $0.3(=30 / 100)$ 
in the first year, $0.21(=21 / 100)$ in second year and so forth.

Company-specific depreciation expense is then determined as the total of all products of an asset cluster and depreciation rate, where an asset cluster includes the acquisition costs of all assets of type $a$ that were acquired in year x of the assets' useful life. Equation C.16 illustrates the determination of tax depreciation, where $\mathrm{X}$ refers to the useful life of the different asset types.

$$
\text { depreciation }_{i, t}=\sum_{a=1}^{5} \sum_{x=1}^{X}{\text { acquisition } \text { cost }_{i, a}, x} \cdot \text { depreciation rate }_{a, x}
$$

\subsubsection{Extraordinary result}

The extraordinary result is forecasted under uncertainty, applying a Monte Carlo simulation with 50 iterations. To this end, we define the bins as described above and allocate the simulation companies to these bins. To determine whether the extraordinary result of a simulation company differs from zero, we draw a uniformly distributed random number between zero and one for each company. This random number is compared to the percentage of companies in the corresponding bin that report an extraordinary profit or loss that is different from zero. In cases in which the random number is larger than this percentage, an extraordinary result of zero is assumed. In cases in which the random number is smaller, the amount of the extraordinary result $(e p l)$ is determined according to the following equations:

$$
\begin{aligned}
e p l_{i, t} & =\left(\mu\left(e p l^{b i n}\right)+r n \cdot \sigma\left(e p l^{b i n}\right)\right) \cdot\left(t a_{t}-o f a_{t}+t a_{t-1}-o f a_{t-1}\right) / 2 \\
\text { with } e p l^{b i n} & =\frac{e p l_{t}}{\left(t a_{t}-o f a_{t}+t a_{t-1}-o f a_{t-1}\right) / 2} \quad \text { and } \quad r n \stackrel{i i d}{\sim} \mathcal{N}(0,1)
\end{aligned}
$$

As above, $r n$ is a standard normally-distributed random number, and $t a$ ( $o f a$ ) denotes total assets (other fixed assets).

\subsubsection{Financial expenses}

Regarding financial expenses, we distinguish between interest expenses and other tax-deductible financial expenses, which may comprise, for example, amortization on financial assets. Our forecast of interest expenses relies on the notion that interest is charged on long- and shortterm debt (liabilities), reported, on average, at the beginning and end of the financial year. 
Liabilities are derived as a residual item of the simulation process by deducting equity from total assets. However, forecasting equity refers to the after-tax profit and thus necessitates an assessment of financial expenses (see Section C.6). Because of this circular reference, we are not able to use current-year liabilities to predict financial expenses. We account for this by adjusting the previous year's liabilities by a company-specific growth factor $(G F$, as defined in Equation C.8), which is limited here to a value of 1.5.

The applicable debt interest rate is determined for each company based on items reported on the company's balance sheets and income statements in the past. It is defined as the ratio of interest paid to average liabilities in the two years prior to the simulation. To control for the general development of debt interest rates in the company's residence country, the companyspecific interest rate is adjusted in two different ways, and we apply the maximum of the two resultant interest rates. The two interest rates are denoted by $i r 1$ and $i r 2$ and are defined according to Equations C.19 and C.20. Both interest rates are limited to 200 percent to mitigate a distortion of the results attributable to influential outliers; cir refers to the country-specific debt interest rate for corporations. ${ }^{5}$

$$
\begin{aligned}
& \operatorname{ir} 1=\min \left[2 ; \frac{\text { interest paid }_{l y}}{\left(\text { liabilities }_{l y}+\text { liabilities }_{l y-1}\right) / 2}-\left(\operatorname{cir}_{l y}-\text { cir }_{t}\right)\right] \\
& i r 2=\min \left[2 ; \frac{\text { interest paid }_{l y}}{\left(\text { liabilities }_{l y}+\text { liabilities }_{l y-1}\right) / 2} \cdot \frac{\text { cir }_{t}}{\text { cir }_{l y}}\right]
\end{aligned}
$$

The determination of interest expenses is expressed in Equation C.21:

$$
\text { interest expenses }_{t}=\left[\text { liabilities }_{t-1} \cdot\left(1+G F_{i}\right)\right] / 2 \cdot \max (\text { ir } 1 ; \text { ir } 2)
$$

To estimate other financial expenses, we determine the proportion of years in which overall financial expenses exceed interest paid, based on financial statements reported by the companies in the past. This share is compared to a company-specific, uniformly distributed, random number between zero and one. If this random number is smaller than the derived proportion, we calculate other financial expenses for the company as follows: First, we calculate the average companyspecific ratio of the difference between financial expenses and interest paid to liabilities. This ratio is calculated from historical data and refers only to years in which financial expenses $>$ interest paid. Second, this ratio is multiplied by the previous year's liabilities. Equation C.22

\footnotetext{
${ }^{5}$ Country-specific debt interest rates are primarily taken from EuRostAT. When interest rates were not available from Eurostat, the web pages of national central banks served as a data source.
} 
formally expresses the determination of other financial expenses $(o f e)$ :

$$
o f e=\sum_{t=f y+1}^{l y} \frac{\text { financial expenses }_{t}-\text { interest paid }_{t}}{\left(\text { liabilities }_{t}+\text { liabilities }_{t-1}\right) / 2} /(l y-(f y+1)) \cdot \text { liabilities }_{t-1}
$$

\subsubsection{Financial revenue}

With regard to financial revenue, we differentiate (based on the structure of other fixed assets) between interest and dividend income. ${ }^{6}$ To forecast interest income, we distinguish between companies with other fixed assets that are larger than zero and companies without other fixed assets in the current year.

For companies without other fixed assets, we determine the ratio of financial revenue to average total assets based on the last available financial statement and multiply this ratio by average total assets $(t a)$. The resultant determination of financial revenue is expressed in Equation C.23. Given that other fixed assets are equal to zero for some firms, these firms do not hold shares in other companies and therefore do not receive dividends. Financial revenue for these companies then consists only of interest income:

$$
\text { interest revenue }_{t}=\text { financial revenue }_{t}=\frac{\text { financial revenue }_{l y}}{\left(t a_{l y}+t a_{l y-1}\right) / 2} \cdot\left(t a_{t}+t a_{t-1}\right) / 2
$$

For companies with other fixed assets that are larger than zero, interest income is determined as the difference between other fixed assets and shareholdings (i. e., equity investments), multiplied by a company-specific interest rate. The interest rate is derived from the last available financial statement and is determined as interest income divided by debt investments (i. e., the difference between other fixed assets and shareholdings). The determination of interest income for these companies is expressed by the following equation (as above, of a refers to other fixed assets):

$$
\text { interest revenue }_{t}=\left(\text { of }_{t-1}-\text { shareholdings }_{t-1}\right) \cdot \frac{\text { financial revenue }_{l y}-\text { dividends }_{l y}}{o f a_{l y}-\text { shareholdings }_{l y}}
$$

Dividends received are determined by multiplying the dividends that the subsidiary distributed

\footnotetext{
${ }^{6}$ Profits received from partnerships are disregarded because ASSERT is limited to the taxation of corporate income. Because partnerships account for only 4.62 percent of all subsidiaries that are included in our data, this assumption should not affect our results to any significant extent. In the case of cross-shareholdings, circular calculations may arise. We therefore assume that distributions of the company holding the smaller share are zero. If both companies hold the same share, zero distributions are assumed for both companies.
} 
by the corresponding parent company's shares. To this end, distributed dividends are calculated as described in the next section.

However, because ASSERT does not provide a full coverage of subsidiaries, the dividends that are estimated by this direct approach are likely to underestimate the dividends that are actually received. We account for this by adding a so-called "baseline dividend" in specific cases. As will be described in Section C.10.3.2, dividend distributions for the pre-simulation period are determined by applying an indirect approach, which avoids this underestimation of received dividends. We therefore determine received dividends for the last year with available historical data (ly) using

both the indirect approach $\left(d i v_{i, l y}^{\text {ind }}\right.$; see Section C.10.3.2) and the direct approach $\left(d i v_{i, l y}^{d i r}\right.$; see above). If positive, the difference between indirectly and directly calculated dividends is the "baseline dividend" for company i. The "baseline-dividend" increases the received dividends of company $\mathrm{i}$ in every simulation year and is adjusted for the general economic development according to the following equation ( $g d p$ is the gross domestic product growth):

$$
\text { base dividend }_{i, t}=\max \left[0 ; d i v_{i, l y}^{i n d}-d i v_{i, l y}^{d i r}\right] \cdot\left(1+\frac{g d p_{t-1}+g d p_{t}}{2}-\frac{g d p_{l y-1}+g d p_{l y}}{2}\right)
$$

\section{Module 2: Possible behavioral responses}

The second module accounts for possible behavioral responses. This module has yet to be finalized and aims to determine company responses to changes in tax regulations. In particular, companies may adjust their capital structure and their investment behavior in response to tax reforms. However, since the micro-simulation model is based on data for existing corporations, it will not be possible to account for decisions with regard to legal form, which may also be influenced by taxation. 


\section{Module 3: Deriving tax liability}

\subsection{Tax liability under law in force}

\subsubsection{General approach}

The tax liability of company $\mathrm{i}$ in year $\mathrm{t}$ is determined according to the following general equation:

$$
\begin{aligned}
& \stackrel{i n c 3_{i, t}}{\stackrel{i n c 2_{i, t}}{i n c 1_{i, t}}} \\
& \operatorname{Tax}_{i, t}=\tau_{c(i), t} \cdot\left(\text { plbt }_{i, t}-\text { tax-free dividends }_{i, t}+g t_{i, t}+\text { loss-offset }_{i, t}\right)
\end{aligned}
$$

where $\tau_{c, t}$ is the statutory tax rate in country c and year $\mathrm{t}, p l b t_{i, t}$ is profit/loss before taxation, as derived in Module $1, g t_{i, t}$ represents increases or decreases in income resulting from an applicable group taxation regime and loss-offset $t_{i, t}$ denotes the consequences of inter-period lossoffset, if available. We refer to plbt as a starting point, because this item already accounts for tax depreciation, as described in Section C.3.2.5. As shown by the brackets above Equation C.26, inc1 refers to profit/loss before tax less tax-free dividends, inc2 is taxable income before lossoffset, and inc3 refers to taxable income after loss-offset. The determination of tax-free dividends and the implementation of group taxation regulations and inter-period loss-offset provisions are described in detail in the following sections.

\subsubsection{Determination of tax-free dividends}

Financial revenue (and therefore also profit/loss before tax) comprises both interest revenue and received dividends. Thus, it is necessary to deduct tax-free dividends from profit/loss before tax to derive taxable income. As distributed dividends can only be determined after tax liability is derived, we base our determination of received (and tax-free) dividends on the previous year's distributions to avoid circular references. We therefore assume that dividends that are distributed at the end of the year are received at the beginning of the next year.

In determining tax-free dividends, we refer to the regulations that are currently prevailing in the different EU member states. However, in the case of "baseline dividends" (see Section C.3.2.8), we are not able to identify the dividend's country of origin, making it impossible to determine the amount of a potential tax credit. We therefore assume, for the purpose of our simulation, that the consequences of a tax credit are equal to a 100-percent tax exemption if tax law provides for a full tax credit for (domestic or foreign) taxes on distributed profits. This 
simplifying assumption affects tax liability only in cases in which the tax rate in the dividend's country of origin is smaller than the tax rate in the country of destination. Otherwise, the use of exemption method and the use of credit method result in the same tax payments. Potentially resulting inaccuracies should therefore not affect our results to any significant extent.

\subsubsection{Group taxation}

5.1.3.1 Application requirements Currently, 18 out of the EU 28 member states provide for special regulations regarding the taxation of corporate groups. In determining whether a group taxation regime applies, we assume that companies opt to apply the regime whenever the relevant legal requirements are met. These requirements include a minimum holding condition, the threshold of which ranges between 50 percent and 95 percent. Further cross-country differences arise depending on whether indirect shareholdings are considered and how they are determined (on an additive or multiplicative basis). These regulations are considered in our model.

The German tax group regulation ("Organschaft") differs from the regimes that are codified in other European member states insofar as a profit-and-loss transfer agreement is a prerequisite for the formation of a tax group (a similar requirement was also applied in Austria until 2005). The existence of a profit-and-loss transfer agreement can be observed in our data, as the related transfers of profits and losses are reported in the subsidiary's profit and loss statement as extraordinary income. Thus, we assume that an "Organschaft" exists if both the relevant minimum participation requirement is met and the profit/loss of a subsidiary is transferred completely to its parent company (i.e., the subsidiary reports a profit/loss for period of zero, whereas the profit/loss after tax is different from zero).

5.1.3.2 Tax consequences Codified group taxation regimes also differ with regard to the tax consequences. All available systems provide for an intra-group loss-offset, whereas some member states additionally allow for a full or partial elimination of profits from intra-group transactions. As our data do not include any information on these transactions, we cannot take the latter consequences into account, meaning that the consideration of group taxation regimes in ASSERT is limited to the offset of losses. In this respect, the available regimes can be classified into the following three types: pooling onto parent, group contribution and group relief.

In the case of pooling onto parent, the income of the subsidiaries is attributed to and taxed at the level of the parent company, as expressed by Equations C.27 and C.28. gt $t_{t}$ stands for the amount that must be added/deducted from the parent's or subsidiary's taxable income as a 
consequence of applying the group taxation regime. The term $i n c 1_{i, t}$ refers to the preliminary taxable income (profit/loss before taxation less the tax-free dividends of company i in year $\mathrm{t}$, as also noted in Equation C.26), whereas $\sum_{i=1}^{n} i n c 1_{i, t}$ refers to the preliminary definition of taxable income of all companies i belonging to a common tax group $\mathrm{k}$ (including the parent company). $i n c 1_{p, t}$ is the preliminary taxable income of the parent company. For Germany, it is additionally taken into account that the transfer of income for tax purposes is accompanied by a transfer of cash in the same amount.

$$
\begin{aligned}
\text { Parent company: } g t_{t} & =\sum_{i=1}^{n} i n c 1_{i, t}-i n c 1_{p, t} \\
\text { Subsidiary: } g t_{t} & =i n c 1_{i, t} \cdot(-1)
\end{aligned}
$$

In case of the group-relief and group-contribution systems, all results of a tax group are aggregated and proportionally divided between the group members. If an overall loss is incurred, it will be shared only by the loss-making companies. Similarly, overall profits are only shared by the profitable companies. The tax consequences of the group-relief system are determined based on the following set of equations. The term $i n c 1_{i, t}$ refers to the preliminary taxable income of company $\mathrm{i}$ in year $\mathrm{t}$, whereas $i n c 1_{k+, t}\left(i n c 1_{k-, t}\right)$ refers to the overall positive (negative) preliminary taxable income of all $\mathrm{n}$ companies i belonging as a subsidiary or parent to a common tax group $\mathrm{k}$. The term $g t_{i, t}$ denotes the amount that must be added/deducted from company i's preliminary taxable income in order to account for the effects of the group-relief or groupcontribution system. For countries that apply the group-contribution system, it is additionally taken into account that the transfer of income for tax purposes is accompanied by a transfer of cash in the same amount.

$$
\begin{aligned}
& i n c 1_{k+, t}=\sum_{i=1}^{n} \max \left(i n c 1_{i} ; 0\right) \\
& i n c 1_{k-, t}=\sum_{i=1}^{n} \min \left(i n c 1_{i} ; 0\right)
\end{aligned}
$$

$$
\begin{aligned}
& \text { if } i n c 1_{k+, t} \geq-i n c 1_{k-, t}: \quad g t_{i, t}=\max \left(\frac{i n c 1_{i, t}}{i n c 1_{k+, t}} ; 0\right) \cdot\left(i n c 1_{k+, t}+i n c 1_{k-, t}\right)-i n c 1_{i, t} \\
& \text { if } i n c 1_{k+, t}<-i n c 1_{k-, t}: \quad g t_{i, t}=\max \left(\frac{i n c 1_{i, t}}{i n c 1_{k-, t}} ; 0\right) \cdot\left(i n c 1_{k+, t}+i n c 1_{k-, t}\right)-i n c 1_{i, t}
\end{aligned}
$$




\subsubsection{Inter-period loss-offset}

In determining the consequences of inter-period loss-offset, we take into account the general availability of loss carry-forward and carry-back as well as restrictions with regard to time or amount, if applicable in the member state. Equations C.33 to C.35 express the incorporation of loss-offset regulations into our calculation of taxable income in an exemplary manner. We differentiate between years with negative (i. e., a loss carry-back may apply) and positive taxable income before loss-offset (i. e., existing loss carry-forwards may be used). inc $2_{i, t}$ denotes taxable income before loss-offset (i. e., profit/loss for before taxation less tax-free dividends, considering the group taxation system), inc $3_{i, t}$ refers to taxable income after loss-offset (see also Equation C.26), limit is the amount that the loss carry-forward/carry-back is restricted to and $l c f_{i, t}$ denotes the amount of existing tax loss carry-forwards of company i in year t. For the loss-offset regulations that are most commonly applied in the EU member states, loss-offset is defined as follows:

(a) $i n c 2 \leq 0$, no loss carry-back:

$$
\text { loss-offset }_{i, t}=i n c 2_{i, t} \cdot(-1)
$$

(b) inc2 $\leq 0$, loss carry-back with a restriction regarding both time and amount

$$
\text { loss-offset }_{i, t}=i n c 2_{i, t} \cdot(-1)-\max \left(0 ; \min \left(-i n c 2_{i, t} ; \text { inc } 3_{i, t-1} ; \text { limit }\right)\right)
$$

(c) inc2 $>0$, loss carry-forward with a restriction regarding both time and amount

$$
\text { loss-offset }_{i, t}=\min \left(i n c 2_{i, t} ; \text { lcf } f_{i, t} ; \text { limit }\right) \cdot(-1)
$$

To determine the tax loss carry-forwards existing in year $\mathrm{t}\left(l c f_{i, t}\right)$, possible time restrictions are taken into account. That is, in countries in which tax loss carry-forward is limited to a certain number of years, loss carry-forwards are forecasted in separate "baskets", depending on their year of occurrence. When determining taxable income, loss carry-forwards for early years are used first and loss carry-forwards are eliminated if they are older than the number of years that the carry-forward is restricted to. 


\subsection{Determining the consequences of tax reforms}

The main objective of applying tax-related micro-simulation models is to assess the consequences of possible tax reforms. Therefore, ASSERT is designed to allow for the incorporation of amendments to all the tax provisions that are considered, including amendments to provisions regarding tax depreciation, dividend tax treatment, intra-group and inter-period loss-offset, cross-border taxable income allocation (direct versus indirect methods) and applicable tax rates. Furthermore, the modular design of ASSERT also allows for an extension of the model by incorporating additional (and possibly new) tax regulations.

In determining the consequences of tax reforms, we leave the forecast of next year's earnings and investments unaffected, at least as long as we do not consider behavioral responses. Rather, we solely amend the procedures that translate these forecasted earnings into tax liabilities. Changes in the tax liability resulting from a tax reform are associated with liquidity effects. We account for these effects by adjusting distributed dividends and the resultant capital structure.

\section{Module 4: Deriving items for next year's simulation}

To determine the amount and structure of next year's equity and liabilities, we start by determining possible injections of equity capital. In this regard, each of the following three steps is carried out separately, depending on whether the total of the previous year's shareholders' funds and current-year profit/loss for period is smaller than zero.

In a first step, we determine the likelihood of an equity capital injection based on historical balance sheet data. In this respect, we assume a capital increase when the total of the previous year's shareholders' funds and current-year profit/loss for period is smaller than current-year shareholders' funds. The probability of a capital injection is then determined as the frequency of years with a capital increase over the total number of years with historical data per firm.

In a second step, we draw a uniformly distributed random number between zero and one. This random number is compared to the likelihood for a capital increase. If the random number is smaller than or equal to the determined probability of a capital injection, the amount of the capital increase is determined in a third step, expressed by Equations C.36 and C.37:

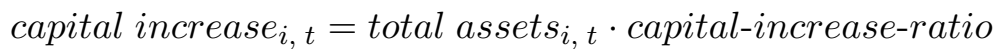

with $\quad$ capital-increase-ratio $=\frac{s h f_{t}-\left(s h f_{t-1}+p l_{t}\right)}{\text { total asset } s_{t}}$ 
The capital-increase-ratio is determined as the country-specific average for all years and companies included in the set of historical data. $s h f$ refers to shareholders' funds, and $p l$ refers to profit/loss for period. The ratio can take values between zero and one and is determined only for firm-year observations that are characterized by a capital increase.

As a second source of changes in equity, we determine dividend distributions for each of the simulation companies. Dividend distributions are estimated for all companies of a corporate group by employing a bottom-up approach. That is, we start with the lowest-tier subsidiary that is distributing dividends to the direct parent company, which distributes dividends to the nexttier company and so forth. We use two different approaches to determine distributed dividends and choose the maximum of the two resultant values.

According to the first approach, we compare the sum of previous-year shareholders' funds and current-year profit/loss after tax to current-year total assets. If the sum of the first two items is larger, the dividend distribution is assumed to be equal to shareholders' funds plus profit/loss after tax minus total assets.

According to the second approach, dividends are determined by applying a company-specific payout ratio, calculated on the basis of the most recent historical financial statement data. In this respect, profit/loss after tax is denoted as plat, and the following payout ratio is calculated separately for years with plat $>0$ (index pos) and for years with plat $\leq 0$ (index neg); osf stands for other shareholders' funds.

$$
\text { payout-ratio }_{i}=\sum_{t=l y-2}^{l y} \frac{\text { plat }_{t}-\left(o s f_{t}-o s f_{t-1}\right)}{\text { plat }_{t}+o s f_{t-1}} / \text { number of years }
$$

To determine the dividend distributions, we differentiate between three different situations, as shown in the following equations:

(a) plat $>0$

$$
\text { distributed dividends }=\text { payout-ratio }{ }_{i}^{\text {pos }} \cdot\left(\text { plat }_{t}+o s f_{t}\right)
$$

(b) plat $\leq 0$ and shareholders funds + plat - capital $>0$

$$
\text { distributed dividends }=\text { payout-ratio }{ }_{i}^{\text {neg }} \cdot\left(\text { plat }_{t}+\text { osf }_{t}\right)
$$


(c) plat $\leq 0$ and shareholders funds + plat - capital $\leq 0$

distributed dividends $=0$

Subsequent to the determination of dividend distributions, we estimate the equity of company $\mathrm{i}$ in year $\mathrm{t}$ as the previous year's equity plus the current year's after tax profit (or loss) minus any dividend distributions. Liabilities then are the residual between total assets and equity.

\section{Module 5: Determining tax revenue and tax burden}

\subsection{Determination of revenue impacts}

In determining the revenue consequences of tax reforms, three issues have to be considered. First, appropriate indicators for tax revenue have to be determined. Second, the results from all simulation runs have to be condensed, and third, the condensed simulation results have to be extrapolated in an adequate manner.

Tax revenue is determined in ASSERT using three different definitions. First, we define gross tax revenue as the total of all tax liabilities. That is, tax loss carry-forwards prevailing at the end of the simulation period are disregarded and are only reported as a separate item. Second, net tax revenue is determined, defined as gross tax revenue minus the tax value of unused loss carry-forwards at the end of the simulation period. Our third measure considers timing effects when defining tax revenue and is defined as the net present value of net tax revenue. The measure is determined by discounting tax revenue at a uniform rate, assuming that loss carry-forwards at the end of the simulation period are utilized in subsequent periods at a constant rate that differs across the member states. The member-state-specific average ratio of utilized losses to loss carry-forwards is calculated based on the outcome of our simulation. The present value of tax loss carry-forwards that are remaining at the end of the simulation period is then determined as the present value of the reduction of tax liabilities caused by these loss carry-forwards.

By applying these different definitions of tax revenue, we aim to more clearly show the possible effects of provisions that affect the distribution of the tax base over time (e.g., loss carryforwards). More restrictive loss-offset provisions may have a permanent effect on tax revenue, if losses carried forward from earlier periods are ultimately lost. As a consequence, a higher aggregate net tax revenue is observed, whereas gross revenue increases only to the extent that these unused losses could be utilized if less restrictive provisions were applied. The net present 
value of tax revenue also reflects mere timing effects.

Since tax liability is estimated under uncertainty, the resultant tax liabilities for each corporation and year have to be condensed into one single number. Hence, for each corporate group and each stand-alone company, we choose one simulation run as the basis for extrapolation. ${ }^{7}$ The following steps are carried out to determine the appropriate simulation run:

(1) Adding up tax liabilities for each corporate group, year and simulation run.

(2) Determining the median value of the aggregated tax liabilities for each corporate group and each year.

(3) Calculating the absolute differences between aggregated tax liabilities and its median for each observation and adding up these differences for each corporate group and simulation run over all years.

(4) Choosing the simulation run with the smallest total of absolute differences.

Forecasting tax revenue in ASSERT bears the problem that although the applied database covers a large proportion of the universe of all existing corporations (see also Table C.5 for the general data coverage of AMADEUS), it lacks complete balance sheet information for a significant share of these companies. Relative changes in tax revenue determined on this basis are not distorted, as long as the simulation companies constitute a representative sample of all existing corporations. However, since the requirements for being included in the simulation process are more frequently fulfilled by large companies, this is presumably not the case. To overcome possible distortions that may result from an underrepresentation of small and medium-sized corporations, we account for this imbalance by applying the following extrapolation procedure. First, all corporations that are included in the simulation process are allocated to different clusters according to their country of residence, organizational structure (i. e., whether the corporation belongs to a corporate group) and size (in terms of total assets); each cluster is defined to consist of 200 corporations. Second, all companies that are included in AMADEus are allocated to these clusters, and we determine expansion factors by dividing the sum of the total assets of all companies in a cluster by the sum of the total assets of all simulation companies in their cluster. These factors are adjusted to account for an underrepresentation of unprofitable companies in Amadeus, using national tax statistics. The resultant expansion factors are used

\footnotetext{
${ }^{7}$ Another possibility would be to use the mean value of all estimated tax liabilities. However, several robustness tests showed that this procedure may be heavily influenced by outliers, which is why we decided against using this approach.
} 
to extrapolate both tax liability and existing tax loss carry-forwards at the end of the simulation period.

\subsection{Determination of tax burden}

In determining the tax burden, we distinguish between marginal and average tax rates, both of which are determined at the individual company level and at group level. To determine marginal tax rates, we rely on the method proposed by Graham, 1996a, Graham, 1996b and Shevlin, 1990, which was also applied in the studies by Blouin et al., 2010 and Graham \& Kim, 2009. In these studies, "the marginal tax rate is defined as the present value of current and expected future taxes paid on an additional dollar of income earned today" (Graham, 1996a, page 44).

In contrast, no common standard has emerged in the existing literature with respect to the definition of average tax rates. From an economic point of view, the average tax burden should be defined as the ratio of discounted future tax liability to discounted future economic earnings. The latter cannot be derived from financial statements and must therefore be approximated (Collins \& Shackelford, 1995). Common definitions set tax liability (or tax payments) in relation to a profit figure, assets employed, operating revenue or the operating cash flow. Any specification with a numerator that depends on underlying (tax) accounting principles determines a statutory tax burden rather than an average tax burden (Plesko, 2003). Furthermore, international comparisons might be biased because of international differences in the accounting provisions (Nicodème, 2001, Collins \& Shackelford, 1995). If tax liability refers to operating revenue or assets employed, a bias is created with respect to international differences in profitability. Using operating cash flow to determine the average tax rate enhances the comparability across countries, but induces a bias of the average tax rates with respect to the capital intensity. Companies with high capital intensity should, other things being equal, have a lower average tax rate (Schratzenstaller, 2004, Nicodème, 2001, Zimmerman, 1983).

For the purposes of our analysis, we measure the average (company/group) tax rate as the reduction of the present value of cash flow to equity. The cash flow is derived indirectly from the financial statements and is defined as the total of operating cash flow, cash flow from debt financing and cash flow from investments $\left(l t l_{i, t}\right.$ are long-term liabilities, which are composed of 
debt and provisions, and $p l b t_{i, t}$ refers to profit/loss before taxation of company i in year $\mathrm{t}$ ):

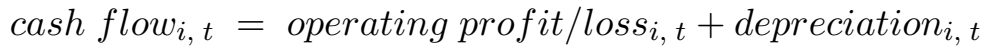

$$
\begin{aligned}
& +\Delta l t l_{i, t}+\text { interest revenue }_{i, t}-\text { interest expenses }_{i, t} \\
& -\left(\Delta \text { fixed }_{\text {assets }_{i, t}}+\text { depreciation }_{i, t}\right) \\
& \Leftrightarrow \operatorname{cash}^{\text {flow }_{i, t}}=\operatorname{plbt}_{i, t}+\Delta l t l_{i, t}-\Delta \text { fixed asset }_{i, t}
\end{aligned}
$$

In order to determine the average tax rate $(a t r)$, cash flows and tax liabilities $\left(\operatorname{tax}_{i, t}\right)$ are discounted at a uniform rate $r$. The average tax rate is defined in Equation C.44. Loss carryforwards that remain at the end of the simulation period $\left(l c f_{i, t}\right)$ are assumed to be utilized in subsequent periods at a constant rate that differs across the member states (utilization rate ${ }_{c(i)}$ ), with the present value of the related tax advantage denoted by LCF $\left(\tau_{c(i)}\right.$ is the country-specific tax rate, and $n$ refers to the number of years within which loss carry-forwards are, on average, utilized; $n$ is determined from historical data).

$$
\begin{aligned}
& \operatorname{atr}_{i, t}=\frac{\sum_{t=1}^{10} \operatorname{tax}_{i, t} \cdot(1+r)^{-t}-L C F_{i, t}}{\sum_{t=1}^{10} \operatorname{cash}_{\text {flow }} \cdot t \cdot(1+r)^{-t}}
\end{aligned}
$$

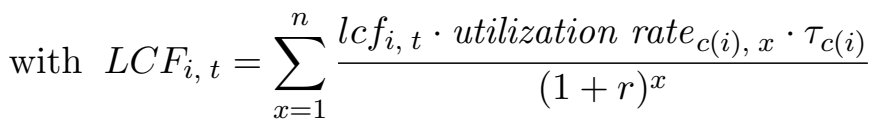

The applied cash-flow definition should avoid a biased mismatch between the numerator and the denominator of the average tax burden as long as the total of tax depreciation equals the capital expenditure during the period under consideration. ${ }^{8}$ The same applies to borrowings and settlement of debts.

In addition to determining the average tax rate of the individual company/group, we determine country averages that reflect the attractiveness of each country as an investment location. To this end, we exclude from our analysis companies/groups with a total cash flow that deviates by more than 100 percent from the total of profits and losses before tax over the period under consideration (owing to the possible inaccuracies addressed above). In order to avoid errors due to outliers in the sample, we also exclude companies/groups with an average tax rate that differs by more than 100 percent from the median average tax rate of the member state. The average

\footnotetext{
${ }^{8}$ As companies were, on average, growing during the simulation period, net investments should, on average, slightly exceed total depreciation during the simulation period. This results in a slight overestimation of the average tax rate.
} 
tax rate for the member states is then assessed as the mean of the average tax rates for the remaining companies/groups in the sample.

In order to determine country averages, we introduce one further distinction. We distinguish the average tax rate of companies/groups with a positive total cash flow over the simulation period $\left(a t r^{+}\right)$from the average tax rate of companies/groups with negative total cash flows $\left(a t r^{-}\right)$. This distinction is necessary, because the average tax rates for companies/groups with positive cash flows must be interpreted differently from the average tax rates for companies/groups with negative cash flows. In the first case, the average tax rate has to be interpreted as a tax burden (i. e., the lower the tax rate is, the more attractive the country is as an investment location from a pure tax perspective). In the second case, the average tax rate has to be interpreted as a tax relief (i.e., the higher the tax rate is, the more attractive the country is as an investment location). Both measures $\left(a t r^{+}\right.$and $\left.a t r^{-}\right)$are accommodated to create a combined average tax rate, which takes into account both the tax burden on profits $\left(a t r^{+}\right)$and the additional tax burden resulting from the tax discrimination for losses $\left(a t r^{-}\right)$, weighted by the number of companies/groups in the sample with negative total cash flows over the simulation period $\left(\frac{n^{-}}{n^{+}+n^{-}}\right)$. The following equation for the combined average tax rate results:

$$
a t r_{i, t}=a t r_{i, t}^{+}+\frac{n^{-}}{n^{+}+n^{-}} \cdot\left(a t r_{i, t}^{+}-a t r_{i, t}^{-}\right)
$$

\section{Accuracy of the model}

To evaluate the forecasting quality of ASSERT, we calculate the mean and median values as well as standard deviations of the forecasted items and compare them to the values actually realized, as reported in an updated version of the AmADEus database (AMADEus update 196). Moreover, we determine correlations between simulated and realized items. In particular, we evaluate the forecasting quality of the items total assets, liabilities, depreciation and operating profit/loss (EBIT). Results relating to all countries covered in ASSERT are shown in Table C.1. The results of country-specific evaluations can be found in Appendix 3 in Tables C.8 to C.17. These tables are provided for those ten countries with the most firm-year observations available in both ASSERT and AMADEUs update 196. Forecasted and realized data refer to the years 2008 to 2010. It is not possible to evaluate simulation results of 2011 , since the respective data are not included in the latest available Amadeus update. Besides, the number of observations in Table C.1 is smaller than the number of corporations included in the simulation process, 
because Table C.1 is restricted to companies, which are included in both the simulation process and Amadeus update 196.

Table C.1: Forecasting quality of ASSERT

\begin{tabular}{|c|c|c|c|c|}
\hline Year & & 2008 & 2009 & 2010 \\
\hline Total assets & Number of observations & 410,501 & 389,552 & 97,470 \\
\hline \multirow[t]{3}{*}{ ASSERT } & Mean & 12,097 & 12,757 & 17,689 \\
\hline & Median & 1,675 & 1,755 & 1,481 \\
\hline & Standard deviation & 193,958 & 201,568 & 282,866 \\
\hline \multirow[t]{3}{*}{ Amadeus } & Mean & 13,249 & 13,486 & 21,086 \\
\hline & Median & 1,816 & 1,832 & 1,682 \\
\hline & Standard deviation & 251,250 & 261,674 & 410,911 \\
\hline Comparison & Correlation & 0.909 & 0.889 & 0.918 \\
\hline Liabilities & Number of observations & 410,503 & 389,550 & 97,470 \\
\hline \multirow[t]{3}{*}{ ASSERT } & Mean & 7,922 & 8,629 & 11,8033 \\
\hline & Median & 1,061 & 1,136 & 950 \\
\hline & Standard deviation & 131,171 & 143,657 & 201,688 \\
\hline \multirow[t]{3}{*}{ Amadeus } & Mean & 8,200 & 8,122 & 12,083 \\
\hline & Median & 1,082 & 1,053 & 927 \\
\hline & Standard deviation & 139,716 & 140,776 & 228,371 \\
\hline Comparison & Correlation & 0.870 & 0.832 & 0.875 \\
\hline Depreciation & Number of observations & 407,190 & 384,899 & 96,395 \\
\hline \multirow[t]{3}{*}{ ASSERT } & Mean & 392 & 425 & 529 \\
\hline & Median & 45 & 52 & 48 \\
\hline & Standard deviation & 8,049 & 8,712 & 9,851 \\
\hline \multirow[t]{3}{*}{ Amadeus } & Mean & 368 & 381 & 465 \\
\hline & Median & 43 & 45 & 43 \\
\hline & Standard deviation & 6,443 & 6,427 & 7,158 \\
\hline Comparison & Correlation & 0.903 & 0.879 & 0.878 \\
\hline Operating profit/loss & Number of observations & 410,387 & 389,471 & 97,453 \\
\hline \multirow[t]{3}{*}{ ASSERT } & Mean & 676 & 589 & 955 \\
\hline & Median & 95 & 82 & 100 \\
\hline & Standard deviation & 12,532 & 17,777 & 16,793 \\
\hline \multirow[t]{3}{*}{ Amadeus } & Mean & 646 & 534 & 933 \\
\hline & Median & 95 & 73 & 103 \\
\hline & Standard deviation & 18,598 & 14,910 & 17,049 \\
\hline Comparison & Correlation & 0.603 & 0.215 & 0.469 \\
\hline
\end{tabular}


As can be seen from Table C.1, the forecasting quality of ASSERT is very satisfying. The statistical measures are sufficiently similar to each other, especially when it is taken into account that the results are not corrected for outliers. ${ }^{9}$ The correlation between realized and simulated values is around ninety percent for total assets and depreciation. Similarly, the correlation with regard to liabilities is between eighty and ninety percent for the three years considered. The correlation with regard to the operating profit/loss is around 43 percent, on average. The smaller correlation observed for this item comes as no surprise, since forecasting profitability covers more than just growth effects. In addition, it can be observed that the correlation of operating profit/loss is smallest in 2009. This is reasonable, as results in 2009 were heavily influenced by the global financial and economic crisis, which made accurate forecasting more difficult. When looking at the development of the forecasting quality over time, it becomes apparent that it decreases only slightly, if at all. We therefore assume sufficient forecasting quality for the whole simulation period of four years and do not expect a significant decline in the forecasting quality in 2011 as compared to the years 2008 to 2010.

We also analyze, to what extent differences in the mean value of realized and forecasted items are statistically significant. We apply a country and year specific t-test and compare the mean values of the items forecasted in ASSERT to the mean values of the realized items in AMADEUS update 196. The corresponding p-values are reported in Tables C.8 to C.17 in Appendix 3. In more than 60 percent of all cases, we do not find a difference in the mean value that is statistically significant at the one- or five-percent level.

Since ASSERT aims at determining revenue consequences of tax reforms, estimating the resultant tax revenue with sufficient precision is the main objective of the simulation, while a correct estimation of the underlying components is only secondary, given that tax revenue is determined correctly. We therefore compare tax revenue estimated in ASSERT with realized tax revenue in Germany between 2008 and 2011 (see Oestreicher et al., 2012). The comparison revealed that forecasted and realized tax revenue are very similar to each other and that they developed analogously over time (with the exception of the year 2011). As the primary objective of ASSERT is the determination of relative revenue consequences of tax reforms rather than forecasting tax revenue over time, estimating the correct amount of tax revenue is not as important as avoiding systematic over- or underestimations of tax revenue. Based on the preceding analyses, it does not appear as if ASSERT is subject to such miscalculations.

\footnotetext{
${ }^{9}$ Two firm-year observations were disregarded for this analysis, which probably include erroneous information in Amadeus update 196.
} 


\section{Summary}

The micro-simulation model described in this paper, ASSERT, is designed to quantify the tax consequences of a corporate tax reform in the EU member states on the tax revenue and tax burden of the companies concerned. In doing so, ASSERT differs from existing similar microsimulation models in that it includes $19 \mathrm{EU}$ member states instead of being limited to one specific country and that it uses forecasting procedures to simulate future company performance and tax liability. Accordingly, ASSERT allows us to assess the tax consequences of tax reforms regarding the taxation of multinational groups (e.g., the introduction of a CCCTB), to incorporate behavioral responses and to estimate revenue with respect to the cross-country second-round effects of national tax reforms in one member state. 


\section{Appendix 1 - Generation of database}

\subsection{Database and data selection}

ASSERT draws primarily on company micro-data that are included in the AmADEUs database. AmADEUs is a comprehensive pan-European database that contains financial information on about nine million public and private companies in 38 European countries and is made available by the private database provider Bureau van Dijk. ${ }^{10}$ The database contains standardized (consolidated and unconsolidated) annual accounts, financial ratios, and information on the legal forms, industry and ownership of the companies that are included in the database. It is the policy of Bureau van Dijk to include all companies for which plausible and up-to-date information is available. Consequently, AmAdEus provides neither a complete sample nor a randomly chosen sample of companies, and this must be taken into account whenever simulation results are discussed. In Amadeus, balance sheets and profit and loss accounts are presented in an aggregated, standardized layout that is outlined in Table C.2 and Table C.3.

Table C.2: Balance sheet items available in Amadeus

\begin{tabular}{l|l}
\hline Assets & Equity and Liabilities \\
\hline Fixed assets & Shareholders' funds \\
- Intangible fixed assets & - Capital \\
- Tangible fixed assets & - Other shareholders' funds \\
- Other fixed assets & Non-current liabilities \\
Current assets & - Long-term debt \\
- Stocks & - Other non-current liabilities \\
- Debtors & Current liabilities \\
- Other current assets & - Loans \\
- Thereof cash and cash equivalents & - Creditors \\
& - Other current liabilities \\
\hline Total assets & Total shareholders' funds and liabilities \\
\hline
\end{tabular}

According to the data description that is provided by Bureau van Dijk, the item other fixed assets primarily consists of financial fixed assets. On the right-hand side of the balance sheet, the item capital reports subscribed capital, whereas other shareholders' funds comprises capital reserves, profit reserves and retained earnings.

With regard to the profit and loss account, sales is restricted to earnings from the core business activity, whereas operating revenue/turnover also includes other operating earnings. In addition

\footnotetext{
${ }^{10}$ For a discussion of the advantages and disadvantages of AMADEus in comparison to other sources of company micro-data, see Poppe, 2007.
} 
Table C.3: Income statement items available in Amadeus

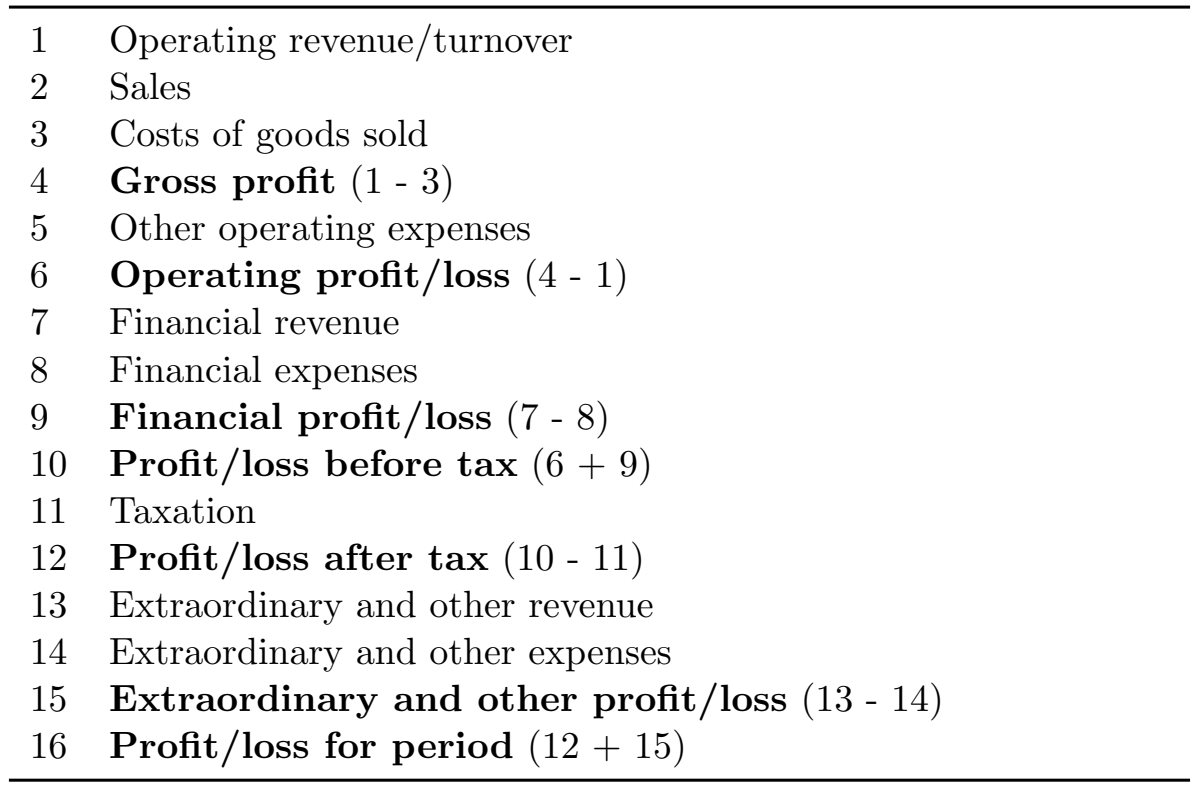

to the items covered in Tables C.2 and C.3, export turnover, material costs, cost of employees, number of employees, depreciation and interest paid are reported.

Furthermore, Amadeus includes information on the companies' legal form, industry and shareholders. However, this information is reported only for one specific point in time in each update, which is, in most cases, the date of the last available financial statement. We use legal forms and industry codes (primary NACE codes) from the last available update as well as ownership information taken from four different updates of AMADEus (the mapping of corporate group structures and the identification of corporate groups' industries are described in Sections C.10.2.2 and C.10.3.4).

The taxation of a company depends on its legal form. Therefore, each company in our sample must be classified as either a corporation or a partnership for tax purposes. To this end, we rely on the legal form as provided in Amadeus and the list of legal forms falling under the ParentSubsidiary Directive to classify companies as corporations. ${ }^{11}$ Whereas corporations constitute a separate subject to tax in all member states, the income of partnerships is taxed in the hands of the individual partners in most member states ("pass-through taxation" or "transparency principle"). As the information provided in AMADEus does not allow for a reliable estimation of individual income tax, ASSERT is restricted to the taxation of corporations.

In selecting relevant sample companies, in a first step, we include all unconsolidated annual accounts, given that a company has its legal seat in one of the EU 28 member states and operates

\footnotetext{
${ }^{11}$ See the annex of the Parent-Subsidiary Directive for this list.
} 
in the legal form of a corporation. In order to qualify as a simulation company, further data requirements have to be met, which are briefly summarized and substantiated below (see also Section C.2.2 in this respect):

(1) Industry sector classification

(2) Shareholding information and corporate group structure

(3) Tangible fixed assets, intangible fixed assets, other fixed assets and total assets for the last two reported years; asset structure (i.e., the subordinated items of tangible fixed assets, intangible fixed assets and other fixed assets as well as the corresponding years of acquisition)

(4) Equity (with the subordinated items capital and other shareholders' funds) and liabilities for the last two reported years

(5) Operating profit/loss and depreciation for the last two reported years

(6) Company-specific credit and debt interest rates, i. e., financial revenue and financial expenses for the last reported year

(7) Tax loss carry-forwards for the last reported year

(8) Sales, number of employees and cost of employees for the last two reported years

(9) At least 180 three-year datasets per country to be able to apply the bin approach (see Section C.3.2.2); a comprehensive number of observations per country to allow for a realistic estimation of revenue consequences.

The resultant data sample in its current version is illustrated in detail in Section C.11.

\subsection{Preparation of the original data}

\subsubsection{Financial data}

10.2.1.1 Elimination of erroneous data The accuracy of a micro-simulation model depends essentially on the quality of the underlying data. We therefore apply comprehensive data preparation procedures in order to eliminate erroneous and implausible information and (where possible) supplement missing values. To this end, we (a) assess the balance sheet for differences between total assets and total equity and liabilities, (b) eliminate (subject to certain exceptions) negative items in the balance sheet and income statement, (c) insert missing values and 
(d) eliminate erroneous information in the balance sheet and income statement in the case of differences between totals/subtotals and the sums of subordinated items.

In applying step (a), no financial statement appeared to show discrepancies between total assets and total equity and liabilities. With regard to step (b), we observed 931 financial statements with negative balance-sheet totals as well as a number of financial statements with negative subordinated items in either the balance sheet or the income statement. Because the data are processed and aggregated automatically by the database provider, negative items would normally be attributable to accounting errors and therefore would lead us to delete the balance sheet or income statement. However, we accept negative values for the balance sheet items other fixed assets (negative book values are related to investments in partnerships), stocks (negative values are possible if stocks are netted against advance payments), cash/other current assets (negative values are possible if bank account balances are negative) and other shareholders' funds (negative values are possible if loss carry-forwards exceed reserves). With regard to capital, negative values are accepted for partnerships, as equity is not always reported in separate items for these companies. In contrast, in the case of corporations, negative values for capital are assumed to be the consequence of accounting errors. As far as the income statement is concerned, negative values should only exist with regard to totals and subtotals. We therefore delete income statements completely if negative values are observed for one of the income statement items operating revenue/turnover, sales, costs of goods sold or other operating expenses. If negative values occur only in items (other than (sub)totals) that are reported in the income statements below operating profit/loss, we delete the income statement except for the items sales and operating revenue. In step (c), we insert missing values. The calculation of missing values is limited to cases in which the supplementation can be carried out unambiguously on the basis of totals, subtotals and/or subordinated items. The supplementation of missing values in other cases would require reference to industry and/or country averages, which would curtail the individuality of the micro-data. Finally, in step (d), we verify both the totals and the subtotals in the balance sheets and income statements for mathematical correctness. Any differences below a value of two (values are reported in thousands of euro) are accepted as rounding differences. Larger differences lead to the deletion of the smallest possible (defective) section of the corresponding balance sheet or income statement.

10.2.1.2 Imputation of missing values Inserting missing values as described in the previous section is limited to cases in which this supplementation could be made free of ambiguity. 
As an exception to this general rule, we estimate missing values for the items sales and cost of employees if the related items operating revenue/turnover and number of employees are reported in Amadeus and vice versa. Two arguments support the calculation of values for these items. First, the values of these items can be expected to be strongly correlated with the values of the related items, indicating that estimating missing values for these items should be possible with sufficient accuracy. Second, for a number of countries, AmADEus provides values for only one of the related items, meaning that calculating values for missing items is necessary to avoid excluding all companies from these countries.

Our approach to calculating these missing items aims to consider the characteristics of the individual companies to the greatest extent possible but, at the same time, to avoid any substantial impact of influential outliers. Based on this notion, we apply the following five-step procedure to determine missing values for sales and operating revenue (cost of employees and number of employees) based on the median ratios for sales to operating revenue (cost of employees to number of employees). We use (a) ratios of the same corporation over all years if at least three values are available. Otherwise, we rely on (b) ratios of the same industry in the same country in the same year, (c) ratios of the same country in the same year over all industries, (d) ratios of the same industry in the same country over all years or (e) ratios of the same country over all industries and years. To apply one of the ratios for (b) to (d), we require a minimum of ten values.

10.2.1.3 Elimination of implausible data In addition to eliminating financial statements with information that is obviously erroneous owing to either discrepancies or negative items, we use a second algorithm that identifies and eliminates mathematically correct but implausible information. To this end, we examine both the relations of different financial statement items within one year and the development of certain items over time. To test the plausibility of information reported within a single financial statement, we apply the following set of conditions 
(cempl refers to cost of employees and depr refers to depreciation):

$$
\begin{aligned}
\text { sales } & \leq \text { operating revenue } \\
\text { export turnover } & \leq \text { operating revenue } \\
\text { material costs } & \leq \text { cost of goods sold }+\Delta \text { stocks } \\
\text { material costs }+ \text { cempl }+ \text { depr } & \leq \text { cost of goods sold }+ \text { operating expenses }+\Delta \text { stocks } \\
\text { interest expenses } & \leq \text { financial expenses } \\
\text { number of employees } & <\text { cost of employees }
\end{aligned}
$$

If condition C.47 is not met, we delete the entire income statement; if condition C.52 is not satisfied, we eliminate only the items number of employees and cost of employees. If one of the remaining conditions is violated, we delete the income statement and all other financial statement items that are included in the equation with the exception of operating revenue and sales. In addition, we examine the items total assets, sales, operating revenue, cost of employees, number of employees and the ratio of cost of employees to number of employees over time. In particular, we eliminate the whole balance sheet (income statement) if the relative change in total assets (sales, operating revenue) from year $\mathrm{x}$ to year $\mathrm{x}+1$ is larger than 10,000 percent or smaller than -99 percent. To this end, the second criterion is only applied if the item is of considerable size in year t (i. e., larger than 100,000).

10.2.1.4 Currency conversion Original financial statement information is extracted from the Amadeus database in euro. This may create inaccuracies in countries with local currencies if balance sheet or income statement items are compared over time (as, for example, in the case of investment in fixed assets). A positive value for investment in this case may reflect both real activities and mere exchange rate changes. Before starting the simulation procedure, we therefore convert data from all non-euro countries (i. e., Bulgaria, Czech Republic, Denmark, United Kingdom, Hungary, Poland, Romania, Slovakia and Sweden) into local currency. ${ }^{12}$

Company-year-specific exchange rates depend on the account date and are available in the database for most company years. In cases in which the account date but no exchange rate is available in Amadeus, we refer to the mean exchange rate over all companies in the same

\footnotetext{
${ }^{12}$ Only dividend distributions are converted again into the parent company's local currency to avoid inconsistencies between the distributing and the receiving company.
} 
country and year with the same account date. In cases in which neither the account date nor the exchange rate is available, we refer to the country and year specific average exchange rate.

\subsubsection{Ownership data and corporate group structures}

Shareholder information is reported only with reference to one specific point in time in each AmADEus update. We are therefore not able to consider ownership information and group structures on a year-by-year basis. Incorporating all available information, we use four different updates of Amadeus (update 64 for 1994 to 1999; update 100 for 2000 to 2002; update 125 for 2003 to 2005; update 172 for 2006 to 2007) and assume that ownership data and group structures are unchanged between different reporting dates.

Table C.4: Preparation of ownership data

\begin{tabular}{|c|c|c|c|c|c|c|c|}
\hline \multicolumn{4}{|c|}{ Database information } & \multicolumn{4}{|c|}{ Level of adjustment } \\
\hline & & & & I & & II & III \\
\hline 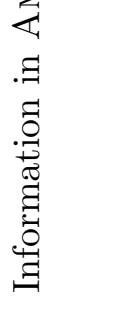 & $\begin{array}{l}\stackrel{\infty}{\Xi} \\
\stackrel{\Xi}{\Xi} \\
\stackrel{\Xi}{\Sigma}\end{array}$ & 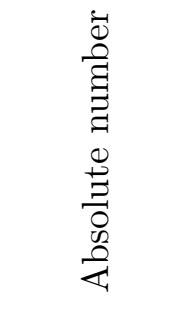 & 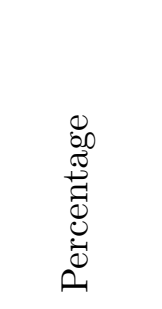 & 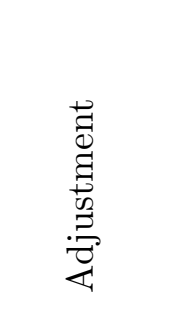 & 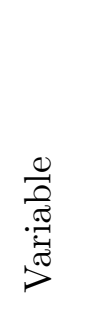 & 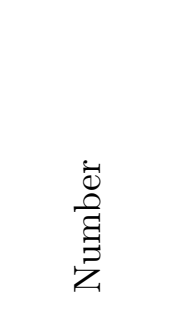 & 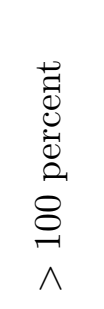 \\
\hline $\mathrm{X}$ & known & $10,808,015$ & $75.99 \%$ & no & & & $\stackrel{8}{8}$ \\
\hline- & unknown & $2,139,937$ & $15.06 \%$ & 0.00 & yes & $1,925,878$ & $\underset{8}{8}$ \\
\hline$<\mathrm{X}$ & smaller X & 2,452 & $0.02 \%$ & $\mathrm{X}-0.01$ & yes & 14 & $\wedge$ \\
\hline$>\mathrm{X}$ & greater $\mathrm{X}$ & 112,902 & $0.79 \%$ & $\mathrm{X}+0.01$ & yes & 112,733 & 80 \\
\hline CQPI & $50 \%+1$ share & 7 & $0.00 \%$ & 50.01 & & & 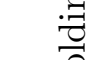 \\
\hline $\mathrm{G}$ & error in database & 86 & $0.00 \%$ & 100.00 & & & 2 \\
\hline $\mathrm{MO}$ & controlling interest & 1,465 & $0.01 \%$ & 50.01 & yes & 1,455 & $\overbrace{\overparen{\Xi}}^{\infty}$ \\
\hline$+/-\mathrm{X}$ & $+/-\mathrm{X}$ & 329 & $0.00 \%$ & $\mathrm{X}$ & & & चี \\
\hline $\mathrm{NG}$ & under $1 \%$ & 1,714 & $0.01 \%$ & 0.01 & & & $\overleftrightarrow{0}$ \\
\hline WO & above $98 \%$ & $1,155,526$ & $8.12 \%$ & 98.01 & & & W \\
\hline Sum & & $14,222,433$ & $100.00 \%$ & $3,414,418$ & & $2,040,080$ & 2.418 \\
\hline
\end{tabular}

Again, we apply a data preparation algorithm to eliminate erroneous information, particularly if the overall participation of all reported shareholders for a company exceeds 100 percent, and to impute missing information or specify reported shareholdings. ${ }^{13}$ The procedure for preparing ownership data is described in Table C.4. The numbers reported in this table refer to the

\footnotetext{
${ }^{13}$ See also Koch, 2010 and, in detail, Poppe, 2007, for a slightly adjusted description of this step.
} 
shareholders of all companies that are included in AmADEus; thus, a company held by five different shareholders is included five times in Table C.4. Participation is reported to be free of ambiguity in 75.99 percent of the cases (coded in AMADEUS as X and CQPI).${ }^{14}$ For the remaining entries, the participation rate is unknown or is reported only in terms of a minimum or maximum value. Ownership information that is not reported with a precise participation quota is amended using a three step approach: First, each of the entries is assigned an exact participation rate. It equals zero if the actual participation rate is completely unknown; otherwise, the reported minimum or maximum value is attributed (column I). Second, the participation rate of all of these entries is increased (entries with unknown or minimum participation) or decreased (entries with maximum participation) to ensure that the participation rates that are reported for all companies add up to 100 percent (column II). To this end, the following equation is applied:

$$
p_{a}=p_{b}+\left(100 \%-\sum p_{b}\right) / n_{s}
$$

where $p_{a}$ is the participation rate after amendment, $p_{b}$ is the participation rate before amendment and $\sum p_{b}$ is the known overall participation rate of all shareholders before amendment, all reported as a percentage; $n_{s}$ is the number of shareholders whose participation is amended. Finally, we eliminate all companies with an overall participation rate $\left(p_{a}\right)$ that exceeds 100 percent (column III).

Group companies differ from stand-alone companies with respect to both the applicable tax provisions (e.g., applicability of group taxation regimes) and the options for shifting profits to low-tax countries. To consider these differences in our simulation, we assign a distinct group ID to each group company that is equal to the Bureau van Dijk ID number of the parent company. Amadeus includes information on both direct and top-level shareholders ("ultimate owner"). For both types of shareholders, the shareholder's name, identification number, country and participation rate as well as the type of shareholder is reported. The following categories are used for type of shareholder:

(a) Banks and financial companies

(b) Insurance companies

(c) Industrial companies

(d) Mutual and pension funds/nominees/trusts/trustees

(e) Foundations/research institutes

(f) Public authorities/states/governments

\footnotetext{
${ }^{14}$ All values refer to AMADEUs update 172.
} 
(g) One or more named individuals or families

(h) Employees/managers/directors

(i) Public unnamed private shareholders

(j) Other unnamed shareholders

With regard to the reported percentage of participation, direct shareholdings are distinguished from total shareholdings in AmADEus. A direct shareholding includes only shares that are directly held in a specific corporation, whereas the total shareholding reflects both directly and indirectly held shares. The latter is only included in AmADEus if it can be extracted directly from an available information source (i. e., Bureau van Dijk does not calculate total shareholdings based on the available information regarding direct shareholdings). Accordingly, the calculation method for total shareholdings (additive or multiplicative) depends on the information source; it may therefore involve inconsistencies and is disregarded for our purposes.

To identify parent companies, we do not rely directly on the "ultimate owner", as reported in Amadeus. Bureau van Dijk used a minimum participation threshold of 24.9 percent to define the ultimate owner in earlier updates of AmADEus; this threshold deviates from the 50-percent threshold that is usually applied to define corporate groups for accounting and tax purposes. We therefore refer to the information on direct shareholdings. Based on this information, we combine all corporations that are controlled by a common European or non-European parent corporation to form one corporate group. Financial control is assumed if the controlling company directly or indirectly holds a share of at least 50 percent in the controlled company. To this end, all direct and indirect shareholdings are summed up, given that, for the indirect shareholdings, the controlling company holds (directly or indirectly) a share of at least 50 percent in the intermediary company. Indirect shareholdings are considered irrespective of whether the intermediary company operates in the legal form of a corporation or partnership. ${ }^{15}$

\subsection{Modification of the original data}

\subsubsection{Structure of non-financial fixed assets}

10.3.1.1 General approach Determining future tax depreciation necessitates detailed information on the structure of assets, with respect to both the asset type and the acquisition date. This information, however, is not provided first hand in AMADEus, since the subdivision of fixed assets is limited to the items intangible fixed assets, tangible fixed assets and other fixed assets (composing, in particular, financial fixed assets). In addition, information on the acquisition

\footnotetext{
${ }^{15}$ This step is described in detail in Poppe, 2007.
} 
dates of these assets is lacking. This makes it necessary to combine the AMADEus data with more detailed information from other sources and/or to apply algorithms to impute missing information, based on the available data.

Indications for the imputation of missing asset structure information may be taken from three different sources. First, external sources of information can provide additional guidance with regard to the type of assets. Such information would (at best) include EU-wide, disaggregated, company-specific accounting data that can be matched with AMADEus based on an unambiguous identifier. Possible data sources include the database OsIRIs, a number of country databases provided by Bureau van Dijk and the BACH database, published by the European Commission's Directorate for General Economic and Financial Affairs. However, none of these databases entirely meets the requirements outlined above. Most only partly cover the EU member states (i.e., BACH and country databases of Bureau van Dijk), refer to consolidated rather than unconsolidated accounts (OSIRIS) and/or include aggregated information instead of company-specific micro-data (BACH). Altogether, it appears that OsiRIs best serves our purposes, as it includes micro-data for companies in all EU member states.

Second, company age and average company growth may serve as possible indicators for the age structure of assets. Assuming that (a) companies purchase a complete first set of new assets in the year of foundation, (b) companies replace these assets in subsequent years in accord with the amount of economic depreciation and (c) capital-widening investments are constant over time and over different types of assets, the age structure of currently available assets can be modeled based on a simple aging algorithm.

Third, the ratio of depreciation expense to the book value of fixed assets may serve as an indicator for the asset structure, even though depreciation expense is reported only in terms of an overall value in AmAdeus. Nonetheless, high values for this ratio arise if fixed assets consist, ceteris paribus, to a larger extent of assets with a short overall expected useful life and with a short remaining useful life. If a distinct depreciation method can be assigned to each type of asset in each of the considered countries (for a similar approach, see Devereux \& Griffith, 1999), then the ratio of depreciation expense to book value of fixed assets describes the entirety of all possible asset-age/asset-type combinations.

The specific approach that is applied in our simulation model is selected because it meets the following three requirements: First, the resultant asset structure should be among the possible ones, i.e., the depreciation expense that is determined based on the resultant asset structure should match the depreciation expense that is reported in AmADEus. Second, the applied ap- 
proach should ensure a maximum of company individualism with a minimum of arbitrariness. Third, the applied approach should minimize errors with respect to both the asset type and the asset age. To meet these requirements, we determine (in a first step) starting values for the ratio of each asset-type/asset-age combination. These starting values are (in a second step) modified on a step-by-step basis in order to ensure conformity with the actual depreciation expense that is reported in Amadeus. During the simulation period, the resultant asset structure is applied to determine tax depreciation and to allocate investments to different asset types.

10.3.1.2 Starting values for the book values of different types of assets Starting values for the proportion of each asset type are taken from the OsIRIs database. OsIRIS is a worldwide database that is provided by Bureau van Dijk that includes consolidated financial statements for large listed and not listed companies. In contrast to those in AMADEUs, financial statements in OsIRIS are not reported in an aggregated format. This allows us to determine country- and/or industry-specific averages for the proportion of different types of assets. To limit the arbitrariness of the resultant asset structure, we restrict the disaggregation of tangible fixed assets to the items land, buildings and machinery, whereas intangible fixed assets are disaggregated into goodwill and patents. In particular, we determine the following ratios:

(1) Land to land and buildings $\left(p_{\text {land }}\right)$ : As this ratio differs across countries rather than across industries, we determine it as a simple country average. For countries with less than ten observations in OsIRIS, we refer to the average across all countries.

(2) Machinery to land, buildings and machinery ( $\left.p_{\text {machinery }}\right)$ : We determine this ratio as an average within country-industry clusters. As this ratio differs across industries rather than across countries, we refer to the industry-average over all countries if a country-industry cluster comprises less than ten observations in OsIRIS.

(3) Goodwill to goodwill and patents $\left(p_{\text {goodwill }}\right)$ : This ratio is also calculated as countryand industry-specific average. Again, this ratio differs across industries rather than across countries; therefore, we also refer to the industry average over all countries for countryindustry clusters with less than ten observations in OsIRIs. ${ }^{16}$

All three ratios are additionally adjusted to account for size effects. To this end, we distinguish between seven different size classes that are defined according to total assets. ${ }^{17}$ Multiplying the

\footnotetext{
${ }^{16}$ The applied industry clusters are reported in Table C.7 in Appendix 2.

${ }^{17}$ We calculate the mean of the three ratios for every size class across all industries and all countries. In addition, we calculate the mean of the three ratios for all corporations. For each size class, the three ratios are then
} 
resultant ratios with the book value of tangible fixed assets $\left(b v_{t f a}\right)$ or intangible fixed assets $\left(b v_{i f a}\right)$ yields our starting values for the book values of each type of asset (see Equations C.54 to C.58).

$$
\begin{gathered}
b v_{\text {land }}=b v_{t f a} \cdot p_{\text {land }} \cdot\left(1-p_{\text {machinery }}\right) \\
b v_{\text {buildings }}=b v_{t f a} \cdot\left(1-p_{\text {land }}\right) \cdot\left(1-p_{\text {machinery }}\right) \\
b v_{\text {machinery }}=b v_{t f a} \cdot p_{\text {machinery }} \\
b v_{\text {patents }}=b v_{\text {ifa }} \cdot\left(1-p_{\text {goodwill }}\right) \\
b v_{\text {goodwill }}=b v_{\text {ifa }} \cdot p_{\text {goodwill }}
\end{gathered}
$$

10.3.1.3 Starting values for the age structure of fixed assets A starting point for the age structure of assets (i.e., the proportion of each type of asset purchased in a specific year) is obtained from a simple company-specific aging model. This model is based on the assumption that, for each company $i$, assets of each type a are purchased in the year of foundation $(t=0$, year of foundation is reported first hand in AmADEus) in the amount of 100.

$$
a c_{i, a, t=0}=100
$$

$a c_{i, a, t}$ refers to the acquisition costs of company $\mathrm{i}$ of asset type a in year $\mathrm{t}$. In subsequent years, new assets of each type are purchased either as a replacement investment or as a capitalwidening investment. Replacement investments are considered for each company and each asset type in the amount of economic depreciation, which is determined linearly over the economic useful life of the asset. The economic useful life is assumed to be fifteen years for goodwill, five years for patents, seven years for machinery and forty years for buildings. The economic useful life of land is assumed to be unlimited.

In addition to replacement investments, capital-widening investments are determined by multiplying the company-specific growth rate $\left(G F_{i}\right.$, as defined in Section C.2.3, minus one) by the remaining economic value of assets. In this respect, the $G F_{i}$ is limited to a value of five, and the remaining economic value of assets is determined as accumulated acquisition costs less accumulated economic depreciation. Altogether, the acquisition costs of company i with regard to asset 
type a in year $t>0\left(a c_{i, a, t}\right)$ are defined as follows:

$$
a c_{i, a, t}=\sum_{x=t-\text { eul }}^{t-1} a c_{i, a, x} \cdot \operatorname{depr} r_{a}^{e c}+\sum_{x=t-\text { eul }}^{t-1}\left(a c_{i, a, x}-\sum_{x=t-\text { eul }}^{t-1} d e p r_{a, x}^{e c}\right) \cdot\left(G F_{i}-1\right)
$$

where eul denotes the economic useful life. This process is repeated until t corresponds to the most recent year with available historical data $(l y)$. In this respect, assets are assumed to leave the company at the end of their economic useful life. We therefore determine the proportion of asset type a acquired in year $\mathrm{t}$ from company i $\left(p_{i, a, t}\right)$ according to the following equation:

$$
p_{i, a, t}=\frac{a c_{i, a, t}}{\sum_{x=t-e u l}^{t} a c_{i, a, x}}
$$

10.3.1.4 Adjustment to ensure conformity with the actual depreciation expense Conformity with the actual depreciation expense is tested by comparing the estimated tax depreciation to the depreciation expense that is reported in Amadeus. To this end, we combine the starting values for the asset structure with regard to both asset type and asset age. Since the ratios for the asset-age clusters (see Equation C.61) refer to acquisition costs rather than to book values, the ratios are adjusted to correspond to book values (resulting in $p(b v)_{i, a, t}$ ).

Depreciation is estimated by multiplying the book value that is estimated for each assettype/asset-age cluster by the corresponding ratio of tax depreciation to book value, which is derived by applying tax regulations of the different countries and years. This determination of tax depreciation (which is assumed to equal book depreciation) is formally expressed in Equation

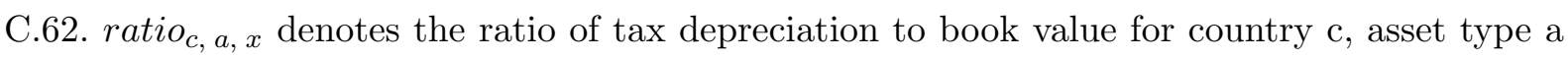
and year $\mathrm{x}$. Index a ranges from one to five and represents the five considered types of assets (land, buildings, machinery, goodwill and patents); $b v_{i, a, t}$ is the book value of asset type a in year $\mathrm{t}$ in company $\mathrm{i}$.

$$
\text { depreciation }_{i, t}=\sum_{a=1}^{5} \sum_{x=t-e u l}^{t} b v_{i, a, t} \cdot p(b v)_{i, a, x} \cdot \operatorname{ratio}_{c(i), a, x}
$$

Depending on whether estimated depreciation exceeds or falls below actual depreciation, the asset-type structure and asset-age structure are adjusted stepwise in one or the other direction. This modification involves the following two adjustments, which are carried out simultaneously.

(1) Modification of the asset-type structure: The ratios of goodwill to goodwill and patents, of land to land and buildings and of machinery to machinery, land and buildings 
are adjusted in one-percent increments. According to the depreciation schedules applied in Germany, patents are depreciated over a shorter useful life than goodwill, whereas the depreciation of machinery is faster than that of land and buildings. This leads, in the case of Germany, to the following modifications (see also Figure C.4):

- If the simulated ratio of depreciation expense to book value falls below the corresponding ratio in AmADEus, the ratio of goodwill to overall intangible fixed assets is reduced by one percent from 40 to 39.6 percent (see Figure C.4), meaning that the share of patents is correspondingly increased to 60.4 percent. In the same manner, the ratios for the different types of tangible fixed assets are modified (land and buildings, 54.45 percent; machinery, 45.55 percent; land to land and buildings, 29.7 percent; buildings to land and buildings, 70.3 percent).

- If the simulated ratio of depreciation expenses to book value exceeds the ratio of actual expenses in AmADEus, the different ratios are modified as follows: goodwill to intangible fixed assets, 40.4 percent; patents to intangible fixed assets, 59.6 percent; land and buildings to tangible fixed assets, 55.55 percent; machinery to tangible fixed assets, 44.45 percent; land to land and buildings, 30.3 percent; and buildings to land and buildings, 69.7 percent.

Figure C.4: Example of asset-type structure determination - initial situation

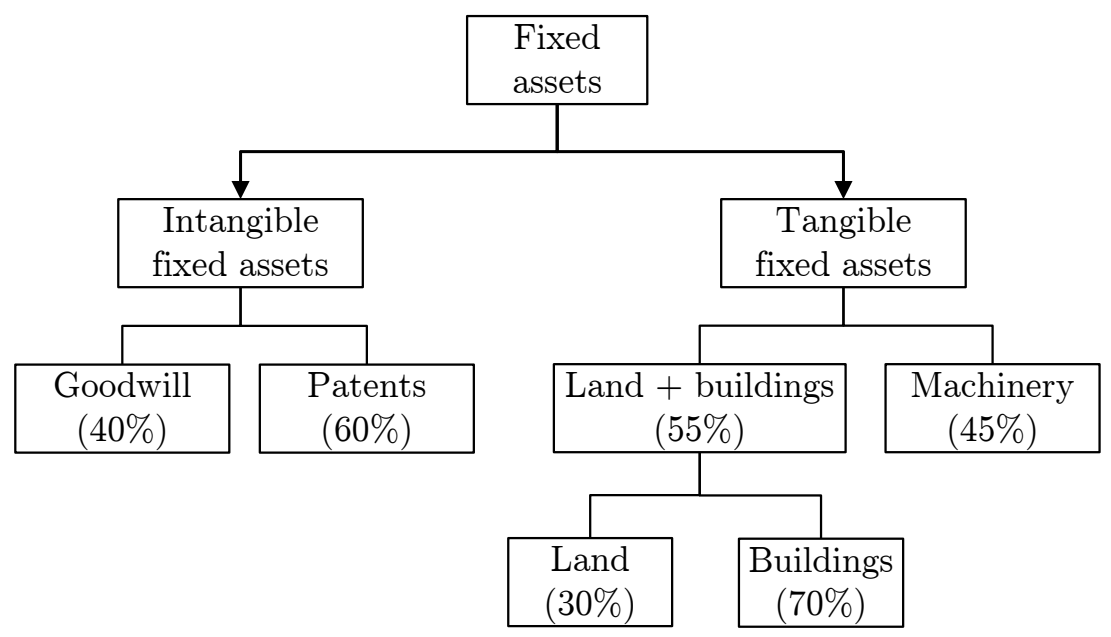

Source: Own diagram.

(2) Modification of the asset-age structure: The age structure of fixed assets is modified in a corresponding manner.

- If the simulated ratio of depreciation expense to book value turns out to be too low, the age of the assets is, on average, underestimated. In this case, the share of "old" 
assets (i. e., assets that are currently in the second half of their expected useful life) is increased by one percent, whereas the share of "new" assets (i. e., assets in the first half of their expected useful life) is decreased correspondingly.

- If the simulated ratio of depreciation expense to book value is above the actual value taken from AmADEUS, modifications are made in the opposite direction.

- If either all the "old" or all the "new" assets are reduced to zero, the remaining part of assets is further split into two halves, and the procedure is repeated.

- Further adjustments are made to avoid a disproportionately high allocation to the clusters of recently acquired assets.

Both steps are repeated simultaneously until the estimated depreciation equals the actual depreciation that is reported in AmADEus. ${ }^{18}$ The resultant weights that are determined for the different asset-type/asset-age classes are multiplied by the overall book values of tangible and intangible fixed assets, and the results are translated into acquisition costs and stored in our database.

\subsubsection{Structure of financial fixed assets and financial revenue}

Financial fixed assets, as well as financial returns, are reported in AMADEUs on an aggregated basis (i. e., without differentiating between equity and debt investments). Differentiating between these two types of financial assets is particularly important, as the resultant interest and dividend payments are treated differently in most countries for tax purposes. Such differentiation is thus required for both the period that is considered for the estimation of tax loss carry-forwards (as described below) and the forecast of future financial revenue (as described in Section C.3.2.8).

To provide an accurate assessment of existing tax loss carry-forwards, past financial revenue as reported in AMADEus must be disaggregated into returns from equity investments in corporations, returns from equity investments in partnerships and returns from debt investments. Available information in general offers three different approaches to disaggregating financial returns. As a first and very simple approach, received dividends could be determined as a fixed proportion of financial returns. Such proportions would have to be determined at least on a per-country basis, given that the capital structure differs internationally and should depend (among other factors) on the applicable tax system. In addition, differentiation according to industry classes would be feasible. The required information could be taken either from the BACH

\footnotetext{
${ }^{18}$ In extreme cases, the iterative process was ended after 5,000 iterations.
} 
database or from country- and industry-specific FDI statistics, neither of which are available for all EU member states, however. In addition, the generality of this approach would diminish the advantages of applying company micro-data and would result in obvious measurement errors for companies with no equity investment (reducing dividends to zero for these companies would result in an underestimation of the average amount of dividends over the whole sample of companies). Based on these shortcomings, we decided against using this first approach.

As a second approach, received dividends may be determined by summing up the profit distributions from all subordinated companies in proportion to the corresponding share in equity. Equation C.63 shows the determination of dividends received by company i in year t. In this respect, $s h_{s}$ denotes the percentage of shareholding in subsidiary s, and $\mathrm{S}$ refers to the number of subsidiaries.

$$
\text { received dividends } s_{i, t}=\sum_{s=1}^{S} s h_{s} \cdot \text { distributed dividend } s_{s, t}
$$

Profit distributions may be estimated based on the available AmADEus data as the (positive) difference between the current year's earnings $\left(\right.$ profit $\left._{s, t}\right)$ and the change in other shareholders' funds $\left(o s f_{s, t}\right)$ of subsidiary s, as shown in Equation C.64:

$$
\text { distributed dividends }_{s, t}=\max \left[0 ; \operatorname{profit}_{s, t}-\Delta o s f_{s, t}\right]
$$

This method provides an accurate assessment of the current year's dividends if other shareholders' funds are affected solely by annual profits or losses and dividend distributions. However, measurement errors arise if capital injections or capital reductions occur. Assuming that these measures are not regularly used, we do not believe that this should distort our estimates of dividends to any significant extent. More important, received dividends are systematically underestimated if AMADEus does not cover all the subsidiaries of all companies (or their balance sheets). Thus, the amount of dividends that is included in financial returns is systematically underestimated in countries for which financial statements are captured only to a small extent (e.g., Germany and Austria). As a third source of measurement error, dividends may be misrepresented if group structures change over time.

Because of these sources of possible measurement errors, we decided to apply a third approach, which is similar to the second one in that it is an indirect approach based on the accounts of the subsidiaries. In contrast to the second approach, however, we disaggregate (in a first step) 
financial assets into equity investments in corporations, equity investments in partnerships and debt investments. To this end, we sum up the products of equity of each subsidiary that is included in AmADEus and the share held by the corresponding parent company. To define the relevant equity of the subsidiary, we refer to subscribed capital (AMADEus item shareholders' funds: capital). For subsidiaries in the legal form of a corporation, subscribed capital should equal the book value of the participation in the balance sheet of the parent (at least in the absence of participation write-downs or capital injections/capital reductions). For subsidiaries in the legal form of a partnership, the participation book value may be increased by retained profits, depending on the corresponding accounting treatment of such participation. Owing to the small amount of participation in partnerships in our sample (only 4.62 percent of all subsidiaries in our sample operate in the legal form of a partnership), this should not significantly distort our estimation.

If shareholders' funds: capital is not available for a specific company-year observation, we proceed as follows:

(1) If capital is not reported for a year but is reported for a previous (or later) year, capital is determined by referring first to the previous year, second to the immediately following year, third to the second previous year and so forth.

(2) If capital is not reported in any year for a company, but total assets are reported in at least one year, we determine capital by multiplying total assets by the capital-to-total-assets ratio, determined with reference to other subsidiaries that are included in AMADEUs. To this end, we refer primarily to the capital-to-assets ratio that is reported for subsidiaries of the same parent company (a) in the same year, (b) in the previous year, (c) in the immediately following year, (d) in the second previous year and so forth. If the capital-toasset ratio is not reported for any of the subsidiaries of the corresponding parent company, we refer, in a similar manner, to all other subsidiaries that are located in the same country.

(3) If capital cannot be determined with either of the two previous approaches, we use operating revenue instead of total assets and determine capital using the same procedure.

Equity investments are allocated to the corresponding shareholders in proportion to the participation rates that are reported in AMADEUs. As the shareholding information is not reported on a yearly basis, we employ shareholding data taken from four different updates of AMADEus and assume that the shareholding structure is unchanged between the updates. In particular, 
we use the shareholding information that is taken from the following updates to allocate equity investments for the corresponding period:

- Update 64 for the years 1994 to 1999

- Update 100 for the years 2000 to 2002

- Update 125 for the years 2003 to 2005

- Update 172 for the years 2006 to 2007

If no shareholding information is available in one of the earlier updates, we refer to the shareholding information from the next update.

Based on this estimate of equity investments, we determine the overall amount of equity investment of company $\mathrm{i}$ in year $\mathrm{t}$ as

$$
\text { shares in subsidiaries }_{i, t}=\sum_{s=1}^{S} s h_{s, t} \cdot \text { capital }_{s, t}
$$

where $s h_{s}$ represents the percentage of shareholding in subsidiary s and S refers to the number of subsidiaries. Debt investments are then determined as the residual value. To differentiate between received dividends and interest returns in our historical data (which is required to accurately determine existing amounts of tax loss carry-forwards), we assume that debt investments yield a return equal to the return of ten-year government bonds in the corresponding EU member state. Dividends then are the residual, i.e., overall financial revenue minus interest payments received. This procedure ensures that the advantages of micro-simulation are maintained by determining company-specific values and that our results are not biased by a systematic underestimation of dividends in certain countries. To avoid an underestimation of received dividends, we determine dividend payments according to the second approach described above and use this result as a minimum value for simulated dividends.

\subsubsection{Existing tax loss carry-forwards}

The amount of tax loss carry-forwards resulting from the pre-simulation period is essential for simulating tax revenue and tax burden. According to the German corporate tax statistics, German corporations reported, in 2004, a positive taxable income before loss-offset of $€ 106$ billion; used loss carry-forwards amounted to $€ 17$ billion. A simulation that completely disregards existing tax loss carry-forwards at the beginning of the simulation period would thus overestimate 
tax revenue by about 19 percent $(=17 /(106-17))$. The aim is therefore to identify existing tax loss carry-forwards at the beginning of the simulation period to provide a realistic simulation of tax revenue and tax burden for subsequent years.

Tax loss carry-forwards cannot be observed directly in published annual accounts and thus have to be estimated by using a direct or an indirect approach. A possible point of reference for a direct determination of existing tax loss carry-forwards could be the ratio of taxation to profit/loss for period that is reported in unconsolidated income statements. If profit/loss for period is greater than zero and either no taxes have been paid or the ratio of taxation (i. e., tax liability) to profit/loss for period is substantially below the statutory tax rate, this could serve as an indication for an existing tax loss carry-forward at the beginning of the period. However, this conclusion is not without doubt, as the calculated tax ratio could also be reduced by tax-free income (such as dividends). Moreover, this method only allows for an assessment of tax loss carry-forwards that do not result in deferred taxes in the income statement. Finally, the method is limited to determining whether a tax loss carry-forward has been used in a specific year, whereas no conclusions can be made regarding the amount of remaining tax loss carry-forwards at the end of that year.

Moreover, profits and losses from previous years that are reported on the balance sheet could serve as a point of reference for a direct determination of tax loss carry-forwards. Possible concerns regarding this approach, however, are that (a) differences between book income and taxable income are not taken into account, (b) restrictions of inter-period tax loss-offset are ignored, (c) the impact of loss-offset through group relief may be ignored (at least if group relief does not require cash transfers) and (d) the amount of book profit/loss carried forward is significantly dependent on the companies' dividend policies. In addition, profits and losses from previous years are not shown as separate items in AMADEUs but are included in the item other shareholders' funds together with (among others) capital and other reserves. For all of these reasons, we assume that defining tax loss carry-forwards to be equal to a negative value for other shareholders' funds would result in a substantial downward bias. This expectation is supported by calculations for German corporations. In 2004, the total of negative values reported in AmADEus for German corporations for the item other shareholders' funds was $€ 964$ million, whereas the corresponding value in the corporate tax statistics amounted to about $€ 418$ billion. $^{19}$

\footnotetext{
${ }^{19}$ These numbers indicate a significant underestimation, even when it is considered that not all German companies are included in our data. Thus, the share of existing loss carry-forwards in our data (measured through the sum of negative values of other shareholders' funds) in comparison to the German corporate tax statistics amounts
} 
For these reasons, we apply an indirect approach to determine tax loss carry-forwards. To this end, we apply loss-offset regulations to a proxy of taxable income that is derived from the financial statements for all years prior to the simulation. The item profit/loss for period (before taxation and considering the significant differences between book income and taxable income) serves as a reference point. Adjustments are made for the tax exemption of dividends (for details, see Section C.10.3.2) as well as the consequences of group taxation systems (for details, see Section C.5.1.3). These adjustments are based on country-specific tax regulations. Other tax features, such as differences between financial and tax accounting or restrictions to the deductibility of interest expenses, are not considered for reasons of simplification. Existing tax losses in the first year of the pre-simulation period are assumed to be zero. For all three steps, the tax regulations of all EU 28 member states are considered.

\subsubsection{Identification of corporate groups' industries}

As a general rule, AmADEus includes primary and secondary NACE codes (NACE rev. 2) that classify the primary and secondary line of business, respectively, that a company is operating in. To identify the main activity of a corporate group, one method is to rely immediately on the NACE code of the parent company. This option, however, is not considered to be useful because, in cases in which the parent serves as a pure holding company, the industry code of the parent company would not reflect the main activity of the subordinated group. Therefore, the group's industry is derived from the NACE codes of all group companies.

The starting point for determining the group industry is the first-level industry section of the group companies that is reported as an alphabetical code in AmADEUs. These companyspecific industry sections are weighted within each group according to the companies' sales (50 percent) and total assets (50 percent). The group's industry is then defined as the industry section with the highest share within the corresponding group. The distribution of industries among corporations and corporate groups is summarized in Table C.7 in Appendix 2.

\section{Appendix 2 - Database in its current version}

In its current version, ASSERT is mainly based on unconsolidated financial data from AMADEUS updates 172 (January 2009) and 125 (February 2005), including financial statements for the years 1994 to 2007. As already mentioned above, ASSERT is restricted to corporations with a legal 
seat in one of the EU 28 member states. After data preparation as described in Section C.10.2, all eligible companies are selected by applying the criteria summarized in Section C.10.1, resulting in the number of simulation companies per country shown in Table C.5 (column 6). In addition, Table C.5 shows the number of corporations in AmADEus with at least the item total assets (column 4). These corporations are used to determine extrapolation factors that are used to estimate tax revenue, as described in Section C.7.1. Both the number of simulation companies and the number of corporations with the item total assets are compared to the number of corporations in the whole population as reported in EuROSTAT $^{20}$ and (for Germany) in the corporate tax statistics for the year $2007^{21}$ (columns 5 and 7). In cases in which no information about the data coverage of EUROSTAT is available, we are not able to report the data coverage of ASSERT and AmADEUs. With regard to the United Kingdom, the data coverage of ASSERT and Amadeus refers to the universe of all corporations (i. e., $1,333,100 / 0.53=2,515,283$ ) rather than to the number reported in EUROSTAT.

Table C.5: Data coverage in Eurostat, Amadeus and ASSERT

\begin{tabular}{lrrrrrr}
\hline Country & $\begin{array}{r}\text { Eurostat/ } \\
\text { Destatis }\end{array}$ & Coverage & AmadEus & $\begin{array}{c}\text { Share of } \\
\text { population }\end{array}$ & $\begin{array}{r}\text { Simulation } \\
\text { companies }\end{array}$ & $\begin{array}{c}\text { Share of } \\
\text { population }\end{array}$ \\
\hline BE & 256,231 & na & 319,716 & na & 26,349 & na \\
BG & 120,345 & $\sim 100 \%$ & 49,877 & $41.44 \%$ & 2,750 & $2.29 \%$ \\
CZ & 154,849 & $\sim 99 \%$ & 85,949 & $55.51 \%$ & 11,829 & $7.64 \%$ \\
DE & 844,380 & $100 \%$ & 473,485 & $56.07 \%$ & 7,328 & $0.87 \%$ \\
DK & 91,751 & $\sim 99 \%$ & 173,211 & $188.78 \%$ & 3,464 & $3.78 \%$ \\
ES & $1,226,027$ & $\sim 99 \%$ & 696,260 & $56.79 \%$ & 214,963 & $17.53 \%$ \\
FI & 118,746 & $\sim 95 \%$ & 79,787 & $67.19 \%$ & 35,718 & $30.08 \%$ \\
FR & $1,144,464$ & na & 467,533 & na & 349,927 & na \\
GB & $1,333,100$ & $\sim 53 \%$ & $1,854,571$ & $73.84 \%$ & 16,112 & $0.64 \%$ \\
GR & na & na & 28,039 & na & 13,105 & na \\
HU & 166,252 & $100 \%$ & 267,387 & $160.83 \%$ & 4,026 & $2.42 \%$ \\
IT & 685,630 & very good & 813,942 & $118.71 \%$ & 215,837 & $31.48 \%$ \\
LU & 19,338 & $98-99 \%$ & 6,896 & $35.66 \%$ & 183 & $0.95 \%$ \\
NL & 221,594 & na & 301,594 & na & 699 & $0.32 \%$ \\
PL & na & na & 57,107 & na & 14,737 & na \\
PT & 312,660 & na & 196,850 & na & 107,449 & na \\
RO & na & na & 124,082 & na & 104,468 & na \\
SE & 252,498 & $\sim 99 \%$ & 228,004 & $90.30 \%$ & 115,383 & $45.70 \%$ \\
SK & 75,280 & $\sim 99 \%$ & 13,594 & $18.06 \%$ & 2,694 & $3.58 \%$ \\
\hline Total & $7,359,151$ & & $6,237,884$ & & $1,247,021$ & \\
\hline & & & & & &
\end{tabular}

Table C.5 shows that the data coverage in Amadeus (when at least the item total assets

\footnotetext{
${ }^{20} \mathrm{URL}$ : http://epp.eurostat.ec.europa.eu/portal/page/portal/european_business/special_sbs_topics/business_demography and, for information on coverage, http://epp.eurostat.ec.europa.eu/cache/ITY_SDDS/Annexes/bd_ esms_an1.pdf

${ }^{21}$ Destatis, 2011.
} 
is available) is between 18 and 188 percent. Even though the data coverage is not close to 100 percent in every country, we do not expect this to distort our (extrapolated) results to any significant extent. First, the coverage refers only to the number of companies rather than to the amount of profits or losses. As (especially in the case of Germany) large companies are overrepresented in AMADEUs, the coverage of profits and losses is much higher than the coverage of corporations, and missing data on micro-enterprises should not have a large impact on estimated tax revenue. The "excess coverage" in the cases of Denmark, Hungary and Italy is most likely attributable to imprecise or unequal classifications of industry and legal form in Eurostat. ${ }^{22}$

The overall sample of simulation companies consists of 1,247,021 corporations from 19 different EU member states. Companies residing in the remaining nine EU member states are excluded for different reasons. Whereas no data on Croatian, Cypriot and Slovenian companies are available in AmAdeus, Estonian companies are not covered because the available data do not allow for an assessment of the asset structure. In addition (and as pointed out in Sections C.3.2.2 and C.3.2.4), at least 180 three-year datasets for the generation of bins of comparable companies have to be available for each country to apply the described forecasting approach. This requirement is not met by Austria, Ireland, Lithuania and Malta, as shown in Table C.6. In the case of Latvia, more than 180 three-year datasets are available, but the number of simulation companies for Latvia is not comprehensive enough to guarantee a realistic estimation of the revenue consequences of tax reforms. Table C.6 shows the number of three-year datasets per country; rows with gray background indicate that these countries are not included in the simulation procedure. Table C.7 presents the distribution of industries within the simulation companies.

\footnotetext{
${ }^{22}$ See also Poppe, 2007, page 91.
} 
Table C.6: Three-year datasets available for the generation of bins (comparable companies)

\begin{tabular}{|c|c|c|c|c|c|c|c|}
\hline State & $\begin{array}{r}2000 \\
-2002\end{array}$ & $\begin{array}{r}2001 \\
-2003\end{array}$ & $\begin{array}{r}2002 \\
-2004\end{array}$ & $\begin{array}{r}2003 \\
-2005\end{array}$ & $\begin{array}{r}2004 \\
-2006\end{array}$ & $\begin{array}{r}2005 \\
-2007\end{array}$ & Total \\
\hline AT & - & - & - & 4 & 41 & 106 & (151) \\
\hline $\mathrm{BE}$ & 15,437 & 16,469 & 18,071 & 19,158 & 19,621 & 19,797 & 108,553 \\
\hline $\mathrm{BG}$ & 2,450 & 2,947 & 3,539 & 5,574 & 6,042 & 7,998 & 28,550 \\
\hline CY & - & - & - & - & - & - & - \\
\hline CZ & 2,710 & 3,744 & 9,017 & 14,797 & 16,073 & 8,137 & 54,478 \\
\hline $\mathrm{DE}$ & 837 & 1,963 & 3,496 & 5,907 & 6,845 & 4,439 & 23,487 \\
\hline DK & - & 25 & 105 & 2,036 & 2,435 & 2,421 & 7,022 \\
\hline $\mathrm{EE}$ & 9,170 & 5,565 & 5,589 & 5,671 & 7,178 & 9,872 & $(43,045)$ \\
\hline ES & 173,910 & 215,314 & 245,910 & 273,749 & 272,492 & 180,572 & $1,361,947$ \\
\hline FI & 21,522 & 23,711 & 24,708 & 26,904 & 28,840 & 28,773 & 154,458 \\
\hline FR & 263,675 & 284,276 & 306,167 & 321,515 & 325,136 & 291,111 & $1,791,880$ \\
\hline GB & 6,998 & 7,212 & 8,096 & 8,754 & 9,853 & 9,855 & 50,768 \\
\hline GR & 10,842 & 11,648 & 11,968 & 12,760 & 13,231 & 13,222 & 73,671 \\
\hline HR & - & - & - & - & - & - & - \\
\hline $\mathrm{HU}$ & 20 & 22 & 75 & 465 & 5,365 & 3,186 & 9,133 \\
\hline IE & - & - & - & - & - & - & - \\
\hline IT & 43,614 & 67,078 & 99,836 & 96,611 & 172,982 & 169,831 & 649,952 \\
\hline $\mathrm{LU}$ & 33 & 54 & 87 & 197 & 278 & 119 & 768 \\
\hline LT & - & - & - & - & - & - & - \\
\hline LV & 24 & 48 & 58 & 71 & 67 & 67 & (335) \\
\hline MT & - & - & - & - & - & - & - \\
\hline NL & 242 & 281 & 476 & 599 & 666 & 451 & 2,715 \\
\hline PL & 3,231 & 4,585 & 6,366 & 7,953 & 8,411 & 8,235 & 38,781 \\
\hline $\mathrm{PT}$ & 8,674 & 10,280 & 16,550 & 25,012 & 31,000 & 90,706 & 182,222 \\
\hline $\mathrm{RO}$ & 11,279 & 15,656 & 19,366 & 28,310 & 44,457 & 71,871 & 190,939 \\
\hline $\mathrm{SE}$ & 69,540 & 74,403 & 80,472 & 87,993 & 94,827 & 99,915 & 507,150 \\
\hline SI & $\begin{array}{ll}- \\
-\end{array}$ & - & - & - & - & 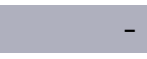 & \\
\hline SK & 377 & 610 & 1,006 & 1,932 & 2,389 & 1,282 & 7,596 \\
\hline
\end{tabular}




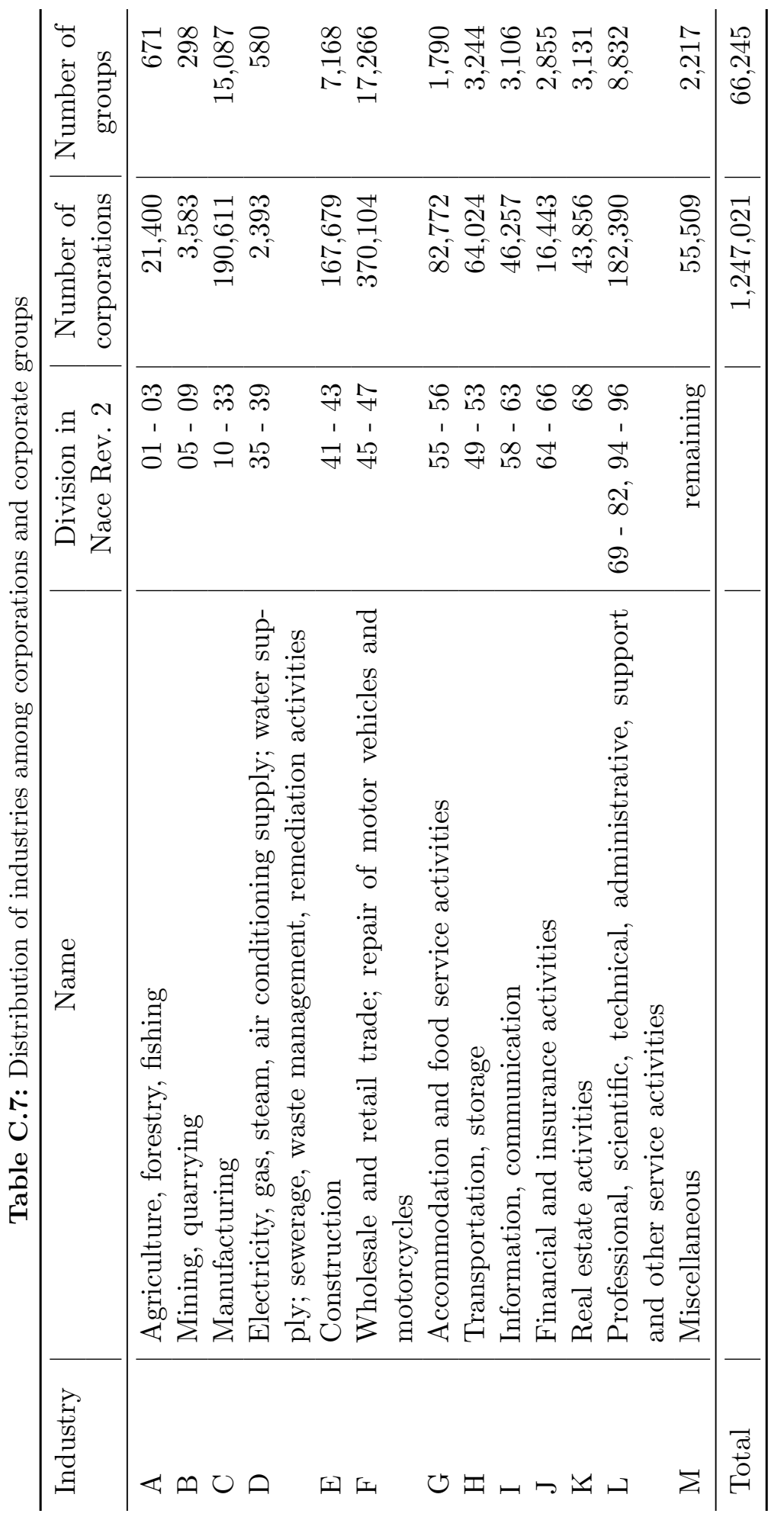




\section{Appendix 3 - Accuracy of the model - country tables}

Table C.8: Forecasting quality of ASSERT - Belgium

\begin{tabular}{|c|c|c|c|c|}
\hline Year & & 2008 & 2009 & 2010 \\
\hline Total assets & Number of observations & 10,986 & 10,690 & 3,897 \\
\hline \multirow[t]{3}{*}{ ASSERT } & Mean & 48,306 & 48,961 & 75,087 \\
\hline & Median & 4,427 & 4,483 & 5,059 \\
\hline & Standard deviation & 573,481 & 576,276 & 857,898 \\
\hline \multirow[t]{3}{*}{ Amadeus } & Mean & 61,363 & 64,007 & 114,189 \\
\hline & Median & 4,761 & 4,720 & 5,422 \\
\hline & Standard deviation & 828,398 & 891,081 & $1,428,689$ \\
\hline \multirow[t]{2}{*}{ Comparison } & Correlation & 0.922 & 0.915 & 0.930 \\
\hline & $\mathrm{P}$-value of two-tailed t-test & 0.000 & 0.000 & 0.001 \\
\hline Liabilities & Number of observations & 10,986 & 10,690 & 3,897 \\
\hline \multirow{3}{*}{ ASSERT } & Mean & 26,585 & 29,883 & 51,127 \\
\hline & Median & 2,472 & 2,587 & 2,907 \\
\hline & Standard deviation & 379,297 & 415,181 & 713,996 \\
\hline \multirow[t]{3}{*}{ Amadeus } & Mean & 30,900 & 31,086 & 51,501 \\
\hline & Median & 2,643 & 2,515 & 2,713 \\
\hline & Standard deviation & 422,419 & 431,860 & 671,085 \\
\hline \multirow[t]{2}{*}{ Comparison } & Correlation & 0.917 & 0.913 & 0.920 \\
\hline & $\mathrm{P}$-value of two-tailed t-test & 0.008 & 0.483 & 0.934 \\
\hline Depreciation & Number of observations & 10,971 & 10,617 & 3,863 \\
\hline \multirow[t]{3}{*}{ ASSERT } & Mean & 874 & 956 & 1,204 \\
\hline & Median & 119 & 130 & 167 \\
\hline & Standard deviation & 6,650 & 7,087 & 7,440 \\
\hline \multirow[t]{3}{*}{ Amadeus } & Mean & 895 & 979 & 1,138 \\
\hline & Median & 120 & 126 & 146 \\
\hline & Standard deviation & 7,040 & 8,285 & 7,941 \\
\hline \multirow[t]{2}{*}{ Comparison } & Correlation & 0.965 & 0.888 & 0.885 \\
\hline & P-value of two-tailed t-test & 0.241 & 0.548 & 0.274 \\
\hline Operating profit/loss & Number of observations & 10,986 & 10,690 & 3,897 \\
\hline \multirow[t]{3}{*}{ ASSERT } & Mean & 1,678 & 1,796 & 2,091 \\
\hline & Median & 231 & 220 & 266 \\
\hline & Standard deviation & 19,540 & 21,223 & 17,903 \\
\hline \multirow[t]{3}{*}{ Amadeus } & Mean & 1,477 & 1,266 & 2,054 \\
\hline & Median & 201 & 152 & 240 \\
\hline & Standard deviation & 15,585 & 18,893 & 20,492 \\
\hline \multirow[t]{2}{*}{ Comparison } & Correlation & 0.747 & 0.711 & 0.751 \\
\hline & P-value of two-tailed t-test & 0.106 & 0.000 & 0.865 \\
\hline
\end{tabular}


Table C.9: Forecasting quality of ASSERT - Czech Republic

\begin{tabular}{|c|c|c|c|c|}
\hline Year & & 2008 & 2009 & 2010 \\
\hline Total assets & Number of observations & 6,178 & 5,571 & 1,061 \\
\hline \multirow[t]{3}{*}{ ASSERT } & Mean & 11,157 & 12,392 & 15,049 \\
\hline & Median & 1,901 & 2,173 & 1,930 \\
\hline & Standard deviation & 62,281 & 72,816 & 81,366 \\
\hline \multirow[t]{3}{*}{ Amadeus } & Mean & 10,946 & 11,705 & 14,596 \\
\hline & Median & 2,006 & 2,085 & 1,747 \\
\hline & Standard deviation & 55,933 & 63,992 & 74,249 \\
\hline \multirow[t]{2}{*}{ Comparison } & Correlation & 0.927 & 0.925 & 0,973 \\
\hline & $\mathrm{P}$-value of two-tailed t-test & 0.481 & 0.065 & 0.446 \\
\hline Liabilities & Number of observations & 6,180 & 5,572 & 1,061 \\
\hline \multirow[t]{3}{*}{ ASSERT } & Mean & 5,845 & 6,738 & 7,230 \\
\hline & Median & 1,001 & 1,178 & 1,112 \\
\hline & Standard deviation & 35,327 & 39,097 & 32,902 \\
\hline \multirow[t]{3}{*}{ AMADEUS } & Mean & 5,306 & 5,299 & 6,202 \\
\hline & Median & 900 & 876 & 701 \\
\hline & Standard deviation & 32,602 & 32,036 & 30,880 \\
\hline \multirow[t]{2}{*}{ Comparison } & Correlation & 0.932 & 0.846 & 0.940 \\
\hline & $\mathrm{P}$-value of two-tailed t-test & 0.001 & 0.000 & 0.003 \\
\hline Depreciation & Number of observations & 6,124 & 5,500 & 1,050 \\
\hline \multirow[t]{3}{*}{ ASSERT } & Mean & 654 & 784 & 1,046 \\
\hline & Median & 58 & 69 & 72 \\
\hline & Standard deviation & 7,986 & 8,460 & 8,912 \\
\hline \multirow[t]{3}{*}{ Amadeus } & Mean & 619 & 670 & 839 \\
\hline & Median & 53 & 62 & 60 \\
\hline & Standard deviation & 8,947 & 8,145 & 7,420 \\
\hline \multirow[t]{2}{*}{ Comparison } & Correlation & 0.976 & 0.943 & 0.980 \\
\hline & $\mathrm{P}$-value of two-tailed t-test & 0.194 & 0.003 & 0.003 \\
\hline Operating profit/loss & Number of observations & 6,180 & 5,572 & 1,061 \\
\hline \multirow[t]{3}{*}{ ASSERT } & Mean & 1,007 & 801 & 1,298 \\
\hline & Median & 140 & 115 & 131 \\
\hline & Standard deviation & 7,042 & 7,010 & 9,085 \\
\hline \multirow{3}{*}{ Amadeus } & Mean & 832 & 686 & 1,011 \\
\hline & Median & 130 & 83 & 109 \\
\hline & Standard deviation & 6,564 & 7,169 & 5,736 \\
\hline \multirow[t]{2}{*}{ Comparison } & Correlation & 0.740 & 0.213 & 0.658 \\
\hline & $\mathrm{P}$-value of two-tailed t-test & 0.005 & 0.335 & 0.172 \\
\hline
\end{tabular}


Table C.10: Forecasting quality of ASSERT - Finland

\begin{tabular}{|c|c|c|c|c|}
\hline Year & & 2008 & 2009 & 2010 \\
\hline Total assets & Number of observations & 10,065 & 9,839 & 6,825 \\
\hline \multirow[t]{3}{*}{ ASSERT } & Mean & 11,811 & 11,822 & 14,215 \\
\hline & Median & 1,132 & 1,147 & 1,079 \\
\hline & Standard deviation & 229,775 & 232,247 & 278,152 \\
\hline \multirow[t]{3}{*}{ AMADEUS } & Mean & 14,096 & 13,957 & 18,083 \\
\hline & Median & 1,340 & 1,357 & 1,357 \\
\hline & Standard deviation & 274,123 & 262,048 & 326,468 \\
\hline \multirow[t]{2}{*}{ Comparison } & Correlation & 0.902 & 0.900 & 0.891 \\
\hline & $\mathrm{P}$-value of two-tailed t-test & 0.055 & 0.064 & 0.032 \\
\hline Liabilities & Number of observations & 10,065 & 9,839 & 6,825 \\
\hline \multirow[t]{3}{*}{ ASSERT } & Mean & 6,928 & 7,050 & 8,098 \\
\hline & Median & 681 & 733 & 707 \\
\hline & Standard deviation & 118,399 & 117,702 & 137,354 \\
\hline \multirow[t]{3}{*}{ AMADEUS } & Mean & 7,633 & 7,417 & 9,157 \\
\hline & Median & 627 & 607 & 610 \\
\hline & Standard deviation & 138,006 & 129,234 & 158,405 \\
\hline \multirow[t]{2}{*}{ Comparison } & Correlation & 0.921 & 0.916 & 0.869 \\
\hline & $\mathrm{P}$-value of two-tailed t-test & 0.195 & 0.483 & 0.265 \\
\hline Depreciation & Number of observations & 9,985 & 9,700 & 6,694 \\
\hline \multirow[t]{3}{*}{ ASSERT } & Mean & 324 & 321 & 381 \\
\hline & Median & 44 & 41 & 45 \\
\hline & Standard deviation & 5,508 & 5,709 & 6,978 \\
\hline \multirow[t]{3}{*}{ Amadeus } & Mean & 332 & 348 & 314 \\
\hline & Median & 44 & 44 & 43 \\
\hline & Standard deviation & 6,642 & 6,808 & 4,393 \\
\hline \multirow[t]{2}{*}{ Comparison } & Correlation & 0.958 & 0.949 & 0.672 \\
\hline & $\mathrm{P}$-value of two-tailed t-test & 0.724 & 0.233 & 0.295 \\
\hline Operating profit/loss & Number of observations & 10,065 & 9,839 & 6,825 \\
\hline \multirow[t]{3}{*}{ ASSERT } & Mean & 358 & 263 & 445 \\
\hline & Median & 123 & 104 & 113 \\
\hline & Standard deviation & 13,882 & 9,292 & 5,785 \\
\hline \multirow[t]{3}{*}{ Amadeus } & Mean & 448 & 293 & 620 \\
\hline & Median & 131 & 96 & 112 \\
\hline & Standard deviation & 10,994 & 8,070 & 9,403 \\
\hline \multirow[t]{2}{*}{ Comparison } & Correlation & 0.893 & 0.308 & -0.142 \\
\hline & $\mathrm{P}$-value of two-tailed t-test & 0.161 & 0.768 & 0.217 \\
\hline
\end{tabular}


Table C.11: Forecasting quality of ASSERT - France

\begin{tabular}{|c|c|c|c|c|}
\hline Year & & 2008 & 2009 & 2010 \\
\hline Total assets & Number of observations & 111,999 & 104,469 & 34,738 \\
\hline \multirow[t]{3}{*}{ ASSERT } & Mean & 8,376 & 8,357 & 7,403 \\
\hline & Median & 1,288 & 1,284 & 1,115 \\
\hline & Standard deviation & 147,750 & 150,887 & 103,069 \\
\hline \multirow[t]{3}{*}{ Amadeus } & Mean & 9,132 & 8,914 & 7,772 \\
\hline & Median & 1,403 & 1,401 & 1,286 \\
\hline & Standard deviation & 271,724 & 274,717 & 114,535 \\
\hline \multirow{2}{*}{ Comparison } & Correlation & 0.950 & 0.953 & 0.935 \\
\hline & $\mathrm{P}$-value of two-tailed t-test & 0.069 & 0.194 & 0.092 \\
\hline Liabilities & Number of observations & 112,000 & 104,469 & 34,738 \\
\hline \multirow[t]{3}{*}{ ASSERT } & Mean & 5,378 & 5,478 & 4,784 \\
\hline & Median & 756 & 763 & 661 \\
\hline & Standard deviation & 77,834 & 79,835 & 56,319 \\
\hline \multirow[t]{3}{*}{ Amadeus } & Mean & 5,570 & 5,287 & 4,564 \\
\hline & Median & 814 & 783 & 696 \\
\hline & Standard deviation & 117,982 & 119,472 & 78,092 \\
\hline \multirow{2}{*}{ Comparison } & Correlation & 0.935 & 0.932 & 0.862 \\
\hline & $\mathrm{P}$-value of two-tailed t-test & 0.227 & 0.250 & 0.318 \\
\hline Depreciation & Number of observations & 111,597 & 103,680 & 34,426 \\
\hline \multirow[t]{3}{*}{ ASSERT } & Mean & 239 & 245 & 235 \\
\hline & Median & 32 & 33 & 33 \\
\hline & Standard deviation & 4,769 & 4,902 & 4,187 \\
\hline \multirow[t]{3}{*}{ Amadeus } & Mean & 240 & 235 & 207 \\
\hline & Median & 32 & 34 & 32 \\
\hline & Standard deviation & 4,083 & 3,737 & 2,645 \\
\hline \multirow[t]{2}{*}{ Comparison } & Correlation & 0.700 & 0.684 & 0.721 \\
\hline & $\mathrm{P}$-value of two-tailed t-test & 0.867 & 0.336 & 0.074 \\
\hline Operating profit/loss & Number of observations & 112,000 & 104,469 & 34,738 \\
\hline \multirow[t]{3}{*}{ ASSERT } & Mean & 566 & 538 & 610 \\
\hline & Median & 98 & 86 & 84 \\
\hline & Standard deviation & 8,908 & 12,557 & 15,521 \\
\hline \multirow[t]{3}{*}{ Amadeus } & Mean & 489 & 383 & 453 \\
\hline & Median & 96 & 77 & 90 \\
\hline & Standard deviation & 7,099 & 5,509 & 5,951 \\
\hline \multirow[t]{2}{*}{ Comparison } & Correlation & 0.522 & 0.280 & 0.416 \\
\hline & $\mathrm{P}$-value of two-tailed t-test & 0.001 & 0.000 & 0.039 \\
\hline
\end{tabular}


Table C.12: Forecasting quality of ASSERT - Germany

\begin{tabular}{|c|c|c|c|c|}
\hline Year & & 2008 & 2009 & 2010 \\
\hline Total assets & Number of observations & 4,472 & 4,214 & 908 \\
\hline \multirow[t]{3}{*}{ ASSERT } & Mean & 110,253 & 108,933 & 229,128 \\
\hline & Median & 14,785 & 14,538 & 16,107 \\
\hline & Standard deviation & 686,911 & 657,811 & $1,243,335$ \\
\hline \multirow[t]{3}{*}{ Amadeus } & Mean & 120,937 & 118,685 & 275,149 \\
\hline & Median & 16,404 & 15,317 & 17,618 \\
\hline & Standard deviation & 729,638 & 745,345 & $1,592,774$ \\
\hline \multirow[t]{2}{*}{ Comparison } & Correlation & 0.975 & 0.972 & 0.956 \\
\hline & $\mathrm{P}$-value of two-tailed t-test & 0.000 & 0.001 & 0.011 \\
\hline Liabilities & Number of observations & 4,472 & 4,214 & 908 \\
\hline \multirow[t]{3}{*}{ ASSERT } & Mean & 69,317 & 67,646 & 146,258 \\
\hline & Median & 8,691 & 7,728 & 9,422 \\
\hline & Standard deviation & 445,057 & 413,704 & 790,483 \\
\hline \multirow[t]{3}{*}{ Amadeus } & Mean & 76,688 & 72,654 & 165,376 \\
\hline & Median & 9,105 & 8,372 & 9,465 \\
\hline & Standard deviation & 489,005 & 477,917 & 991,933 \\
\hline \multirow{2}{*}{ Comparison } & Correlation & 0.946 & 0.935 & 0.936 \\
\hline & $\mathrm{P}$-value of two-tailed t-test & 0.002 & 0.060 & 0.076 \\
\hline Depreciation & Number of observations & 4,408 & 4,176 & 896 \\
\hline \multirow{3}{*}{ ASSERT } & Mean & 4,111 & 3,298 & 5,888 \\
\hline & Median & 453 & 385 & 381 \\
\hline & Standard deviation & 25,279 & 19,809 & 38,020 \\
\hline \multirow[t]{3}{*}{ Amadeus } & Mean & 4,080 & 3,786 & 6,809 \\
\hline & Median & 462 & 451 & 441 \\
\hline & Standard deviation & 22,988 & 21,807 & 44,207 \\
\hline \multirow[t]{2}{*}{ Comparison } & Correlation & 0.980 & 0.973 & 0.988 \\
\hline & $\mathrm{P}$-value of two-tailed t-test & 0.691 & 0.000 & 0.002 \\
\hline Operating profit/loss & Number of observations & 4,416 & 4,191 & 902 \\
\hline \multirow[t]{3}{*}{ ASSERT } & Mean & 5,847 & 5,095 & 11,445 \\
\hline & Median & 824 & 676 & 1,199 \\
\hline & Standard deviation & 32,666 & 27,888 & 51,485 \\
\hline \multirow[t]{3}{*}{ Amadeus } & Mean & 5,190 & 4,633 & 10,814 \\
\hline & Median & 688 & 479 & 745 \\
\hline & Standard deviation & 38,655 & 37,771 & 60,711 \\
\hline \multirow[t]{2}{*}{ Comparison } & Correlation & 0.613 & 0.741 & 0.767 \\
\hline & $\mathrm{P}$-value of two-tailed t-test & 0.170 & 0.238 & 0.629 \\
\hline
\end{tabular}


Table C.13: Forecasting quality of ASSERT - Italy

\begin{tabular}{|c|c|c|c|c|}
\hline Year & & 2008 & 2009 & 2010 \\
\hline Total assets & Number of observations & 98,124 & 94,377 & 21,333 \\
\hline \multirow[t]{3}{*}{ ASSERT } & Mean & 7,557 & 7,849 & 9,220 \\
\hline & Median & 2,114 & 2,180 & 2,139 \\
\hline & Standard deviation & 66,016 & 67,201 & 104,329 \\
\hline \multirow[t]{3}{*}{ Amadeus } & Mean & 8,195 & 8,321 & 10,045 \\
\hline & Median & 2,368 & 2,392 & 2,420 \\
\hline & Standard deviation & 65,511 & 77,712 & 139,090 \\
\hline \multirow{2}{*}{ Comparison } & Correlation & 0.967 & 0.945 & 0.951 \\
\hline & $\mathrm{P}$-value of two-tailed t-test & 0.000 & 0.000 & 0.019 \\
\hline Liabilities & Number of observations & 98,124 & 94,377 & 21,333 \\
\hline \multirow{3}{*}{ ASSERT } & Mean & 5,522 & 5,711 & 6,464 \\
\hline & Median & 1,569 & 1,593 & 1,491 \\
\hline & Standard deviation & 47,608 & 48,454 & 72,946 \\
\hline \multirow{3}{*}{ Amadeus } & Mean & 5,681 & 5,659 & 6,526 \\
\hline & Median & 1,692 & 1,690 & 1,611 \\
\hline & Standard deviation & 45,285 & 49,031 & 83,776 \\
\hline \multirow{2}{*}{ Comparison } & Correlation & 0.942 & 0.928 & 0.923 \\
\hline & $\mathrm{P}$-value of two-tailed t-test & 0.002 & 0.384 & 0.781 \\
\hline Depreciation & Number of observations & 97,626 & 93,670 & 21,223 \\
\hline \multirow[t]{3}{*}{ ASSERT } & Mean & 256 & 278 & 372 \\
\hline & Median & 54 & 56 & 63 \\
\hline & Standard deviation & 3,227 & 3,569 & 6,122 \\
\hline \multirow[t]{3}{*}{ Amadeus } & Mean & 251 & 261 & 304 \\
\hline & Median & 54 & 57 & 57 \\
\hline & Standard deviation & 3,071 & 3,169 & 3,863 \\
\hline \multirow[t]{2}{*}{ Comparison } & Correlation & 0.961 & 0.882 & 0.934 \\
\hline & $\mathrm{P}$-value of two-tailed t-test & 0.095 & 0.002 & 0.001 \\
\hline Operating profit/loss & Number of observations & 98,124 & 94,377 & 21,333 \\
\hline \multirow[t]{3}{*}{ ASSERT } & Mean & 355 & 298 & 391 \\
\hline & Median & 92 & 818 & 93 \\
\hline & Standard deviation & 4,051 & 4,005 & 6,408 \\
\hline \multirow[t]{3}{*}{ Amadeus } & Mean & 267 & 220 & 346 \\
\hline & Median & 94 & 72 & 84 \\
\hline & Standard deviation & 17,951 & 4,536 & 12,337 \\
\hline \multirow[t]{2}{*}{ Comparison } & Correlation & 0.219 & 0.573 & 0.595 \\
\hline & $\mathrm{P}$-value of two-tailed t-test & 0.118 & 0.000 & 0.513 \\
\hline
\end{tabular}


Table C.14: Forecasting quality of ASSERT - Poland

\begin{tabular}{|c|c|c|c|c|}
\hline Year & & 2008 & 2009 & 2010 \\
\hline Total assets & Number of observations & 9,915 & 9,200 & 1,082 \\
\hline \multirow[t]{3}{*}{ ASSERT } & Mean & 8,218 & 9,332 & 12,783 \\
\hline & Median & 1,986 & 2,331 & 2,876 \\
\hline & Standard deviation & 45,199 & 48,180 & 55,790 \\
\hline \multirow[t]{3}{*}{ Amadeus } & Mean & 8,737 & 9,320 & 12,546 \\
\hline & Median & 2,029 & 2,161 & 2,499 \\
\hline & Standard deviation & 49,106 & 54,375 & 66,493 \\
\hline \multirow[t]{2}{*}{ Comparison } & Correlation & 0.972 & 0.933 & 0.923 \\
\hline & $\mathrm{P}$-value of two-tailed t-test & 0.000 & 0.956 & 0.765 \\
\hline Liabilities & Number of observations & 9,913 & 9,198 & 1,082 \\
\hline \multirow[t]{3}{*}{ ASSERT } & Mean & 4,596 & 5,679 & 7,958 \\
\hline & Median & 1,055 & 1,302 & 1,678 \\
\hline & Standard deviation & 25,039 & 35,405 & 38,242 \\
\hline \multirow[t]{3}{*}{ AMADEUS } & Mean & 4,688 & 4,792 & 5,909 \\
\hline & Median & 911 & 904 & 961 \\
\hline & Standard deviation & 27,759 & 29,018 & 37,918 \\
\hline \multirow[t]{2}{*}{ Comparison } & Correlation & 0.909 & 0.717 & 0.903 \\
\hline & $\mathrm{P}$-value of two-tailed t-test & 0.429 & 0.001 & 0.000 \\
\hline Depreciation & Number of observations & 9,784 & 9,030 & 1,045 \\
\hline \multirow[t]{3}{*}{ ASSERT } & Mean & 432 & 505 & 601 \\
\hline & Median & 62 & 74 & 98 \\
\hline & Standard deviation & 5,115 & 5,504 & 4,210 \\
\hline \multirow[t]{3}{*}{ Amadeus } & Mean & 416 & 454 & 492 \\
\hline & Median & 59 & 66 & 69 \\
\hline & Standard deviation & 4,625 & 5,054 & 3,852 \\
\hline \multirow[t]{2}{*}{ Comparison } & Correlation & 0.980 & 0.992 & 0.982 \\
\hline & $\mathrm{P}$-value of two-tailed t-test & 0.155 & 0.000 & 0.000 \\
\hline Operating profit/loss & Number of observations & 9,906 & 9,191 & 1,082 \\
\hline \multirow[t]{3}{*}{ ASSERT } & Mean & 905 & 880 & 1,244 \\
\hline & Median & 180 & 182 & 278 \\
\hline & Standard deviation & 7,852 & 6,312 & 5,179 \\
\hline \multirow[t]{3}{*}{ Amadeus } & Mean & 870 & 808 & 1,007 \\
\hline & Median & 163 & 135 & 180 \\
\hline & Standard deviation & 7,596 & 7,201 & 4,869 \\
\hline \multirow{2}{*}{ Comparison } & Correlation & 0.855 & 0.702 & 0.343 \\
\hline & $\mathrm{P}$-value of two-tailed t-test & 0.400 & 0.191 & 0.176 \\
\hline
\end{tabular}


Table C.15: Forecasting quality of ASSERT - Spain

\begin{tabular}{|c|c|c|c|c|}
\hline Year & & 2008 & 2009 & 2010 \\
\hline Total assets & Number of observations & 72,304 & 67,375 & 292 \\
\hline \multirow[t]{3}{*}{ ASSERT } & Mean & 9,824 & 10,697 & 288,772 \\
\hline & Median & 2,090 & 2,241 & 24,732 \\
\hline & Standard deviation & 132,216 & 137,361 & $1,095,405$ \\
\hline \multirow[t]{3}{*}{ Amadeus } & Mean & 9,599 & 9,634 & 278,630 \\
\hline & Median & 2,056 & 2,050 & 21,102 \\
\hline & Standard deviation & 131,605 & 122,712 & $1,007,174$ \\
\hline \multirow{2}{*}{ Comparison } & Correlation & 0.966 & 0.953 & 0.902 \\
\hline & $\mathrm{P}$-value of two-tailed t-test & 0.078 & 0.000 & 0.714 \\
\hline Liabilities & Number of observations & 72,304 & 67,375 & 292 \\
\hline \multirow{3}{*}{ ASSERT } & Mean & 6,491 & 7,288 & 204,682 \\
\hline & Median & 1,194 & 1,327 & 13,572 \\
\hline & Standard deviation & 94,913 & 105,589 & 920,559 \\
\hline \multirow[t]{3}{*}{ Amadeus } & Mean & 6,145 & 5,948 & 172,350 \\
\hline & Median & 1,078 & 1,020 & 11,367 \\
\hline & Standard deviation & 100,033 & 86,091 & 661,951 \\
\hline \multirow{2}{*}{ Comparison } & Correlation & 0.954 & 0.907 & 0.826 \\
\hline & $\mathrm{P}$-value of two-tailed t-test & 0.002 & 0.000 & 0.296 \\
\hline Depreciation & Number of observations & 71,109 & 65,848 & 291 \\
\hline \multirow{3}{*}{ ASSERT } & Mean & 385 & 450 & 18,832 \\
\hline & Median & 55 & 70 & 646 \\
\hline & Standard deviation & 13,402 & 15,336 & 132,390 \\
\hline \multirow[t]{3}{*}{ Amadeus } & Mean & 295 & 303 & 11,929 \\
\hline & Median & 44 & 44 & 287 \\
\hline & Standard deviation & 8,358 & 8,326 & 71,217 \\
\hline \multirow[t]{2}{*}{ Comparison } & Correlation & 0.951 & 0.959 & 0.953 \\
\hline & $\mathrm{P}$-value of two-tailed t-test & 0.000 & 0.000 & 0.085 \\
\hline Operating profit/loss & Number of observations & 72,295 & 67,366 & 292 \\
\hline \multirow[t]{3}{*}{ ASSERT } & Mean & 565 & 452 & 8,790 \\
\hline & Median & 85 & 72 & 506 \\
\hline & Standard deviation & 15,586 & 11,469 & 120,919 \\
\hline \multirow[t]{3}{*}{ Amadeus } & Mean & 550 & 439 & 25,557 \\
\hline & Median & 85 & 59 & 438 \\
\hline & Standard deviation & 22,318 & 21,847 & 170,277 \\
\hline \multirow[t]{2}{*}{ Comparison } & Correlation & 0.848 & 0.509 & 0.470 \\
\hline & $\mathrm{P}$-value of two-tailed t-test & 0.745 & 0.858 & 0.067 \\
\hline
\end{tabular}


Table C.16: Forecasting quality of ASSERT - Sweden

\begin{tabular}{|c|c|c|c|c|}
\hline Year & & 2008 & 2009 & 2010 \\
\hline Total assets & Number of observations & 32,099 & 31,998 & 21,182 \\
\hline \multirow[t]{3}{*}{ ASSERT } & Mean & 10,511 & 11,343 & 10,622 \\
\hline & Median & 972 & 1,054 & 1,087 \\
\hline & Standard deviation & 216,180 & 230,652 & 253,658 \\
\hline \multirow[t]{3}{*}{ Amadeus } & Mean & 11,754 & 12,606 & 13,115 \\
\hline & Median & 1,176 & 1,167 & 1,222 \\
\hline & Standard deviation & 243,303 & 290,896 & 383,280 \\
\hline \multirow[t]{2}{*}{ Comparison } & Correlation & 0.987 & 0.953 & 0.918 \\
\hline & $\mathrm{P}$-value of two-tailed t-test & 0.000 & 0.024 & 0.045 \\
\hline Liabilities & Number of observations & 32,099 & 31,998 & 21,182 \\
\hline \multirow[t]{3}{*}{ ASSERT } & Mean & 6,945 & 7,620 & 6,582 \\
\hline & Median & 602 & 687 & 711 \\
\hline & Standard deviation & 125,724 & 147,338 & 131,461 \\
\hline \multirow[t]{3}{*}{ AMADEUS } & Mean & 6,864 & 7,312 & 7,869 \\
\hline & Median & 640 & 617 & 615 \\
\hline & Standard deviation & 125,842 & 167,072 & 247,847 \\
\hline \multirow[t]{2}{*}{ Comparison } & Correlation & 0.841 & 0.684 & 0.855 \\
\hline & $\mathrm{P}$-value of two-tailed t-test & 0.837 & 0.662 & 0.216 \\
\hline Depreciation & Number of observations & 31,886 & 31,742 & 20,933 \\
\hline \multirow[t]{3}{*}{ ASSERT } & Mean & 281 & 333 & 304 \\
\hline & Median & 28 & 32 & 42 \\
\hline & Standard deviation & 3,984 & 4,686 & 3,835 \\
\hline \multirow[t]{3}{*}{ Amadeus } & Mean & 262 & 281 & 243 \\
\hline & Median & 30 & 30 & 30 \\
\hline & Standard deviation & 2,892 & 3,078 & 2,701 \\
\hline \multirow[t]{2}{*}{ Comparison } & Correlation & 0.914 & 0.812 & 0.894 \\
\hline & $\mathrm{P}$-value of two-tailed t-test & 0.059 & 0.001 & 0.000 \\
\hline Operating profit/loss & Number of observations & 32,090 & 31,986 & 21,174 \\
\hline \multirow[t]{3}{*}{ ASSERT } & Mean & 594 & 301 & 575 \\
\hline & Median & 86 & 80 & 86 \\
\hline & Standard deviation & 9,697 & 25,392 & 8,732 \\
\hline \multirow{3}{*}{ Amadeus } & Mean & 802 & 553 & 748 \\
\hline & Median & 102 & 80 & 108 \\
\hline & Standard deviation & 18,453 & 20,346 & 18,209 \\
\hline \multirow[t]{2}{*}{ Comparison } & Correlation & 0.586 & -0.395 & 0.767 \\
\hline & $\mathrm{P}$-value of two-tailed t-test & 0.013 & 0.240 & 0.049 \\
\hline
\end{tabular}


Table C.17: Forecasting quality of ASSERT - United Kingdom

\begin{tabular}{|c|c|c|c|c|}
\hline Year & & 2008 & 2009 & 2010 \\
\hline Total assets & Number of observations & 8,206 & 8,046 & 3,957 \\
\hline \multirow[t]{3}{*}{ ASSERT } & Mean & 68,877 & 77,753 & 63,112 \\
\hline & Median & 5,313 & 5,830 & 5,568 \\
\hline & Standard deviation & 598,885 & 664,769 & 347,711 \\
\hline \multirow{3}{*}{ Amadeus } & Mean & 75,565 & 77,415 & 70,043 \\
\hline & Median & 6,380 & 6,419 & 6,208 \\
\hline & Standard deviation & 563,319 & 540,419 & 467,344 \\
\hline \multirow[t]{2}{*}{ Comparison } & Correlation & 0.855 & 0.830 & 0.896 \\
\hline & $\mathrm{P}$-value of two-tailed t-test & 0.055 & 0.935 & 0.047 \\
\hline Liabilities & Number of observations & 8,206 & 8,046 & 3,957 \\
\hline \multirow[t]{3}{*}{ ASSERT } & Mean & 49,108 & 58,095 & 47,525 \\
\hline & Median & 3,145 & 3,796 & 3,662 \\
\hline & Standard deviation & 501,649 & 573,274 & 285,924 \\
\hline \multirow{3}{*}{ Amadeus } & Mean & 51,103 & 51,231 & 45,815 \\
\hline & Median & 3,380 & 3,253 & 3,188 \\
\hline & Standard deviation & 406,986 & 386,232 & 275,580 \\
\hline \multirow{2}{*}{ Comparison } & Correlation & 0.743 & 0.772 & 0.929 \\
\hline & $\mathrm{P}$-value of two-tailed t-test & 0.592 & 0.095 & 0.313 \\
\hline Depreciation & Number of observations & 8,145 & 7,945 & 3,877 \\
\hline \multirow{3}{*}{ ASSERT } & Mean & 2,111 & 2,485 & 1,941 \\
\hline & Median & 117 & 134 & 154 \\
\hline & Standard deviation & 22,105 & 25,287 & 10,793 \\
\hline \multirow[t]{3}{*}{ Amadeus } & Mean & 2,196 & 2,386 & 1,707 \\
\hline & Median & 131 & 133 & 121 \\
\hline & Standard deviation & 21,885 & 22,152 & 9,721 \\
\hline \multirow[t]{2}{*}{ Comparison } & Correlation & 0.968 & 0.958 & 0.915 \\
\hline & $\mathrm{P}$-value of two-tailed t-test & 0.170 & 0.246 & 0.001 \\
\hline Operating profit/loss & Number of observations & 8,181 & 8,020 & 3,954 \\
\hline \multirow[t]{3}{*}{ ASSERT } & Mean & 4,213 & 4,146 & 5,306 \\
\hline & Median & 376 & 285 & 352 \\
\hline & Standard deviation & 42,596 & 86,602 & 44,439 \\
\hline \multirow[t]{3}{*}{ Amadeus } & Mean & 4,245 & 4,362 & 4,570 \\
\hline & Median & 409 & 356 & 440 \\
\hline & Standard deviation & 43,650 & 40,666 & 23,495 \\
\hline \multirow[t]{2}{*}{ Comparison } & Correlation & 0.481 & 0.126 & 0.418 \\
\hline & $\mathrm{P}$-value of two-tailed t-test & 0.947 & 0.831 & 0.255 \\
\hline
\end{tabular}




\section{Aufkommenswirkungen einer Abschaffung}

des Ergebnisabführungsvertrags bei der ertragsteuerlichen Organschaft

Zusammen mit Andreas Oestreicher, Reinald Koch und Stefan Hohls

Erschienen in: IFSt-Schrift Nr. 482, Berlin 2012, ISBN: 978-3-89737-026-5

Abrufbar unter:

http://www.ifst.de/flip_book/fr70b62bc8f42a0b66751fe636fc6eb0/ 


\section{1 „Modernisierung“ der Gruppenbesteuerung}

\subsection{Reformbedarf}

Kapitalgesellschaften sind selbständig körperschaftsteuerpflichtig, wenn sie ihren Sitz oder ihre Geschäftsleitung im Inland haben ( $§ 1$ Abs. 1 KStG). Davon abweichend werden die Gewinne oder Verluste einer Kapitalgesellschaft dem Gesellschafter zugerechnet und unterliegen der Besteuerung beim Gesellschafter (Organträger), wenn die Kapitalgesellschaft (Organgesellschaft) finanziell in den Gewerbebetrieb des Organträgers eingegliedert ist und sich vertraglich verpflichtet, ihren ganzen Gewinn an den Organträger abzuführen (§ 14 Abs. 1 KStG). Als Organgesellschaften kommen nur Kapitalgesellschaften mit Sitz oder Geschäftsleitung im Inland in Betracht, ${ }^{1}$ während die Rechtsform des Organträgers grundsätzlich unbedeutend ist. Der Organträger muss lediglich im Inland ein gewerbliches Unternehmen führen.

Danach beschränkt sich die Zusammenrechnung der Ergebnisse verbundener Unternehmen auf deren Inlandsergebnis. Das deutsche Organschaftsrecht öffnet sich nur insoweit über die Grenzen, als die organschaftlichen Voraussetzungen zu doppelt ansässigen Unternehmen oder der inländischen Zweigniederlassung eines ausländischen Unternehmens gegeben sind. ${ }^{2}$ Eine grenzüberschreitende Verrechnung in- und ausländischer Ergebnisse kommt zurzeit nicht in Betracht. ${ }^{3}$

Neben dieser Beschränkung auf das Inland bieten vor allem die Voraussetzung des Ergebnisabführungsvertrags und die Komplexität der rechtlichen Regelungen Anlass zur Kritik. ${ }^{4}$ Gegen die Voraussetzung einer Ergebnisabführung sprechen vor allem die Gefahr betriebswirtschaft-

\footnotetext{
${ }^{1}$ Hierzu BMF, Schreiben vom 28.03.2011, BStBl 2011 I, 300, in Reaktion auf das Vertragsverletzungsverfahren der Europäischen Kommission Nr. 2008/4909; danach ist es mit der Niederlassungsfreiheit nicht vereinbar, wenn es EU/EWR Unternehmen mit Sitz im Ausland und Geschäftsleitung im Inland versagt wird, Organgesellschaft zu sein.

${ }^{2}$ Nach BFH, Beschluss vom 09.02.2011 I R 54, 55/10, verstößt die Inlandsbeschränkung der (bis 2001) geltenden Regelung zur gewerbesteuerlichen Organschaft gegen das DBA Diskriminierungsverbot; ausländische Unternehmen können danach ohne weiteren inländischen Anknüpfungspunkt Organträger einer inländischen Organschaft sein. Nicht Gegenstand des Beschlusses war zwar die mögliche Pflicht zur Berücksichtigung ausländischer Gruppenträger bei Abschluss eines Ergebnisabführungsvertrags (EAV) mit dem ausländischen Unternehmen im Rahmen einer gewerbesteuerlichen oder körperschaftsteuerlichen Organschaft, sie könnte aber zu bejahen sein, wenn an der Notwendigkeit eines EAV nicht länger festgehalten wird; siehe aber die Nichtanwendung der Urteilsgrundsätze I R 54, 55/10, durch BMF, Schreiben vom 27.12.2011 IV C 2 - S 2770/11/10002.

${ }^{3}$ Ausnahmen mögen für „finale“ Verluste bestehen, siehe EuGH, Urteile vom 13.12.2005 - C 446/03 (Marks \& Spencer), vom 18.07.2007 - C 231/05 (Oy AA), vom 15.05.2008 - C 414/06 (Lidl Belgium), vom 25.02.2010 - C 337/08 (X Holding BV); siehe ferner BFH, Urteile vom 09.06.2010 I R 107/09 und vom 09.11.2010 I R 16/10. Die Bedeutung des EAV für den Abzug „finaler“ Verluste ist bisher nicht abschließend geklärt. Endgültige Verluste in Form von Liquidationsverlusten ausländischer Tochtergesellschaften können regelmäßig nicht Gegenstand einer Gewinnabführung sein. Anderes würde gelten, wenn die Voraussetzung des EAV unionsrechtlich zu beanstanden wäre; zu Zweifeln am Verstoß gegen das Unionsrecht siehe BFH, Urteil vom 13.10.2010 I R 79/09.

${ }^{4}$ Siehe IFSt-Arbeitsgruppe, IFSt Schrift Nr. 471, Berlin, 2011, 22 ff., dazu auch Müller-Gatermann, in Oestreicher (Hrsg), Konzernbesteuerung, Herne/Berlin 2005, 232.
} 
licher Fehlanreize, gesellschaftsrechtliche und steuerrechtliche Hürden ${ }^{5}$ sowie die Orientierung an handelsbilanziell ermittelten Ergebnissen, die vom steuerlichen Einkommen zunehmend abweichen. Darüber hinaus ist die Voraussetzung eines EAV auch unionsrechtlich nicht unproblematisch. Daher soll nach dem Koalitionsvertrag von CDU/CSU und FDP „die Einführung eines modernen Gruppenbesteuerungssystems anstelle der bisherigen Organschaft" geprüft werden. Gleichzeitig wird aber eingeschränkt, dass eine Reform der Gruppenbesteuerung nach Möglichkeit die Wahrung von Aufkommensneutralität im Blick haben sollte.

Im Auftrag des Bundesministeriums der Finanzen (BMF) befasste sich die Facharbeitsgruppe "Verlustverrechnung und Gruppenbesteuerung“ auch mit einer Prüfung von drei Alternativvorschlägen zur Reform der Gruppenbesteuerung („IFSt-Modell“, „EinkommenszurechnungsModell“ und „Gruppenbeitrags-Modell“). Sie kam nach einer ersten Bewertung zu dem Ergebnis, dass „[d]er Ersatz der Organschaft durch eines der drei Modelle zur Gruppenbesteuerung [...] ohne nennenswerte Belastungen für die Haushalte von Bund, Ländern und Kommunen nicht möglich [ist].“ Dies gelte in besonderem Maße für das IFSt-Modell mit den vorgelegten Parametern, das zu jährlichen Steuermindereinnahmen im mittleren bis oberen einstelligen Milliarden-Euro-Bereich führen würde. Im Hinblick auf die Vorgabe einer Aufkommensneutralität wurde vorgeschlagen, die Regelungen zur Organschaft gegebenenfalls mit Modifikationen beizubehalten. Für den Fall jedoch, dass „die geforderte Aufkommensneutralität im Rahmen einer Gesamtabwägung in den Hintergrund treten“ sollte, empfahl die Arbeitsgruppe „eine Umsetzung des Gruppenbeitrags-Modells“, da dieses Modell „im Vergleich zu den anderen beiden Modellen zu den geringsten Steuermindereinnahmen [führt], die sich im unteren einstelligen Milliarden-Euro-Bereich bewegen werden“ und administrativ weniger aufwändig sei. Im Bericht der Facharbeitsgruppe werden aber weder die Schätzgrundlagen noch das Berechnungsmodell dargestellt. Um vor dem Hintergrund der zum Teil entlastenden Elemente des IFSt-Modells zu prüfen, ob, und wenn ja inwieweit die Aufkommensschätzungen des BMF belastbare Ergebnisse darstellen, wurde das Institut für deutsche und internationale Besteuerung, Georg-AugustUniversität Göttingen, gebeten, den Modellvorschlag des Instituts Finanzen und Steuern (IFSt) mit Hilfe eines für entsprechende Zwecke entwickelten Mikrosimulationsmodells („ASSERT“) auf seine Aufkommenswirkungen hin zu untersuchen.

\footnotetext{
${ }^{5}$ Siehe hierzu etwa Orth, in Oestreicher (Hrsg), Konzernbesteuerung, Herne/Berlin 2005, 129.
} 


\subsection{Berechnung von Aufkommenswirkungen}

Im Bereich der Einkommensteuer und der Unternehmensteuern wird das Steueraufkommen in Deutschland mit Hilfe indirekter Prognoseverfahren geschätzt. Diese stellen für die Prognose der Bemessungsgrundlage den Bezug zu anderen Größen her und nutzen Voraussagen über deren Entwicklung für die Prognose. ${ }^{6}$ Für die Fortschreibung werden in aller Regel makroökonomische Variablen herangezogen. Wichtige Parameter sind das Bruttoinlandsprodukt und das Preisniveau sowie Teile der volkswirtschaftlichen Gesamtrechnung. Die Schätzung des Aufkommens beruht auf dem erwarteten Zusammenhang zwischen der Bemessungsgrundlage und dem Steueraufkommen. Dieser Zusammenhang wird mit Hilfe einer „Elastizitätenmethode“ und ökonometrischen Modellen ermittelt. Auf dieser Grundlage kann die Steuerschätzung auch komplexe Sachverhalte des Steuersystems abbilden und steuerrechtliche Änderungen berücksichtigen. Problematisch ist aber die Verwendung zahlreicher Schätzwerte, die zu Schätzungenauigkeiten führen können.

Während gesamtwirtschaftliche Prognosen auf stark aggregierten Daten beruhen, wird bei Mikrosimulationen unmittelbar auf die Ebene des Steuerzahlers oder der Unternehmen abgestellt. Mikroökonomische Modelltypen erfassen explizit die Strukturmerkmale der Steuerpflichtigen und ermöglichen differenzierte Aussagen über die Wirkungen von Steuerreformen. Mit Hilfe von Mikrosimulationsmodellen wird die Entwicklung von Unternehmen modelliert und durch Simulation auf die Mikroeinheiten einer Stichprobe übertragen. Dabei können steuerrechtliche Änderungen detailliert erfasst werden und es lässt sich auch berücksichtigen, dass eine Änderung des Steuerrechts auf Ebene der Unternehmen mit Verhaltensreaktionen verbunden sein kann. Problematisch ist allerdings, dass die erforderlichen Daten in aller Regel nicht tagesaktuell zur Verfügung stehen. Ihre Beschaffung ist im Bereich der Besteuerung mit besonderen Schwierigkeiten verbunden, da steuerliche Sekundärdaten strengen Beschränkungen unterliegen. Einen Ausweg bieten publizierte Jahresabschlussdaten, die, soweit das aus der externen Perspektive möglich ist, an die steuerliche Rechtslage angepasst werden müssen.

In diesem Sinne ist das im Rahmen dieser Studie zur Anwendung gebrachte Mikrosimulationsmodell ASSERT (Assessing the Effects of Reforms in Taxation) in der Lage, individuelle Unternehmensentwicklungen auf der Basis historischer Jahresabschlussdaten progressiv fortzuschreiben, unter Beachtung wesentlicher Unterschiede zwischen den handelsrechtlichen Ergebnissen und den zu versteuernden Einkommen periodenspezifische Steuerzahlungen abzuleiten

\footnotetext{
${ }^{6}$ Siehe Büttner und Kauder, Monatsbericht des BMF, Juni 2008, 55-65, Büttner und Kauder, Fiscal Studies (31) 2010, 313-340.
} 
und durch Aggregation dieser Steuerzahlungen die Aufkommenswirkungen steuerlicher Reformmaßnahmen abzuschätzen. Dieses Modell wird in Gliederungspunkt D.6 näher beschrieben und ist separat dokumentiert. ${ }^{7}$ Die in ASSERT verarbeitete Datenbasis endet zur Zeit mit dem Jahr 2007, sein Prognosezeitraum beträgt grundsätzlich vier Jahre (derzeit 2008 bis 2011). Ziel des Modells ist die Quantifizierung relativer Aufkommensänderungen, die sich durch die Umsetzung von Steuerreformen ergäben. Hierzu werden die Steuerfolgen verglichen, die sich aus der Anwendung des für den Prognosezeitraum (2008 bis 2011) geltenden Steuerrechts und des Steuerrechts ergeben, wie es sich nach einer möglichen Reform darstellt. Die Prognose absoluter Aufkommenszahlen steht dagegen nicht im Vordergrund.

Im Interesse der politischen Kommunikation wurden die ermittelten „Aufkommenswirkungen“ jedoch für Zwecke des vorliegenden Berichts in absolute Zahlen „,̈̈bersetzt“ (Gliederungspunkte D.3.3, D.3.4). Sie wurden durch Multiplikation der relativen Aufkommensänderungen mit dem entstehungsmäßigen Körperschaftsteueraufkommen und dem Gewerbesteueraufkommen der Jahre 2008 bis 2011 bestimmt und geben damit die Summe der erwarteten Aufkommensänderungen für einen Zeitraum von vier Jahren wieder. Wollte man einen Näherungswert für die Jahreswirkung ermitteln, wären die berichteten Zahlen durch vier zu teilen, wenn auch nicht zu erwarten ist, dass sich die Jahreswirkungen gleichmäßig verteilen (siehe dazu Tabelle D.5). Bei den „Verteilungswirkungen“ (Gliederungspunkt D.3.6) steht dagegen der relative Vergleich im Vordergrund. Hier werden die Gewichte (in Prozent) aufgezeigt, in dem die Konzernunternehmen in Abhängigkeit von Größe, Branchenzugehörigkeit und Sitzstaat der Muttergesellschaft von einer Reform der Gruppenbesteuerung betroffen wären. Diese Quervergleiche sind für die Höhe des Steueraufkommens nicht unmittelbar relevant, so dass an dieser Stelle auf eine „Übersetzung“ in absolute Zahlen verzichtet werden kann.

\subsection{Struktur dieses Berichts}

Der vorliegende Bericht fasst die Schätzung der Aufkommens- und Verteilungswirkungen zusammen, die mit der Einführung „moderner“ Elemente einer Gruppenbesteuerung verbunden wären. Gegenstand von Kapitel D.2 ist zunächst eine Beschreibung der Eckdaten des IFSt-Modells. Eingegangen wird auf die zentralen Voraussetzungen (unterschiedliche Mindestbeteiligungsquoten, Verzicht auf den Abschluss eines Ergebnisabführungsvertrags) und inhaltlichen Ausgestaltungen des Reformvorschlags (Art und Umfang der Verlustzurechnung zum Gruppenträger). In

\footnotetext{
${ }^{7}$ Oestreicher, Koch, Vorndamme und Hohls, ASSERT, Assessing the Effects of Reforms in Taxation, A Microsimulation approach, Göttingen 2011. Die Dokumentation wird gegenwärtig überarbeitet, kann aber bei den Autoren angefordert werden und wird nach ihrer Überarbeitung gerne zur Verfügung gestellt.
} 
Kapitel D.3 werden die Ergebnisse der für die verschiedenen Reformszenarien durchgeführten Simulationsrechnungen vorgestellt und diskutiert. Wenngleich sich der EuGH bisher noch nicht mit der de lege lata bestehenden Voraussetzung des (doppelten) Inlandsbezugs und der daraus folgenden Binnenorientierung der Organschaft auseinandergesetzt und auch in der Rechtssache C 337/08 („X Holding“) den Aspekt einer Wahrung der Besteuerungsbefugnisse betont hat, ist es auf der Grundlage des EuGH-Urteils in der Rechtssache C 446/03 („Marks \& Spencer“) verbreitete Meinung, dass „endgültige“ („finale“) Verluste ausländischer Tochtergesellschaften bei einer inländischen Muttergesellschaft zu berücksichtigen sind. Daher wird zudem - außerhalb der mit Hilfe von ASSERT angestellten Berechnungen - eine Hochrechnung jener finalen Verluste ausländischer Tochtergesellschaften vorgenommen, die anlässlich einer Liquidation verlustführender Tochtergesellschaften von deutschen Muttergesellschaften zu tragen wären. Diese Überlegungen sind Gegenstand von Kapitel D.4. Sie werden ergänzt um eine zusammenfassende Würdigung der Berechnungsergebnisse in Kapitel D.5. Diese Würdigung dient der politischen Kommunikation und zeichnet sich durch Wertungen aus, auf die zugunsten einer objektiven Betrachtung in den Kapiteln D.1 bis D.4 bewusst verzichtet wurde. In Kapitel D.6 wird schließlich das Mikrosimulationsmodell ASSERT in seinen wesentlichen Grundzügen vorgestellt. Im Einzelnen wird auf die Datenbasis und Fortschreibungstechnik, die Ermittlung von Steuerzahlungen und Steueraufkommen sowie die Güte des Simulationsansatzes eingegangen. Dabei basiert der vorliegende Bericht auf den Jahresabschlussdaten deutscher Kapitalgesellschaften bis einschließlich 2007, womit die Abschaffung des EAV (Beginn der Untersuchungsperiode) technisch auf den Beginn des Jahres 2008 verlagert wird. Die Fortschreibung ist bis zum Jahr 2011 und (mit Einschränkungen) bis zum Jahr 2013 möglich, so dass die Aufkommenswirkungen über eine Vierund Sechsjahresperiode dargestellt werden. Diese Vorverlagerung des Anwendungszeitraumes bewirkt, dass sich die Aufkommensschätzungen auf die gesamtwirtschaftlichen Entwicklungen der Jahre 2008 bis 2011 (2013) beziehen, ist aber aufgrund der „historischen“ Datenbasis nicht zu vermeiden. Sie führt zu Schätzungsungenauigkeiten, wenn und soweit die gesamtwirtschaftliche Entwicklung der Reformperioden (2013 ff.) von den Perioden abweichen, die den Berechnungen zugrunde liegen (2008 bis 2013). Da für Personengesellschaften die erforderlichen Daten nicht verfügbar sind, beschränken sich die Berechnungen auf Unternehmen, die in der Rechtsform einer Kapitalgesellschaft auftreten. 


\section{Eckdaten des IFSt-Modells}

Der Reformvorschlag der IFSt-Arbeitsgruppe besteht im Einzelnen aus insgesamt zwanzig Punkten, ${ }^{8}$ die für Zwecke einer Schätzung von Aufkommenswirkungen nur zum Teil relevant sind. Klammert man die Elemente aus, die auf ein „Beibehalten“ des Status Quo abstellen (zum Beispiel die Thesen 3 bis 5, 7.2, 8 und 11), formale Fragen adressieren (zum Beispiel die Nummern 9, 10, 19 und 20) oder den Verzicht auf weitergehende Forderungen zum Gegenstand haben (zum Beispiel die Thesen 14 und 18.1), zeigt sich, dass sich die Schätzung der Aufkommenswirkungen auf fünf zentrale Elemente stützen kann. Bei diesen Punkten handelt es sich um die Nummern

1: Abschaffung des Ergebnisabführungsvertrags zum 1. Januar 2012,

7: Anhebung der Mindestbeteiligungsquote des Gruppenträgers an der Gruppengesellschaft auf eine qualifizierte Mehrheit in Höhe von 75\% (am Nennkapital und an den Stimmen),

6: Mögliche Begrenzung der Verlustzurechnung auf den Betrag des Gruppenträgerinvestments (nicht präferiert/empfohlen),

12: Verrechnung von vor Begründung der Gruppe entstandener Verluste der Tochtergesellschaft mit in der Gruppenzeit erwirtschafteten Gewinnen der Tochtergesellschaft und

18.2: Berücksichtigung „echter“ finaler Verluste von in EU-/EWR-ansässigen Auslandsgesellschaften, sofern diese Gesellschaften die Voraussetzungen der Gruppenbesteuerung erfüllen.

Wesentliches Element des IFSt-Modells ist die Abschaffung des Gewinnabführungsvertrages (These 1). Dies wird daher im Folgenden auch allen Aufkommensberechnungen für das IFStModell einheitlich zugrunde gelegt.

Um dem Gedanken der wirtschaftlichen Einheit des Konzerns stärker Rechnung zu tragen, soll die Mindestbeteiligungsquote auf $75 \%$ am Nennkapital und an den Stimmen heraufgesetzt werden, wobei in Fortführung des geltenden Rechts weiterhin auch mittelbare Beteiligungen anerkannt würden (These 7). Diese Voraussetzung muss im Rahmen der folgenden Berechnungen insoweit eingeschränkt werden, als es auf der Basis von Jahresabschlussdaten nicht möglich ist, die Beteiligung einer Muttergesellschaft an den Stimmen der Tochtergesellschaft zu identifizieren, so dass allein das Nennkapital zugrunde gelegt wird. Daneben soll nach den Unterschieden gefragt werden, wenn anstelle einer Mindestbeteiligungsquote in Höhe von $75 \%$ alternativ $95 \%$ und $100 \%$ zugrunde gelegt werden.

\footnotetext{
${ }^{8}$ Vgl. IFSt, Reformvorschlag, 2011, 40-42, abgedruckt auch hier im Anhang.
} 
Ausgehend von der wirtschaftlichen Einheit des Konzerns soll es, vor allem wenn zugleich die Anforderungen an die Beteiligungsquote angehoben werden, bei einer unbegrenzten sofortigen Zurechnung des Verlusts der Gruppengesellschaft bleiben. Wird es hingegen für erforderlich gehalten, dass dem Gedanken der Verlusttragung stärker Rechnung getragen wird, kann dies durch eine Begrenzung auf den Betrag des Gruppenträgerinvestments erreicht werden, wenngleich die IFSt-Arbeitsgruppe dies nicht empfiehlt (These 6). Diese Begrenzung wird im Rahmen der nachfolgenden Berechnungen an der Höhe des (handelsrechtlichen) Beteiligungsbuchwerts festgemacht.

Verluste, die einer Organgesellschaft vor der Begründung einer Organschaft entstanden sind, werden de lege lata für die Dauer der Organschaft „eingefroren“. Im Unterschied dazu sollte nach dem IFSt-Modell die Verrechnung von vor Begründung der Gruppe entstandenen Verlusten der Tochtergesellschaft mit in der Gruppenzeit erwirtschafteten Gewinnen der Tochtergesellschaft möglichst zugelassen werden (These 12).

In Bezug auf grenzüberschreitende Sachverhalte greift der Reformvorschlag auch das bereits angesprochene Gebot zur steuerlichen Berücksichtigung „finaler“ Verluste ausländischer Gruppengesellschaften auf (These 18.2). Während das IFSt derartige Verluste jedenfalls zu berücksichtigen empfiehlt, nimmt es in Anbetracht der unwägbaren Haushaltswirkungen sowie praktischer Umsetzungsschwierigkeiten von den Plänen einer dem Nachversteuerungsvorbehalt unterliegenden uneingeschränkten Zurechnung von Verlusten ausländischer Gruppengesellschaften Abstand (These 18.1). Anders als die erstgenannten vier Reformaspekte, die explizit Eingang in die mittels ASSERT durchgeführten Simulationsberechnungen finden, basiert die Abschätzung der mit einer Verrechnung „finaler" Auslandsverluste einhergehenden Aufkommenswirkungen auf einer vereinfachten Hochrechnung unter Bezug auf (1) die Direktinvestitionsstatistik der Deutschen Bundesbank, Daten aus Amadeus und Statistiken von Eurostat sowie (2) Daten aus Amadeus und der Körperschaftsteuerstatistik 2007.

\section{Aufkommenseffekte einer Reform der Gruppenbesteuerung nach dem IFSt-Modell}

\subsection{Wirkungsdauer und Wirkungsrichtung möglicher Aufkommenseffekte}

Bevor in den nachfolgenden Abschnitten auf die Ergebnisse der Modellberechnungen im Einzelnen eingegangen wird, sollen zunächst die zu erwartenden Wirkungen auf das Steuerauf- 
kommen diskutiert werden, die mit einer Umsetzung der mit dem IFSt-Modell verbundenen Änderungsvorschläge einhergingen. In Bezug auf ihre Wirkungsdauer können diese Änderungsvorschläge danach unterschieden werden, ob sie das Steueraufkommen permanent ändern oder vorübergehender Art sind, das heißt im Vergleich zum gegenwärtigen Recht definitive oder sich im Zeitablauf wieder umkehrende Aufkommenseffekte zur Folge haben. Was ihre Wirkungsrichtung betrifft, sind Elemente, die eine Minderung des Steueraufkommens zur Folge haben, und Vorschläge, die eine Erhöhung des Steueraufkommens bewirken, zu unterscheiden. Inhaltlich betroffen sind im Rahmen der Körperschaftsteuer ${ }^{9}$

- eine zu entrichtende Kapitalertragsteuer und nicht als Betriebsausgaben abziehbare Ausgaben in Bezug auf konzerninterne Gewinnausschüttungen,

- negative Einkünfte (Mindestbesteuerung),

- Verlustvorträge und

- der Betriebsausgabenabzug für Zinsaufwendungen.

Geht man davon aus, dass die Abschaffung des Ergebnisabführungsvertrags (These 1) selbst für den Fall einer Anhebung der Mindestbeteiligungsquote des Gruppenträgers an der Gruppengesellschaft auf eine qualifizierte Mehrheit in Höhe von 75\% (These 7) zu einer Ausweitung der Anzahl Kapitalgesellschaften führt, deren Einkommen nach dem Konzept einer Gruppenbesteuerung in die Veranlagung des „Organträgers“ einbezogen wird, ${ }^{10}$ bewirken die Vorschläge der IFSt-Arbeitsgruppe, dass auch die Anzahl der Fälle steigt, in denen Gewinne „zugerechnet“ werden (These 13), während das Volumen der Gewinne, die der Ausschüttungsbesteuerung unterliegen, mit der Anzahl Kapitalgesellschaften, die außerhalb einer Organschaft stehen, zurückgeht. Damit verbunden reduzieren sich die auf Ausschüttungen zu entrichtende Kapitalertragsteuer ( $\S 43$ Abs. 1 S. 1, 3; 36 Abs. 2 Nr. 2 EStG) und auch die Ausgaben, die im Hinblick auf diese Gewinnausschüttungen nicht als Betriebsausgaben abgezogen werden dürfen (§ 8b Abs. 5 KStG). Letztere Minderung des Steueraufkommens führt zu definitiven Aufkommensrückgängen. Im Bezug auf die Kapitalertragsteuer ist die Wirkung temporär und beschränkt sich auf das zeitliche Auseinanderfallen von Steuerabführung und -erstattung.

\footnotetext{
${ }^{9}$ Vergleichbares gilt auch für die Gewerbesteuer. Die Berücksichtigung weitergehender Effekte bei der Gewerbesteuer, die sich zum Beispiel aus der Hinzurechnung für konzerninterne Leistungsbeziehungen oder der Gewerbesteuerzerlegung ergeben, ist auf Basis der verwendeten Daten nicht möglich.

${ }^{10}$ Siehe hierzu Gliederungspunkt D.3.3.1, Tabelle D.1; dazu auch Oestreicher und Koch, RevManagSci (2010) 4, 135, Abbildung 2. Diese Abbildung zeigt, dass bei circa 80 von 100 Gruppenträgern, die zu mehr als $50 \%$ an nachgeordneten Gesellschaften beteiligt sind, die Beteiligungsquoten größer $80 \%$ sind. Diese hohe Konzentration ist auch international nicht unüblich, siehe Poppe, Auswirkungen der Einführung einer konsolidierten Körperschaftsteuer-Bemessungsgrundlage in der Europäischen Union, Frankfurt am Main 2008, 148, Tabelle 33.
} 
In Bezug auf negative Einkünfte sieht das Modell der IFSt-Arbeitsgruppe vor, dass es „bei einer unbegrenzten sofortigen Zurechnung des Verlusts der Gruppengesellschaft zum Gruppenträger bleiben“ kann (These 6). Daneben bewirkt die „bewährte Technik der steuerlichen Ergebniszurechnung zur Obergesellschaft" (These 3), dass Verluste des Gruppenträgers mit Gewinnen einer Gruppengesellschaft verrechnet werden können. Wird unterstellt, dass sich die Vorzeichen der steuerlichen Ergebnisse verbundener Unternehmen häufig unterscheiden, ${ }^{11}$ wird das Potenzial unmittelbar verrechenbarer Verluste grundsätzlich zunehmen, wenn die Abschaffung des Ergebnisabführungsvertrags zu einer Ausweitung der Anzahl Kapitalgesellschaften führt, deren Einkommen nach dem Konzept einer Gruppenbesteuerung in die Veranlagung des „Organträgers" einbezogen wird. Eine damit verbundene Minderung des Aufkommens ist aber temporärer Natur. Zwar ist der Verlustabzug im Bereich der Körperschaftsteuer und Gewerbesteuer der Höhe nach begrenzt ( $\S \S 8$ KStG, 10d EStG, 10a GewStG), so dass im Hinblick auf die Mindestbesteuerung generelle Aussagen kaum möglich sind (bei einer Veranlagung der Einkünfte auf Ebene des Gruppenträgers kann der Sockelbetrag in Höhe von einer Million € nur einmal genutzt werden, was für den Steuerpflichtigen nachteilig sein und für den Fiskus einen positiven Aufkommenseffekt haben kann). In zeitlicher Hinsicht existieren aber gegenwärtig keine Schranken, so dass sich die Aufkommensminderung über die Zeit insoweit ausgleicht, als erlittene Verluste außerhalb einer Gruppenbesteuerung mit künftigen Gewinnen verrechnet werden können. Lediglich in den Fällen, in denen einzelne Konzerngesellschaften dauerhaft Verluste erzielen, wären die Aufkommensrückgänge, die sich aus einer Lockerung der Voraussetzungen, die an eine Verlustverrechnung zwischen Gruppengesellschaften gestellt werden, definitiver Natur.

Werden vor Begründung der Gruppe entstandene Verluste der Tochtergesellschaft nicht länger „eingefroren“ (§ 15 S. 1 Nr. 1 KStG, These 12), wird bei Organgesellschaften, die qua Gewinnabführungsvertrag in eine Organschaft eingebunden sind, die Verrechnung von „Vorgruppenverlusten" mit künftigen Gewinnen möglich (während sich für neu hinzutretende Gruppengesellschaften, deren Ergebnisse unter den Voraussetzungen des IFSt-Modells konsolidiert werden, keine Änderung ergäbe). Die hiermit verbundene Verbesserung einer Verrechnung von „Vorgruppenverlusten“ würde das Steueraufkommen nur temporär reduzieren. Diese Aufkommensminderung gliche sich aus, sobald die betroffenen Gesellschaften aus der Gruppe ausscheiden und ihre vor Begründung der Gruppe entstandenen Verluste (unter den Beschränkungen der Mindestbesteuerung) selbständig mit künftigen Gewinnen verrechnen könnten. In Abhängigkeit

\footnotetext{
${ }^{11}$ Ein Blick auf die Verteilung von Gewinnen und Verlusten in Gruppen verbundener Unternehmen zeigt, dass sich diese Vorzeichen in mehr als 40\% aller Fälle unterscheiden, siehe Oestreicher und Koch, RevManagSci (2010) 4, 134, Tabelle 5 .
} 
von der Dauer der Gruppenzugehörigkeit, der Höhe der Vorgruppenverluste und der Struktur der zukünftigen Gewinne, kann sich dieser Ausgleich jedoch über Jahre verteilen.

Beibehalten werden sollen nach dem Vorschlag der IFSt-Arbeitsgruppe auch die Besonderheiten der Bruttomethode, die Betriebsfiktion bei Anwendung der Zinsschranke und die Folgen der gebrochenen Einheitstheorie (These 11). Insoweit würden Organträger und Organgesellschaften in Bezug auf den Betriebsausgabenabzug für Zinsaufwendungen weiterhin als ein Betrieb gelten (§ 15 S. 1 Nr. 3 KStG). Mit dieser Fiktion können für den Steuerpflichtigen insoweit Vorteile verbunden sein, als alle Zinsaufwendungen und Zinserträge aufgrund von Verbindlichkeiten und Forderungen zwischen den Gesellschaften, die einem Organkreis angehören, bei der Berechnung des Zinssaldos nicht berücksichtigt werden. Auf Ebene des Organträgers werden alle Zinsaufwendungen und Zinserträge in den Zinssaldo einbezogen, die auf Rechtsbeziehungen mit Gläubigern und Schuldnern beruhen, die außerhalb des Organkreises stehen. Dieser Zinssaldo unterliegt der Abzugsbeschränkung auf Ebene des Organträgers, wenn er die einschlägige Freigrenze (§ 4h S. 1 Buchstabe a EStG) übersteigt. Hieraus können sich Aufkommensminderungen für den Fiskus ergeben, wenn sich die Möglichkeiten des Betriebsausgabenabzugs für den Steuerpflichtigen verbessern. Die Freigrenze wird allerdings für den Organkreis nur einmal gewährt, so dass sich die Organschaft auch zugunsten des Fiskus auswirken kann. Geht man davon aus, dass die Abschaffung des Ergebnisabführungsvertrags zu einer Ausweitung der Anzahl Kapitalgesellschaften führt, deren Einkommen nach dem Konzept einer Gruppenbesteuerung in die Veranlagung des „Organträgers" einbezogen wird, werden sich die mit der Betriebsfiktion verbundenen Effekte verstärken. Grundsätzlich sind aber auch diese Effekte temporärer Natur. Ihr Ausgleich in der Zeit hängt von der Entwicklung der separaten und zusammengefassten EBITDA und Zinssalden ab. Definitive Bedeutung hätte allerdings die Beendigung einer Gruppe, da sie zu einer Aufgabe des fingierten Betriebs und, damit verbunden, dem Untergang eines nicht verbrauchten EBITDA und Zinsvortrags führen würde (§ $4 \mathrm{~h}$ Abs. 5 EStG).

Da die Modellierung in ASSERT eine Beschränkung auf ausgewählte Besteuerungsparameter voraussetzt, kann im Rahmen der Analyse nicht allen Sekundärwirkungen des IFSt-Modells Rechnung getragen werden, da sie auf zum Teil komplizierten Abhängigkeiten innerhalb der steuerlichen Vorschriften beruhen. Auszublenden war hier vor allem die wechselseitige Abhängigkeit zwischen dem Betriebsausgabenabzug für Zinsaufwendungen und den erweiterten Möglichkeiten der Verlustverrechnung nach dem IFSt-Modell. Weitere Vereinfachungen sind im Rahmen der folgenden Ergebnisdarstellung dokumentiert. Gleichfalls unberücksichtigt bleiben mögliche Aufkommenswirkungen aus verunglückter Organschaft. 


\subsection{Struktur der vorliegenden Aufkommensberechnungen}

Für Zwecke der vorliegenden Untersuchung empfiehlt es sich, die Aufkommensberechnungen in mehrere Schritte zu untergliedern, wenn auch die Abschaffung des Ergebnisabführungsvertrags allen Berechnungen einheitlich zugrunde liegt. So richtet sich in einem ersten Schritt das Interesse auf die Auswirkungen, die sich unter dieser Voraussetzung aus einer Anhebung der Mindestbeteiligungsquote auf alternativ 75, 95 und 100\% ergäben. Ermittelt werden sollen (1) die Anzahl betroffener Konzerngesellschaften und (2) die entsprechenden Auswirkungen auf das Steueraufkommen.

Im Rahmen des zweiten Untersuchungsschrittes wird von einer Anhebung der Mindestbeteiligungsquote auf die Höhe von $75 \%$ ausgegangen (Basisszenario). Unter dieser Voraussetzung wird nach den Folgen für das Steueraufkommen gefragt, wenn die Verlustverrechnung (1) auf den Beteiligungsbuchwert begrenzt wird, (2) auf Verluste erstreckt wird, die einer Organgesellschaft vor der Begründung einer Organschaft entstanden sind, oder (3) berücksichtigt wird, dass nicht alle Konzernunternehmen, für die die Voraussetzungen vorlägen, tatsächlich auch einen entsprechenden Gruppenantrag stellen.

Gegenstand des dritten Untersuchungsschrittes sind die möglichen Effekte, die aus der Anwendung des IFSt-Modells über den Zeitraum von sechs Jahre erwartet werden, und die Abhängigkeit der berechneten Werte von der Höhe und Verteilung der ermittelten Körperschaftsteuerverlustvorträge. Letztere Untersuchung ist erforderlich, da im Rahmen der hier verwendeten Datenbasis die Verlustvorträge tendenziell untererfasst sind (siehe hierzu Abschnitt D.6.5.2). Daher wird analysiert, inwieweit die Ergebnisse robust sind gegenüber der Berücksichtigung zusätzlicher Verlustvorträge.

Im Rahmen des vierten Untersuchungsschrittes konzentriert sich das Interesse auf die Verteilungswirkungen bei konzernzugehörigen Unternehmen. Gegenstand dieser Betrachtungen sind mögliche (1) Größeneffekte, (2) Brancheneffekte und (3) Konzernstruktureffekte.

Über die Berechnung mit Hilfe des Mikrosimulationsmodells ASSERT in Kapitel D.3 hinaus werden schließlich in Kapitel D.4 die Aufkommenswirkungen geschätzt, die sich aus einer Verrechnung finaler Verluste ergäben, die anlässlich der Liquidation ausländischer Tochtergesellschaften auf inländische Muttergesellschaften entfallen würden. 


\subsection{Anhebung der Mindestbeteiligungsquote auf alternativ 75, 95 oder $100 \%$}

\subsubsection{Anzahl betroffener Kapitalgesellschaften in der Stichprobe}

Gegenstand dieses ersten Untersuchungsschrittes sind die Auswirkungen, die sich unter der Voraussetzung einer Abschaffung des Ergebnisabführungsvertrags aus einer Anhebung der Mindestbeteiligungsquote (MBQ) auf alternativ 75, 95 und 100\% ergäben. Zu diesem Zweck zeigt die nachfolgende Tabelle D.1 in Beantwortung der ersten Teilfrage zunächst auf, wie viele Kapitalgesellschaften der Stichprobe vor und nach Abschaffung des Ergebnisabführungsvertrags (1) als Gruppenträger fungieren (können), (2) Gruppengesellschaften sind oder (3) als wirtschaftlich selbständige Kapitalgesellschaften keiner Organschaft oder Gruppe angehören.

Tabelle D.1: Zusammensetzung Kapitalgesellschaften in der Stichprobe

\begin{tabular}{|c|c|c|c|c|c|c|}
\hline \multicolumn{2}{|c|}{ Anzahl der... } & \multirow{2}{*}{$\frac{1}{543}$} & \multirow{2}{*}{$\frac{2}{848}$} & \multirow{2}{*}{$\frac{3}{6.380}$} & \multirow{2}{*}{$\begin{array}{l}4 \\
-524\end{array}$} & \multirow{2}{*}{$\frac{5}{7.247}$} \\
\hline 离 & $\mathrm{MBQ}>50 \%$ & & & & & \\
\hline \multirow{3}{*}{ 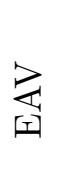 } & $\mathrm{MBQ}=75 \%$ & 520 & 801 & 6.414 & -488 & 7.247 \\
\hline & $\mathrm{MBQ}=95 \%$ & 494 & 736 & 6.464 & -447 & 7.247 \\
\hline & $\mathrm{MBQ}=100 \%$ & 479 & 698 & 6.493 & -423 & 7.247 \\
\hline \multirow{3}{*}{ 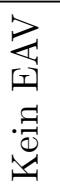 } & $\mathrm{MBQ}=75 \%$ & 1.340 & 1.920 & 5.109 & -1.122 & 7.247 \\
\hline & $\mathrm{MBQ}=95 \%$ & 1.171 & 1.608 & 5.436 & -968 & 7.247 \\
\hline & $\mathrm{MBQ}=100 \%$ & 1.119 & 1.522 & 5.522 & -916 & 7.247 \\
\hline
\end{tabular}

1: Gruppenträger, 2: Gruppengesellschaften, 3: Wirtschaftlich selbständige Kapitalgesellschaften, 4: Gesellschaften mit nicht zureichender Datenlage, 5: Summe

Für das gegenwärtige Recht (erste Zeile: „EAV, MBQ > 50\%“) ergibt sich die Zuordnung der Unternehmen zu den Kategorien „Gruppenträger“, „Gruppengesellschaft“ oder „,wirtschaftlich selbständige Kapitalgesellschaft" aus den vorliegenden Daten. Was die Reformszenarien „EAV“/,Verzicht auf EAV“ sowie alternative MBQ betrifft, geht die Tabelle von dem für den Fiskus grundsätzlich ungünstigsten Optionsverhalten der Unternehmen aus. Es wird angenommen, dass die Gruppenbesteuerung immer dann in Anspruch genommen wird, wenn die jeweiligen Voraussetzungen seitens der Unternehmen erfüllt werden. ${ }^{12}$

Festzustellen ist zunächst, dass eine Verschärfung des Beteiligungsquotenerfordernisses bei fortwährender Verpflichtung zum Abschluss eines Ergebnisabführungsvertrags zur Konsequenz hat, dass im Vergleich zum geltenden Recht der Organschaftsbesteuerung weniger Unternehmen

\footnotetext{
${ }^{12} \mathrm{Zu}$ den erwarteten Auswirkungen eines Optionsrechts für die Gruppenbesteuerung siehe Gliederungspunkt D.3.4.3.
} 
die Voraussetzungen zur Inanspruchnahme der Gruppenbesteuerung werden erfüllen können. Die relativen Zuwächse bei den „wirtschaftlich selbständigen Kapitalgesellschaften“ (Spalte „3“), belaufen sich je nach Beteiligungsschwelle auf $(6.414-6.380) / 6.380=0,5 \%(, \mathrm{MBQ}=75 \%$ “), $(6.464-6.380) / 6.380=1,3 \%(, \mathrm{MBQ}=95 \% ")$ und $(6.493-6.380) / 6.380=1,8 \%(, \mathrm{MBQ}=100 \%$ " $)$ im Vergleich zum geltenden Recht.

Eine Abschaffung der Voraussetzung des Abschlusses eines Ergebnisabführungsvertrags zwischen dem Organträger und den Organgesellschaften bewirkt nach unseren Berechnungen dagegen einen sprunghaften Anstieg der die Gruppenbesteuerung beanspruchenden Unternehmen und wirkt sich wesentlich stärker aus als eine lediglich auf die Anhebung der vorausgesetzten Mindestbeteiligungsquote gerichtete Reform. Die relative Zunahme der Organgesellschaften beträgt im Vergleich zum Szenario mit Verpflichtung zum Abschluss eines Ergebnisabführungsvertrags $(1.920-801) / 801=139,7 \%\left({ }^{M} \mathrm{MBQ}=75 \% “\right),(1.608-736) / 736=118,5 \%$ $(, \mathrm{MBQ}=95 \%$ “) und $(1.522-698) / 698=118,1 \%(, \mathrm{MBQ}=100 \% “)$.

\subsubsection{Aufkommenswirkungen}

Die zweite Teilfrage richtet sich auf die Aufkommenswirkungen, die mit einer Anhebung der Mindestbeteiligungsquote auf 75, 95 und 100\% verbunden wäre, wenn gleichzeitig die Voraussetzung eines Ergebnisabführungsvertrags abgeschafft würde.

Die Aufkommenswirkungen werden aus dem Rückgang der (Summe der) Körperschaftsteuerbemessungsgrundlagen ermittelt und zunächst als relative Veränderung dieser Bemessungsgrundlagen dargestellt. Sie geben den Gesamteffekt an, der sich für die drei Reformszenarien aus jeweils der Summe der jährlichen Einzeleffekte in Bezug auf den vierjährigen Simulationszeitraum ergibt. Bei einer Anhebung der Mindestbeteiligungsquote auf $75 \%$ wäre danach mit einem Rückgang der Körperschaftsteuerbemessungsgrundlage (und, hochgerechnet, dem Körperschaftsteueraufkommen) in Höhe von durchschnittlich (gewichteter Durchschnitt) 2,11\% der Bemessungsgrundlage/des Aufkommens zu rechnen, das sich bei einer Mindestbeteiligungsquote in Höhe von 50\% ergibt. Wie schon dargestellt (Gliederungspunkt D.1.2), werden die prozentualen Angaben im Interesse der politischen Kommunikation ferner in absolute Werte „übersetzt“. Die Grundlage dieser Umrechnung bilden die „Kasseneinnahmen“ nach den Angaben des Arbeitskreises Steuerschätzung vom Mai 2012. Für die Jahre 2008 bis 2011 (siehe auch hierzu Gliederungspunkt D.1.2) betragen diese Einnahmen 15.868, 7.173, 12.041 und 15.634 Millionen $€$.

Bezogen auf diese Kasseneinnahmen der Körperschaftsteuer ergeben sich erste Aufkommens- 
effekte aus einer Abschaffung des Gewinnabführungsvertrags. Bei einer Anhebung der Beteiligungsquote auf $75 \%$ entsprächen diese Verluste in Bezug auf die Körperschaftsteuer einem Rückgang des Aufkommens in Höhe von 563 Millionen € für das Jahr 2008 und einem Aufkommensrückgang in Höhe von 1.190 Millionen $€$ für den Zeitraum 2008 bis 2011. Dieser Rückgang reduziert sich mit steigender Beteiligungsanforderung und beliefe sich auf $-1,37 \%$, wenn man sich auf eine Beteiligungsquote von $100 \%$ bezieht. ${ }^{13}$

Würde die Reform der steuerlichen Organschaft am Ergebnisabführungsvertrag festhalten und sich allein auf die Anhebung der Beteiligungsquotengrenzen beschränken, würde sich das, unabhängig von der konkreten Höhe der vorausgesetzten Beteiligungsquote, nur unwesentlich (positiv) auf das Körperschaftsteueraufkommen auswirken. Die prognostizierten Aufkommenszuwächse im Vergleich zum geltenden Recht würden durchweg weniger als $+0,5 \%$ betragen.

Für die Prognose der Aufkommenswirkungen sind die Kasseneinnahmen allerdings nur mit Einschränkungen geeignet. Zu berücksichtigen ist, dass die Kasseneinnahmen um Investitionszulagen, die „Altkapitalerstattungen“ (aus dem Übergang vom Anrechnungs- zum Teileinkünfteverfahren) reduziert und um den (positiven) Saldo aus Nachzahlungs- und Erstattungszinsen (§ 233a AO) erhöht sind. Für die insoweit „bereinigten“ Kasseneinnahmen sind aktuelle Daten im BMF verfügbar. Sie betragen 17.991, 9.699, 14.647 und 17.951 Millionen € für die Jahre 2008 bis 2011. Auf dieser Grundlage beliefen sich die Aufkommensminderungen bei Abschaffung des Ergebnisabführungsvertrags und einer Anhebung der Mindestbeteiligungsquote auf durchschnittlich 2,28\% (,MBQ=75\%“) oder 1.373 Millionen $€$ (bezogen auf den Vierjahreszeitraum 2008 bis 2011), 1,78\% oder 1.071 Millionen $€(, \mathrm{MBQ}=95 \%$ “) und 1,54\% oder 926 Millionen $€(, M B Q=100 \% “)$.

Zu berücksichtigen wäre aber darüber hinaus grundsätzlich auch die Verteilung der Kasseneinnahmen auf die Entstehungsjahre. Entsprechende Zuordnungen können aus der Zahlungsstrukturstatistik abgeleitet werden. Vollständige Angaben liegen aber erst seit dem Veranlagungsjahr 2006 vor. Da in diesen Angaben bisher nur Zahlungen bis einschließlich 2011 enthalten sind, können vollständige Werte nur für die Jahre 2006 und 2007 abgeleitet werden. In diesen Jahren weichen die entsprechenden Werte nur unwesentlich vom Wert des bereinigten Kassenaufkommens ab. Vor diesem Hintergrund kann über die Verteilung auf die Jahre 2008 bis 2011 nur spekuliert werden. Im Hinblick auf die Werte für 2006 und 2007 dürfte es aber vertretbar sein, dass, wie hier, auf eine Korrektur der bereinigten Kasseneinnahmen verzichtet wird.

\footnotetext{
${ }^{13}$ Für die Gewerbesteuer ergäbe sich aus der Besteuerung von Kapitalgesellschaften ein Aufkommensrückgang in Höhe von 1,42\% oder 1.216 Millionen $€($ vier Jahre), wenn gleichzeitig die Beteiligungsquote auf $75 \%$ erhöht wird.
} 
Problematischer erscheint aber, dass auch die anzurechnenden Steuern (Kapitalertragsteuer und Zinsabschlagsteuer) das Kassenaufkommen mindern. ${ }^{14}$ Entsprechende Beträge sind aus der Körperschaftsteuerstatistik zu gewinnen, liegen aber bisher nur für die Jahre 2005 bis 2007 vor. Ein Blick auf diese Beträge zeigt, dass diese Anrechnungen erhebliches Gewicht haben. Sie machen im Durchschnitt der Jahre 2005 bis 2007 mehr als $30 \%$ der festgesetzten Körperschaftsteuer aus. Wird berücksichtigt, dass die Kasseneinnahmen um diese Anrechnungen zu erhöhen sind, wenn man das maßgebende Körperschaftsteueraufkommen identifizieren will, erhöhen sich die Aufkommensminderungen über den Vierjahreszeitraum 2008 bis 2011, gleichbleibende Verhältnisse unterstellt, auf mehr als 1,8 Milliarden $€(, M B Q=75 \% “), 1,42$ Milliarden $€(, \mathrm{MBQ}=95 \%$ “ $)$ und 1,23 Milliarden $€(, \mathrm{MBQ}=100 \%$ “). Vorbehalte sind aber auch in Bezug auf diese Zahlen zu machen, da die Ergebnisse der Statistiken für die Jahre 2005 bis 2007 aufgrund der Unternehmensteuerreform 2008 nur mit Einschränkungen für eine Projektion auf nachfolgende Jahre geeignet sind. Unter Berücksichtigung der Änderungen bei der Gewerbesteuer beläuft sich der Gesamtaufkommenseffekt auf 3,04 Milliarden $€($ „MBQ=75\%“), 2,37 Milliarden $€(, \mathrm{MBQ}=95 \%$ ") und 2,05 Milliarden $€(, \mathrm{MBQ}=100 \%$ "). Hier und im Folgenden wird davon ausgegangen, dass sich die Aufkommensänderung bei der Gewerbesteuer proportional $(1.216 / 1.825=66,31 \%)$ zur Änderung bei der Körperschaftsteuer verhält (siehe auch Fußnote 13; der deutlich geringere Effekt bei der Gewerbesteuer lässt sich inhaltlich damit begründen, dass der Verlustverrechnung bei der Gewerbesteuer aufgrund der breiteren Bemessungsgrundlage eine insgesamt geringere Bedeutung zukommt).

Tabelle D.2: Änderung des Körperschaftsteueraufkommens bei Abschaffung des EAV und alternativen Mindestbeteiligungsquoten

\begin{tabular}{|c|c|c|c|}
\hline \multicolumn{2}{|c|}{ Reformszenario } & \multirow{2}{*}{$\begin{array}{c}\text { Aufkommens- } \\
\text { änderung } \\
-2,28 \%\end{array}$} & \multirow{2}{*}{$\begin{array}{c}\text { in Bezug auf das Körperschaftsteuer- } \\
\text { aufkommen (Gewerbesteueraufkommen) } \\
2008 \text { bis } 2011 \text { (in Millionen } € \text { ) } \\
-1.825(-1.210)\end{array}$} \\
\hline 妾 & $\mathrm{MBQ}=75 \%$ & & \\
\hline 되 & $\mathrm{MBQ}=95 \%$ & $-1,78 \%$ & $-1.424(-944)$ \\
\hline 1 & $\mathrm{MBQ}=100 \%$ & $-1,54 \%$ & $-1.231(-816)$ \\
\hline
\end{tabular}

\footnotetext{
${ }^{14}$ Für die Hinweise zu den notwendigen Korrekturen der Kasseneinnahmen sind wir unseren Gesprächspartnern beim BMF, Referat IV A 6, sehr dankbar.
} 


\subsection{Weitergehende Analysen für das Basisszenario („MBQ=75\%“)}

\subsubsection{Begrenzung der Verlustverrechnung auf den Beteiligungsbuchwert}

Im Rahmen des zweiten Untersuchungsschrittes wird von der Abschaffung des Ergebnisabführungsvertrags und einer Anhebung der Mindestbeteiligungsquote auf die Höhe von $75 \%$ ausgegangen („Basisszenario“). Unter dieser Voraussetzung werden in Beantwortung einer ersten Teilfrage die Folgen für das Steueraufkommen ermittelt, wenn die Verlustverrechnung auf den Beteiligungsbuchwert begrenzt wird. Wie bereits dargestellt, werden dabei die Kasseneinnahmen bei der Hochrechnung auf das Körperschaftsteueraufkommen sowohl um Investitionszulagen, die „Altkapitalerstattungen“ und den (positiven) Saldo aus Nachzahlungs- und Erstattungszinsen bereinigt sowie Anrechnungen (Kapitalertragsteuer und Zinsabschlagsteuer) pauschal berücksichtigt. ${ }^{15}$

Tabelle D.3: Änderung des Körperschaftsteueraufkommens bei Abschaffung des EAV, MBQ $=75 \%$ und Begrenzung der Verlustverrechnung auf den Beteiligungsbuchwert

\begin{tabular}{|c|c|c|c|}
\hline \multicolumn{2}{|c|}{ Reformszenario } & \multirow{2}{*}{$\begin{array}{l}\text { Aufkommens- } \\
\text { änderung } \\
\\
+0,87 \%\end{array}$} & \multirow{2}{*}{$\begin{array}{c}\text { in Bezug auf das Körperschaftsteu- } \\
\text { eraufkommen (Gewerbesteueraufkom- } \\
\text { men) } 2008 \text { bis } 2011 \text { (in Millionen } € \text { ) } \\
+696(+462)\end{array}$} \\
\hline$\underset{\text { 离 }}{\gtrless}$ & $\begin{array}{l}\text { Begrenzung der Verlustverrech- } \\
\text { nung auf den Beteiligungsbuch- } \\
\text { wert (Methode 1) }\end{array}$ & & \\
\hline 寻 & $\begin{array}{l}\text { Begrenzung der Verlustverrech- } \\
\text { nung auf den Beteiligungsbuch- } \\
\text { wert (Methode 2) }\end{array}$ & $-1,14 \%$ & $-912(-605)$ \\
\hline
\end{tabular}

Der Beteiligungsbuchwert wird dabei in einer ersten Berechnungsweise („Methode 1“) als Produkt von Beteiligungsquote und Stammkapital des jeweiligen Tochterunternehmens ermittelt, wobei die Beteiligungsquote sowohl direkte als auch indirekte Beteiligungen berücksichtigt. ASSERT prognostiziert für dieses Reformszenario einen Aufkommenszuwachs im Vergleich zum geltenden Recht in Höhe von circa 0,9\%. Die Kombination aus der Anhebung der Mindestbeteiligungsquote auf 75\%, Abschaffung des Ergebnisabführungsvertrags und Begrenzung der Verlustverrechnung auf den Beteiligungsbuchwert würde sich danach leicht positiv auswirken. Bei der Interpretation dieses Ergebnisses ist aber zu berücksichtigen, dass die so kalkulierte Größe in einigen Fällen nicht mit dem tatsächlichen Beteiligungsbuchwert übereinstimmen dürfte. Dies sollte insbesondere dann der Fall sein, wenn ein Tochterunternehmen von der Muttergesell-

\footnotetext{
${ }^{15}$ Siehe Gliederungspunkt D.3.3.2.
} 
schaft nicht gegründet, sondern entgeltlich erworben wurde. Daneben war es mangels Datenverfügbarkeit nicht möglich, zwischenzeitliche Kapitelerhöhungen bei den Tochterunternehmen zu berücksichtigen. Daher werden an dieser Stelle die verrechenbaren Verluste tendenziell unterund insoweit der positive Aufkommenseffekt überschätzt.

Aus diesem Grund wurde der Beteiligungsbuchwert in einer zweiten Berechnungsweise („Methode 2") aus dem Finanzanlagevermögen der Muttergesellschaft abgeleitet. Nach Bundesbankstatistik entfallen durchschnittlich ein Sechstel der Finanzanlagen auf Wertpapiere. Daher wurden fünf Sechstel der Werte, die in den Jahresabschlüssen der hier betrachteten Mutterkapitalgesellschaften unter der Position „Finanzanlagevermögen“ ausgewiesen sind, nach Maßgabe der Bilanzsummen auf die korrespondierenden Tochtergesellschaften verteilt und dienen als (vorläufige) Beteiligungsbuchwerte. Diese vorläufigen Werte werden nach unten (Wertuntergrenze) durch das Produkt aus Beteiligungsquote und Stammkapital der jeweiligen Tochter begrenzt. Die Wertobergrenze bildet das Produkt aus Beteiligungsquote und dem Sechsfachen der durchschnittlichen EBITDA korrespondierender Tochtergesellschaften in den vorausgehenden fünf Jahren. ${ }^{16}$ Für diesen Fall prognostiziert ASSERT einen Aufkommensrückgang im Vergleich zum geltenden Recht in Höhe von circa -1,1\%. Es kann daher davon ausgegangen werden, dass der tatsächliche Aufkommenseffekt aufgrund einer Abschaffung des Ergebnisabführungsvertrags und Begrenzung der Verlustverrechnung auf den Beteiligungsbuchwert zwischen $+0,9$ und -1,1\% liegt, wobei dem zweiten Wert aufgrund der oben dargestellten Schwächen der ersten Berechnungsmethode eine größere Wahrscheinlichkeit zukommt.

\subsubsection{Erstreckung der Verlustverrechnung auf Vorgruppenverluste}

Die unter den Voraussetzungen des Basisszenarios („kein EAV, MBQ $=75 \%$ “) zweite Teilfrage richtet sich auf den Fall, dass sich die Verrechnung auf Verluste erstreckt, die eine Gruppengesellschaft in der Zeit vor dem Eintritt in die Steuergruppe erlitten hat. Für diesen Fall ergibt sich im Vergleich zum geltenden Recht ein prognostizierter Körperschaftsteueraufkommensrückgang in Höhe von etwa 2,85\%. Subtrahiert man den Wert von -2,28\% für die Minderung des Steueraufkommens bei „,MBQ $=75 \%$ und kein $\mathrm{EAV}$ “, ergibt sich für das Basisszenario ein isolierter Effekt aus der Einbeziehung von Vorgruppenverlusten in Höhe von -0,57\%. Bei der Übersetzung des berechneten Rückgangs in absolute Aufkommenszahlen werden erneut die Kasseneinnahmen

\footnotetext{
${ }^{16}$ Die Verwendung von „Multiples“ ist in der Praxis der Unternehmensbewertung nicht unüblich. Bei der Verwendung des Multiplikators 6 haben wir uns an durchschnittlichen Werten von „Experten-Multiples" für "Mid-Cap" und „Large-Cap“ Unternehmen (Umsatz über 50 Millionen €) orientiert, dazu Finance-Expertenpanel, Finance, Juni $2011,62-63$.
} 
bei der Hochrechnung auf das Körperschaftsteueraufkommen sowohl um Investitionszulagen, die "Altkapitalerstattungen“ und den (positiven) Saldo aus Nachzahlungs- und Erstattungszinsen bereinigt sowie Anrechnungen (Kapitalertragsteuer und Zinsabschlagsteuer) pauschal berücksichtigt. ${ }^{17}$

Tabelle D.4: Änderung des Körperschaftsteueraufkommens bei Abschaffung des EAV, MBQ $=75 \%$ und Erstreckung der Verrechnung auf Verluste, die vor Begründung der Steuergruppe entstanden sind

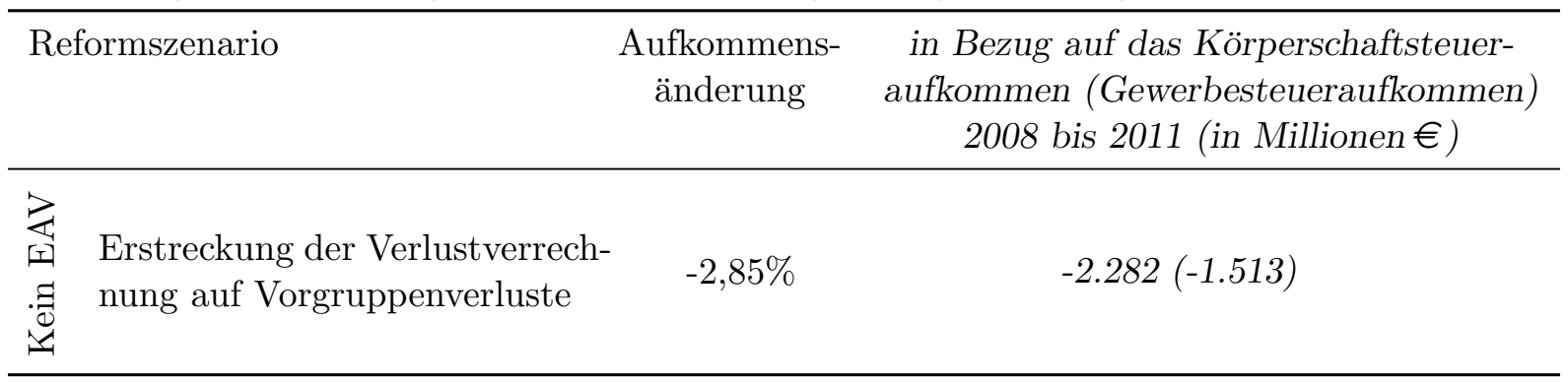

\subsubsection{Berücksichtigung der Wahrscheinlichkeit einer Inanspruchnahme der Gruppenbesteuerung}

Die dritte Teilfrage in Bezug auf das Basisszenario („kein EAV, $\mathrm{MBQ}=75 \%$ “) bezieht sich auf die Möglichkeit, dass nicht alle Konzernunternehmen, für die die Voraussetzungen vorlägen, tatsächlich einen entsprechenden Gruppenantrag stellen. Bisher wurde davon ausgegangen, dass sämtliche Konzernunternehmen, für welche die geforderte Mindestbeteiligungsquote erfüllt ist, die Option zur Gruppenbesteuerung in Anspruch nehmen. Diese Annahme muss allerdings nicht notwendigerweise zutreffend sein. Zum einen wäre auch nach Wegfall der Voraussetzung eines Ergebnisabführungsvertrags die Inanspruchnahme der Gruppenbesteuerung mit Kosten verbunden, so dass sich der Abschluss eines Gruppenvertrags nicht in jedem Fall lohnen muss. Zum anderen kann sich die Gruppenbesteuerung insbesondere für den Fall, dass Vorgruppenverluste „eingefroren“ werden, auch nachteilig erweisen.

Um Anhaltspunkte für eine mögliche Inanspruchnahme der Gruppenbesteuerung in Deutschland zu gewinnen, wurden verfügbare Statistiken über die Option zur Gruppenbesteuerung in Österreich ausgewertet, das im Zuge des österreichischen Steuerreformgesetzes 2005 die Organschaft gegen das Rechtsinstitut einer (grenzüberschreitenden) Gruppenbesteuerung ersetzt hat. ${ }^{18}$ Bei einer Übertragung dieser Erkenntnisse müsste berücksichtigt werden, dass die entsprechende Steuerreform in Österreich nicht nur einen Übergang von der Organschaft auf eine Form

\footnotetext{
${ }^{17}$ Siehe Gliederungspunkt D.3.3.2.

${ }^{18}$ Siehe (österreichisches) Steuerreformgesetz 2005, 451 der Beilagen zu den Stenographischen Protokollen des Nationalrates XXII. GP, öBGBl. I Nr. 57/2004.
} 
der Gruppenbesteuerung vorsah, sondern gleichzeitig die Verlustverrechnung für ausländische Tochterunternehmen einführte und eine deutliche Senkung des Körperschaftsteuersatzes zum Gegenstand hatte. Aus diesen Gründen erscheinen die für Österreich zu beobachtenden Wirkungen nicht vollständig vergleichbar, bilden aber die aus unserer Sicht bestmögliche Grundlage für eine Abschätzung dieses Effekts.

Einschlägige Statistiken des österreichischen Finanzministeriums zur Einführung der Gruppenbesteuerung zeigen, dass die Anzahl der Unternehmen in der Gruppenbesteuerung von 1.959 (alte Organschaft 2003) auf 13.791 (2010) angestiegen ist. ${ }^{19}$ Dieser Anstieg erfolgte allerdings nicht sprunghaft, sondern vollzog sich weitgehend kontinuierlich. Vergleicht man diese Anzahl Unternehmen mit der Summe aller Gesellschaften, die nach den vorliegenden Datenbankinformationen die Beteiligungsvoraussetzungen für die Gruppenbesteuerung erfüllen (26.128), so zeigt sich, dass auch mehr als fünf Jahre nach der Reform nur etwa die Hälfte der Unternehmen, die die einschlägigen Voraussetzungen erfüllen, die Gruppenbesteuerung tatsächlich in Anspruch nehmen. Die Ausübung dieses Optionsrechts ist dabei weder mit der Größe des Unternehmens noch der des Konzerns korreliert.

Legt man die Statistik des österreichischen Bundesministeriums für Finanzen zugrunde und geht von einer zufälligen Verteilung der optierenden Konzerne aus, ergäbe sich, dass sich der ermittelte Aufkommenseffekt zum Ende des Simulationszeitraums in etwa halbieren und in den früheren Jahren sogar noch geringer ausfallen würde. Wird allerdings unterstellt, dass lediglich jene Unternehmen für die Gruppenbesteuerung optieren, für die sich die Inanspruchnahme als vorteilhaft erweist (insbesondere Tochtergesellschaften ohne nennenswerte Verlustvorträge), dürfte der negative Aufkommenseffekt unterschätzt werden. Entsprechende Überlegungen wurden im Rahmen der Berechnungen bisher nicht berücksichtigt.

\subsection{Ergänzende Berechnungen}

\subsubsection{Mittelfristige Effekte}

Die Abschaffung des Ergebnisabführungsvertrags erweitert den Spielraum für die konzerninterne Verlustverrechnung, wenn innerhalb eines Konzerns positive und negative Einkünfte erwirtschaftet werden. Im Gegenzug entfällt jedoch der Verlustvortrag auf Ebene der Gruppengesellschaften, so dass die Minderung des Steueraufkommens insoweit temporären Charakter hat. Als eine Folge davon stehen den kurzfristigen Primäreffekten einer Abschaffung des Ergeb-

\footnotetext{
${ }^{19}$ Österreichisches Bundesministerium für Finanzen, Facts and Figures, Fachgespräch mit Dr. Maria Fekter, Steuerwettbewerb als Standortvorteil, Wien, 22. September 2011.
} 
nisabführungsvertrags in Bezug auf die Verlustverrechnung sekundäre Umkehreffekte in Folgeperioden gegenüber. Derartige Umkehreffekte können neue Primäreffekte in späteren Perioden abmildern oder überkompensieren. Zur Untersuchung der mittelfristigen Aufkommenswirkung einer Abschaffung des Gewinnabführungsvertrags unter Berücksichtigung dieser Umkehreffekte werden in Tabelle 5 die jährlichen Aufkommenseffekte für das Basisszenario und das Basisszenario bei Begrenzung der Verlustverrechnung auf den Beteiligungsbuchwert über einen Zeitraum von sechs Jahren (2008 bis 2013) berichtet. Um eine übermäßige Streuung der jährlichen Aufkommenseffekte zu vermeiden, macht diese Ausdehnung des Prognosezeitraums die Verwendung eines alternativen Hochrechnungsalgorithmus erforderlich. Dem entsprechend werden die in Tabelle 5 berichteten Aufkommenszahlen durch Hochrechnung des unternehmensspezifischen Medians der jährlichen Steuerzahlungen ermittelt. Diese Vorgehensweise führt zu einem Unterschätzen des resultierenden Aufkommenseffekts, erlaubt allerdings einen unverzerrten Blick auf die zeitliche Struktur der Aufkommensänderung.

Tabelle D.5: Mittelfristige Aufkommenseffekte

\begin{tabular}{lccc}
\hline Jahr & $\begin{array}{c}\text { Basisszenario } \\
\text { (,kein EAV, MBQ=75\%“) }\end{array}$ & $\begin{array}{c}\text { Basisszenario plus Begrenzung der } \\
\text { Verlustverrechnung auf den } \\
\text { Beteiligungsbuchwert (abgeleitet aus den } \\
\text { Finanzanlagen der Muttergesellschaft) }\end{array}$ \\
& & $\begin{array}{c}\text { im Vergleich zum } \\
\text { geltenden Recht }\end{array}$ & $\begin{array}{c}\text { im Vergleich zum } \\
\text { Basisszenario }\end{array}$ \\
\hline 2008 & $-1,97 \%$ & $-1,42 \%$ & $0,55 \%$ \\
2009 & $-1,31 \%$ & $-0,45 \%$ & $0,86 \%$ \\
2010 & $-0,52 \%$ & $1,02 \%$ & $1,54 \%$ \\
2011 & $-1,20 \%$ & $-0,14 \%$ & $1,06 \%$ \\
2013 & $-0,56 \%$ & $0,88 \%$ & $1,44 \%$ \\
Mittelwert & $-0,71 \%$ & $1,09 \%$ & $1,81 \%$ \\
\hline
\end{tabular}

Insgesamt machen die in Tabelle 5 dargestellten Ergebnisse deutlich, dass die Abschaffung des Ergebnisabführungsvertrags mit einem kurzfristigen Aufkommensrückgang verbunden ist, der sich in den Folgeperioden abschwächt oder - je nach betrachtetem Reformszenario - auch umkehrt. So sinkt für das Basisszenario das Steueraufkommen in den ersten zwei Jahren nach der Reform um 1,97 und 1,31\%, während der durchschnittliche Aufkommenseffekt für die Jahre 3 bis 6 nach der Reform mit 0,75\% deutlich geringer ausfällt. Die Ergebnisse legen nahe, dass 
der langfristige Aufkommenseffekt etwa $40 \%$ unterhalb des für über den vierjährigen Simulationszeitraums berechneten Ergebnisses liegt.

Noch deutlicher ist die zeitliche Struktur der Aufkommenseffekte bei Beschränkung der Verlustberücksichtigung auf den Beteiligungsbuchwert des Tochterunternehmens. Diese Beschränkung entfaltet in den ersten Jahren nur geringe Wirkung, der Effekt nimmt im Zeitablauf allerdings kontinuierlich zu.

\subsubsection{Abhängigkeit der Ergebnisse von der Höhe und Verteilung der körperschaftsteuer- lichen Verlustvorträge}

Vergleicht man den Bestand der Verlustvorträge in der Stichprobe mit dem Berichtswert in der Körperschaftsteuerstatistik, zeigt sich, dass die Stichprobenwerte, die auf Basis der modifizierten Jahresabschlussdaten ermittelt wurden, nicht repräsentativ sind, sondern den Bestand vielmehr unterschätzen. ${ }^{20}$ Um mögliche Einflüsse, die sich aus dieser Lücke im Bestand an Verlustvorträgen ergeben können, möglichst gering zu halten, wurden die Verlustvorträge auf Basis der Körperschaftsteuerstatistik 2004 aufgestockt, um die Abhängigkeit der hier erzielten Ergebnisse von der Höhe und Verteilung der körperschaftsteuerlichen Verlustvorträge zu analysieren. Die bestehende Lücke im Bestand der Verlustvorträge 2004 wurde ermittelt, indem pro Einkommensklasse der Grad, in dem Gewinne und Verluste in der Datenbasis erfasst sind, mit dem Grad verglichen wurde, in dem Verlustvorträge erfasst sind (siehe hierzu Tabelle 6).

Tabelle D.6: Erfassungsgrad je Einkommensklasse

\begin{tabular}{lcc}
\hline Einkommensklasse & Anzahl Unternehmen & Erfassungsgrad (in \%) \\
\hline$<-5.000 .000$ & 104 & 14,56 \\
$<-1.000 .000$ & 165 & 4,82 \\
$<-100.000$ & 261 & 1,48 \\
$<-50.000$ & 85 & 0,39 \\
$<-10.000$ & 197 & 0,25 \\
$<0$ & 155 & 0,14 \\
$=0$ & 851 & 4,30 \\
$>0$ & 567 & 0,23 \\
$>10.000$ & 1.099 & 0,55 \\
$>50.000$ & 585 & 0,82 \\
$>100.000$ & 1.996 & 2,22 \\
$>1.000 .000$ & 1.115 & 7,41 \\
$>5.000 .000$ & 591 & 21,09 \\
\hline
\end{tabular}

\footnotetext{
${ }^{20} \mathrm{Zu}$ weiteren Einzelheiten siehe Gliederungspunkt D.6.5.2
} 
Um den Bestand an Verlustvorträgen prozentual auf das sich im Hinblick auf den Anteil erfasster Gewinne und Verluste ergebende Soll anzugleichen, wurden die danach fehlenden Verlustvorträge pro Einkommensklasse aufgestockt. Dabei wurde das Defizit nach dem Verhältnis der Bilanzsummen auf die Unternehmen pro Einkommensklasse aufgeteilt. Tabelle 7 zeigt den Bestand in ASSERT erfasster Verlustvorträge im Vergleich zu den ausgewiesenen Verlustvorträgen in der Körperschaftsteuerstatistik, den Erfassungsgrad nach Hochrechnung auf alle Kapitalgesellschaften (Hochrechnung 1) und den Erfassungsgrad nach der Aufstockung des Bestands an Verlustvorträgen in der Stichprobe (Aufstockung VV). Die Ergebnisse machen deutlich, dass die unter „Aufstockung VV“ für das Jahr 2004 ausgewiesenen Verlustvorträge mit dem Anteil der in ASSERT erfassten Gewinne und Verluste korrespondieren. Vor diesem Hintergrund wird man davon ausgehen dürfen, dass in dieser Variation die auf die Stichprobe entfallenden Verlustvorträge weitgehend vollständig erfasst sind.

Auf dieser Basis zeigt eine erneute Berechnung der Aufkommenswirkungen, die mit einer Abschaffung des Ergebnisabführungsvertrags bei gleichzeitiger Anhebung der Mindestbeteiligungsquote auf $75 \%$ verbunden wäre, dass sich die Untererfassung der Verlustvorträge nicht wesentlich auf die relative Änderung des Steueraufkommens ausgewirkt hat. Während der Aufkommensrückgang im Originalmodell durchschnittlich 2,28\% beträgt, errechnet sich nach Aufstockung der Verlustvorträge ein Wert in Höhe von 2,13\%. Ähnlich dicht beieinander liegen die Ergebnisse der beiden Modelle für die Sechsjahresperiode. Zwar lässt sich nicht ausschließen, dass der aufgrund einer Abschaffung des Ergebnisabführungsvertrags tatsächlich höhere Bestand an Verlustvorträgen auf lange Sicht stärker zulasten des Steueraufkommens arbeitet. Für dieses Ergebnis zeigen sich aber in der Sechsjahresperiode keine Beweisanzeichen. Über den hier untersuchten Zeitraum hat die Untererfassung der Verlustvorträge in ASSERT jedenfalls kaum eine Bedeutung.

Tabelle D.7: Bestand der körperschaftsteuerlichen Verlustvorträge laut Körperschaftsteuerstatistik und Erfassungsgrad der Verlustvorträge in AMADEus und ASSERT in TEUR; Hochrechnung 1: Grundmodell; Aufstockung VV: Modell mit zusätzlichen Verlustvorträgen ab 2004

\begin{tabular}{lccccccc}
\hline Jahr & Destatis & AmADEus & in \% & $\begin{array}{c}\text { ASSERT } \\
\text { Hochrechnung } 1\end{array}$ & in \% & $\begin{array}{c}\text { ASSERT } \\
\text { Aufstockung VV }\end{array}$ & in \% \\
\hline 2004 & 473.375 & 8.446 & 1,78 & 56.431 & 11,92 & 207.447 & 43,82 \\
2005 & 519.370 & 9.370 & 1,80 & 65.551 & 12,62 & 166.720 & 32,10 \\
2006 & 534.154 & 10.542 & 1,97 & 76.680 & 14,36 & 178.788 & 32,47 \\
2007 & 539.472 & 13.645 & 2,53 & 100.117 & 18,56 & 199.234 & 36,93 \\
\hline
\end{tabular}




\subsection{Verteilungswirkungen}

\subsubsection{Größeneffekte}

Bisher wurde auf die Aufkommenseffekte abgestellt, die sich für die unterschiedlichen Reformszenarien einstellen würden, wenn auf die Gesamtheit aller deutschen Kapitalgesellschaften Bezug genommen wird. Die ermittelten Aufkommenswirkungen (in \%) beziehen sich mithin auf das Körperschaftsteuergesamtaufkommen. Im Unterschied dazu konzentriert sich, da wirtschaftlich selbständige Unternehmen von einer Reform nicht betroffen wären, das Interesse im Rahmen dieses dritten Untersuchungsschrittes auf die Verteilungswirkungen bei konzernzugehörigen Unternehmen. Damit sind die im Folgenden dargestellten Aufkommenswirkungen (in \%) nicht unmittelbar mit den Angaben aus den vorherigen Abschnitten vergleichbar. Sie beschränken sich auf den Teil des Körperschaftsteueraufkommens, der durch konzerngebundene Unternehmen erwirtschaftet wird. Gegenstand dieser Betrachtungen sind mögliche (1) Größeneffekte, (2) Brancheneffekte und (3) Konzernstruktureffekte. Den Ausgangspunkt bildet eine Analyse des Zusammenhangs zwischen Aufkommenswirkungen und Konzerngröße. Für Zwecke dieser Betrachtung werden die Konzernunternehmen in drei Größenklassen unterteilt.

Der für das Basisszenario ermittelte Gesamtaufkommensrückgang in Höhe von $-2,28 \%$ ist nicht für alle Konzerne mit Vorteilen verbunden. Vielmehr würde eine Umsetzung des Basisszenarios große Konzerne mit mehr als 20 Unternehmen im Vergleich zu kleineren Konzernen deutlich begünstigen. Der Rückgang bei der Steuerbelastung großer Konzerne dürfte dadurch bedingt sein, dass Risiken in großen Konzernen stärker diversifiziert sind. Andererseits ist zu berücksichtigen, dass die Mindestbesteuerung nach Gruppeneintritt lediglich auf Gruppenträgerebene und nicht auf Ebene der einzelnen Gruppengesellschaften Anwendung findet. Damit kann auch die Möglichkeit der bis zu einem Sockelbetrag von einer Million $€$ unbegrenzten Verlustverrechnung von der Gruppe nur einmal genutzt werden, so dass die Vorteile der Gruppenbesteuerung in der Einzelbetrachtung von der Diversifikation des Risikos im Konzern abhängen. Ist die Ertragsentwicklung in großen Konzernen heterogener, ist das Potenzial, Vorteile aus der Gruppenbesteuerung ziehen zu können, bei großen Konzernen höher.

Eine richtungsmäßig vergleichbare Lastenverteilung würde sich einstellen, wenn sich, entgegen der geltenden Rechtslage, die Verlustverrechnung zudem auf bestehende Vorgruppenverluste der Gruppengesellschaften erstrecken würde. Auch dieser Effekt käme stärker großen Konzernen zugute, während kleinere Konzerne isoliert betrachtet relativ schlechter gestellt würden als nach geltender Rechtslage, wenn sie tatsächlich für die Gruppenbesteuerung optieren würden. 
Tabelle D.8: Zusammenhang zwischen Aufkommenswirkungen und Konzerngröße

\begin{tabular}{|c|c|c|c|}
\hline Konzerne mit.. & $\begin{array}{c}<6 \\
\text { Konzern- } \\
\text { unternehmen }\end{array}$ & $\begin{array}{c}<21 \\
\text { Konzern- } \\
\text { unternehmen }\end{array}$ & $\begin{array}{c}>20 \\
\text { Konzern- } \\
\text { unternehmen }\end{array}$ \\
\hline Anzahl Unternehmen & 2.187 & 1.501 & 1.257 \\
\hline Basisszenario („kein EAV, MBQ $=75 \% “)$ & $+0,77 \%$ & $+0,82 \%$ & $-5,22 \%$ \\
\hline $\begin{array}{l}\text { Erstreckung der Verlustverrechnung auf Vor- } \\
\text { gruppenverluste }\end{array}$ & $+0,57 \%$ & $+0,27 \%$ & $-6,34 \%$ \\
\hline $\begin{array}{l}\text { Begrenzung der Verlustverrechnung auf den } \\
\text { Beteiligungsbuchwert (Methode 1) }\end{array}$ & $+1,60 \%$ & $+1,20 \%$ & $+1,07 \%$ \\
\hline $\begin{array}{l}\text { Begrenzung der Verlustverrechnung auf den } \\
\text { Beteiligungsbuchwert (Methode 2) }\end{array}$ & $+0,60 \%$ & $+1,42 \%$ & $-3,07 \%$ \\
\hline
\end{tabular}

Aufgrund der Möglichkeit zur Verrechnung von Vorgruppenverlusten fällt der Anstieg der Steuerbelastung bei kleinen und mittleren Konzernen hier jedoch im Vergleich zum Basisszenario geringer aus.

Auf dieses Ergebnis hat sicher auch die Annahme Einfluss, dass alle Unternehmen, die die Voraussetzungen der Gruppenbesteuerung erfüllen, diese Besteuerungsform auch in Anspruch nehmen. Tatsächlich wird man davon ausgehen können, dass insbesondere die Unternehmen, für die die Begründung einer steuerlichen Gruppe infolge hoher Vorgruppenverluste und Mindestbesteuerung unter dem Strich Nachteile mit sich bringen würde, von einer Inanspruchnahme des Optionsrechts zur Gruppenbesteuerung Abstand nehmen (vergleiche dazu auch Abschnitt D.3.4.3 und D.5).

Eine betragsmäßige Beschränkung der Verlustverrechnung auf den steuerlichen Beteiligungsbuchwert ginge für den Fiskus mit einer prognostizierten Änderung des Körperschaftsteueraufkommens in Höhe von $+0,87 \%$ oder $-1,14 \%$ einher, je nachdem welche Berechnung für die Ermittlung des Beteiligungsbuchwerts zugrunde gelegt wird (vergleiche Tabelle 3). Von einer derartigen Maßnahme negativ betroffen wären zwar grundsätzlich alle Konzerne, unabhängig von ihrer Größe, jedoch machen die Berechnungen klar, dass sich bei großen Konzernen mit mehr als zwanzig Konzerngesellschaften (das Aufkommen herabsetzende) Vorteile einstellen, wenn die Beteiligungen zu „Marktpreisen“ angesetzt werden.

\subsubsection{Brancheneffekte}

Tabelle 9 weist die Aufkommensbeiträge für die betroffenen Konzernunternehmen nach Branchenzugehörigkeit getrennt für die drei Reformszenarien aus. Im Vergleich zum geltenden Recht 
ergäbe sich danach für sowohl das einfache als auch das um die Verrechnung von Vorgruppenverlusten erweiterte Basisszenario eine Besserstellung der Konzerne, die der Baubranche angehören. Diese Branche zeichnet sich durch eine im Durchschnitt eher geringe Profitabilität aus, deren Ergebnisse um den Nullpunkt streuen. Können positive und negative Ergebnisse breiter zusammengeführt werden, wird die Verlustverrechnung beschleunigt, was Vorteile mit sich bringt. Überdurchschnittlich (wenn auch im Vergleich zur Baubranche geringer) entlastet werden dürfte in beiden Szenarien auch der Energiesektor. Darüber hinaus wird deutlich, dass auch in Bezug auf die Branchenzugehörigkeit ${ }^{21}$ die Entlastung in dem Fall, dass bestehende Verlustvorträge nicht eingefroren werden, durchweg stärker ausgeprägt ist als die zu erwartende Entlastung im Basisszenario.

Die Beschränkung der Verlustverrechnung auf den Beteiligungsbuchwert wäre zum Teil mit Aufkommenszuwächsen verbunden, wenn alle Konzerne für die Gruppenbesteuerung optieren. Ausnahmen bestehen hier vor allem für die Baubranche und das Kredit- und Versicherungsgewerbe.

Tabelle D.9: Zusammenhang zwischen Aufkommenswirkungen und Branchenzugehörigkeit

\begin{tabular}{|c|c|c|c|c|c|c|c|}
\hline Branche & $\begin{array}{l}\text { Verarbeiten- } \\
\text { des Gewerbe }\end{array}$ & Energie & $\begin{array}{l}\text { Bau- } \\
\text { gewerbe }\end{array}$ & Handel & $\begin{array}{l}\text { Finanz- } \\
\text { institute }\end{array}$ & $\begin{array}{l}\text { Dienst- } \\
\text { leistungen }\end{array}$ & Übrige \\
\hline Anzahl Unternehmen & 1.541 & 391 & 317 & 841 & 347 & 557 & 951 \\
\hline $\begin{array}{l}\text { Basisszenario („kein } \\
\mathrm{EAV}, \mathrm{MBQ}=75 \% \text { “) }\end{array}$ & $-2,21$ & $-4,69$ & $-19,77$ & $-0,15$ & $-1,45$ & $-1,11$ & $-1,71$ \\
\hline $\begin{array}{l}\text { Erstreckung der Ver- } \\
\text { lustverrechnung auf } \\
\text { Vorgruppenverluste }\end{array}$ & $-2,70$ & $-5,92$ & $-19,96$ & $-0,11$ & $-1,62$ & $-3,90$ & $-2,71$ \\
\hline $\begin{array}{l}\text { Begrenzung der Ver- } \\
\text { lustverrechnung auf } \\
\text { den Beteiligungsbuch- } \\
\text { wert (Methode 1) }\end{array}$ & $+0,29$ & $+3,79$ & $-13,66$ & $+1,32$ & $-1,60$ & $+1,43$ & $+3,83$ \\
\hline $\begin{array}{l}\text { Begrenzung der Ver- } \\
\text { lustverrechnung auf } \\
\text { den Beteiligungsbuch- } \\
\text { wert (Methode 2) }\end{array}$ & $-0,23$ & $-4,05$ & $-12,10$ & $+1,18$ & $-3,65$ & $+1,04$ & $+0,41$ \\
\hline
\end{tabular}

\subsubsection{Konzernstruktureffekte}

Abschließend sollen die berechneten Aufkommenseffekte daraufhin untersucht werden, wie sie sich auf reine Inlandskonzerne („Nationale Konzerne“), inländische Konzerne mit Auslandsakti-

\footnotetext{
${ }^{21}$ Die Konzernbranche ergibt sich aus den Tätigkeitsfeldern der einzelnen Konzerngesellschaften (NACE). Maßgebend sind hierbei die absoluten oder relativen Wertschöpfungsanteile; dazu ausführlich Poppe, Fußnote 9, 119-121.
} 
vitäten („Outbound-Konzerne“) und ausländische Konzerne mit Inlandsaktivitäten („InboundKonzerne“) aufteilen. Die nachstehende Tabelle 10 gibt Auskunft zu dieser Frage. Dabei wird von einem „Outbound-Konzern“ ausgegangen, wenn eine in Deutschland ansässige Konzernmuttergesellschaft mittelbar oder unmittelbar mindestens eine Tochtergesellschaft hält, die in einem anderen Land ansässig ist. Umgekehrt ist von einem „Inbound-Konzern“ auszugehen, wenn die Konzernmuttergesellschaft der in Deutschland aktiven Konzerngesellschaften im Ausland ansässig ist. In allen Fällen beschränken sich die ermittelten Werte jedoch auf die in Deutschland ansässigen Gesellschaften.

Tabelle D.10: Zusammenhang zwischen Aufkommenswirkungen und Konzernstruktur

\begin{tabular}{|c|c|c|c|}
\hline Konzernstruktur & $\begin{array}{l}\text { Nationale } \\
\text { Konzerne }\end{array}$ & $\begin{array}{l}\text { Outbound- } \\
\text { Konzerne }\end{array}$ & $\begin{array}{l}\text { Inbound- } \\
\text { Konzerne }\end{array}$ \\
\hline Anzahl Unternehmen & 2.691 & 1.168 & 1.086 \\
\hline Basisszenario („kein EAV, MBQ $=75 \% “)$ & $+0,97 \%$ & $-5,51 \%$ & $-0,75 \%$ \\
\hline $\begin{array}{l}\text { Erstreckung der Verlustverrechnung auf Vor- } \\
\text { gruppenverluste }\end{array}$ & $+0,71 \%$ & $-6,56 \%$ & $-1,66 \%$ \\
\hline $\begin{array}{l}\text { Begrenzung der Verlustverrechnung auf den } \\
\text { Beteiligungsbuchwert (Methode } 1 \text { ) }\end{array}$ & $+2,31 \%$ & $-0,11 \%$ & $+2,63 \%$ \\
\hline $\begin{array}{l}\text { Begrenzung der Verlustverrechnung auf den } \\
\text { Beteiligungsbuchwert (Methode 2) }\end{array}$ & $+0,73 \%$ & $-2,99 \%$ & $-0,05 \%$ \\
\hline
\end{tabular}

Die für die Gesellschaften internationaler Konzerne (Inbound- und Outbound-Konzerne) ermittelten Ergebnisse korrespondieren mit den Ergebnissen, die für große Kapitalgesellschaften berechnet wurden (Gliederungspunkt 3.6.1). Da internationale Konzerne durch einen überdurchschnittlich hohen Anteil großer Konzerne gekennzeichnet sind (50,00\% bei Outbound-Konzernen, 46,59\% bei Inbound-Konzernen), überrascht nicht, dass sich internationale Konzerne (und hier insbesondere Outbound-Konzerne) durch den Wegfall der Voraussetzung eines Ergebnisabführungsvertrags besser stellen würden. Hiermit im Einklang steht auch die Beobachtung, dass nationale Konzerne im Vergleich zum geltenden Recht mehr belastet würden, soweit die Gruppenbesteuerung durchgängig in Anspruch genommen werden würde. In der Stichprobe ist bei den nationalen Konzernen der Anteil großer Konzerne mit einem Wert von 6,21\% stark unterrepräsentiert. 


\section{Hochrechnung der finalen ausländischen Verluste zum Jahresende 2008}

\subsection{Vorgehensweise}

Das IFSt-Modell sieht auch die Verrechenbarkeit finaler Verluste ausländischer Tochterunternehmen auf Ebene des inländischen Mutterunternehmens vor. Eine Berechnung der hiermit voraussichtlich einhergehenden Aufkommenseffekte kann aufgrund der fehlenden Bestimmbarkeit finaler Verlust nicht mit Hilfe von ASSERT vorgenommen werden. Um dennoch eine Bandbreite angeben zu können, innerhalb derer sich der Bestand an finalen Auslandsverlusten bewegen dürfte, erfolgt eine erste Hochrechnung unter Bezug auf die Eurostat- und die AmadeusDatenbank sowie die Direktinvestitionsstatistik der Deutschen Bundesbank des Jahres 2008, sowie eine zweite Hochrechnung, die sich neben der AMADEus-Datenbank auf die letztverfügbare Körperschaftsteuerstatistik des Jahres 2007 stützt.

\subsection{Hochrechnung auf Basis der Direktinvestitionsstatistik 2008}

\subsubsection{Gesamtbestand an Verlustvorträgen in Bezug auf ausländische Tochtergesellschaften deutscher Konzerne}

ASSERT unterstützt die Berechnung bestehender Verlustvorträge in Bezug auf die im Ausland ansässigen inaktiven Tochtergesellschaften deutscher Mutterunternehmen. Daher lässt sich für die inaktiven ausländischen Tochtergesellschaften deutscher Mutterunternehmen der prozentuale Anteil der durch Fortschreibung ermittelten Verlustvorträge an der Bilanzsumme berechnen. Da aber nicht davon auszugehen ist, dass AmADEus den tatsächlichen Bestand an inaktiven Auslandstöchtern über alle betrachteten Investitionsländer in vergleichbar geeigneter Weise erfasst, wird für die weiteren Schritte der länderübergreifende Quotient aus der Summe aller in 2008 bestehenden Verlustvorträge inaktiver Auslandstöchter (circa 3,60 Milliarden $€$ ) und der Summe aller letztberichteten Bilanzsummen dieser Töchter (circa 25,39 Milliarden€) verwendet. Dieser Quotient beläuft sich auf 14,16\%. Demnach weist jede inaktive ausländische Tochtergesellschaft eines deutschen Unternehmens im Jahr 2008 pro $100 €$ Bilanzsumme im Durchschnitt einen Bestand an vorgetragenen steuerlichen Verlusten in Höhe von 14,16€auf.

Im Gegensatz zur Amadeus-Datenbank zeichnet sich die Direktinvestitionsstatistik der Deutschen Bundesbank durch eine Vollerfassung der ausländischen Direktinvestitionen deutscher Un- 
ternehmen aus, insbesondere gibt sie auch für jedes Investitionsland die Summen der Bilanzsummen aller ausländischen Direktinvestitionen wieder. Durch Multiplikation des landesspezifischen Gesamtbestands der Bilanzsummen mit dem über alle Investitionsländer gemittelten Verlustvortragsquotienten folgt hieraus eine Schätzung für den landesspezifischen Bestand an vorgetragenen Verlusten deutscher Auslandstöchter zum Jahresende 2008.

\subsubsection{Finale Verluste in Bezug auf ausländische Tochtergesellschaften deutscher Konzerne}

Die „Finalität“ eines Auslandsverlusts setzt voraus, dass dieser Verlust im Ausland unter keinen Umständen anderweitig verwertbar ist. Dabei darf die endgültige Verrechenbarkeit nicht Folge steuerrechtlicher Bestimmungen des Auslands sein, sondern muss auf faktischen Gegebenheiten beruhen. Regelmäßig sind hiermit Verluste infolge einer Unternehmensliquidation und -beendigung angesprochen.

Eurostat dokumentiert jahres- und landesspezifische Schließungsraten, die den Anteil der Unternehmensschließungen eines Jahres an den aktiven Unternehmen dieses Jahres angeben. In diese Schließungsraten finden jedoch nicht nur die Schließungen deutscher Auslandstöchter, sondern alle Unternehmensschließungen Eingang. Fraglich könnte demnach die methodische Zulässigkeit einer Verknüpfung dieser Schließungsrate mit den auf deutsche Auslandstöchter begrenzten Daten aus der AmADEus-Datenbank sein. Ein Vergleich des länderübergreifenden Anteils aller inaktiven Unternehmen an der Gesamtheit aller Unternehmen (10,95\%) mit dem gleichfalls länderübergreifenden Anteil aller inaktiven Auslandstöchter deutscher Unternehmen an der Gesamtheit aller Auslandstöchter deutscher Unternehmen (10,50\%) zeigt aber, dass diese beiden Quotienten nicht signifikant voneinander verschieden sind. Die Verknüfung der EUROSTAT-Schließungsrate mit AmADEus-Daten sollte daher zulässig sein.

Vor diesem Hintergrund werden im Folgenden für jedes Land die Mittelwerte der Schließungsraten für den Zeitraum 2000 bis 2008 ermittelt. Durch Multiplikation des landesspezifischen Bestands an vorgetragenen Verlusten mit der gemittelten, landesspezifischen Schließungsrate ergeben sich die hochgerechneten landesspezifischen finalen Verluste, die der deutsche Fiskus zur Verrechnung im Inland zulassen müsste. Legt man zum Beispiel für Österreich (AT, Tabelle 11, Zeile 1) eine Bilanzsumme in Höhe von 41.900.000 $\mathrm{T} €$ zugrunde und multipliziert diese mit dem oben dargestellten Verlustanteil in Höhe von 14,16\% sowie der für AT landestypischen Schließungsrate in Höhe von 3,39\%, ergibt sich ein finaler Verlust in Höhe von $41.900 .000 \times 14,16 / 100 \times 3,39 / 100=201.130,056 \mathrm{~T} €$ oder (abgerundet) ein Betrag in Höhe von $201.100 \mathrm{~T} €$. 
Tabelle D.11: Hochrechnung der finalen Auslandsverluste auf Basis der Direktinvestitionsstatistik 2004

\begin{tabular}{|c|c|c|c|c|}
\hline 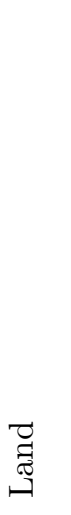 & 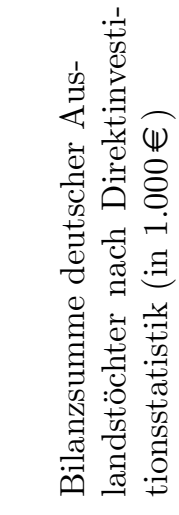 & 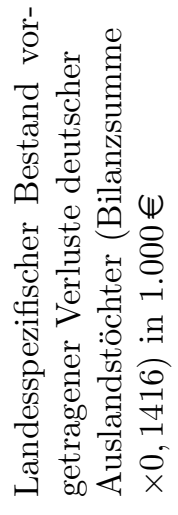 & 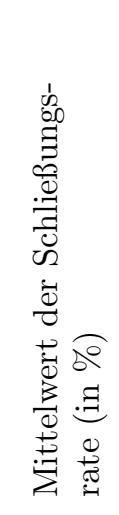 & 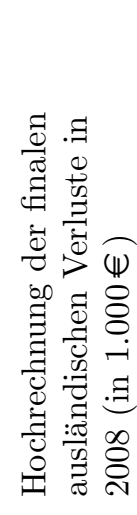 \\
\hline $\mathrm{AT}$ & 41.900 .000 & 5.933 .040 & 3,39 & 201.100 \\
\hline $\mathrm{BE}$ & 31.400 .000 & 4.446 .240 & 2,79 & 124.000 \\
\hline $\mathrm{BG}$ & 2.300 .000 & 325.680 & 6,69 & 21.800 \\
\hline $\mathrm{CY}$ & 100.000 & 14.160 & 2,23 & 300 \\
\hline $\mathrm{CZ}$ & 25.900 .000 & 3.667 .440 & 6,54 & 239.800 \\
\hline DK & 5.400 .000 & 764.640 & 6,47 & 49.400 \\
\hline $\mathrm{EE}$ & 400.000 & 56.640 & 8,81 & 5.000 \\
\hline $\mathrm{ES}$ & 38.800 .000 & 5.494 .080 & 4,35 & 238.900 \\
\hline FI & 8.200 .000 & 1.161 .120 & 4,53 & 52.600 \\
\hline $\mathrm{FR}$ & 67.100 .000 & 9.501 .360 & 4,72 & 448.100 \\
\hline GR & 4.800 .000 & 679.680 & $5,99^{*}$ & 40.700 \\
\hline $\mathrm{HU}$ & 15.600 .000 & 2.208 .960 & 6,92 & 152.800 \\
\hline IE & 4.800 .000 & 679.680 & $5,99^{*}$ & 40.700 \\
\hline IT & 43.000 .000 & 6.088 .800 & 5,79 & 352.200 \\
\hline $\mathrm{LT}$ & 700.000 & 99.120 & 6,22 & 6.200 \\
\hline $\mathrm{LU}$ & 1.300 .000 & 184.080 & 7,80 & 14.400 \\
\hline LV & 300.000 & 42.480 & 70,10 & 3.000 \\
\hline MT & 200.000 & 28.320 & 3,67 & 1.000 \\
\hline NL & 18.100 .000 & 2.562 .960 & 6,60 & 169.000 \\
\hline PL & 23.100 .000 & 3.270 .960 & $5,99^{*}$ & 195.900 \\
\hline $\mathrm{PT}$ & 8.800 .000 & 1.246 .080 & 6,36 & 79.200 \\
\hline $\mathrm{RO}$ & 7.800 .000 & 1.104 .480 & 10,76 & 118.800 \\
\hline $\mathrm{SE}$ & 24.600 .000 & 3.483 .360 & 3,42 & 119.100 \\
\hline SI & 2.000 .000 & 283.200 & 4,47 & 12.600 \\
\hline SK & 8.900 .000 & 1.260 .240 & 7,72 & 97.300 \\
\hline UK & 46.500 .000 & 6.584 .400 & 10,57 & 695.800 \\
\hline
\end{tabular}

\footnotetext{
* Da für Griechenland, Irland und Polen keine Mittelwerte der Schließungsrate verfügbar sind, wird ersatzweise
} der Durschnitt aller übrigen Länder herangezogen. 
Tabelle 11 gibt die einzelnen Hochrechnungsparameter detailliert wieder und weist einen hochgerechneten Bestand finaler Auslandsverluste in Höhe von etwa 3,48 Milliarden $€$ zum Jahresende 2008 auf. Wie in Abschnitt D.6.3.1 dargelegt, geht die in ASSERT separat erfolgende Simulation der steuerlichen Verlustvorträge mangels Datenverfügbarkeit für alle in die Simulation einbezogenen Unternehmen von einem Anfangsbestand im Jahr 1994 in Höhe von null € aus. Aus diesem Grund muss unterstellt werden, dass die nachstehend ausgewiesene Hochrechnung, in die die simulierten Verlustvorträge einfließen, den tatsächlichen Bestand an finalen Auslandsverlusten tendenziell unterschätzt. Diese Unterschätzung dürfte jedoch nicht das Ausmaß haben, dass für deutsche Unternehmen festgestellt wurde (Abschnitt D.6.5.2), da die Datenlage in Bezug auf ausländische Unternehmen insgesamt besser ist.

Multipliziert man den resultierenden Betrag in Höhe von 3,48 Milliarden $€$ mit der kombinierten Tarifsteuerbelastung aus Körperschaftsteuer und Solidaritätszuschlag (15,83\%), ergibt sich für die Minderung des Steueraufkommens ein Betrag in Höhe von 550,8 Millionen $€$. Wird ferner unterstellt, dass nur circa $75 \%$ der Muttergesellschaften im Inland Gewinne erzielen, ${ }^{22}$ reduziert sich dieser Wert auf einen Betrag von 415,3 Millionen $€$. Geht man mit dem BFH davon aus, dass finale Verluste in die Ermittlung des Gewerbeertrags einzubeziehen sind, ${ }^{23}$ erhöht sich die maßgebende Tarifbelastung auf 29,83\%, sie hat Aufkommensminderungen in Höhe von 1.043,4 Millionen $€$ oder 782,5 Millionen $€(75 \%)$ zur Folge. ${ }^{24}$

\subsection{Hochrechnung auf Basis der Körperschaftsteuerstatistik 2007}

Die aktuelle Körperschaftsteuerstatistik bezieht sich auf das Jahr 2007 und weist, untergliedert nach Unternehmen, die nach finanzieller Rechnungslegung einen Gewinn („Gewinnunternehmen“) oder Verlust („Verlustunternehmen“) berichten, unter anderem die Summen von Bilanzgewinnen und -verlusten sowie die exakten Bestände der steuerlichen Verlustvorträge zum 31.12.2007 aus.

Anhand dieser Daten lassen sich Verlustvortragsquotienten berechnen, die angeben, wie viel $€$ Verlustvortrag durchschnittlich auf einen $€$ Bilanzgewinn beziehungsweise Bilanzverlust entfallen. Nach Tabelle 12 verfügen Gewinnunternehmen pro $€$ Bilanzgewinn durchschnittlich über steuerliche Verlustvorträge in Höhe von 0,9975€, während Verlustunternehmen pro € Bilanz-

\footnotetext{
${ }^{22} \mathrm{Zu}$ diesem Ansatz Fellinger und Schmidt-Fehrenbacher, Ubg 2012, 221; ähnlich Oestreicher, Scheffler, Spengel und Wellisch, Modelle einer Konzernbesteuerung für Deutschland und Europa, 2008, 408. Allerdings nimmt die genannte Studie Bezug auf die gesamten Auslandsverluste und nicht, wie hier, finale Auslandsverluste.

${ }^{23}$ Vgl. BFH, Urteil vom 09.06.2010 I R 107/109, BStBl II 2009, 630.

${ }^{24}$ Diese Schätzungen liegen innerhalb einer Bandbreite der Werte, die sich nach den (methodisch völlig verschiedenen) Berechnungen des BDI auf Basis der durchschnittlichen Jahresfehlbeträge laut Bundesbankstatistik ergeben, dazu Fellinger und Schmidt-Fehrenbacher, Ubg 2012, 217-222.
} 
verlust im Durchschnitt einen steuerlichen Verlustvortrag in Höhe von $4,554 €$ vorweisen.

Tabelle D.12: Höhe der Verlustvorträge und Bilanzergebnis nach Körperschaftsteuerstatistik

\begin{tabular}{|c|c|c|c|}
\hline \multicolumn{2}{|l|}{ Alle Angaben zum 31.12.2007 } & $\begin{array}{l}\text { Unternehmen mit } \\
\text { Bilanzgewinn }\end{array}$ & $\begin{array}{l}\text { Unternehmen mit } \\
\text { Bilanzverlust }\end{array}$ \\
\hline \multirow{3}{*}{$\begin{array}{l}\text { Summe der Bilanzgewinne } \\
\text { (in } 1.000 € \text { ) }\end{array}$} & $\begin{array}{l}\text { Positiver Gesamtbetrag } \\
\text { der Einkünfte }\end{array}$ & 188.250 .488 & \\
\hline & $\begin{array}{l}\text { Negativer Gesamtbetrag } \\
\text { der Einkünfte }\end{array}$ & 25.440 .883 & \\
\hline & Summe & 213.691.371 & \\
\hline \multirow{3}{*}{$\begin{array}{l}\text { Summe der Bilanzverluste } \\
\text { (in } 1.000 € \text { ) }\end{array}$} & $\begin{array}{l}\text { Positiver Gesamtbetrag } \\
\text { der Einkünfte }\end{array}$ & & 13.206 .343 \\
\hline & $\begin{array}{l}\text { Negativer Gesamtbetrag } \\
\text { der Einkünfte }\end{array}$ & & 58.449 .468 \\
\hline & Summe & & 71.655 .811 \\
\hline \multicolumn{2}{|c|}{$\begin{array}{l}\text { Bestände der steuerlichen Verlustvorträge } \\
\text { der Unternehmen mit Bilanzgewinn } \\
\text { (in } 1.000 €)\end{array}$} & 213.153.014 & \\
\hline \multicolumn{2}{|c|}{$\begin{array}{l}\text { Bestände der steuerlichen Verlustvorträge } \\
\text { der Unternehmen mit Bilanzverlust } \\
\text { (in } 1.000 € \text { ) }\end{array}$} & & 326.318 .907 \\
\hline \multicolumn{2}{|l|}{$\begin{array}{l}\text { Verlustvortragsquotient der } \\
\text { Gewinnunternehmen }\end{array}$} & 0,9975 & \\
\hline \multicolumn{2}{|l|}{$\begin{array}{l}\text { Verlustvortragsquotient der } \\
\text { Verlustunternehmen }\end{array}$} & & 4,554 \\
\hline
\end{tabular}

Die Amadeus-Datenbank weist die Handelsbilanzgewinne und -verluste der inaktiven ausländischen Tochtergesellschaften deutscher Mutterunternehmen aus. Danach summieren sich die Bilanzergebnisse der ausländischen inaktiven Gewinnunternehmen, das heißt die Bilanzgewinne, auf circa 1,503 Milliarden $€$ und die Bilanzergebnisse der ausländischen inaktiven Verlustunternehmen, das heißt die Bilanzverluste, auf circa 2,452 Milliarden $€$. Durch Multiplikation dieser Bilanzergebnisse mit den jeweiligen Verlustvortragsquotienten (Tabelle 12) ergibt sich der hochgerechnete Bestand an finalen, in Deutschland verrechenbaren Auslandsverlusten für die Gewinnunternehmen mit circa 1,5 Milliarden $€$ und für die Verlustunternehmen mit circa 11,17 Milliarden €. Multipliziert man diese Beträge mit Tarifbelastungen in Höhe von 15,83\% bzw. 29,83\% und unterstellt, dass nur circa $75 \%$ der Muttergesellschaften im Inland Gewinne erzielen, ergeben sich hieraus Minderungen in der Größenordnung von 1,5 Milliarden $€$ bzw. 2,83 Milliarden $€$.

Grundsätzlich ist allerdings zu erwarten, dass im Hinblick auf die methodische Stringenz des Berechnungsansatzes die erste Hochrechnung auf Basis der Direktinvestitionsstatistik in ihrer 
Tendenz eher an den tatsächlichen Bestand der finalen Auslandsverluste in 2008 heranreicht als die Hochrechnung auf Basis der Körperschaftsteuerstatistik.

\section{Zusammenfassende Würdigung der Berechnungsergebnisse}

Die Ergebnisse unserer Berechnungen legen nahe, dass die Abschaffung der Voraussetzung eines Ergebnisabführungsvertrags für die Bildung einer ertragsteuerlichen Organschaft auch dann mit Aufkommenswirkungen verbunden sein dürfte, wenn gleichzeitig die hierfür notwendige Mindestbeteiligungsquote angehoben wird. Ein Vergleich dieser Ergebnisse mit den Zahlen, die von der Arbeitsgruppe des Bundesfinanzministeriums ermittelt wurden („Aufkommensverlust im mittleren bis hohen einstelligen Milliardenbereich“), ist allerdings nur mit Einschränkungen möglich. So beziehen sich die hier berichteten Zahlen erstens auf eine Vierjahresperiode, während das Bundesfinanzministerium auf Jahreswirkungen abstellt. Zweitens beschränken sich die Berechnungen mithilfe von ASSERT auf die laufende Steuerbelastung von Kapitalgesellschaften, wenngleich daneben auch die Höhe „finaler Verluste“ außerhalb von ASSERT ermittelt und separat ausgewiesen wird. Die Bedeutung für das Steueraufkommen betroffener Personengesellschaften wurde bisher nicht berücksichtigt. Drittens beziehen sich die Angaben auf unterschiedliche Zeiträume. Während das Modell ASSERT auf einer Fortschreibung historischer Jahresabschlussdaten beruht, die sich gegenwärtig auf den Zeitraum (und die wirtschaftliche Entwicklung der Jahre) 2008 bis 2012 erstreckt, beziehen sich die Schätzungen des Bundesfinanzministeriums auf den Zeitraum (und die volkswirtschaftliche Gesamtrechnung) ab 2013. Um einen Vergleich beider Schätzungen zu erleichtern, sollen die mithilfe von ASSERT ermittelten Ergebnisse entsprechend ergänzt und auf eine Jahreswirkung verdichtet werden. Hierzu sind weitere Annahmen erforderlich, die im Folgenden näher begründet werden. Die wesentlichen Ergebnisse dieser Betrachtung sind in Tabelle 13 zusammengefasst.

Ausgangspunkt für die Abschätzung des Gesamtaufkommenseffekts bilden die für das Basisszenario („kein EAV, MBQ=75\%”) ermittelten Aufkommensänderungen, die sich unter Berücksichtigung der Besteuerung von Kapitalgesellschaften für die Körperschaftsteuer und Gewerbesteuer ergeben (siehe Tabelle 2). Für Zwecke des vollständigen Ausweises der in Bezug auf Kapitalgesellschaften erwarteten Steuerfolgen wird die Änderung des Körperschaftsteueraufkommens um die korrespondierende Änderung des Solidaritätszuschlags erhöht und die sich ergebenden Aufkommenswirkungen für die Alternativen „mit Verrechnung von Vorgruppenverlusten während der Gruppenzugehörigkeit“ und „ohne Verrechnung von Vorgruppenverlusten während der Grup- 
Tabelle D.13: Erwartete Aufkommensänderungen aus einer Abschaffung des Gewinnabführungsvertrags und einer Berücksichtigung finaler Auslandsverluste

\begin{tabular}{|c|c|c|c|}
\hline & Angaben in Millionen $€$ & $\begin{array}{l}\text { Ohne Verrechnung } \\
\text { von Vorgruppen- } \\
\text { verlusten }\end{array}$ & $\begin{array}{l}\text { Mit Verrechnung } \\
\text { von Vorgruppen- } \\
\text { verlusten }\end{array}$ \\
\hline \multirow[t]{4}{*}{+} & $\begin{array}{l}\text { Erwartete Aufkommensänderungen (auf der } \\
\text { Basis von Berechnungen mit Hilfe von } \\
\text { ASSERT) aus der Besteuerung von Kapital- } \\
\text { gesellschaften („kein EAV, MBQ=75\%”) }\end{array}$ & & \\
\hline & Körperschaftsteuer & $-1.825,00$ & $-2.282,00$ \\
\hline & Gewerbesteuer & $-1.210,00$ & $-1.513,00$ \\
\hline & Solidaritätszuschlag & $-100,38$ & $-125,51$ \\
\hline+ & $\begin{array}{l}\text { Erwartete Aufkommensänderung aus der } \\
\text { Besteuerung von Personengesellschaften }\end{array}$ & $-1.347,76$ & $-1.685,26$ \\
\hline$=$ & $\begin{array}{l}\text { Erwarteter Gesamteffekt einer verpflichtenden } \\
\text { Einführung (ohne Auslandsverluste) für den } \\
\text { Zeitraum } 2008 \text { bis } 2011\end{array}$ & $-4.483,14$ & $-5.605,77$ \\
\hline+ & Übertragung auf Vierjahreszeitraum 2013-2016 & $-2.850,94$ & $-3.564,85$ \\
\hline+ & $\begin{array}{l}\text { Auswirkungen einer nicht vollständigen } \\
\text { Inanspruchnahme der Gruppenbesteuerung }\end{array}$ & $+1.833,52$ & $+2.292,65$ \\
\hline$=$ & $\begin{array}{l}\text { Erwarteter Gesamteffekt einer optionalen } \\
\text { Einführung (ohne Auslandsverluste) für den } \\
\text { Zeitraum } 2013 \text { bis } 2016\end{array}$ & $-5.500,56$ & $-6.877,96$ \\
\hline$\times$ & $\begin{array}{l}0,25 \\
\text { (durchschnittlicher Jahreseffekt) }\end{array}$ & $-1.375,14$ & $-1.719,49$ \\
\hline+ & $\begin{array}{l}\text { Berücksichtigung finaler Auslandsverluste } \\
\text { (Körperschaftsteuer und Gewerbesteuer) }\end{array}$ & $-782,50$ & $-782,50$ \\
\hline$=$ & Erwarteter Jahreseffekt (mit Auslandsverlusten) & $-2.157,64$ & $-2.501,99$ \\
\hline
\end{tabular}

penzugehörigkeit" einander vergleichend gegenübergestellt.

Die Aufkommensberechnungen in ASSERT sind beschränkt auf die Besteuerung von Kapitalgesellschaften, da notwendige Angaben zu Personengesellschaften in der zugrundeliegenden Datenbasis nur unzureichend erfasst sind und Berechnungen für die Einkommensteuer nur mit weitreichenden Annahmen hinsichtlich der maßgeblichen Steuersätze möglich wären. Da der Vorschlag des IFSt Gruppenträger in der Rechtsform einer Personengesellschaft zulässt, wäre eine Abschätzung der Aufkommenswirkungen ohne Berücksichtigung dieser Unternehmen unvollständig. Aus diesem Grund wurde die erwartete Wirkung der Einführung der Gruppenbesteuerung auf das aus der Besteuerung von Personengesellschaften resultierende Ertragsteueraufkommen (außerhalb von ASSERT) gesondert geschätzt. Als Datenbasis dienten eine Stichprobe 
von Personengesellschaften, die mindestens eine Tochterkapitalgesellschaft halten, und die Gewerbesteuerstatistiken für die Jahre 2004 und 2007. Aus diesen Gewerbesteuerstatistiken ergibt sich, dass die Anzahl und der Gewerbeertrag bei Organträgern, die in der Rechtsform einer Personengesellschaft betrieben werden, in einer Größenordnung von 10\% bis 35\% der Werte liegen, die für Organträger in der Rechtsform einer Kapitalgesellschaft beobachtet werden. Da zudem gezeigt werden kann, dass sich der Anteil tatsächlich begründeter Organschaften an der Gesamtheit aller denkbaren Organschaftsbeziehungen, die aufgrund der Beteiligungsstruktur möglich sind, in Abhängigkeit von der Rechtsform nicht wesentlich unterscheidet, wird davon ausgegangen, dass die Verbesserung der Verlustverrechnungsmöglichkeiten mit einer Verringerung der Bemessungsgrundlage in Höhe eines Viertels der entsprechenden Werte für Kapitalgesellschaften einhergeht. Für die Umrechnung in Aufkommensänderungen wurde ein durchschnittlicher Ertragsteuersatz von $42 \%$ zuzüglich Solidaritätszuschlag unterstellt, was zu einer erwarteten Aufkommensminderung in Höhe von 1,3 und 1,7 Milliarden $€$ führt. Diese Zahlen berücksichtigen noch nicht, dass die Gruppenbesteuerung bei Gruppenträgern in der Rechtsform einer Personengesellschaft ferner dazu führt, dass die Einkommen der Gruppengesellschaften vollständig mit Einkommensteuer (und anrechenbarer Gewerbesteuer) anstelle von Körperschaftsteuer, Gewerbesteuer und Einkommensteuer nach Maßgabe des Teileinkünfteverfahrens bei Ausschüttung belastet werden. Der hieraus resultierende Effekt kann ohne detaillierte Kenntnis der maßgebenden Einkommensteuersätze nicht zuverlässig quantifiziert werden. Bei Unterstellung eines Einkommensteuersatzes von $42 \%$ und eines Gewerbesteuerhebesatzes von $400 \%$ wäre die Option für die Gruppenbesteuerung allerdings nur bei annähernd vollständiger Ausschüttung der Gewinne auf Ebene der Tochtergesellschaft mit positiven Tarifeffekten verbunden. ${ }^{25}$ Da zudem davon ausgegangen werden kann, dass Tochtergesellschaften nicht für die Gruppenbesteuerung optieren, wenn diese mit wesentlichen Tarifnachteilen verbunden wäre, wird hier unterstellt, dass keine weiteren Aufkommenseffekte resultieren.

Für die Umrechnung der relativen Aufkommensänderung in absolute Beträge wurden die (realisierten oder prognostizierten) Körperschaftsteuer- und Gewerbesteuereinnahmen der Jahre 2008 bis 2012 zugrunde gelegt. Diese Vorgehensweise ist systematisch richtig, da sich auch die Prognose der relativen Aufkommensänderung auf diesen Zeitraum bezieht. Andererseits dürfte dieser Ansatz jedoch mit einer Unterschätzung des aus einer Umsetzung der Reform zum 1.1.2013 resultierenden Aufkommenseffekts verbunden sein, da die Körperschaftsteueraufkommen für die

\footnotetext{
${ }^{25}$ Eine Auswertung für eine Unternehmensstichprobe aus der AmADEus-Datenbank ergibt, dass die Ausschüttungsquote bei Tochterkapitalgesellschaften in dieser Konstellation im Durchschnitt bei lediglich $30 \%$ liegt.
} 
Jahre 2013 bis 2015 im Durchschnitt deutlich höher ausfallen werden. Zur Berücksichtigung dieses Umstands wurde die zuvor ermittelte Aufkommensänderung um den Faktor 1,64 erhöht. Dieser Faktor spiegelt das Verhältnis von durchschnittlich erwartetem Körperschaftsteueraufkommen der Jahre 2013 bis 2015 und durchschnittlich (erwartetem oder realisiertem) Körperschaftsteueraufkommen der Jahre 2008 bis 2012 wider.

Schließlich muss berücksichtigt werden, dass die Gruppenbesteuerung nicht verpflichtend, sondern auf optionaler Basis eingeführt werden soll. Die Erfahrungen in Österreich haben gezeigt, dass kurz- und mittelfristig das Wahlrecht zur Gruppenbesteuerung nur in etwa der Hälfte der möglichen Fälle ausgeübt wurde (siehe Kapitel D.3.4.3). Wird unterstellt, dass Unternehmen in Deutschland in vergleichbarer Weise zurückhaltend auf die Reform reagieren und zudem das Optionsrecht vollständig unabhängig von der erwarteten Auswirkung auf Steuerzahlungen ausgeübt wird, wäre der zuvor ermittelte Aufkommenseffekt zu halbieren. Wird allerdings zusätzlich berücksichtigt, dass Unternehmen, für die eine Option zur Gruppenbesteuerung mit überdurchschnittlich großen steuerlichen Vorteilen verbunden wäre, eher das Wahlrecht in Anspruch nehmen, erscheint eine Erhöhung um weniger als 50\% sachgerechter. Wir unterstellen daher eine Minderung des Aufkommenseffekts um lediglich $25 \%$.

Zur Umrechnung in einen Jahreseffekt wird der ermittelte Gesamteffekt gleichmäßig auf vier Jahre verteilt. Dabei wird vernachlässigt, dass die Aufkommenswirkung aufgrund des Zusammenwirkens temporärer und endgültiger Aufkommenseffekte einer zeitlichen Struktur unterliegt (siehe Kapitel D.3.5.1). Wird der sich hieraus ergebende Jahreseffekt um die Aufkommensminderung erhöht, die sich infolge der Verrechnung finaler Verluste aus der Auflösung ausländischer Tochterkapitalgesellschaften einstellen kann, ergibt sich unter dem Strich ein erwarteter Jahreseffekt in einer Größenordnung von 2,15 bis 2,5 Milliarden $€$.

Diese Zahlen vernachlässigen zwar, dass eine umfassende Umsetzung des IFSt-Modells weitere Komponenten berücksichtigen könnte (Beispiele sind die Wiedereinführung der Mehrmütterorganschaft, weitergehende Erstreckung auf Unternehmen mit Auslandsbezug, Abschaffung von $\S 16 \mathrm{KStG})$. Während diese hier nicht berücksichtigten Komponenten jedoch keine Kernelemente des IFSt-Modells darstellen und daher zur Minimierung der Aufkommenseffekte aus der Einführung einer modernen Gruppenbesteuerung zunächst ggf. verzichtbar wären, wurden in den hier vorgenommenen Aufkommensberechnungen die grundlegenden Eckpfeiler des IFSt-Modells einbezogen. Die Berechnungen sollten deutlich machen, dass Aufkommensverluste, die mit einer entsprechenden Reform der Organschaft nach dem IFSt-Modell verbunden wären, im niedrigen einstelligen Milliardenbereich liegen dürften. 


\section{Mikrosimulationsmodell ASSERT}

\subsection{Modellansatz}

Zur Schätzung der relativen Aufkommenswirkungen, die bei einer Umsetzung des IFSt-Modells in geltendes Recht erwartet werden, wird ein Mikrosimulationsmodell eingesetzt, dessen Besonderheit darin besteht, dass die der Simulation zugrunde liegenden Daten prospektiv ermittelt werden.

Im Bereich der Unternehmensanalysen zeichnen sich die bisher bekannten Mikrosimulationsmodelle durch einen Vergangenheitsbezug aus, da sie die Simulation in aller Regel direkt auf den historischen Jahresabschlussdaten durchführen. Dieses Vorgehen hat zwar prinzipiell den Vorteil realistischer Annahmen in Bezug auf die Leistungsfähigkeit der betrachteten Unternehmen und schließt Schätzfehler aus, die aus einer zukunftsgerichteten Fortschreibung der Unternehmensentwicklung resultieren können. Andererseits basieren diese Ansätze auf der fragwürdigen Prämisse, dass die voraussichtlichen Effekte einer Steuerreform den Auswirkungen entsprechen, die sich eingestellt hätten, wäre die Steuerreform in der Vergangenheit umgesetzt worden. Zudem werfen rückwärtsgerichtete Ansätze die Frage auf, wie mit den finanziellen Folgen abweichender Besteuerungsregelungen umzugehen ist. Um diese Schwächen vergangenheitsbezogener Mikrosimulationsmodelle zu vermeiden, wurde mit ASSERT ein auf die Zukunft bezogener Ansatz entwickelt, in dem Fortschreibungstechniken zum Einsatz kommen, die eine den tatsächlichen Verhältnissen entsprechende Darstellung der zukünftigen Geschäftsentwicklung zum Ziel haben.

Zwar beruht auch ASSERT auf den Daten handelsrechtlicher Jahresabschlüsse. Für Zwecke der Mikrosimulation werden diese Daten jedoch in einem ersten Schritt in die Zukunft fortgeschrieben. Daneben bildet das Programm die Besteuerungsregeln für Unternehmen (sowohl in Deutschland als auch in weiteren Mitgliedstaaten der Europäischen Union) in seinen wesentlichen Merkmalen ab. In Bezug auf die Bemessungsgrundlage wird die handelsrechtliche Basis zum Beispiel um die Unterschiede zwischen handelsrechtlichen und steuerlichen Abschreibungen, der Besteuerung von Dividenden auf Ebene der Kapitalgesellschaften sowie der intertemporalen und konzerninternen Verlustverrechnung korrigiert. Vor diesem Hintergrund erfolgt die Ermittlung der Steuerzahlungen auf der Basis von Prognosen über die künftigen Jahresgewinne, die um eine Anpassung zur Abbildung der maßgebenden Steuervorschriften korrigiert werden. Daneben können die Konsequenzen für das Steueraufkommen bestimmt werden, die sich aus einer Änderung der steuerlichen Vorschriften ergeben („Steuerreform“). Noch nicht berücksichtigt 
werden kann, dass Steuerpflichtige infolge einer Reform steuerlicher Vorschriften ihr Verhalten ändern (vergleiche jedoch mit Bezug auf die Berechnungen für das IFSt-Modell Kapitel D.3.4.3 sowie Kapitel D.5). An diesem Punkt wird jedoch bereits gearbeitet.

\subsection{Ermittlung der Bemessungsgrundlage}

\subsubsection{Datenbasis}

Die Berechnungen in ASSERT beruhen auf den Jahresabschlussdaten, die durch den Datenbankanbieter Bureau van Dijk in der Datenbank Amadeus bereitgestellt werden. Die dort erfassten Unternehmen berichten ihre Daten allerdings nicht alle im erforderlichen Detail. Daher werden für Zwecke der Berechnungen alle Datensätze ausgeschlossen, die das für die Ermittlung der steuerlichen Bemessungsgrundlagen notwendige Mindestmaß an Datenverfügbarkeit und Datenabdeckung nicht erfüllen. Notwendige Informationen, die sich vor allem auch aus dem Simulationsansatz ergeben, betreffen die Struktur des Vermögens und der Schulden, den Gewinn oder Verlust vor Steuern, die Zins- und Dividendenerträge, außerordentliche Ergebnisbestandteile sowie den Bestand an vorgetragenen Verlusten. Um auf die mit einem Gruppenbesteuerungssystem einhergehenden steuerlichen Konsequenzen eingehen zu können, sind überdies Informationen über die Beteiligungsverhältnisse erforderlich. Von einer ausreichenden Verfügbarkeit der Daten für ein spezifisches Unternehmen wird ausgegangen, wenn die erforderlichen Parameter für mindestens drei aufeinanderfolgende Jahre berichtet werden.

\subsubsection{Operatives Ergebnis}

Der Algorithmus zur Bestimmung des operativen Ergebnisses beruht auf den Prognoseansätzen von Graham und Kim (2009) ${ }^{26}$ und Blouin, Core und Guay (2010). ${ }^{27}$ Erstere Autoren schlagen zur Prognose der Unternehmensentwicklung eine autoregressive Ermittlung der Unternehmensrendite vor. Hierbei wird unterstellt, dass die Rendite eines zukünftigen Geschäftsjahrs neben anderen Faktoren vor allem von der Realisation abhängt, die im jeweiligen Vorjahr erzielt wurde. Jennifer Blouin und ihre Koautoren gehen im Unterschied dazu von der Annahme aus, dass sich die beste Prognose für die zukünftige Entwicklung eines Unternehmens aus der durchschnittlichen Entwicklung vergleichbarer Unternehmen ergibt, die für diese Unternehmen in der Vergangenheit zu beobachten waren. Sie verwenden mithin keine Parameter, sondern stützen

\footnotetext{
${ }^{26}$ Graham und Kim (2009). Simulating Corporate Marginal Income Tax Rates and Implications for Corporate Debt Policy. Working Paper, Duke University.

${ }^{27}$ Blouin, Core und Guay (2010). Have the tax benefits of debt been overestated? J. Finan. Econ., 98, 195-213.
} 
sich auf die Entwicklung, die sie für einzelne Cluster untereinander vergleichbarer Unternehmen ermitteln und auf das jeweils fortzuschreibende Unternehmen anwenden. Frühere Studien zeigen, dass autoregressive Simulationsansätze vor allem bei der Fortschreibung von Renditekennzahlen eines einzelnen Unternehmens gute Ergebnisse erzielen, während parameterfreie Simulationsansätze nachweislich die beste Eignung aufweisen, wenn es um die Vorhersage einer Verteilung der Renditen über alle Unternehmen einer Stichprobe geht.

ASSERT bedient sich beider Verfahren. Da das Ziel dieses Mikrosimulationsmodells darin besteht, die Auswirkungen einer Steuerreform auf das Steueraufkommen zu schätzen, hat die zutreffende Verteilung des steuerpflichtigen Einkommens über alle Unternehmen jedoch höhere Relevanz als die zutreffende Vorhersage der voraussichtlichen Entwicklung einzelner Unternehmen. Daher wird für die Prognose der Investitionen, der Rendite des eingesetzten Kapitals („return on assets“), der Umsatzentwicklung, der Anzahl Mitarbeiter und des Personalaufwands grundsätzlich der parameterfreie Ansatz zugrunde gelegt. Grundlagen dafür bilden die Clustermediane der absoluten oder relativen Änderungen der oben genannten Größen. Dabei werden die Investitionen, Umsätze, Anzahl Beschäftigte und Personalaufwand unter Sicherheit fortgeschrieben, während die Rendite des eingesetzten Kapitals unter Unsicherheit mithilfe einer Monte-Carlo-Simulation und 50 Durchläufen ermittelt wird. Um darüber hinaus die konzeptionellen Vorteile der autoregressiven Simulationsmethode im Hinblick auf die Fortschreibung von Renditegrößen nicht gänzlich aufgeben zu müssen, wird der parameterfreie Ansatz bei der Fortschreibung von Renditegrößen mit dem Autoregressionsansatz kombiniert. Sind die Regressionsparameter entsprechender Autoregressionen signifikant, wird insoweit der Renditemittelwert beider Methoden verwendet. Im Hinblick auf die Investitionen, die Umsätze, die Beschäftigtenanzahl und die Personalaufwendungen wird aber ausschließlich der parameterfreie Simulationsansatz herangezogen. Beide Ansätze berücksichtigen darüber hinaus die Konjunkturentwicklung in Form der Entwicklung des Bruttoinlandsproduktes.

Für die Anwendung des parameterfreien Simulationsansatzes wurde in einem ersten Schritt die Gesamtheit der in der Stichprobe enthaltenen Unternehmen in mehrere, nach Ländern getrennte, gleich große Cluster aufgeteilt, so dass alle Unternehmen eines Clusters untereinander als vergleichbare Unternehmen angesehen werden können. Als Maßstab für die Vergleichbarkeit werden die Kapitalrendite und die Bilanzsumme der Unternehmen herangezogen. Daran anschlieBend werden in einem zweiten Schritt für jedes Cluster spezifische Clustervariablen ermittelt. Hierzu werden die für die Fortschreibung maßgebenden Unternehmenskennzahlen (maßgebend sind die Nettoinvestitionen in das Anlagevermögen, der Umsatz, die Beschäftigtenzahl, die Per- 
sonalaufwendungen und die Rentabilität des eingesetzten Kapitals, siehe oben) zu Kennzahlen für die Cluster verdichtet. Dabei werden beim Umsatz, der Beschäftigtenzahl, dem Personalaufwand und der Rentabilität des Kapitals die Mediane der relativen Änderung ermittelt, während in Bezug auf das Anlagevermögen der Median der Ausgaben für Nettoinvestitionen (die die Veränderung des Anlagevermögens direkt wiedergeben) ermittelt wird.

Für Zwecke der Fortschreibung werden die betroffenen Unternehmen in jedem Fortschreibungsjahr einem spezifischen Cluster zugeordnet. Grundlage dieser Zuordnung ist die Ähnlichkeit des Unternehmens mit den Unternehmen dieses Clusters im jeweiligen Vorjahr. Auf dieser Basis ergeben sich die fortgeschriebenen Werte durch Addition oder Multiplikation der für die Cluster ermittelten Mediane auf die jeweilige Vorjahresgröße.

Um den unterschiedlichen Abschreibungsdauern für den Firmenwert, Patente, Gebäude und Maschinen Rechnung zu tragen, werden die Struktur des Anlagevermögens und die hiermit verbundene Aufteilung der Nettoinvestitionen auf Gebäude, Maschinen, Patente und einen Firmenwert nach Maßgabe einer speziellen Aufteilungsregel festgelegt. In Bezug auf die im „sonstigen Anlagevermögen“ enthaltenen Finanzanlagen und das Umlaufvermögen wird unterstellt, dass Investitionen hierein proportional zu den Investitionen in das materielle und immaterielle Anlagevermögen erfolgen; eine Einschränkung gilt insoweit, als Änderungen im Finanzanlagebestand in voller Höhe auf Änderungen im Bestand an verzinslichen Wertpapieren zurückgeführt werden, während der Bestand an Beteiligungen an anderen Unternehmen über die Zeit konstant gehalten wird.

\subsubsection{Finanzergebnis}

Im Unterschied zum operativen Ergebnis werden die das Finanzergebnis bestimmenden Erträge und Aufwendungen direkt aus den Buchwerten der Finanzanlagen und finanziellen Verbindlichkeiten abgeleitet. Entsprechend erfolgt die Schätzung der Finanzaufwendungen durch Multiplikation der durchschnittlichen lang- und kurzfristigen Verbindlichkeiten des jeweiligen Jahres mit einem aus den Daten der Vergangenheit ermittelten unternehmensspezifischen Sollzinssatz.

Die Höhe der Verbindlichkeiten bestimmt sich dabei als Residualgröße zwischen Bilanzsumme und Eigenkapital, wobei das im Vorjahr bestehende Verhältnis der einzelnen Schuldposten zueinander beibehalten wird. Für die Berechnung des Eigenkapitals wird jeweils für Gewinn- und Verlustfälle aus den historischen Unternehmensdaten eine unternehmensspezifische Ausschüttungsquote ermittelt. Das Eigenkapital des Folgejahres ergibt sich insoweit aus dem Eigenkapital des Vorjahres zuzüglich des Ergebnisses nach Steuern abzüglich der Ausschüttung. 
Im Rahmen einer Bestimmung der Finanzerträge wird, in Übereinstimmung mit der Struktur der Finanzanlagen, zwischen Zinseinkommen, Gewinnen aus der Beteiligung an einer Personengesellschaft und Dividenden aus der Investition in Kapitalgesellschaften unterschieden. Auf dieser Basis wird die Höhe der Zinserträge aus dem Produkt von „Wert der Finanzanlagen abzüglich der Anteile an Tochtergesellschaften“ (nach dem Stand zum Ende des Vorjahres) und einem aus den Daten der Vergangenheit ermittelten unternehmensspezifischen Habenzinssatz ermittelt. Zur Berechnung des Betrags erhaltener Dividenden wird der prozentuale Anteil der Muttergesellschaft am Kapital der Tochtergesellschaft mit dem Betrag ausgeschütteter Dividenden multipliziert.

\subsubsection{Außerordentliches Ergebnis}

Das außerordentliche Ergebnis wird in einem zweistufigen Prozess ermittelt. Zunächst wird für jedes Unternehmen eine Zufallszahl gezogen, welche bestimmt, ob das betrachtete Unternehmen über ein außerordentliches Ergebnis verfügt oder nicht. In einem zweiten Schritt wird, ebenfalls mithilfe einer Zufallszahl, die Höhe des außerordentlichen Ergebnisses für das betrachtete Unternehmen ermittelt. Diese Schätzung beruht auf dem unternehmensspezifischen Mittelwert und der Standardabweichung des außerordentlichen Ergebnisses in der Vergangenheit, soweit diese von Null verschieden war.

\subsection{Ermittlung der Steuerzahlungen}

\subsubsection{Steuerzahlungen nach geltendem Recht}

Das zu versteuernde Einkommen wird in ASSERT nach folgendem Schema ermittelt:

Operatives Ergebnis vor Zinsen, Steuern und Abschreibungen

- Steuerliche Abschreibung

+ Finanzergebnis

+ Außerordentliches Ergebnis

- Steuerfreie Dividendeneinkünfte

+ Mögliche Einkommenszurechnung oder Ergebnisabführung infolge Gruppenbesteuerung

- Steuerliche Verlustverrechnung

$=\mathrm{Zu}$ versteuerndes Einkommen

Das operative Ergebnis vor Zinsen, Steuern und Abschreibungen (EBITDA) bestimmt sich aus dem Produkt von (prognostizierter) Rentabilität des eingesetzten Kapitals und Betriebskapital. Dieses Betriebskapital wird aus der Summe der Buchwerte aller Aktiva abzüglich der Finanzanlagen gewonnen. Erfasst wird der Mittelwert aus dem laufenden Jahr und dem jeweiligen Vorjahr. 
Art und Umfang der jährlichen steuerlichen Abschreibung abnutzbarer Gegenstände des Anlagevermögens richtet sich nach den landesspezifischen Abschreibungsregelungen in Bezug auf die Abschreibungsmethode (linear oder degressiv) und die unterstellte Nutzungsdauer. Hinsichtlich der steuerlichen Behandlung von bezogenen Dividenden gilt, dass technisch vereinfachend auch dann von einer Steuerfreistellung ausgegangen wird, wenn das Steuerrecht des betrachteten Staates eine Anrechnung der auf die Dividende entfallenden ausländischen Steuer vorsieht. In Bezug auf die Gruppenbesteuerung erfolgt in ASSERT sowohl eine Berücksichtigung nationaler als auch grenzüberschreitender Gruppenbesteuerungssysteme. Da entsprechende Daten fehlten, musste allerdings von einer Berücksichtigung der internationalen Gruppenbesteuerungssysteme Österreichs und Frankreichs abgesehen werden. Für Frankreich dürfte der sich hieraus möglicherweise ergebende Fehler schon deshalb nicht besonders groß sein, da die Fälle, in denen Verluste in Frankreich grenzüberschreitend verrechnet werden können, nur wenige Unternehmen erfassen sollte. Sieht ein Land die Möglichkeit einer Gruppenbesteuerung vor, wird unterstellt, dass alle Unternehmen, die die Voraussetzungen zur Inanspruchnahme der Gruppenbesteuerung erfüllen, auch tatsächlich für die Gruppenbesteuerung optieren.

Wie ein Blick in die deutsche Körperschaftsteuerstatistik des Jahres 2004 verdeutlicht, kommt den zu Beginn des Simulationszeitraums (Ende 2007) bestehenden steuerlichen Verlustvorträgen für die Genauigkeit der vorzunehmenden Aufkommensschätzungen eine wesentliche Bedeutung zu. Im Jahr 2004 belief sich der Gesamtbetrag der Einkünfte aller deutschen Unternehmen auf 106,23 Milliarden $€$; dem stand eine Nutzung von Verlustvorträgen aus Vorjahren in Höhe von 16,92 Milliarden € gegenüber. Soll die Simulation das Steueraufkommen nicht überschätzen, ist es erforderlich, dass eine mögliche Verrechnung von Verlusten berücksichtigt wird. Da die Datenbank Amadeus jedoch keine Angaben zur Höhe steuerlicher Verlustvorträge macht, ist der zu Beginn des Simulationszeitraums gegebene Bestand an steuerlichen Verlustvorträgen pro Unternehmen zu schätzen. Ausgangspunkt dieser Schätzungen sind die unternehmensspezifischen Jahresergebnisse für den Zeitraum ab dem Jahr 1994. Auf dieser Grundlage werden die in diesem Zeitraum erwirtschafteten Verluste in einer Nebenrechnung erfasst und unter Berücksichtigung der jeweils maßgebenden Vorschriften über die steuerliche Verlustverrechnung auf den Beginn des Prognosezeitraums fortentwickelt. Da keine weiteren Informationen zur Verfügung stehen, wird der zu Jahresbeginn 1994 bestehende Wert per Definition auf den Wert Null gesetzt. Dieses Verfahren führt grundsätzlich zu einer Unterschätzung der Verlustvorträge, da im Prinzip unterstellt wird, dass die Unternehmen der Stichprobe in 1994 keine Verlustvorträge ausgewiesen haben. Tatsächlich zeigt der Blick in die Körperschaftsteuerstatistik 2004, dass der verbleiben- 
de Verlustabzug unbeschränkt Körperschaftsteuerpflichtiger Ende 1994 bereits einen Betrag in Höhe von knapp 200 Milliarden $€$ erreicht hatte. Aus diesem Grund wurden die Verlustvorträge zur Analyse der Abhängigkeit der ermittelten Ergebnisse von der Höhe und Verteilung der körperschaftsteuerlichen Verlustvorträge auf Basis der Körperschaftsteuerstatistik 2004 so weit aufgestockt, dass sie dem Anteil entsprachen, mit der auch die Unternehmen in der Stichprobe erfasst sind. Bei dieser Analyse (Gliederungspunkt D.3.5.2) wurde deutlich, dass die Untererfassung der Verlustvorträge keinen maßgeblichen Einfluss auf die relative Änderung des Steueraufkommens durch die analysierten Steuerreformen hat.

Abschließend wird das zu versteuernde Einkommen mit dem jeweils geltenden tariflichen Steuersatz multipliziert, um die unternehmensspezifische Steuerzahlung zu ermitteln.

\subsubsection{Simulation von Steuerreformen}

Die modulare Struktur von ASSERT erlaubt ohne Weiteres sowohl die Abänderung aller erfassten Steuervorschriften als auch die Implementierung zusätzlicher (und vor allem auch neuer) Regelungen. Diese Änderung steuerlicher Vorschriften ist von den Investitionen und Gewinnen der Fortschreibungsperioden grundsätzlich unabhängig, hat aber Liquiditätswirkungen und kann auch das erfasste Verhalten der Steuerpflichtigen in Bezug auf ihre Investitions- oder Finanzierungsentscheidung beeinflussen. Unabhängig davon braucht aber für Zwecke der Simulation einer Steuerreform lediglich der Teil des Modells angepasst werden, der die fortgeschriebenen Gewinne in Steuerzahlungen umrechnet. Insoweit aus einer Steuerreform abweichende Steuerzahlungen resultieren, berücksichtigt ASSERT die einsetzenden Liquiditätswirkungen durch eine Anpassung der Kapitalstruktur bei den betroffenen Unternehmen. Dabei führen höhere Steuerzahlungen im Modell zu reduzierten Ausschüttungen; zudem wird der aus der zusätzlichen Steuerzahlung resultierende Liquiditätsrückgang durch die Aufnahme neuen Fremdkapitals ausgeglichen.

\subsection{Ermittlung des Steueraufkommens}

Das Steueraufkommen wird als Summe der Steuerzahlungen aller Unternehmen auf Bruttobasis ermittelt. Am Ende der Simulationsperiode bestehende Verlustvorträge werden in der Aufkommensgröße nicht direkt berücksichtigt. Wird die Simulation einer Steuerreform auf Basis von Jahresabschlussdaten der Datenbank Amadeus durchgeführt, resultiert in Bezug auf die Prognose des Steueraufkommens das Problem, dass Amadeus zwar weitgehend alle deutschen Unternehmen enthält, für die Mehrheit dieser Unternehmen aber lediglich deren Bilanzsummen berichtet werden. Hieraus ergäbe sich kein größeres Problem, wenn sichergestellt wäre, dass die 
Unternehmen, für die Daten berichtet werden, eine repräsentative Stichprobe aller steuerpflichtigen Körperschaften bilden. Tatsache ist aber, dass die dargestellten Mindestanforderungen, die in Bezug auf den Simulationsalgorithmus zu erfüllen sind, von primär großen Unternehmen erfüllt werden. Um die Fehler, die aus dieser Mindererfassung kleiner und mittelgroßer Unternehmen resultieren können, für die Prognose des Gesamtsteueraufkommens möglichst klein zu halten, werden die bestehenden Ungleichgewichte im Rahmen der Hochrechnung ausgeglichen.

Hierzu werden die Unternehmen nach Maßgabe der Parameter „Ansässigkeitsstaat", „Größe“ und „Konzernzugehörigkeit“ in Gruppen eingeteilt. Sodann werden die Anzahl Unternehmen der Stichprobe an die Verteilung der Grundgesamtheit angepasst und die ermittelten Steuerzahlungen nach dem Verhältnis der Bilanzsummen (Bilanzsumme der Stichprobenunternehmen zur Bilanzsumme aller Unternehmen, über die in AmADEus berichtet wird) auf die Gesamtsteuerzahlungen und das Steueraufkommen hochgerechnet.

Ein weiteres Problem besteht darin, dass in der AmADEus-Datenbank die Verlustunternehmen untererfasst sind. Da eine Vernachlässigung dieses Umstands zu einer Überschätzung des Steueraufkommens führen würde, wird aus der Körperschaftsteuerstatistik zudem ein das Verhältnis von Gewinn- zu Verlustunternehmen wahrender Hochrechnungsfaktor abgeleitet, um den der zuvor ermittelte Hochrechnungsfaktor korrigiert wird.

\subsection{Evaluierung der Modellgüte}

\subsubsection{Prognosegüte der durch Fortschreibung ermittelten Werte}

Um die Prognosegenauigkeit der Fortschreibungen durch ASSERT zu evaluieren, wurden die Mittelwerte, Mediane und Standardabweichungen der mit Hilfe des Programms ermittelten Fortschreibungswerte mit den tatsächlichen Realisationen verglichen, die diese Unternehmen in den Jahren 2008 bis 2010 erzielt haben. Geprüft wurden die Prognosegüte des operativen Ergebnisses (EBITDA), der Abschreibungen, des Finanzergebnisses und des außerordentlichen Ergebnisses. Im Einzelnen ergaben sich dabei folgende Resultate (hierbei sind die absoluten Werte in T EUR angegeben).

Diese Vergleiche zeigen, dass die Prognosegüte der mit Hilfe von ASSERT ermittelten Werte insgesamt sehr zufriedenstellend ist. Die statistischen Maßgrößen (Mittelwert, Median und Standardabweichung) liegen in allen Fällen ausreichend nahe beieinander, zumal auf eine Korrektur um Ausreißer (siehe die im Vergleich zu den Medianen hohen Mittelwerte) verzichtet wurde. Die Korrelationen zwischen den prognostizierten und realisierten Werten in Bezug auf das operative 
Tabelle D.14: Prognosegüte von ASSERT

\begin{tabular}{llrrr}
\hline Operatives Ergebnis & 2008 & 2009 & 2010 \\
\hline \multirow{2}{*}{ ASSERT } & Mittelwert & 8.031 & 6.761 & 13.533 \\
& Median & 1.212 & 890 & 1.052 \\
& Standardabweichung & 48.216 & 48.709 & 103.596 \\
\multirow{2}{*}{ AMADEUS } & Mittelwert & 7.647 & 6.872 & 12.627 \\
& Median & 1.232 & 953 & 1.123 \\
& Standardabweichung & 47.475 & 47.552 & 74.074 \\
\hline Vergleich & Korrelation & 0,7401 & 0,6357 & 0,6644 \\
\hline
\end{tabular}

\begin{tabular}{llrrr}
\hline Abschreibungen & 2008 & 2009 & 2010 \\
\hline \multirow{2}{*}{ ASSERT } & Mittelwert & 3.399 & 2.987 & 5.542 \\
& Median & 382 & 335 & 273 \\
& Standardabweichung & 13.335 & 20.495 & 44.817 \\
\multirow{3}{*}{ AMADEUS } & Mittelwert & 3.394 & 3.135 & 5.179 \\
& Median & 370 & 363 & 310 \\
& Standardabweichung & 21.599 & 20.265 & 42.745 \\
\hline Vergleich & Korrelation & 0,9854 & 0,9673 & 0,9919 \\
\hline
\end{tabular}

\begin{tabular}{llrrr}
\hline Ergebnis der & ordentlichen Geschäftstätigkeit & 2008 & 2009 & 2010 \\
\hline \multirow{2}{*}{ ASSERT } & Mittelwert & 4.401 & 3.890 & 8.233 \\
& Median & 454 & 345 & 492 \\
& Standardabweichung & 43.474 & 44.107 & 87.404 \\
\multirow{2}{*}{ AMADEUS } & Mittelwert & 4.467 & 3.426 & 6.693 \\
& Median & 532 & 352 & 502 \\
& Standardabweichung & 41.000 & 29.667 & 37.335 \\
\hline Vergleich & Korrelation & 0,5225 & 0,3453 & 0,4630 \\
\hline
\end{tabular}

Ergebnis liegen bei circa 70\%, während sie bei den Abschreibungen im Durchschnitt mehr als 98\% erreichen und beim Ergebnis der gewöhnlichen Geschäftstätigkeit knapp $45 \%$ betragen. Im letzteren Fall wirken sich die Abweichungen aufgrund der absolut geringeren Werte in der Korrelation stärker aus.

\subsubsection{Vergleich von ermittelten und tatsächlichen Verlustvorträgen}

Ein Abgleich des Bestands an steuerlichen Verlustvorträgen in der Stichprobe mit den Verlustvorträgen nach Körperschaftsteuerstatistik weist darauf hin, dass der Bestand an Verlustvorträgen für die Jahre 1994 bis 2007 untererfasst ist, wobei der Erfassungsgrad im Zeitablauf zunimmt (die Untererfassung zurückgeht). Mit dem Umstand, dass in ASSERT nur eine Auswahl 
von Kapitalgesellschaften Eingang findet, lässt sich die Unterrepräsentierung nicht vollständig erklären, da 13,46\% (14,61\%) der kumulierten Gewinne und Verluste in 2006 (2007) erfasst werden, während der Erfassungsgrad bei den Verlustvorträgen nur etwa ein Drittel dieses Anteils beträgt. Die Diskrepanz beruht ganz wesentlich auf der bereits oben dargestellten Datenlücke in Bezug auf die vor 1994 aufgelaufenen Verlustvorträge. Die Auswirkungen dieser Datenlücke auf die Berechnungsergebnisse für das IFSt-Modell wurden im Rahmen einer Alternativrechnung geprüft (vergleiche Kapitel D.3.5.2). Daneben zeichneten sich deutsche Kapitalgesellschaften noch zu Beginn dieses Jahrhunderts durch eine eher konservative Informationspolitik aus, die dazu führte, dass die Anzahl deutscher Unternehmen in AMADEus relativ klein ist.

Vergleicht man den mithilfe von ASSERT für die Jahre 2004 bis 2007 ermittelten Bestand an steuerlichen Verlustvorträgen mit den Zuwächsen, die in der Körperschaftsteuerstatistik berichtet werden, zeigt sich, dass ASSERT knapp 14\% der tatsächlichen Zuwächse erfasst. Dies steht im Einklang mit dem oben angesprochenen Erfassungsgrad kumulierter Gewinne und Verluste. Daher lässt sich vermuten, dass die Entwicklung der Verlustvorträge im Zeitablauf, vor allem aber in Bezug auf die jüngere Vergangenheit, korrekt geschätzt wird. Abbildung 1 stellt die Entwicklung der Verlustvorträge im Zeitablauf laut Körperschaftsteuerstatistik und ASSERT einander vergleichend gegenüber. Dabei werden für ASSERT sowohl die hochgerechneten (Hochrechnung 1) als auch die nicht hochgerechneten Verlustvorträge dargestellt. Der Vergleich zeigt, dass ein hoher Bestand an Verlustvorträgen auf nicht in AMADEus enthaltene Unternehmen entfällt. Mögliche Gründe sind, dass diese Verlustvorträge auf öffentliche oder nicht mehr aktive Unternehmen entfallen.

Abbildung D.1: Vergleich der Verlustvorträge aus ASSERT und Körperschaftsteuerstatistik

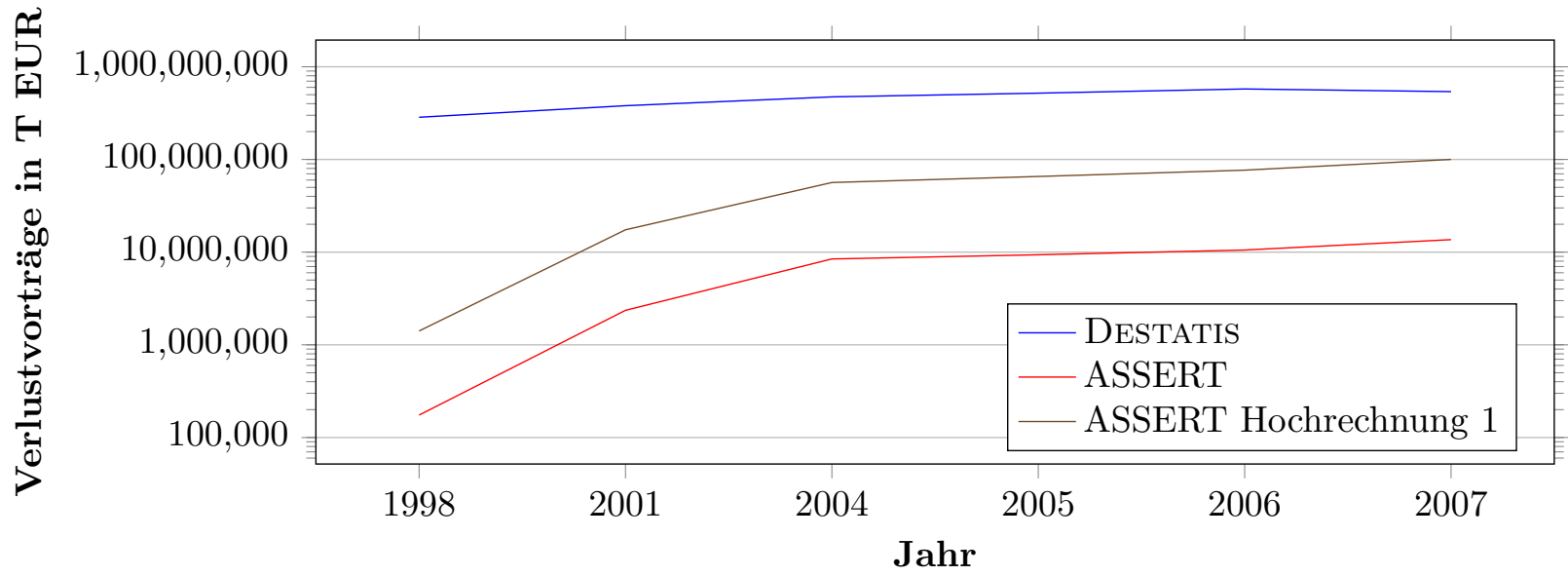




\subsubsection{Vergleich von ermitteltem und tatsächlichem Körperschaftsteueraufkommen}

Ziel des Mikrosimulationsmodells ASSERT ist die Quantifizierung relativer Aufkommensänderungen durch Steuerreformen; das Simulationsmodell ist demzufolge nicht darauf ausgerichtet, das Steueraufkommen als absolute Größe vorherzusagen. Bei der Vorhersage relativer Aufkommensänderungen kommt der Zusammensetzung der Stichprobe eine erhebliche Bedeutung zu. Ist die Stichprobe nicht verzerrt, kann davon ausgegangen werden, dass die relative Änderung des Steueraufkommens hinreichend genau quantifiziert werden kann, unabhängig davon, ob die absolute Höhe des simulierten Aufkommens mit der Höhe des tatsächlichen Aufkommens übereinstimmt.

Um die Güte der simulierten Aufkommenswirkungen zu testen, wurde das in ASSERT ermittelte Körperschaftsteueraufkommen den Körperschaftsteuereinnahmen laut Bundesministerium der Finanzen gegenübergestellt. Abbildung 2 zeigt die mithilfe von ASSERT (bei anschließender Hochrechnung) ermittelten Körperschaftsteueraufkommen der Jahre 2008 bis 2011 und die Körperschaftsteuereinnahmen nach den Berechnungen des Bundesministeriums der Finanzen für die Jahre 2008 bis 2011. Es wird deutlich, dass die Entwicklung des Steueraufkommens, mit Ausnahme des Jahres 2011, insgesamt treffend prognostiziert wird.

Abbildung D.2: Vergleich des Körperschaftsteueraufkommens nach ASSERT und Bundesministerium der Finanzen (auf Basis der bereinigten Kasseneinnahmen)

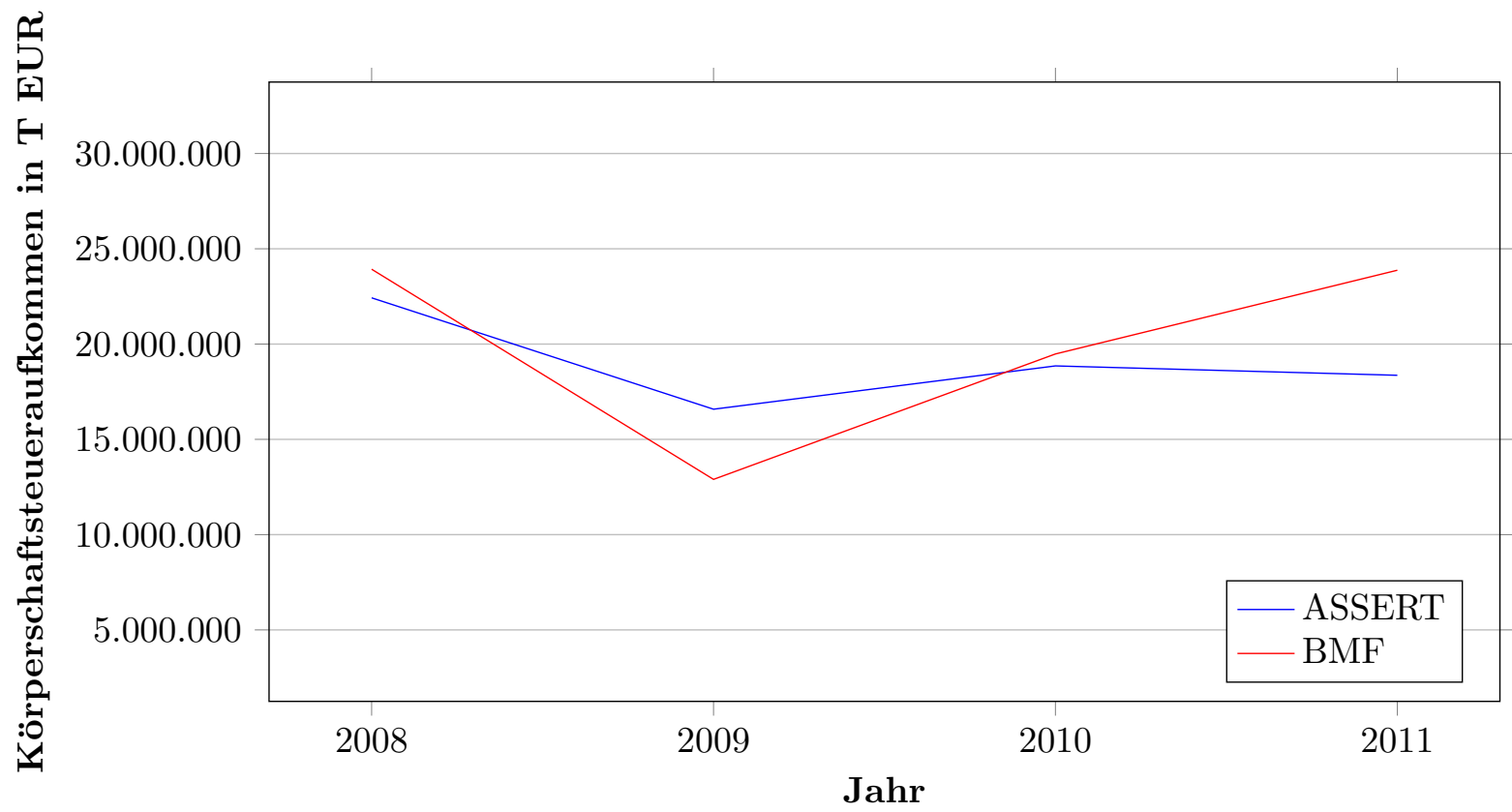




\section{Anhang - Reformvorschlag des Instituts Finanzen und Steuern}

Tabelle D.15: Überblick über die einzelnen Elemente des Reformvorschlags

1. Die Voraussetzung des Gewinnabführungsvertrags für die Gruppenbesteuerung wird aufgehoben.

2. Mit der Abschaffung des Gewinnabführungsvertrags als Voraussetzung der Gruppenbesteuerung gewinnt der Gedanke der wirtschaftlichen Einheit des Konzerns (wieder) an Bedeutung. Verluste der Gruppengesellschaften führen zu einer wirtschaftlichen Belastung beim Gruppenträger. Dies ist eine steuersystematisch tragfähige Begründung für die Verlustzurechnung.

3. Die bewährte Technik der steuerlichen Ergebniszurechnung zur Obergesellschaft (Gruppenträger) wird beibehalten und weder durch eine Vollkonsolidierung noch durch eine wahlweise Verlustübertragung zwischen Gruppengesellschaften ersetzt.

4. Die Rechtsform der als Gruppenträger und Gruppengesellschaften geeigneten Gesellschaften orientiert sich am gegenwärtigen Stand. Gruppenträger kann jedes bilanzierende gewerbliche Unternehmen sein, d.h. auch Personengesellschaften und natürliche Personen. Als Gruppengesellschaften kommen lediglich Kapitalgesellschaften in Betracht.

5. Voraussetzungen und Rechtsfolgen der Gruppenbesteuerung bleiben für Körperschaftsteuer und Gewerbesteuer einheitlich geregelt. Bei entsprechender Rechtsform des Gruppenträgers wirkt sich die Gruppenbesteuerung weiterhin auch in der Einkommensteuer aus.

6. Ausgehend von der wirtschaftlichen Einheit des Konzerns kann es, insbesondere wenn zugleich die Anforderungen an die Beteiligungsquote angehoben werden (dazu These Nr. 7), bei einer unbegrenzten sofortigen Zurechnung des Verlusts der Gruppengesellschaft zum Gruppenträger bleiben.

Sollte es indessen - entgegen der hier präferierten Lösung - als erforderlich angesehen werden, dem Gedanken der Verlusttragung stärker Rechnung zu tragen, kann dies durch eine Begrenzung der Verlustzurechnung auf den Betrag des Investments des Gruppenträgers erreicht werden. Dieser drückt sich im steuerlichen Beteiligungsbuchwert einschließlich „nachlaufender" Einlagen aus.

Will man die durch den Investmentgedanken begründete und mit einigen technischen Schwierigkeiten verbundene betragsmäßige Begrenzung der Verlustzurechnung vermeiden, kann ergänzend eine weitergehende zivilrechtlich begründete Haftung des Gruppenträgers für Verluste bzw. Verbindlichkeiten des Gruppenmitglieds als Grundlage für eine unbeschränkte Verlustzurechnung herangezogen werden. Die weitergehende Haftung kann z.B. durch aktienrechtliche Eingliederung oder durch harte Patronatserklärungen herbeigeführt werden. Gleichsam im Sinne einer Übergangsregelung könnte insoweit auch der Abschluss eines Gewinnabführungs- oder Beherrschungsvertrags als ausreichend angesehen werden. Dies würde insbesondere den Bedürfnissen der Unternehmen Rechnung tragen, in der Vergangenheit abgeschlossene Gewinnabführungsverträge nach Umstellung auf das neue Recht weiterlaufen zu lassen.

Hingewiesen sei, dass jede Begrenzung der Verlustzurechnung - sei es betragsmäßig durch die Höhe des Investments, sei es durch die Forderung zusätzlicher zivilrechtlicher Verlustübernahmevereinbarungen - unweigerlich die Komplexität der Gruppenbesteuerung erhöht und die Chancen einer Entkoppelung vom Gesellschaftsrecht reduziert. 
7. Die Mindestbeteiligungsquote des Gruppenträgers an der Gruppengesellschaft wird von der einfachen Stimmrechtsmehrheit auf eine qualifizierte Mehrheit i.H.v. 75 \% (am Nennkapital und an den Stimmen) angehoben, um dem zur Begründung einer unbegrenzten Verlustzurechnung herangezogenen Gedanken der wirtschaftlichen Einheit des Konzerns stärker Rechnung zu tragen. Anerkannt wird im Hinblick auf bestehende Konzernstrukturen trotz der hiermit verbundenen Komplexität weiterhin auch eine mittelbare Eingliederung.

8. Die Wiedereinführung der Mehrmüttergruppenbesteuerung ist aus steuersystematischen Gründen nicht geboten, auch wenn sie wirtschaftspolitisch wünschenswert wäre.

9. Die Gruppenbesteuerung setzt einen gemeinsamen Antrag von Gruppenträger und Gruppengesellschaft mit grundsätzlich fünfjähriger Bindung voraus. Gesellschaftsrechtlich wird davon ausgegangen, dass es sich dabei um eine Geschäftsführungsmaßnahme handelt.

10. Weitergehender Voraussetzungen bedarf es nicht. Insbesondere sollte der Abschluss eines Steuerumlagevertrags nicht zur Voraussetzung der Gruppenbesteuerung gemacht werden. Steuerumlageverträge regeln die gesellschaftsrechtlichen Folgen der Gruppenbesteuerung, sind aber keine Voraussetzung für diese. Zur Vermeidung gesellschaftsrechtlicher Konflikte sollte die Verpflichtung zur Abrechnung von Steuerumlagen auf Stand-alone-Basis allerdings nach klaren Regeln im Gesellschaftsrecht vorgegeben werden.

11. Die Ermittlung des zuzurechnenden steuerlichen Ergebnisses orientiert sich an der heutigen Rechtslage. Einkommen und Gewerbeertrag der Gruppengesellschaft werden wie bei jeder anderen Kapitalgesellschaft zunächst selbständig ermittelt, allerdings mit den in $\S 15$ KStG und R 7.1 (5) GewStR geregelten Besonderheiten. Auf die derzeit in $\S 16$ KStG vorgesehene Versteuerung von Ausgleichzahlungen an Minderheitsgesellschafter könnte zukünftig verzichtet werden.

12. Vor Begründung der Gruppe entstandene Verluste der Tochtergesellschaft sollten nicht länger „eingefroren“, sondern zur Verrechnung mit in der Gruppenzeit erwirtschafteten Gewinnen der Tochtergesellschaft zugelassen werden. Abzulehnen sind in die entgegengesetzte Richtung gehende Überlegungen, zwecks Gegenfinanzierung die Verrechnung von Vorgruppenverlusten gegenüber der heutigen Rechtslage weiter einzuschränken und steuerliche Verluste, die vor Eintritt in die Gruppe aufgelaufen sind, generell nur noch bei dem jeweiligen Gruppenmitglied zur Verrechnung zuzulassen. Gruppenträgerverluste aus Vorgruppenzeit müssen in jedem Fall weiterhin unbegrenzt mit innerorganschaftlichen Gewinnen der gesamten Gruppe verrechnet werden können.

13. Der Ergebnistransfer von der Gruppengesellschaft an den Gruppenträger während der Phase der Gruppenbesteuerung muss grundsätzlich weiter ertragsteuerneutral erfolgen. Die Abgrenzung zum Transfer von Vorgruppengewinnen wird durch ein Konzept von Gruppengesellschafts- und Gruppenträgerkonten gewährleistet. Diese im Vergleich zum heutigen Ausgleichspostenregime einfache Technik macht zukünftig $§ 14$ Abs. 3 KStG entbehrlich. Hierzu müssen sowohl auf Gruppengesellschafts- als auch auf Gruppenträgerebene Konten geführt werden. Im Gruppengesellschaftskonto werden in der Gruppenzeit bei der Gruppengesellschaft erzielte steuerbilanzielle Ergebnisse festgehalten und vorrangig gegenüber dem zum Zeitpunkt des Eintritts in die Gruppe gegebenen ausschüttbaren Gewinn ausgekehrt. Ausschüttungen, die das Gruppengesellschaftskonto übersteigen, werden nach den allgemeinen Regeln behandelt. Das vom Gruppenträger zu führende Gruppenträgerkonto ist ein Unterkonto zum Buchwert der Beteiligung des Gruppenträgers an der Gruppengesellschaft, in dem die in der Gruppenzeit bei der Gruppengesellschaft erzielten steuerbilanziellen Ergebnisse gespiegelt und Ausschüttun- 
gen von in der Gruppenzeit erzielten Gewinnen verrechnet werden. Vermieden werden kann mit dem Konzept des Gruppengesellschafts- und Gruppenträgerkontos auch die im heutigen Ausgleichspostensystem bestehende Möglichkeit (temporär) steuerfreier Vollausschüttung.

Sollte - entgegen der hier präferierten Lösung - dem Gedanken der Verlusttragung in Form der Begrenzung der Verlustzurechnung auf den Betrag des Investments des Gruppenträgers Rechnung getragen werden, ließe sich dies technisch durch Bezugnahme auf Beteiligungsbuchwert und Gruppenträgerkonto abbilden.

14. Eine echte grenzüberschreitende Gruppenbesteuerung ist nicht vorgesehen, weil abgesehen von den Aufkommenseffekten die aus einem damit verbundenen Übergang auf die Anrechnungsmethode resultierenden Fragestellungen nicht beherrschbar erscheinen. Europarechtlich besteht keine Verpflichtung zu einer vollständigen Gleichbehandlung von Inlandskonzernen und grenzüberschreitenden Konzernen. Eine europaweite Konzernbesteuerung kann ohnehin nur unter Beteiligung aller Mitgliedstaaten im Rahmen einer GKKB Richtlinie verwirklicht werden.

15. Der Inlandsbezug beim Gruppenträger wird etwas weitergehend als bisher in dem Sinne geregelt, dass es grundsätzlich ausreicht, wenn entweder der Sitz oder der Ort der Geschäftsleitung des Gruppenträgers im Inland belegen ist. Doppelansässige Gesellschaften mit Geschäftsleitung im Ausland können aber ebenso wie nichtansässige Gesellschaften nur insoweit Organträger sein, als die Beteiligung an der Gruppengesellschaft zu einer inländischen Betriebsstätte gehört. Eine Zweigniederlassung, wie bisher in $\S 18 \mathrm{KStG}$ geregelt, ist nicht notwendig.

16. Für die Fälle, in denen aus Gründen des DBA-Diskriminierungsverbots, aus europarechtlichen oder aus anderen Gründen eine Einkommens- oder Gewerbeertragszurechnung zu einem ausländischen oder doppelansässigen Gruppenträger ohne Zuordnung zu einer inländischen Betriebsstätte als rechtlich geboten angesehen werden sollte, bedarf es der gesetzlichen Fiktion einer inländischen Betriebsstätte des ausländischen Gruppenträgers, der Einkommen und Gewerbeertrag und die Anteile an der Gruppengesellschaft zugerechnet werden. Eine derartige Regelung würde entgegenstehende DBA überwinden.

17. Als Gruppengesellschaft werden nicht nur Kapitalgesellschaften mit Sitz und Ort der Geschäftsleitung im Inland anerkannt, sondern auch ausländische Kapitalgesellschaften mit inländischem Ort der Geschäftsleitung. EU-/EWR-Gesellschaften mit Sitz im Inland, aber ohne inländischen Ort der Geschäftsleitung können mit ihren inländischen Betriebsstätten in die Gruppenbesteuerung einbezogen werden.

18. Die uneingeschränkte Zurechnung von Verlusten aus Auslandstochterkapitalgesellschaften mit Nachversteuerung, wie sie in Österreich praktiziert wird, wäre zwar aus wirtschafts- und europapolitischer Sicht wünschenswert, ist allerdings praktisch schwer umsetzbar und wegen unwägbarer Haushaltswirkungen wenig realistisch. Gesetzlich geregelt werden sollte aber die Berücksichtigung „echter“ finaler Verluste von in EU/EWR-ansässigen Auslandsgesellschaften, da deren Berücksichtigung, sofern diese Gesellschaften die Voraussetzungen der Gruppenbesteuerung erfüllen, europarechtlich geboten ist.

19. Die Haftungsnorm des $\S 73 \mathrm{AO}$ ist verursachungsgerecht dahingehend zu begrenzen, dass die Gruppengesellschaft für Steuerschulden der Gruppe nur insoweit haftet, als sie zum Ergebnis beigetragen hat.

20. Verfahrensrechtlich ist eine Verknüpfung der Steuerbescheide auf Gruppengesellschaftsund Gruppenträgerebene im Sinne von Grundlagen- und Folgebescheid vorzusehen. 


\title{
E The effects of tax depreciation on the level of investment - an empirical analysis
}

\begin{abstract}
${ }^{*}$
Investments are of crucial importance for economic growth and employment, and the possible determinants of investment behavior are manifold. In theory, enhanced tax depreciation regulations stimulate investment because of the impact of such regulations on the cost of capital. Empirical analyses in this field are mainly limited to publicly owned companies in the United States, and the results of these analyses vary. Against the background of an increasing importance of small and medium-sized corporations for both the economy and society, the impact of tax incentives on such companies is of particular interest. Using a panel dataset for publicly and privately owned European corporations from nine different countries, this paper investigates the impact of tax depreciation on the level of investment. I apply a pooled ordinary least squares approach to determine the effects of tax depreciation on investment in the cross-section. The effects of tax depreciation on investment over time are analyzed using panel data models that include country or firm fixed effects, respectively. In this regard, tax depreciation regulations for buildings, machinery and patents are considered across countries and over time based on the present values of depreciation allowances. I find a positive association between the present value of depreciation allowances for machinery and investment activity, both in the cross-section and over time. This relation is most strongly pronounced for small companies and only holds for companies that are likely to pay taxes.
\end{abstract}

\footnotetext{
*I thank Andreas Oestreicher, Robert Schwager, Reinald Koch and participants of the Finance, Accounting, and Taxes research seminar in Göttingen; Joachim Gassen, Wayne Landsman, Cathy Shakespeare and participants of the 2012 EAA Doctoral Colloquium in Bled; Martin Jacob, Michael Overesch and participants of the 2012 $2^{\text {nd }}$ Workshop on Current Research in Taxation in Münster; Ed Maydew; four anonymous referees; participants of the 2013 EAA Annual Conference in Paris; Sebastian Eichfelder and participants of the 75. Jahrestagung der Hochschullehrer für Betriebswirtschaft e.V. 2013 in Würzburg for their helpful comments. The usual disclaimer applies.
} 


\section{Motivation}

Investments are of crucial importance for economic growth and employment. In addition to their direct impact on growth and employment, investments may generate learning externalities (i. e., companies may learn from other companies' successful or unsuccessful investments) and may be the mechanism through which innovations stimulate economic growth (Chirinko, 1993). Against this background, it is unsurprising that "the explanation of firms investment behavior is one of the central issues in empirical economics" (Behr, 2003). In light of the global economic and financial crisis that led to weakened economic growth in countries all over the world, mechanisms that stimulate investment and thus economic growth have become increasingly important.

The theoretically possible determinants of investment behavior are manifold. According to Neoclassical Theory, a company aims to maximize its market value, i. e., its discounted flow of future profits (Hall \& Jorgenson, 1967; for details, see Section E.3). In this context, the desired (optimal) stock of capital is defined as the value of output that is discounted by the user cost of capital (Chirinko, 1993). Consequently, investments are negatively dependent on the cost of capital, which, in turn, depends (among other things) on both the tax rate and the discounted value of depreciation allowances. Whereas an increasing tax rate generally increases the cost of capital and thus decreases the incentive to invest, depreciation allowances have a positive impact on the investment incentive. Because the discounted value of depreciation allowances increases with less restrictive depreciation regulations (which is the case if, for example, the useful life for tax purposes is reduced), one would expect higher investments in response to relaxed regulations for tax depreciation.

This relation has also been used by policy makers seeking to stimulate investment. In 2002 and 2003, the Bush administration increased depreciation allowances for equipment investments through the Job Creation and Worker Assistance Act of $2002^{1}$ and the Jobs and Growth Tax Relief Reconciliation Act of $2003^{2}$ to encourage investment (Desai \& Goolsbee, 2004). Furthermore, the German government increased depreciation allowances in 2006 and 2007 to stimulate investment activity (see BT-Drucks. 16/643). A study on behalf of the German Federal Ministry of Finance on the evaluation of depreciation practices (Oestreicher \& Spengel, 2002) further emphasizes the importance of depreciation provisions to policy makers.

In addition, the relevance of tax depreciation rules is particularly apparent when examining the

\footnotetext{
${ }^{1}$ URL: http://www.gpo.gov/fdsys/pkg/PLAW-107publ147/html/PLAW-107publ147.htm, last access: July 9, 2013.

${ }^{2}$ URL: http://www.gpo.gov/fdsys/pkg/PLAW-108publ27/html/PLAW-108publ27.htm, last access: July 9, 2013.
} 
current discussion regarding the introduction of a Common Consolidated Corporate Tax Base in the European Union. To overcome distortions resulting from 28 different tax systems within the European Union, the European Commission is currently developing an approach to determine taxable income that uses common tax bases within the European Union, consolidates these tax bases and apportions the consolidated tax bases to the relevant member states (see European Commission, $\operatorname{COM}(2011)$ 121/4). Because a common tax base in Europe requires, inter alia, uniform regulations with regard to depreciation, the impact of these regulations on investment is extremely relevant. The relevance is particularly apparent in studies assessing the impacts of a Common Consolidated Corporate Tax Base. For example, the European Commission, 2011, finds that this reform proposal would, on average, cause broader tax bases to be mainly attributable to the depreciation provisions that are applied. Against this background, extending our knowledge of the impact of these provisions on investment is even more important.

Although there is a large body of theoretical literature on the effects of taxation on investment (for an overview, see Chirinko, 1993), the empirical results of these studies vary (for a detailed overview of relevant empirical studies, see Section E.2) and, at least with regard to depreciation effects and effects of tax incentives in general, such results are mainly based on data from public companies in the United States. In the present paper, I aim to provide evidence of the impact of tax depreciation provisions on investment in the European Union with regard to companies that are not necessarily publicly listed. Applying a pooled cross-section and a panel data approach, the effect of depreciation regulations on the level of investment is examined both across countries and over time. In addition, I analyze whether companies react to changes in depreciation regulations differently depending on their size. In this respect, tax depreciation regulations are considered country- and year-specifically by way of the present values of depreciation allowances for buildings, machinery and patents. I find a significantly positive association between the present value of depreciation allowances for machinery and investment activity, both in the cross-section and over time. This relation is most strongly pronounced for small companies and holds only for companies that are likely to pay taxes. A similar effect can also be found for the tax depreciation of patents. However, as will be discussed below, this effect is not necessarily caused by investment activity. I do not find any clear evidence with regard to an impact of tax depreciation of buildings on investment. The results are of crucial importance for policy makers aiming to stimulate investment activity, in particular against the background of the global economic and financial crisis and the current discussions concerning the implementation of a Common Consolidated Corporate Tax Base. 
In view of the above discussion, this analysis primarily contributes to existing research in three ways. First, the data employed originate from nine countries within Europe, whereas previous studies have largely been based on data from companies in the United States. Second, and more important, using data of private and public companies of different sizes rather than only data of stock-oriented companies, it is possible to examine size-specific investment effects of tax incentives. This is particularly important when looking at the structure of businesses in the European Union. In 2012, approximately 20.7 million small and medium-sized companies represented more than 98 percent of all businesses in the European Union, constituted 58 percent of gross value added and accounted for 67 percent of total employment (Wymenga et al., 2012). According to the European Commission these companies are a "key driver for economic growth, innovation, employment and social integration". ${ }^{3}$ Third, the study places a stronger focus on the general impact of tax depreciation regulations on the level of investment rather than on the effects of a particular reform.

The remainder of the paper proceeds as follows: In Section E.2, I provide an overview of empirical literature dealing with the impacts of tax depreciation on investments. Section E.3 describes the theoretical framework of the analysis by briefly reviewing Neoclassical Theory and, based on this theory, derives the theoretical impact of both the tax rate and tax depreciation on investment activity. In Section E.4, the research design is outlined, followed by a description of the sample selection process and relevant descriptive statistics in Section E.5. Results are presented and discussed in Section E.6; Section E.7 concludes the paper.

\section{Prior literature}

There is a large body of both theoretical (for an overview, see Chirinko, 1993) and empirical (overviews of empirical studies on the impact of tax parameters on business investment can be found in Hassett \& Hubbard, 2002, Hassett \& Newmark, 2008 and Hanlon \& Heitzman, 2010) literature on the effects of tax parameters on business investment. Early empirical studies have analyzed the impact of tax parameters on investment on an aggregated basis. ${ }^{4}$ This research incorporates several problems. For example, endogeneity may exist in cases in which a government reduces tax rates in response to observed declines in aggregate investment. Other problematic

\footnotetext{
${ }^{3}$ URL: http://ec.europa.eu/enterprise/policies/sme/index_en.htm, last access: July 2, 2013.

${ }^{4}$ In both past and current studies, the impact of tax parameters on investments is analyzed on an aggregated basis. Examples are Chirinko \& Wilson, 2008, who analyze the effect of the cost of capital on the capital-output ratio, and Klemm \& Van Parys, 2012, who use a panel of country data to analyze the impact of the corporate tax rate, tax holidays and investment allowances on private investments and FDI in developing countries.
} 
situations could arise because controlling for concurrent non-tax effects on investment proves to be difficult and because many macroeconomic variables move together over the business cycle (Hassett \& Hubbard, 2002). Against this background, it is not surprising that it has been difficult to show a significant association between investment and tax incentives in such research. To overcome these problems, researchers widely apply firm-level analyses. However, even though analyses based on firm-level data solve the stated problems to a great extent, empirical evidence on the impact of tax parameters (particularly of tax depreciation) on investment still paints a mixed picture, as shown in the following review of the literature.

Many studies have examined the impact of the cost of capital on investment (early examples are Cummins \& Hassett, 1992 and Cummins et al., 1994; for an overview, see Dwenger, 2010). However, Dwenger, 2010, points out that there is still no consensus regarding the size of the user cost elasticity and attempts to solve this conflict. Using panel data of German corporations from 1987 to 2007 taken from the HopPENSTEDT database, the author applies both a distributed lag model and an error correction model and concludes that avoiding methodological shortcomings leads to a user cost elasticity of almost negative one, which is the neoclassical benchmark. Yet, owing to the nature of the cost of capital specifications, tax depreciation is not directly but only indirectly taken into account through the user cost of capital. As shown in the following discussion, several studies directly analyze the impact of tax depreciation on investment and therefore eliminate problems with regard to measuring the user cost of capital.

Several researchers analyze the impact of the partial expensing of equipment provisions on investment, the so-called bonus depreciation, in the United States from 2002 to 2004. Desai \& Goolsbee, 2004, apply a tax-adjusted q-model and use (among other things) firm-level data of companies in the Compustat research file for the period from 1962 to 2003. They find that investment is positively associated with the partial expensing provisions but that the effects are too small to counteract the decrease in aggregate investment.

Cohen \& Cummins, 2006, use census monthly data of nominal shipments of capital goods and quarterly NIPA (National Income and Product Accounts) data. They apply a difference-indifference approach to determine whether the change in the growth rate of investment in capital goods induced by the bonus depreciation is different for assets with a long and a short tax life. On a theoretical basis, they expect a stronger reaction with regard to assets with a long tax life, attributable to bonus depreciation. However, their results support theory only to a very limited extent.

Another approach is taken by House \& Shapiro, 2008. They use quarterly US investment 
data from 1959 to 2006 for different types of capital, made available by the Bureau of Economic Analysis. They forecast investments for the years 2000 to 2006, based on the time period without bonus depreciation. In a second step, they calculate forecast errors and apply ordinary and weighted least squares to determine whether the calculated forecast errors can (partly) be explained by the bonus depreciation regime. They find that bonus depreciation has a strong effect on the structure of investments, i. e., qualified investment goods (assets with a recovery period of 20 years or less) respond more strongly to bonus depreciation. Among these qualified investment goods the response is strongest for goods with higher tax recovery periods.

Dauchy \& Martínez, 2008, analyze whether a change in the cost of capital attributable to bonus depreciation affects the change in investment-to-capital ratios. Using COMPUSTAT data, the change in investment-to-capital ratios is calculated at the firm level as the average investment-to-capital ratio three years before (1998 to 2000) minus three years after the accelerated depreciation regime (2002 to 2004). They find a small but significantly positive effect of bonus depreciation.

Hulse \& Livingstone, 2010, use quarterly firm-level data from Compustat between 1990 and 2006 and regress capital expenditure scaled by total assets on a set of explanatory variables. Among the explanatory variables, they include different indicator variables that indicate periods in which bonus depreciation was available. The expected positive coefficient of the indicator variables can only be shown in some but not in all regression estimates.

Additional studies focus not directly on the impact of the bonus depreciation regime on investment but on other effects of this reform. Miller et al., 2008, use quarterly and annual data of shipments in the general aviation aircraft industry from 1987 to 2005 and document a significant negative relation between bonus depreciation and the annual ratio of piston to (more expensive) turbine general aviation aircraft shipments. The findings are consistent with their expectations that the impact of bonus depreciation should be strongest for expensive aircraft. Key, 2008, examines market prices in the equine industry from 2001 to 2005 . The author finds a significant increase in prices during the period of the bonus depreciation regime (2002 to 2004) for horses that are eligible for bonus depreciation (yearlings) and does not find such an effect for horses that are not eligible for accelerated depreciation (broodmares). Similarly, Edgerton, 2011, uses datasets on sales of used farm machinery, used airplanes and used construction machines as well as Producer Price Indices to analyze the impact of investment incentives (investment tax credit and bonus depreciation) on prices of new and used equipment. He expects to find a wedge equal to the value of the incentives between the two prices since used capital does not qualify for the 
incentives. However, his analysis only confirms the effect with regard to the investment tax credit and not with regard to bonus depreciation. Taking this a step further, Edgerton, 2012, uses firmlevel data from COMPUSTAT and analyzes the effects of tax policy on investment decisions and the effect of accounting rules on that relation. According to his findings, investment tax credits have a stronger impact on investment than has accelerated depreciation because investment tax credits have, as opposed to tax depreciation, a positive effect on accounting profits.

Another study based on US data is carried out by Park, 2011. Instead of focusing on the bonus depreciation regime, he analyzes the 1999 shortening of the Alternative Minimum Taxation recovery period. He uses COMPUSTAT data and tax footnotes of financial statements and applies a difference-in-difference approach to examine whether firms' investments increase because of more favorable depreciation regulations. According to his findings, investment is increased by firms that fall under the Alternative Minimum Taxation regime around the 1999 reform (and therefore profit from the shortening of depreciation periods), while this finding does not hold true for the control group.

Studies on the impact of tax depreciation on investment that are not based on US data are relatively rare. Overesch, 2009, analyzes the impact of tax parameters on the level of investment for a panel of subsidiaries of German parent companies included in the Midi database. Applying ordinary least squares and considering tax depreciation by the present value of depreciation allowances, he finds a significantly positive effect of tax depreciation when he controls for groupspecific time-invariant effects. However, the effect vanishes when he includes firm fixed effects in his analyses and when he uses a dynamic panel data approach. He explains the missing effect by insufficient variation in the tax depreciation variable.

As is apparent from the preceding literature review, no clear evidence can be drawn with regard to the impact of tax depreciation on investment. Existing studies are mainly based on US data and primarily analyze the bonus depreciation regime in the US from 2002 to 2004. In addition, available studies are largely limited to stock-oriented and/or large companies. 


\section{Theoretical framework and derivation of the research hypothesis}

\subsection{Neoclassical Theory revisited}

Fundamental work with regard to Neoclassical Theory ${ }^{5}$ is carried out by Hirshleifer, 1958, Bailey, 1959 and Witte, 1963. The Neoclassical Model of investment behavior was outlined several times by Jorgenson in the mid-sixties, with the basic model being comprehensively outlined in Jorgenson, 1967. Jorgenson, 1963, Jorgenson, 1965 and Hall \& Jorgenson, 1967, extend the basic Neoclassical Model and include tax considerations. Unless noted otherwise, the following theoretical remarks are taken from these four references. ${ }^{6}$

The central feature of Neoclassical Theory is that it bases the accumulation of capital on the firm's objective to maximize the utility of a stream of consumption. This central feature is supplemented with the "standard neoclassical conditions of production" (Jorgenson, 1965, page 43). Accordingly, output, variable input and capital input are constrained by the technological possibilities of production, i. e., a production function that relates output to inputs of capital and labor services (see Equation E.5), and net investment (the rate of change of capital stock) equals gross investment less replacement (see Equation E.4) (Jorgenson, 1965). In addition, transforming the outcome of production into a stream of consumption is possible and prices for output, labor services, investment and consumption goods are fixed. Fixed prices over time imply that utility depends only on the choice of the production plan and not on the allocation of consumption over time (Jorgenson, 1967).

Utility maximization can be derived by choosing the production plan that maximizes either the net worth of the productive company (i. e., the present value of the firm) or the integral of discounted profits (or, simply, profit at each point of time) (Jorgenson, 1965, Jorgenson, 1967). Both methods lead to the same basic conclusions. The following description of the model is based on the maximization of the present value of the firm. The present value is defined as the integral of discounted net receipts after taxes, where the flow of net receipts at time $t$ is defined

\footnotetext{
${ }^{5}$ Neoclassical models were extended to so-called q-models. The q-theory (Tobin, 1969) states that companies invest as long as the ratio of the firm's market value to the replacement cost of capital (average q) is larger than one. The q-theory can be expanded to include taxation and is therefore applicable to linking investment behavior and stimulations in tax policy (Hall \& Jorgenson, 1967; Summers, 1981). However, as q can only be derived for listed companies, q-models are not further pursued in the remainder of the paper.

${ }^{6}$ In the first part of Jorgenson, 1967, he presents a Neoclassical Model of investment behavior with the underlying assumption of no lag in the completion of investment projects. In reality, a certain amount of time is necessary to complete new investment projects, and therefore, the actual and the desired level of capital stock may be different. Against this background, Jorgenson, 1963 and Jorgenson, 1967, extend the basic model and develop a so-called "distributed lag function" to account for such an instance. However, because the conclusions with regard to the impact of tax regulations on investment are the same in both models, I maintain the assumption of no lag in the completion of investment projects for the remainder of this section.
} 
as follows:

$$
R(t)=p(t) Q(t)-l(t) L(t)-q(t) I(t)
$$

Net receipts $R$ at time $\mathrm{t}$ are determined as output $Q(t)$ multiplied by the selling price $p(t)$ less labor costs $l(t) L(t)$ and costs for investment in durable goods $q(t) I(t)$. Net receipts are reduced by taxes at the company level $T(t)$, which are defined as the tax rate $\tau(t)$ multiplied by taxable income:

$$
T(t)=\tau(t)\left[p(t) Q(t)-l(t) L(t)-q\left(v(t) \delta+w(t) r-x(t) \frac{\dot{q}}{q}\right) K\right]
$$

Taxable income is determined as output $p(t) Q(t)$ minus variable input $l(t) L(t)$ minus other deductions for tax purposes. The first deduction is tax depreciation, which is defined as the book value of capital $K q$ multiplied by the rate of economic depreciation $\delta$ and the proportion $v(t)$ of economic depreciation that is deductible for tax purposes. The second deduction is interest expense, defined as the book value of capital $K q$ multiplied by the rate of interest for equity and debt $r$ and the proportion of interest deductible for tax purposes $w(t)$ (in a tax system without the possibility of notional interest deduction and without thin capitalization rules, $w(t)$ would equal the debt-to-equity ratio). The last term in Equation E.2 represents capital gains and losses that are relevant for tax purposes (the interpretation of $\frac{\dot{q}}{q}$ as the rate of both capital losses and capital gains can be found in Jorgenson \& Siebert, 1968a and Jorgenson \& Siebert, 1968b). These are determined as the book value of capital $K q$ multiplied by the rate of changes of prices for investment goods $\frac{\dot{q}}{q}$ and the proportion $x(t)$ of the capital gains and losses that is relevant for tax purposes (in a tax system in which realized capital gains and losses are fully relevant for tax purposes, $x(t)$ would, in general, equal the proportion of capital sold in the respective period). If prices decrease, $\frac{\dot{q}}{q}$ is negative, and capital losses occur. By contrast, if prices increase, $\frac{\dot{q}}{q}$ is positive, and companies holding the relevant investment goods receive capital gains.

Taken this as a basis, the present value of the firm (i. e., the integral of discounted net receipts after taxes) is defined by Equation E.3:

$$
W=\int_{0}^{\infty} e^{-r\left(1-\tau_{I}\right) t}[R(t)-T(t)] d t
$$

$W$ is the present value of the firm, and $r$ is the constant time rate of discount before taxation. $\tau_{I}$ is the tax rate of interest-bearing investments in the capital market, ${ }^{7}$ and the way of discounting

\footnotetext{
${ }^{7}$ In his earlier work, Jorgenson does not explicitly include the taxation of interest-bearing investments in the capital market $\left(1-\tau_{I}\right)$. Instead, he refers to $r$ as the "rate of time discount" (Jorgenson, 1967, page 141) or the "cost of capital" (Hall \& Jorgenson, 1967, page 392), i. e., he does not eliminate the possibility that $r$ is in fact an after tax rate in his model. In Hall \& Jorgenson, 1971, however, he explicitly uses the after-tax interest rate
} 
implies that time is defined as a continuous parameter. ${ }^{8}$

Maximization of the firm's net present value is subject to two constraints, derived from the "standard neoclassical conditions of production" (see above). The first constraint relates to net investment (or the time rate of change of the flow of capital services), which is determined as total investment less replacement, with replacements being a constant proportion $\delta$ of capital stock. ${ }^{9}$ Net investment $\dot{K}(t)$ is therefore formalized as follows:

$$
\dot{K}(t)=I(t)-\delta K(t)
$$

The second constraint is given by a production function with output $Q$ being a function of variable input $L$ and capital input $K$. The production function is rearranged as shown in Equation E.5 and is assumed to be strictly convex and twice differentiable, with marginal rates of substitution between inputs and marginal productivities of both inputs greater than zero. It becomes apparent from Equation E.5 that only a single output, one variable input and one capital input are considered. However, the model can easily be extended, and the restriction is not essential for the theory (Jorgenson, 1965).

$$
Q=F(K, L) \Leftrightarrow F(Q, L, K)=0
$$

Jorgenson, 1967, solves the optimization problem under two constraints using the EulerLagrange conditions. ${ }^{10}$ Equation E. 6 shows the Lagrange equation subject to optimization:

$$
\mathscr{L}=\int_{0}^{\infty} f(t) d t
$$

where:

$$
f(t)=e^{-r\left(1-\tau_{I}\right) t}[R(t)-T(t)]+\lambda_{0}(t) F(Q, L, K)+\lambda_{1}(t)(\dot{K}(t)-I(t)+\delta K(t))
$$

\footnotetext{
as a discount rate but does not differentiate between the corporate tax rate and the tax rate on interest-bearing investments in the capital market.

${ }^{8}$ The basic results of the model hold for both discrete and continuous time (see Jorgenson, 1965).

${ }^{9}$ Replacement investments generated by a given flow of expansion investments are deemed to be exponentially distributed over time and represent an infinite stream of investments. According to renewal theory, these investments approach a constant proportion of capital stock, regardless of how replacements for a single investment are distributed, how capital stock is developing and the age distribution of capital stock (Jorgenson, 1963, Jorgenson, 1965 and Jorgenson, 1967).

${ }^{10}$ The Euler-Lagrange equations or Euler necessary conditions are primarily used in optimization problems in the field of mechanics. However, because the Euler-Lagrange equations maximize integrals in the general form of $W=\int_{t_{1}}^{t_{2}} L(q, \dot{q}, t) d t$, they can also be used to maximize the above-noted present value of the firm. A complete derivation of the Euler necessary conditions can be found in Landau \& Lifshitz, 1976, page 2 to 4, for example.
} 
The Euler necessary conditions for a maximum of the present value of the firm as well as the applicable constraints can be derived from Equation E.6. Combining these conditions leads to the complete Neoclassical Model of investment. It is formalized in the following paragraph ${ }^{11}$ and consists of the marginal productivity conditions for labor and capital services:

$$
\begin{gathered}
\frac{\partial Q}{\partial L}=\frac{l}{p} \text { and } \frac{\partial Q}{\partial K}=\frac{c}{p} \\
\text { where } c=q\left[\left[\frac{1-\tau v}{1-\tau}\right] \delta+\left[\frac{1-\tau w}{1-\tau}\right] r+\left[\frac{-\tau_{I}}{1-\tau}\right] r-\left[\frac{1-\tau x}{1-\tau}\right] \frac{\dot{q}}{q}\right]
\end{gathered}
$$

and the production function and the assumption about replacement investments as side conditions:

$$
F(Q, L, K)=0 \quad \text { and } \quad \dot{K}(t)=I(t)-\delta K(t)
$$

The marginal productivity condition for labor services implies that a firm hires employees until the revenue of the additional output attributable to the new employee/the additional unit of work $\frac{\partial Q}{\partial L} p$ equals the wage expense $l$. Similarly, the marginal productivity condition for capital services implies that a firm acquires capital until the corresponding revenue $\frac{\partial Q}{\partial K} p$ equals the cost of capital $c$.

To derive the desired stock of capital, Jorgenson chooses (in all four references) a Cobb-Douglas production function of the following form:

$$
Q=A K^{\alpha} L^{\beta}
$$

where $Q$ is output, $K$ is capital input and $L$ is labor input. $A$ is the total factor productivity, $\alpha$ is the elasticity of the output with respect to capital stock, and $\beta$ is the elasticity of the output with respect to labor services. Jorgenson, 1965, explicitly assumes diminishing returns to scale and therefore that $\alpha+\beta<1$. Deriving the marginal productivity condition for the Cobb-Douglas production function and combining it with the marginal productivity condition noted above, he obtains the following relation:

$$
\frac{\partial Q}{\partial K}=\alpha A K^{\alpha-1} L^{\beta}=\alpha \frac{Q}{K}=\frac{c}{p}
$$

\footnotetext{
${ }^{11}$ A detailed derivation of the Neoclassical Model as well as the Euler necessary conditions can be found in the Appendix in Section E.8.1.
} 
When output is taken as determined by the production function and the marginal productivity condition for current input (given the actual level of capital stock), the desired level of capital $K^{*}$ can be defined from Equation E.12 as follows:

$$
K^{*}=\alpha \frac{p Q}{c}
$$

\subsection{Derivation of the impact of taxation on investment}

Equation E.13 shows that the optimal level of capital (and hence investments) is negatively related to the cost of capital. As noted above, the derivation of the Neoclassical Model of investment behavior is taken from Jorgenson, 1963, Jorgenson, 1965, Jorgenson, 1967 and Hall \& Jorgenson, 1967. Using this model as a basis, I differentiate the resultant cost of capital $c$ with respect to depreciation allowances for tax purposes (Equation E.15) and the corporate tax rate (Equation E.16) to derive the theoretical impact of taxation on investment. As in Jorgenson, 1963 and Jorgenson \& Siebert, 1968b, I assume that all capital gains and losses are transitory. ${ }^{12}$ The resultant cost of capital and the respective derivations are as follows: ${ }^{13}$

$$
\begin{aligned}
c & =q\left[\delta\left[\frac{1-\tau(t) v(t)}{1-\tau(t)}\right]+r\left[\frac{1-\tau(t) w(t)}{1-\tau(t)}\right]-r\left[\frac{\tau_{I}(t)}{1-\tau(t)}\right]\right] \\
\frac{\partial c}{\partial v} & =q\left[\frac{-\tau}{1-\tau}\right] \delta \\
\frac{\partial c}{\partial \tau} & =q\left[\left[\frac{1-v}{(1-\tau)^{2}}\right] \delta+\left[\frac{1-w}{(1-\tau)^{2}}\right] r-\left[\frac{\tau_{I}}{(1-\tau)^{2}}\right] r\right]
\end{aligned}
$$

Several conclusions can be drawn from Equations E.14 to E.16. First, the second and the third term on the right-hand side of Equation E.14 show that, as expected, the cost of capital is higher for higher interest rates $r$ as long as $1-\tau w-\tau_{I}>0$. The more interest expenses are deductible for tax purposes (i. e., the higher $w$ is), the lower is the cost of capital. Similarly, the higher the tax rate $\tau_{I}$ on interest-bearing investments in the capital market is, the lower is the cost of capital.

Equation E.15 shows that the impact of tax depreciation allowances on the cost of capital is negative and increasing in the tax rate, i. e., the higher the proportion of economic depreciation deductible for tax purposes is, the lower is the cost of capital. That is, the impact of tax

\footnotetext{
${ }^{12}$ I.e., $\frac{\dot{q}}{q}\left[\frac{1-\tau x}{1-\tau}\right]=0$. Even if capital gains and losses were not fully transitory, $\frac{\dot{q}}{q}$ and the whole term would be very small. The assumption should therefore not distort the theoretical results to any significant extent.

${ }^{13}$ This is done similarly to the procedure in Jorgenson, 1965. However, instead of differentiating cost of capital, Jorgenson directly differentiates the desired level of capital $K^{*}$.
} 
depreciation regulations on investment depends on the relation of tax depreciation to economic depreciation. In most European countries, tax depreciation is regulated in a way that after a specific number of years (the expected useful life of an asset), cumulated tax depreciation equals the purchase price. Hence, tax depreciation equals economic depreciation if timing effects are not taken into account or if the capital market interest rate is zero. When considering timing effects, the proportion of economic depreciation that is deductible for tax purposes is larger if tax depreciation is deductible in early years, i. e., the higher the present value of depreciation allowances is. Directly comparing the present values of depreciation allowances across countries is only a valid approach if economic depreciation is constant across countries and over time and differs only between asset types. This assumption seems valid for the purposes of this study given the conditions of a highly homogeneous European internal market. In addition, this assumption is also applied by other researchers (see, for example, Devereux et al., 2009).

The impact of the tax rate on the cost of capital is somewhat more complicated and becomes apparent from Equation E.16. The impact is zero, if tax depreciation equals economic depreciation $(v=1)^{14}$ and if either (notional) interest expenses for both equity and debt are deductible for tax purposes $(w=1)$ and there are no taxes on interest-bearing investments in the capital market $\left(\tau_{I}=0\right)$ or if no interest expenses are deductible for tax purposes $(w=0)$ and taxes on interest-bearing investments in the capital market equal 100 percent $\left(\tau_{I}=1\right)$. However, none of the analyzed countries' tax systems fulfills all of these criteria.

The impact of the tax rate on the cost of capital is positive if $1-v>0$, i. e., if tax depreciation is not larger than economic depreciation, and if $\tau_{I}$ is sufficiently small. The second term of Equation E.16 is always larger than zero because $w$ is generally between zero and one. Accordingly, the cost of capital can only depend negatively on the corporate tax rate if $1-v<0$, i. e., if tax depreciation exceeds economic depreciation, or if $\tau_{I}$ is considerably large, i. e., if the tax rate on interest-bearing investments in the capital market is high. In addition, $\delta(1-v) /(1-\tau)^{2}$ and/or $-r \tau_{I} /(1-\tau)^{2}$ must be larger in amount than the second term of the right-hand side of Equation E.16. This situation is generally known as a "tax paradox" and is analyzed in detail, for example, in Schneider, 1992 and Schneider, 2002.

To determine the impact of the tax rate on investment with regard to the countries considered in the following empirical analyses, Equation E.16 has to be analyzed with the respective tax regulations applied in the European Union. In general, the total of the two terms on the righthand side of Equation E.16 can assumed to be close to zero. When applying the average tax rate

\footnotetext{
${ }^{14}$ A similar conclusion is derived in Hall \& Jorgenson, 1971, page 17.
} 
for interest-bearing investments in the capital market $\left(\tau_{I}=0.3\right)$ and the average leverage of the companies included in the analysis $(w=0.6$, assuming that interest expenses on debt are fully deductible for tax purposes), it becomes apparent that the impact of the tax rate on investment is almost exclusively determined by $\delta(1-v) /(1-\tau)^{2}$, i. e., the relation of economic to tax depreciation. When comparing economic depreciation ${ }^{15}$ to tax depreciation for the sample companies, it is not possible to derive an unambiguous hypothesis, because economic depreciation is neither exclusively higher nor exclusively lower than tax depreciation. Rather, economic depreciation lies somewhere in between the lowest and the highest present value of tax depreciation for all types of assets. Hence, the impact of the statutory tax rate on investment remains an empirical question for the companies considered in the analysis and cannot be unambiguously solved by theory.

Against this background, I derive the following research hypothesis, stated in the alternative:

H1: The higher the present value of depreciation allowances for a specific asset type is, the higher are investments in the respective asset.

\section{Research design}

\subsection{Estimation approach}

To analyze whether more generous tax depreciation regulations are associated with higher investment in tangible and intangible fixed assets across countries, I estimate the following equation using ordinary least squares:

$$
\begin{aligned}
\text { investment rate }_{i, t} & =\beta_{0}+\beta_{1} \cdot \text { tax rate }_{c, t}+\beta_{2} \cdot \text { pvda }_{c, t}^{m}+\beta_{3} \cdot \text { pvda }_{c, t}^{b}+\beta_{4} \cdot p v d a_{c, t}^{p} \\
& +\beta_{5} \cdot W_{i / c, t}+\text { year }_{t}+\text { industry }_{i}+\text { year }_{t} \cdot \text { industry }_{i}+\epsilon_{i, t}
\end{aligned}
$$

The dependent variable, investment rate $e_{i, t}$, is defined in three different ways, as described in detail in Section E.4.2. Tax rate r,$t_{t}$ and the three $p v d a_{c, t}$ variables are the explanatory variables of interest. Tax rate c,$t_{t}$ is the country- and year-specific corporate tax rate (including local profit taxes where applicable). As derived in Section E.3.2, the impact of the tax rate on investment is ambiguous. $P v d a_{c, t}^{m}\left(p v d a_{c, t}^{b}, p v d a_{c, t}^{p}\right)$ is the present value of tax depreciation allowances for machinery (buildings, patents), derived from the applicable regulations on tax depreciation in

\footnotetext{
${ }^{15}$ Economic depreciation is assumed to be constant across countries and over time and is determined in accordance with Devereux et al., 2009.
} 
country $\mathrm{c}$ in year t. For a detailed description of the derivation of $p v d a_{c, t}$ see Section E.4.3. The impact of the present value of tax depreciation allowances on investment is expected to be positive, as stated in $\mathrm{H} 1$.

I include present values of depreciation allowances for three different asset types rather than one single value to account for the instance that tax depreciation regulations do not necessarily change in the same way with regard to different asset types. In fact, it is possible that the depreciation period for one asset type is reduced and that the depreciation period for another asset type is extended at the same time. In addition, the impact of tax depreciation on investment may differ with regard to the type of asset (i. e., $\beta_{2} \neq \beta_{3} \neq \beta_{4}$ ). First, it may be easier for firms to adjust their investment in machinery than in buildings since the planning horizon for buildings may generally be longer because of more complex decision scenarios and because buildings may be more expensive on average. Second, existing research has shown that investment in buildings and equipment is very different and that investment in commercial buildings "seems to follow a pattern linked to the availability of construction funds, rather than any rational estimate of future demand or excess capacity" (Clark, 1979; see page 318 in Clark, 1993, for details on this finding). Third, the present value of tax depreciation only applies to buildings and not to the related land. Since land is not depreciable for tax purposes but necessary for investments in buildings, the present value of tax depreciation for buildings is effectively lower than the amount directly derived from tax law. Against this background, it is expected that the impact of depreciation allowances on investment is more pronounced for machinery than for buildings.

$W_{i / c, t}$ is a vector of firm- and country-specific control variables. To be able to analyze whether differences in tax depreciation regulations over time and across countries are associated with different investment behavior, no country- or firm-indicator variables are included in Equation E.17. With this approach, it is not possible to control for time-fixed, country-specific or firmspecific effects. It is therefore essential to include sufficient control variables to mitigate the problem of correlated omitted variables. Year $_{t} \cdot$ industry $_{i}$ is an industry-year fixed effect, year and industry $y_{i}$ are the respective indicator variables, and $\epsilon_{i, t}$ is the company-specific error term.

To estimate the effects of tax depreciation on investment over time rather than across countries and to mitigate the problem of correlated omitted variables, Equation E.17 is estimated again with country and firm fixed effects, respectively. The inclusion of country- or firm-indicator variables has the advantage that unobservable, time-invariant effects on the country and/or firm level are controlled for, i.e., the problem of omitted variables is avoided to a great extent. I use a fixed effects instead of a random effects model, since the assumptions of the fixed effects 
model allow, in contrast to the random effects model, for the unobserved effects to be correlated with some of the explanatory variables. Because it is assumed that company- and countryspecific fixed effects are correlated with some of the explanatory variables (it is, for example, reasonable to assume that the risk behavior of a manager/a company is correlated with the company's cash flow and leverage or that the infrastructure of a country is correlated with GDP per capita), random effects models are not further considered as their results would, under these circumstances, be inconsistent (Wooldridge, 2009). This procedure is also supported by the Hausman test, which rejects the null hypothesis that both the random and the fixed effects models are consistent and therefore implies that only a fixed effects model is appropriate here. In addition, it has to be kept in mind that the random effects model indeed mitigates the problem of correlated omitted variables but that it does not completely eliminate the variation between firms. Hence, it is not possible with this model to fully isolate the impact of tax depreciation on investment over time.

Including country fixed effects in the regression equation implies that time-invariant variables at the country level (in this case EU 10 and eurozone) are excluded from the regression because of collinearity. In the case of firm fixed effects, the variable average tangibility and industry indicator variables are also omitted for reasons of collinearity. With the exception of these variables, the explanatory variables of the cross-section and those of the panel-data model are the same. The dependent variable(s), all firm- and country-specific control variables and two extensions of the basic model are briefly described in the following sections. Definitions of all variables as well as their units of measurement can be found in Table E.11 in the Appendix.

\subsection{Dependent variable(s)}

Two issues have to be taken into account when determining the dependent variable of this study. First, the applied definition should ensure that a gross investment rate is measured (i. e., gross of depreciation). By disregarding replacement investments, the effect of tax depreciation may be underestimated because generous tax depreciation regulations lead per se to a decrease in fixed assets. This is, however, only the case if financial accounting corresponds to tax accounting. Second, it may not be desirable to include intangible fixed assets in the investment rate, ${ }^{16}$ since the resultant definition may suffer from inaccuracies when patents are not purchased from third parties but are internally developed. First, capitalization of these assets may be

\footnotetext{
${ }^{16}$ The applied database includes only data on intangible and tangible fixed assets; no information on sub-items (such as patents, goodwill, buildings and machinery) is available.
} 
prohibited, leading to an underestimation of actual investments. Second, if capitalization of internally developed intangibles is not prohibited, it is to some extent up to the companies when to complete the development process and thus when to capitalize the developed patents. Hence, an increase in intangible fixed assets may not show the point of time of the actual investment but only the point of time of the patent's recognition on the balance sheet. In addition, investment in intangible fixed assets includes changes in not only patents but also, for example, goodwill, for which it is not possible to measure the present value of depreciation allowances because of data limitations.

Against this background, the desirable measure of investment is a gross investment rate, referring (only) to investments in tangible fixed assets. However, since only one aggregated amount of depreciation is available in the used set of company data rather than disaggregated amounts for different asset types, it is not possible to exactly determine the gross investment in tangible fixed assets. For reasons of robustness, I therefore apply three different dependent variables, as described in detail in the following section, each having particular advantages and shortcomings.

The first dependent variable (investment rate 1) measures the change in tangible and intangible fixed assets plus depreciation of firm i from year t- 1 to year $\mathrm{t}$ and is scaled by the total of tangibles and intangibles in year t-1. The derivation of this gross investment rate is formally described by Equation E.18.

$$
\text { investment rate }_{i, t}=\frac{\Delta \text { tangibles }_{i, t}+\Delta \text { intangibles }_{i, t}+\text { depreciation }_{i, t}}{\text { tangibles }_{i, t-1}+\text { intangibles }_{i, t-1}}
$$

The second dependent variable (investment rate 2 ) is defined as the change in tangible fixed assets in year t, scaled by tangible fixed assets in year t-1. This definition has the advantage that it is restricted to investment in tangible fixed assets, where one would generally expect an impact of tax depreciation regulations. However, investment rate 2 is a net investment rate. It is derived according to Equation E.19.

$$
\text { investment rate } 2_{i, t}=\frac{\Delta \text { tangibles }_{i, t}}{\text { tangibles }_{i, t-1}}
$$

Investment rate 3 is determined as the change in tangible fixed assets plus the depreciation of tangibles in year $t$, scaled by tangible fixed assets in year t-1. Depreciation of tangible fixed assets is estimated by the ratio of tangibles to the total of tangibles and intangibles in year t-1 
multiplied by the total amount of depreciation in year t. Investment rate 3 is therefore a gross investment rate in tangible fixed assets, but depreciation has to be estimated and is not available directly from the database. The third rate of investment is defined according to Equation E.20.

$$
\text { investment rate }_{i, t}=\frac{\Delta \text { tangible }_{i, t}+\frac{\text { tangibles }_{i, t-1}}{\text { tangible }_{i, t-1}+\text { intangibles }_{i, t-1}} \cdot \text { depreciation }_{i, t}}{\text { tangibles }_{i, t-1}}
$$

Firm-level data are generally provided in euro in the database that is used. Because companies are included in the sample that are residents of countries that do not belong to the Eurozone, it may be that the above-defined investment rates suggest positive (or negative) investments, even though these effects are solely attributable to an upward revaluation (or devaluation) of the respective local currency. To mitigate these effects, all euro values are converted into local currency for companies resident in a non-euro country before calculating the investment rates. The same procedure is applied for explanatory variables that may be subject to exchange rate effects. Company-specific yearly exchange rates are available in the database that is used.

\subsection{Key explanatory variables}

The explanatory variables of primary interest are the tax rate and the present values of depreciation allowances. ${ }^{17}$ Whereas the tax rate is determined as the statutory corporate tax rate plus local trade taxes if applicable, the present values of depreciation allowances are calculated by assuming acquisition costs of 100 for each type of asset in each year and discounting the resultant depreciation allowances by an appropriate interest rate. This procedure is carried out separately for buildings, machinery and patents. The resultant values are the present values of depreciation allowances for an investment in a specific asset type, country and year in percentage points. To exemplify this procedure, the calculation of pvda patents is shown in Equation E.21, where $c$ indicates the country, $t$ indicates the year, $i$ is the risk-free capital market interest after taxes and $\sum_{t=1}^{T}$ depreciation $n_{t}^{\text {patents }}=100$. By construction, the present values of depreciation allowances for each asset type are equal for companies in the same country in a specific year.

$$
\text { pvda patents }_{c, t}=\sum_{t=1}^{T} \text { depreciation }_{t}^{\text {patents }} \cdot(1+i)^{-t}
$$

Figure E.1 shows the present values of depreciation allowances for patents, which range from 69 to 87 percent. The lowest present value of depreciation allowances can be found in Bulgaria,

\footnotetext{
${ }^{17}$ Tax rates are obtained from the IBFD European Tax Handbooks for 1998 to 2007 and depreciation regulations are derived from Devereux et al., 2009.
} 
where patents are depreciated on a straight-line basis over 6.67 years. By contrast, patents are depreciated on a straight-line basis over five years in Germany, France and Poland (and in Slovakia after 1999), resulting in the highest present value of depreciation allowances for patents.

Figure E.1: Present values of depreciation allowances for patents by country and year

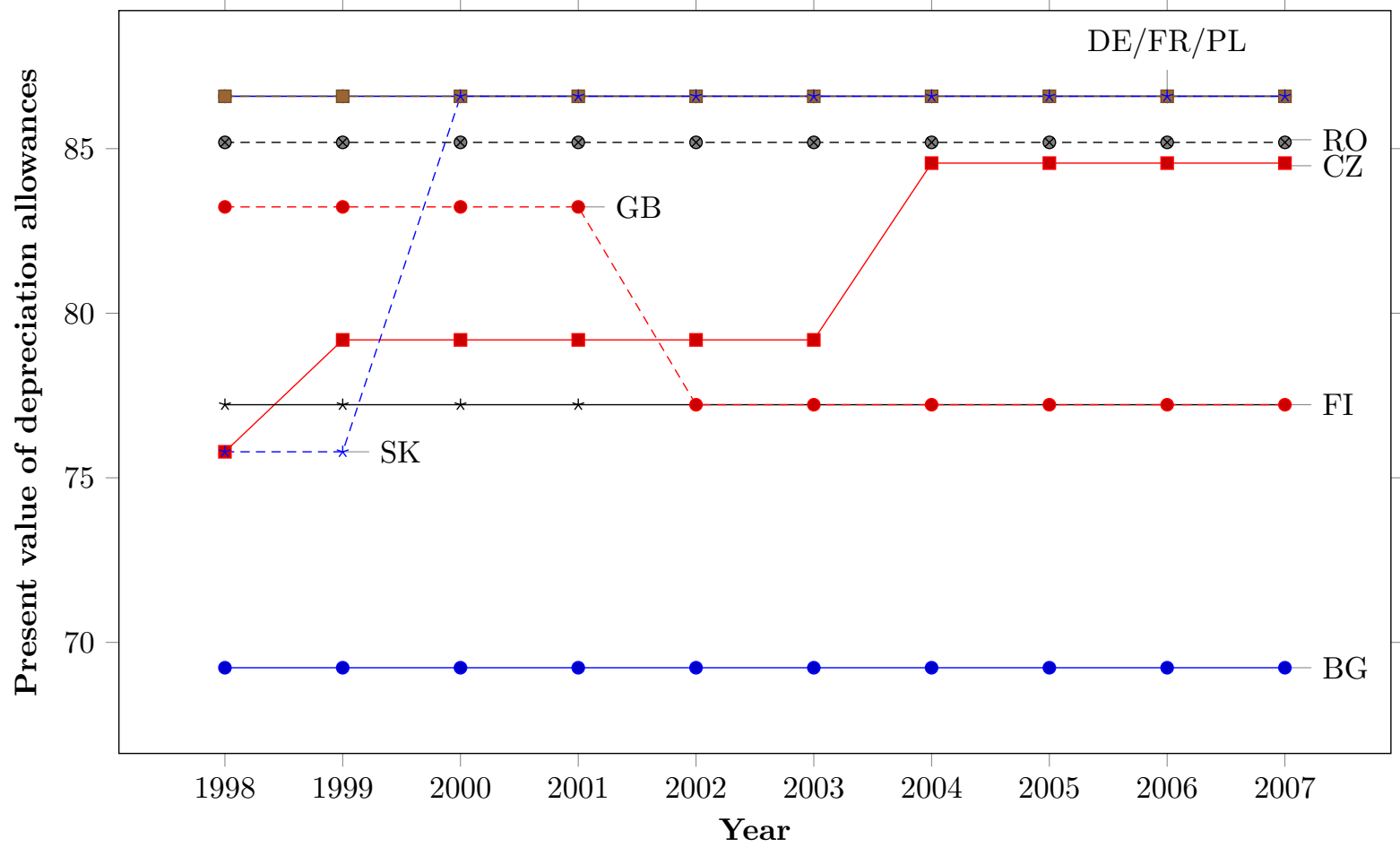

Figure E.1 shows the present values of depreciation allowances for patents between 1998 and 2007 in nine different countries. Present values of depreciation allowances are calculated assuming acquisition costs of 100 and a discount rate of five percent. Full expensing at the time of acquisition would therefore lead to a present value of depreciation allowances of 100. Data on depreciation regulations in the European Union are derived from Devereux et al., 2009. Source: Own diagram.

With regard to buildings (Figure E.2), the most restrictive depreciation regime is applied in Romania in 2004, where straight-line depreciation over 50 years leads to a present value of depreciation allowances of approximately 30 percent. The least restrictive depreciation regulations are applied in Slovakia after 2003. A special depreciation regime over 20 years leads to a present value of depreciation allowances of greater than 70 percent.

The present values of depreciation allowances for machinery are illustrated in Figure E.3. The most extreme values can be found for Poland. From 2003 to 2006, depreciation was 30 percent in the first year and 10 percent in the seven subsequent years, leading to a present value of approximately 90 percent. In 2007, straight-line depreciation over ten years led to a present value of depreciation allowances of less than 78 percent. It is apparent that there is sufficient variation in the present values of depreciation allowances both across countries and over time.

Choosing the "right" discount rate is of crucial importance because the discount rate explains why depreciation schedules actually affect investment decisions (Summers, 1987). According 
Figure E.2: Present values of depreciation allowances for buildings by country and year

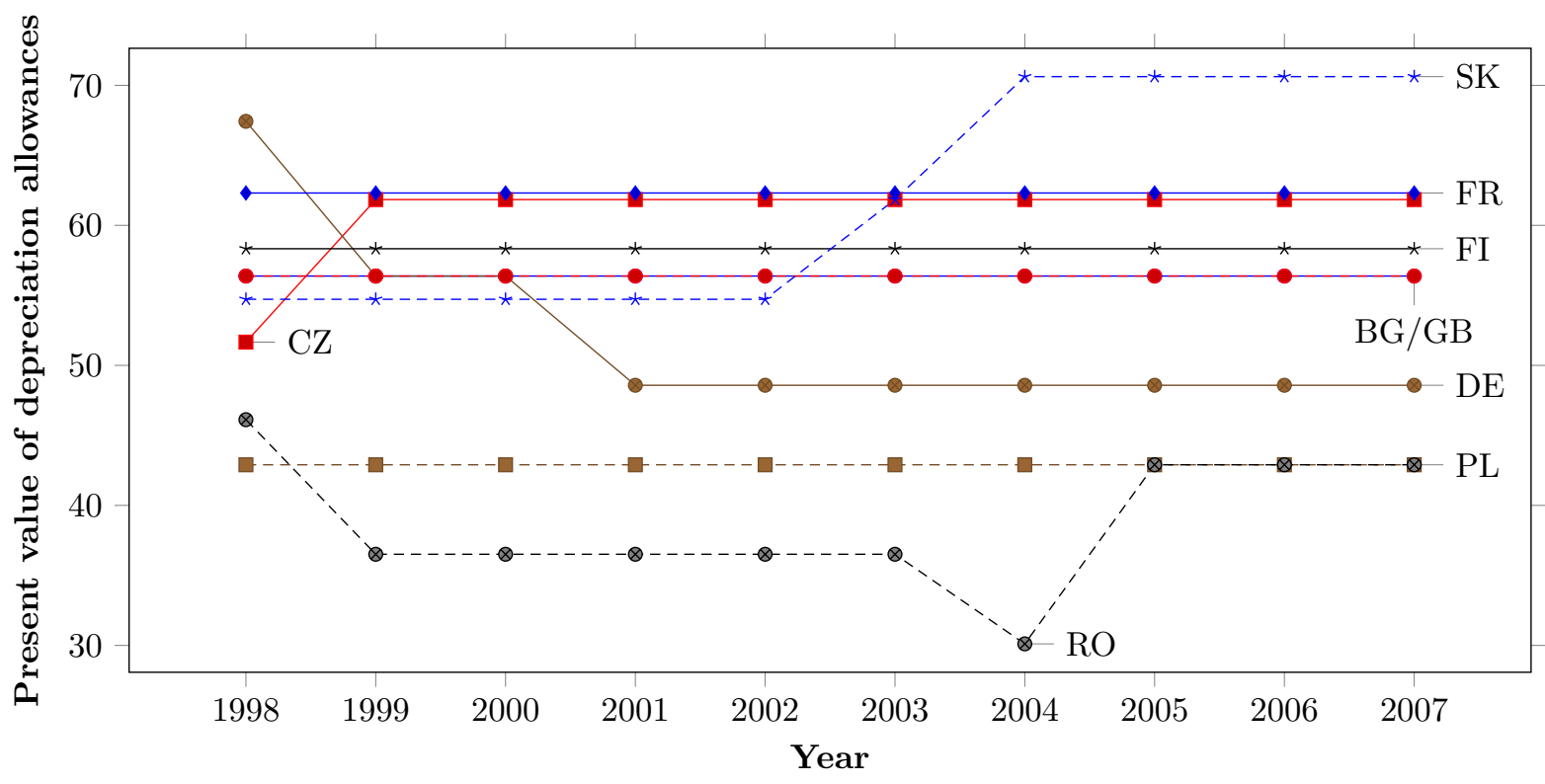

Figure E.3: Present values of depreciation allowances for machinery by country and year

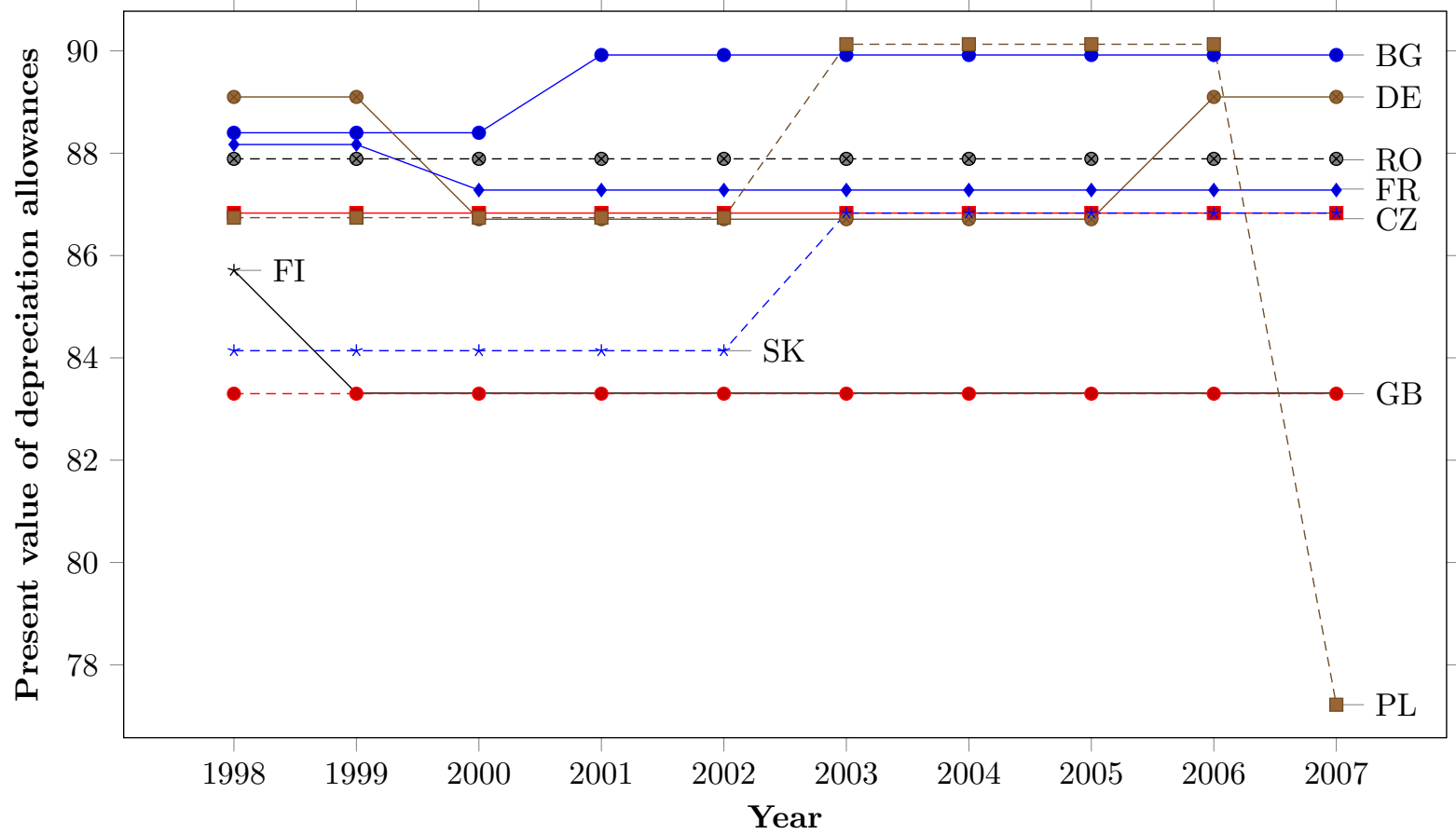

Figure E.2 (E.3) shows the present values of depreciation allowances for buildings (machinery) between 1998 and 2007 in nine different countries. Present values of depreciation allowances are calculated assuming acquisition costs of 100 and a discount rate of five percent. Full expensing at the time of acquisition would therefore lead to a present value of depreciation allowances of 100. Data on depreciation regulations in the European Union are derived from Devereux et al., 2009. Source: Own diagram.

to Summers, 1987, depreciation tax shields are nearly riskless after-tax cash flows and should (in theory) be discounted at an after-tax interest rate on risk-free assets. However, he also shows empirically that companies use discount rates for depreciation allowances that are much higher than the theoretically appropriate rate. With regard to the countries in the sample, the average 
after-tax interest rate for ten-year government bonds (which should be relatively risk free) is 3.86 percent. Against this background, I apply a discount rate of five percent in the main analysis. In addition, cross-checks are carried out where I apply the country-specific after-tax interest rate on ten-year government bonds, which does not significantly change the results.

\subsection{Firm-specific control variables}

One crucial factor affecting investment is cash flow. It is expected that firms invest more if they have high positive cash flows, because they are in the financial position to invest (see also Chirinko et al., 1999). Therefore, cash flow and the previous year's cash flow are included as control variables. To eliminate size effects, cash flow (the previous year's cash flow) is scaled by prior-year (year t-2) total assets. In addition, investment should be lower for firms facing financial constraints (for example, in the form of high debt interest rates). Therefore, the firmspecific leverage in the prior year is included as another control variable (for the exact definition, see Table E.11 in the Appendix).

Furthermore, it is expected that firms invest more in their first years of incorporation. I include an indicator variable year of incorporation, which equals one if a firm is in the first three years after its foundation. Similarly, investment should be higher for firms that generated a profit in the prior year, which is captured by an indicator variable that equals one if a firm had an operating profit larger than 50,000 euro in the preceding year. ${ }^{18}$

Another determinant of investment in fixed assets is tangibility (tangibility is defined as tangible plus intangible fixed assets divided by total assets). To overcome endogeneity concerns, I include a variable that measures average tangibility per company over all years available rather than current or lagged tangibility. ${ }^{19}$ In principle, one would expect that companies with high tangibility (i. e., a relatively high amount of fixed assets) invest more than companies with low tangibility. In addition, I include the logarithm of total assets in year t-1 to control for company size.

\subsection{Country-specific control variables}

To control for specific country characteristics, which may influence investment (for example, political stability, welfare, the available infrastructure, labor costs and unemployment), different

\footnotetext{
${ }^{18} \mathrm{I}$ do not include return on assets in the analysis as a relative measure for profitability as it is highly correlated with scaled cash flow.

${ }^{19}$ Average tangibility is calculated before selecting the sample companies, as described in Section E.5. Hence, even if only one or two firm-year observations are included in the regression analyses, average tangibility is calculated based on all firm-year observations available.
} 
country-level control variables are taken into account. Specifically, I include GDP per capita, GDP growth, inflation, treasury and unemployment rate, market size, hourly wages and the country risk. In addition, two indicator variables are included to indicate whether a country is a member of the EU 10 states (i. e., the variable equals one for Germany, France and the United Kingdom) and if a country is located in the Eurozone (i. e., the variable equals one for Germany, France and Finland).

GDP per capita and GDP growth are expected to have a positive impact on the level of investment because companies should invest more in economic upturns. In addition, GDP per capita can be considered an indicator for economic welfare, which may also positively influence investment.

The effect of inflation on investment is ambiguous. On the one hand, inflation favors real investments compared with interest-bearing investments in capital markets, i.e., one would expect a positive association between inflation and investment. On the other hand, it is often emphasized that inflation and the debt interest rate move closely in line with each other (see, for example, Alvarez et al., 2001). In this case, inflation would serve as a proxy for the debt interest rate and would be expected to be negatively associated with investment.

The treasury rate should have a negative impact on investment because high interest rates (as already shown above) lead to a high cost of capital. The association between the unemployment rate and investment is also expected to be negative since demand, production and investment capacity are higher when more people are employed. Market size is measured as the number of inhabitants and its impact on investment is ambiguous. On the one hand, a positive association between market size and investment is possible if a high number of inhabitants leads to high demand and, therefore, high investment. On the other hand, market size and investment would be negatively associated if companies in small, emerging economies grow faster (i. e., invest more) than companies in large, industrialized countries. Hourly wages should be negatively associated with investment because high hourly wages make investments more expensive. By contrast, production may be shifted from labor-intensive to capital-intensive projects if wages are high, leading to a positive association between wages and investment. However, the second effect is expected to be of secondary order. The country risk, taken from the OECD database, lies between zero (low-risk country) and seven (high-risk country) and is expected to be negatively associated with investment.

In general, countries within the EU 10 and countries within the Eurozone are thought of as countries with relatively strong business activity that are economically and politically stable. I 
therefore expect a positive coefficient for these variables.

\subsection{Extensions of the basic model}

Tax depreciation is only expected to have a positive impact on a company's tax burden if the company is profitable and does not have a tax loss carry-forward that reduces the tax burden to zero. In the case of tax loss carry-forwards, improved tax depreciation only leads to an increase of the loss carry-forwards rather than to an immediate decrease of tax payments. It can therefore be anticipated that the (positive) impact of tax depreciation regulations on investment is most strongly pronounced for companies that in fact have to pay taxes and that do not have a tax loss carry-forward. To test this expectation, I divide the sample into two groups of companies (those that have and those that do not have a tax loss carry-forward) and estimate separate regressions. Another possibility would be to interact the variables regarding tax depreciation with an indicator variable that shows whether a company is in the possession of a loss carry-forward. However, this procedure would restrict all remaining regression coefficients to be the same for the two groups. Because I expect the companies in the two groups to differ systematically with regard to the impact of the explanatory variables on investment, I estimate two different regression equations.

As the database applied contains financial rather than tax accounting data, it does not include data on tax loss carry-forwards. It is also not possible to use financial loss carry-forwards as a proxy for tax loss carry-forwards because the only available item in the applied database is other shareholders' funds, which includes (among others) capital and other reserves in addition to financial loss carry-forwards. I therefore estimate the existence of tax loss carry-forwards by applying three different criteria: (i) profit/loss for period ${ }_{t-1}<0$ (or, in countries that allow for the carry-back of tax losses, smaller than the maximum amount of loss carry-back), (ii) other shareholders' funds $<0$ and (iii) the company has an estimated tax loss carry-forward according to the micro-simulation model ASSERT. ${ }^{20}$ A company is considered to have a tax loss carryforward if in more than 50 percent of the years with available data, at least one of the three criteria is met.

Size-specific investment effects are estimated by interacting the variable controlling for company size (logarithm of total assets in year t-1) with the different present values of depreciation allowances. For reasons of robustness, I also include (instead of the logarithm of total assets)

\footnotetext{
${ }^{20}$ ASSERT is based on the same database as the existing study. A description of the model and how tax loss carry-forwards are determined can be found in Oestreicher et al., 2013.
} 
four indicator variables for company size (based on average total assets) and interaction terms between the size indicators and $p v d a_{c, t}$ in Equation E.17. With regard to size effects, two possible scenarios are conceivable. On the one hand, one might assume that large corporations respond to changes in tax depreciation more strongly than small and medium-sized corporations because they are financially more flexible and taxes may play a more important role in the decision-making process of these companies. On the other hand, large, multinational companies have a wide range of additional tax planning opportunities (e.g., tax rate differentials, financing strategies and transfer pricing) and are therefore not restricted to use tax depreciation for tax planning purposes. In addition, savings from improved depreciation regulations may not be very large relative to large companies' gains and losses, and therefore, these companies may not consider them important enough to cause a change to their investment plans. By contrast, savings from enhanced tax depreciation may be crucial for small companies. The expectations with regard to size effects are therefore ambiguous.

As shown in Section E.3.2, the tax rate is expected to have both a direct effect and an indirect effect on investment activity. The indirect effect of the tax rate on investment becomes apparent from Equation E.15. The higher the tax rate is, the stronger the positive impact of the present value of depreciation allowances is on investment. To determine the tax incentives from depreciation allowances, the present values of depreciation allowances should therefore be weighted by the applicable tax rate, and higher tax rates should increase the tax incentives from depreciation allowances. To account for this issue, interaction terms between the tax rate and the present values of depreciation allowances should be included in the analysis. However, because of a high correlation between the interaction terms and $p v d a$ as well as between the different interaction terms $(>0.9)$, including such interaction terms is not feasible.

\section{Sample selection and descriptive statistics}

The study is based primarily on company micro-data taken from the AMADEus database. AmADEus is a comprehensive pan-European database containing financial information on approximately nine million public and private companies in 38 European countries and is made available by the private database provider Bureau van Dijk. It contains standardized (consolidated and unconsolidated) annual accounts, financial ratios, and industry and ownership information for the companies included. ${ }^{21}$ Bureau van Dijk includes all companies for which plausible

\footnotetext{
${ }^{21}$ Owing to the nature of the available data (i. e., financial statement information), it is only possible to analyze the impact of tax depreciation on investment on an aggregate level rather than single investment decisions. This
} 
and up-to-date information is available. Thus, the completeness of the information covered in the database depends on its availability in each case. Statutory tax rates are obtained from the IBFD European Tax Handbooks for 1998 to 2007, and data on depreciation regulations in the European Union are derived from Devereux et al., 2009. Supplementary data on GDP per capita, GDP growth and inflation are taken from the WORLD BANK's web page. Data on treasury and unemployment rates, hourly wages and market size are derived from EUROSTAT; the country credit risk is made available by the OECD.

By construction, the second estimation approach applied analyzes the impact of changes in depreciation regulations (as well as in tax rates and other factors) over time. For comparability purposes, I include in both analyses only data on those countries where tax depreciation regulations were subject to changes in the sample period. Because tax regimes as well as tax rates differ for partnerships and corporations and the tax rate for partnerships is often dependent on the personal situation of the partners (which is not included in AMADEUs), I base the analyses only on incorporated companies.

Because the information available for the companies covered by AmADEus is not complete in all cases, additional limitations are necessary when applying the data. Hence, the analyses include only those firm-years for which complete (unconsolidated) datasets are available. To be included in the analyses, information on all variables in Table E.2 must be available. Attributable to the fact that data on tax depreciation regulations is only available from 1998, the dataset covers the period from 1998 to 2007. The described approach results in a sample of $2,883,155$ firm-year observations.

As the second column of Table E.1 shows, the sample is largely dominated by French and Romanian companies. To mitigate possible distortions of the results that may follow from an unequal number of observations for each country, I randomly choose 16,000 observations per country that are included in the pooled cross-section analysis. ${ }^{22}$ Since the number of observations is smaller than 16,000 in the original sample for Germany, Poland and Slovakia, the final sample consists of 131,558 firm-year observations. With regard to the panel data analysis, it is important that the sample consists of a sufficient number of observations over time for each firm. I therefore generally do not apply random sampling for the panel data analysis but select those (approximately 2,000) companies from each country for which the most observations over time are available. In the case of France, ten-year datasets are available for more than 500,000 cor-

\footnotetext{
should be kept in mind when interpreting the results because compensation effects may arise.

${ }^{22}$ Random sampling is done in STATA. In a first step, a random number is drawn for every observation. In a second step, the 16,000 observations of each country with the smallest random numbers are selected.
} 
Table E.1: Sample overview

\begin{tabular}{|c|c|c|c|c|c|c|c|}
\hline \multirow[b]{2}{*}{ Country } & \multirow{2}{*}{$\begin{array}{c}\text { Original sample } \\
\mathrm{N}(\mathrm{Obs})\end{array}$} & \multicolumn{6}{|c|}{ Random sample } \\
\hline & & Size 1 & Size 2 & Size 3 & Size 4 & $\mathrm{~N}(\mathrm{Obs})$ & $\mathrm{N}($ Firms $)$ \\
\hline \multicolumn{8}{|c|}{ Panel A: Pooled cross-section analysis } \\
\hline Bulgaria & 43,158 & 10,101 & 5,191 & 560 & 148 & 16,000 & 8,780 \\
\hline Czech Republic & 53,736 & 5,212 & 8,252 & 1,963 & 573 & 16,000 & 11,516 \\
\hline Germany & 14,961 & 1,471 & 5,768 & 2,889 & 4,833 & 14,961 & 7,042 \\
\hline Finland & 96,597 & 8,775 & 6,468 & 501 & 256 & 16,000 & 11,688 \\
\hline France & $2,212,995$ & 8,716 & 6,740 & 436 & 108 & 16,000 & 15,678 \\
\hline Great Britain & 80,170 & 6,367 & 7,531 & 1,516 & 586 & 16,000 & 11,716 \\
\hline Poland & 12,255 & 665 & 6,843 & 3,566 & 1,181 & 12,255 & 4,932 \\
\hline Romania & 360,941 & 14,060 & 1,868 & 65 & 7 & 16,000 & 14,974 \\
\hline Slovakia & 8,342 & 432 & 5,707 & 1,670 & 533 & 8,342 & 3,528 \\
\hline Total & $2,883,155$ & 55,799 & 54,368 & 13,166 & 8,225 & 131,558 & 89,854 \\
\hline \multicolumn{8}{|c|}{ Panel B: Panel data analysis } \\
\hline Bulgaria & 43,158 & 10,964 & 6,929 & 695 & 192 & 18,780 & 2,807 \\
\hline Czech Republic & 53,736 & 2,809 & 12,584 & 4,765 & 1,502 & 21,660 & 4,031 \\
\hline Germany & 14,961 & 1,471 & 5,768 & 2,889 & 4,833 & 14,961 & 7,042 \\
\hline Finland & 96,597 & 9,379 & 10,555 & 607 & 323 & 20,864 & 2,394 \\
\hline France & $2,212,995$ & 7,813 & 11,063 & 905 & 219 & 20,000 & 2,000 \\
\hline Great Britain & 80,170 & 4,324 & 11,490 & 1,952 & 950 & 18,716 & 2,312 \\
\hline Poland & 12,255 & 665 & 6,843 & 3,566 & 1,181 & 12,255 & 4,932 \\
\hline Romania & 360,941 & 18,440 & 1,540 & 19 & 1 & 20,000 & 2,854 \\
\hline Slovakia & 8,342 & 432 & 5,707 & 1,670 & 533 & 8,342 & 3,528 \\
\hline Total & $2,883,155$ & 56,297 & 72,479 & 17,068 & 9,734 & 155,578 & 31,900 \\
\hline
\end{tabular}

The table shows firm-year observations by country for the original sample (column 2), firm-year observations by country and size class (columns 3 to 6), firm-year observations by country (N(Obs)) and the number of firms in each country $(\mathrm{N}($ Firm $))$ for the random sample. Size class 1 : total assets $\leq 350,000$, size class 2 : total assets $\leq 4.840$ million, size class 3 : total assets $\leq 19.250$ million, size class 4 : total assets $>19.250$ million.

porations. I therefore randomly select 2,000 of these datasets. A similar procedure is applied for Romania. The complete sample selection procedure is illustrated in Table E.10 in the Appendix.

As already noted above, the second column of Table E.1 shows the distribution of firm-year observations per country for the original sample. The remaining columns display the distribution of firm-year observations by country and size class for the two random samples. In this context, size class is defined by the amount of total assets, i. e., size class 1 contains companies with total assets less than or equal to 350,000 , size class 2 comprises companies with total assets between 350,000 and 4.840 million, companies with total assets between 4.840 and 19.250 million are in size class 3, and size class 4 covers companies with total assets of more than 19.250 million. The size criteria correspond to the criteria defined in $\S \S 267$ and 267a of the German Commercial Code. It becomes apparent that the firm-year observations of small companies compose 42.41 (36.19) percent of all firm-year observations in the cross-section (panel data) analysis, whereas large companies only account for 6.25 (6.26) percent of the analyzed datasets. Column 7 (8) shows the total number of observations (companies) included in the analyses. It becomes apparent 
that the number of observations is approximately equal for the cross-section and the panel data analysis, whereas the number of companies is much smaller in the latter, which was the objective of the different sample selection procedures.

Table E.2: Summary statistics

\begin{tabular}{|c|c|c|c|c|c|c|c|c|}
\hline \multirow[b]{2}{*}{ Variable } & \multicolumn{4}{|c|}{$\begin{array}{c}\text { Pooled cross-section analysis } \\
\text { 131,558 observations } \\
\text { 89,854 companies }\end{array}$} & \multicolumn{4}{|c|}{$\begin{array}{c}\text { Panel data analysis } \\
155,578 \text { observations } \\
31,900 \text { companies }\end{array}$} \\
\hline & Mean & SD & Min & $\operatorname{Max}$ & Mean & SD & Min & $\operatorname{Max}$ \\
\hline Investment rate 1 & 0.716 & 3.028 & -1.000 & 63.500 & 0.628 & 2.638 & -1.000 & 63.500 \\
\hline Investment rate 2 & 0.424 & 2.638 & -1.000 & 49.509 & 0.366 & 2.279 & -1.000 & 49.509 \\
\hline Investment rate 3 & 0.723 & 2.933 & -1.000 & 54.611 & 0.631 & 2.531 & -1.000 & 54.611 \\
\hline Tax rate & 0.267 & 0.076 & 0.100 & 0.566 & 0.272 & 0.074 & 0.100 & 0.566 \\
\hline Pvda buildings & 54.466 & 8.916 & 30.110 & 70.620 & 54.613 & 8.931 & 30.110 & 70.620 \\
\hline Pvda machinery & 86.626 & 2.621 & 77.220 & 90.130 & 86.583 & 2.552 & 77.220 & 90.130 \\
\hline Pvda patents & 81.807 & 5.928 & 69.230 & 86.590 & 81.562 & 5.867 & 69.230 & 86.590 \\
\hline Scaled cash flow & 0.208 & 0.431 & -12.033 & 27.153 & 0.185 & 0.473 & -12.033 & 73.375 \\
\hline Scaled cash flow $w_{t-1}$ & 0.248 & 1.001 & -24.215 & 92.744 & 0.194 & 0.762 & -2.932 & 162.451 \\
\hline Leverage $_{t-1}$ & 0.604 & 0.256 & 0.000 & 1.000 & 0.578 & 0.250 & 0.000 & 1.000 \\
\hline Ln(total assets $)_{t-1}$ & 6.268 & 2.199 & 0.000 & 18.543 & 6.504 & 2.118 & 0.000 & 18.543 \\
\hline Average tangibility & 0.365 & 0.258 & 0.000 & 1.000 & 0.375 & 0.252 & 0.000 & 1.000 \\
\hline Year of incorporation & 0.071 & 0.257 & 0.000 & 1.000 & 0.022 & 0.148 & 0.000 & 1.000 \\
\hline Profit prior year & 0.428 & 0.495 & 0.000 & 1.000 & 0.468 & 0.499 & 0.000 & 1.000 \\
\hline Country risk & 1.064 & 1.578 & 0.000 & 6.000 & 1.111 & 1.649 & 0.000 & 6.000 \\
\hline Unemployment rate & 0.096 & 0.038 & 0.047 & 0.200 & 0.095 & 0.037 & 0.047 & 0.200 \\
\hline Hourly wages & 14.419 & 11.148 & 1.290 & 31.060 & 14.178 & 11.072 & 1.290 & 31.060 \\
\hline Inflation & 0.040 & 0.051 & 0.001 & 0.457 & 0.043 & 0.058 & 0.001 & 0.591 \\
\hline Treasury rate & 0.050 & 0.014 & 0.034 & 0.107 & 0.051 & 0.014 & 0.034 & 0.107 \\
\hline Market size & 16.871 & 1.028 & 15.454 & 18.229 & 16.828 & 1.018 & 15.454 & 18.229 \\
\hline GDP growth & 0.044 & 0.022 & -0.004 & 0.105 & 0.042 & 0.021 & -0.048 & 0.105 \\
\hline Ln (GDP per capita) & 10.103 & 1.098 & 8.282 & 12.740 & 10.134 & 1.134 & 8.282 & 12.740 \\
\hline$E U 10$ & 0.357 & 0.479 & 0.000 & 1.000 & 0.345 & 0.475 & 0.000 & 1.000 \\
\hline Eurozone & 0.357 & 0.479 & 0.000 & 1.000 & 0.359 & 0.480 & 0.000 & 1.000 \\
\hline
\end{tabular}

Company data are taken from the AmADEus database, tax rates are obtained from the IBFD European Tax Handbooks for 1998 to 2007, and depreciation regulations are derived from Devereux et al., 2009. Data on GDP growth, GDP per capita and inflation are taken from the WorLD BANK's web page (World Development Indicators). Data on treasury and unemployment rates, hourly wages and market size are derived from EUROSTAT, and country risk is the country's credit risk as measured by the OECD. The dependent variables are winsorized at the 0.1 percent level before random sampling.

Table E.2 shows descriptive statistics for the variables that are used in the cross-section and the panel data analysis. The exact definitions of all variables as well as their units of measurement and the expected signs of their coefficients can be found in Table E.11 in the Appendix. Tables E.12 to E.13 in the Appendix show the correlations for all considered variables in the data sample for the cross-section and the panel analysis.

The first three variables in Table E.2 are the dependent variables as described in Section E.4.2. To eliminate the influence of outliers that are probably attributable to accounting errors, 
the dependent variables are winsorized at the 0.1 percent level before the (random) samples are selected. The relatively high mean investment ratios have to be interpreted against the background that the sample largely consists of small companies (i. e., investments of small euro amounts may lead to large changes in investment rates because the initial amount of assets is very small). In addition, it has to be taken into account that the data may suffer from survivorship bias (i. e., insolvent companies likely to show small investment ratios may not be covered by the database).

When comparing descriptive statistics for the pooled cross-section and the panel data analysis, it is noteworthy that the investment rates are generally smaller and have a smaller standard deviation for the panel data sample. Whereas the smaller mean value results from the fact that corporations in the panel data sample are, on average, larger (as indicated by the mean value of $\left.\ln (\text { total assets })_{t-1}\right)$, the smaller standard deviation indicates that the sample is more homogeneous, i. e., the number of different companies is smaller in the panel data sample. Furthermore, the cash flow variables are, on average, slightly smaller for the panel data sample. In addition, the mean value of the year of incorporation indicator variable is much smaller for the panel data sample, which is not surprising; the panel data sample consists of the companies with the most available firm-year observations. Apart from these differences, the two data samples are very similar. The sample selection procedure with regard to the panel data analysis should therefore not distort the results to any significant extent. ${ }^{23}$

\section{Results}

\subsection{Cross-section analyses}

The first set of regressions analyzes the impact of tax depreciation on investment in the crosssection. The regression results of Equation E.17 are shown in Table E.3. As discussed in Section E.4.1, three different dependent variables are applied, and the sample is divided into companies that are expected to have and those that are expected not to have a tax loss carry-forward. The regressions are estimated using ordinary least squares. The coefficients in Table E.3 show the estimated impact of the explanatory variables on scaled investment.

First, as shown in Table E.3, the results of the three regressions for companies without tax loss carry-forwards (columns 2, 4 and 6) are relatively similar and largely correspond to the expectations. As already shown in earlier studies, the statutory tax rate is significantly negatively

\footnotetext{
${ }^{23}$ The high maximum values of the inflation rate are attributable to the high inflation in Romania in the 1990s.
} 
Table E.3: Pooled cross-section estimates

\begin{tabular}{|c|c|c|c|c|c|c|}
\hline \multirow[t]{2}{*}{ Variable } & \multicolumn{2}{|c|}{ Investment rate 1} & \multicolumn{2}{|c|}{ Investment rate 2} & \multicolumn{2}{|c|}{ Investment rate 3} \\
\hline & No LCF & $\mathrm{LCF}$ & No LCF & $\mathrm{LCF}$ & No LCF & $\mathrm{LCF}$ \\
\hline \multirow[t]{2}{*}{ Tax rate } & $-1.544^{* * *}$ & 0.270 & $-1.508^{* * *}$ & 0.513 & $-1.691^{* * *}$ & 0.297 \\
\hline & $(-3.37)$ & $(0.31)$ & $(-3.80)$ & $(0.72)$ & $(-3.89)$ & $(0.37)$ \\
\hline \multirow[t]{2}{*}{ Pvda machinery } & $0.011^{* *}$ & 0.008 & $0.010^{* *}$ & 0.008 & $0.010^{* *}$ & 0.006 \\
\hline & $(2.09)$ & $(1.00)$ & $(2.28)$ & $(1.07)$ & $(2.11)$ & $(0.80)$ \\
\hline \multirow[t]{2}{*}{ Pvda buildings } & $-0.017^{* * *}$ & -0.005 & $-0.010^{* * *}$ & -0.000 & $-0.015^{* * *}$ & -0.002 \\
\hline & $(-5.40)$ & $(-0.64)$ & $(-4.17)$ & $(-0.06)$ & $(-5.48)$ & $(-0.33)$ \\
\hline \multirow[t]{2}{*}{ Pvda patents } & $0.010^{* *}$ & 0.014 & & & & \\
\hline & $(1.97)$ & $(1.28)$ & & & & \\
\hline \multirow[t]{2}{*}{ Scaled cash flow } & $1.123^{* * *}$ & $1.309^{* * *}$ & $0.942^{* * *}$ & $1.159^{* * *}$ & $1.075^{* * *}$ & $1.293^{* * *}$ \\
\hline & $(10.93)$ & $(5.55)$ & $(10.98)$ & $(5.67)$ & $(11.42)$ & $(5.82)$ \\
\hline \multirow{2}{*}{ Scaled cash flow $_{t-1}$} & 0.031 & 0.126 & 0.031 & 0.088 & 0.034 & 0.109 \\
\hline & $(1.22)$ & $(1.32)$ & $(1.26)$ & $(0.95)$ & $(1.31)$ & $(1.08)$ \\
\hline \multirow[t]{2}{*}{ Leverage $_{t-1}$} & $0.153^{* * *}$ & -0.116 & $0.153^{* * *}$ & -0.017 & $0.159^{* * *}$ & -0.085 \\
\hline & $(3.65)$ & $(-1.26)$ & $(4.20)$ & $(-0.23)$ & $(3.93)$ & $(-0.98)$ \\
\hline \multirow[t]{2}{*}{$\operatorname{Ln}(\text { total assets })_{t-1}$} & -0.007 & -0.007 & $0.015^{* *}$ & 0.001 & -0.011 & -0.017 \\
\hline & $(-0.85)$ & $(-0.49)$ & $(2.00)$ & $(0.13)$ & $(-1.30)$ & $(-1.27)$ \\
\hline \multirow[t]{2}{*}{ Average tangibility } & $-0.973^{* * *}$ & $-1.043^{* * *}$ & $-0.424^{* * *}$ & $-0.461^{* * *}$ & $-0.937 * * *$ & $-0.987 * * *$ \\
\hline & $(-27.06)$ & $(-12.47)$ & $(-13.18)$ & $(-6.47)$ & $(-26.28)$ & $(-12.09)$ \\
\hline \multirow[t]{2}{*}{ Year of incorporation } & $0.244^{* * *}$ & $0.432^{* * *}$ & $0.244^{* * *}$ & $0.406^{* * *}$ & $0.275^{* * *}$ & $0.473^{* * *}$ \\
\hline & $(4.90)$ & $(3.37)$ & $(5.34)$ & $(3.65)$ & $(5.54)$ & $(3.75)$ \\
\hline \multirow[t]{2}{*}{ Profit prior year } & -0.041 & -0.027 & -0.029 & -0.043 & -0.031 & -0.020 \\
\hline & $(-1.44)$ & $(-0.47)$ & $(-1.16)$ & $(-1.01)$ & $(-1.15)$ & $(-0.38)$ \\
\hline \multirow{2}{*}{ Country risk } & -0.044 & -0.082 & 0.018 & -0.016 & 0.001 & -0.030 \\
\hline & $(-1.53)$ & $(-1.60)$ & $(1.16)$ & $(-0.52)$ & $(0.04)$ & $(-0.95)$ \\
\hline \multirow[t]{2}{*}{ Unemployment rate } & -0.273 & -1.980 & -0.260 & $-1.590^{*}$ & 0.530 & -0.947 \\
\hline & $(-0.44)$ & $(-1.62)$ & $(0.587)$ & $(-1.68)$ & $(1.01)$ & $(-0.89)$ \\
\hline \multirow[t]{2}{*}{ Hourly wages } & $-0.028^{* * *}$ & -0.010 & $-0.019^{* * *}$ & -0.006 & $-0.026^{* * *}$ & -0.010 \\
\hline & $(-7.85)$ & $(-1.29)$ & $(-6.27)$ & $(-0.99)$ & $(-7.62)$ & $(-1.35)$ \\
\hline \multirow[t]{2}{*}{ Inflation } & $0.748^{*}$ & 0.820 & 0.453 & 0.151 & 0.551 & 0.211 \\
\hline & $(1.77)$ & $(0.93)$ & $(1.26)$ & $(0.19)$ & $(1.40)$ & $(0.24)$ \\
\hline \multirow[t]{2}{*}{ Treasury rate } & $-7.283^{* * *}$ & 3.127 & $-4.628^{* *}$ & 4.804 & $-8.023^{* * *}$ & 3.628 \\
\hline & $(-3.47)$ & $(0.91)$ & $(-2.51)$ & $(1.48)$ & $(-3.96)$ & (1.03) \\
\hline \multirow[t]{2}{*}{ Market size } & $-0.236 * * *$ & -0.111 & $-0.164^{* * *}$ & -0.060 & $-0.220 * * *$ & -0.077 \\
\hline & $(-4.75)$ & $(-1.10)$ & $(-4.02)$ & $(-0.70)$ & $(-4.84)$ & $(-0.79)$ \\
\hline GDP growth & 1.481 & 2.184 & $1.415^{*}$ & 0.975 & $1.661^{*}$ & 1.646 \\
\hline & $(1.42)$ & $(1.06)$ & $(1.69)$ & $(-0.23)$ & $(1.81)$ & $(0.89)$ \\
\hline Ln(GDP per capita) & $0.080 * * *$ & -0.027 & $0.050 * *$ & -0.035 & $0.095^{* * *}$ & -0.007 \\
\hline & $(2.94)$ & $(-0.52)$ & $(2.19)$ & $(-0.87)$ & $(3.72)$ & $(-0.16)$ \\
\hline EU 10 & $0.736^{* * *}$ & 0.218 & $0.581^{* * *}$ & 0.115 & $0.786^{* * *}$ & 0.241 \\
\hline & $(4.85)$ & $(0.78)$ & $(4.37)$ & $(0.45)$ & $(5.32)$ & $(0.83)$ \\
\hline Eurozone & $0.248^{* * *}$ & -0.049 & $0.194^{* * *}$ & -0.100 & $0.266^{* * *}$ & -0.007 \\
\hline & $(3.96)$ & $(-0.36)$ & $(4.11)$ & $(-0.97)$ & $(5.13)$ & $(-0.06)$ \\
\hline Constant & $3.808^{* * *}$ & 1.333 & $2.565^{* * *}$ & 0.676 & $4.066^{* * *}$ & 1.481 \\
\hline & $(4.08)$ & $(0.75)$ & $(3.20)$ & $(0.42)$ & $(4.49)$ & $(0.80)$ \\
\hline Number of observations & 107,033 & 24,525 & 107,033 & 24,525 & 107,033 & 24,525 \\
\hline $\mathrm{R}^{2}$ & 0.042 & 0.047 & 0.035 & 0.044 & 0.042 & 0.049 \\
\hline Prob $>F$ & 0.000 & 0.000 & 0.000 & 0.000 & 0.000 & 0.000 \\
\hline
\end{tabular}

The table shows the linear regression results for firm investment behavior, estimated over the period from 1998 to 2007. The dependent variables are different (gross) investment rates, as defined in Section E.4.2. See Table E.11 for a description of the dependent and independent variables. Industry, year and industry-year indicator variables are included in all specifications but are not reported. Standard errors allow for heteroskedasticity and are clustered by firm; t-values are shown in parentheses. ${ }^{*}, * *$ and $* * *$ indicate statistical significance at the ten-, five- and one-percent level, respectively. Prob $>$ F shows the p-value associated with the F-test for the null hypothesis that all coefficients shown in the table are equal to zero. 
associated with investment activity. ${ }^{24} \mathrm{~A}$ one percentage point increase in the statutory tax rate leads to a decrease in the investment ratio (depending on its definition) of between 1.51 and 1.69 percentage points.

As derived from theory, the present value of depreciation allowances for machinery is positively associated with scaled investment. A one percentage point increase in pvda machinery would lead to an increase in the investment ratio of between 1.00 and 1.10 percentage points. Similarly, an increase in the present value of depreciation allowances for patents would lead to an increase in the investment rate of 1.00 percentage point. All four coefficients are statistically significant at the 10-percent level. However, as already discussed above, it is not possible to differentiate whether the positive coefficient for pvda patents is attributable to increased investment activity or (at least in the case of internally developed patents) companies' regulation of the development process to complete the patents (and recognize them on their balance sheet) in periods of favorable depreciation regulations. In addition, the results with regard to the present values of depreciation allowances have to be considered against the background that it is not possible to determine gross investment in one specific asset type. Therefore, the size of the coefficients in particular has to be interpreted with caution. The coefficient of pvda buildings does not have the expected sign, indicating that investment in buildings follows a more complex path than investment in machinery, as discussed above. In addition, the missing effect may also be attributable to the fact that small companies (which dominate the sample; see Table E.1) may not own buildings.

With regard to the additional explanatory variables, the expectations are largely confirmed. As expected, the impact of operating cash flow on investment is significantly positive (between 0.942 and 1.123). The coefficient of the previous year's operating cash flow is also positive, though relatively small and not significant. The positive coefficient for the leverage variable seems counterintuitive at first because one would expect firms facing financial constraints to invest less. However, Becker et al., 2013, use a similar specification and likewise find a positive association between leverage and scaled investment. The coefficient of average tangibility is negative and significant, which means that companies with a higher ratio of fixed assets invest relatively less in these assets than companies with a lower average tangibility. When interpreting this result, it should be kept in mind that the dependent variable shows the investment ratio

\footnotetext{
${ }^{24}$ It is often suggested that firms have the choice between making investments and distributing dividends to their shareholders. Particularly for small, owner-managed firms, it may be reasonable to assume that investment decisions are also driven by the personal income tax rate on dividends. However, including this tax rate does not qualitatively change the results.
} 
rather than the investment amount in euro and that the average amount of fixed assets in hightangibility companies is much higher than the average amount of fixed assets in low-tangibility companies (7.1 million versus 2.7 million). Therefore, it is possible that, in absolute terms, companies with a high tangibility invest more than companies with a low ratio of fixed assets. The indicator variable showing whether a company is in its first three years after incorporation has a positive coefficient, indicating that firms invest more intensively shortly after their formation. The coefficient of hourly wages is significantly negative, supporting the theory that firms invest more when labor costs are low. In a similar way, one can observe a significant negative coefficient for the treasury rate, in line with the prediction that firms invest less if the cost of capital is high. The coefficient of the market-size variable is significantly negative, supporting the theory that companies grow faster in small, emerging economies than in large, fully industrialized economies. The coefficients of GDP per capita, EU10 and eurozone are positive and correspond to the expectations.

As expected, companies with a tax loss carry-forward (columns 3, 5 and 7 in Table E.3) consider neither the tax rate nor tax depreciation regulations when determining their level of investment. In all three regression specifications, the respective coefficients are not significant at any conventional level. In addition, most country-specific control variables that have a significant impact on investment for the group of companies that do not have a tax loss carry-forward are not significant for the other group of companies. Furthermore, Table E.3 shows that the coefficient of scaled cash flow is significant and larger for companies that have a tax loss carry-forward. This result is reasonable because the two groups likely differ with regard to not only the existence of a tax loss carry-forward but also their financial situation in general, i. e., companies with a tax loss carry-forward may tend to have financial constraints. Against this background, it makes sense that the impact of scaled cash flow on investment is stronger for companies that have a tax loss carry-forward.

In addition, the results in Table E.3 support the method of differentiating between companies that do and companies that do not have tax loss carry-forwards by estimating two different regressions rather than including interaction variables between the tax status and the present values of depreciation allowances. In the case of interaction variables, the coefficients of all variables except for the one being interacted with the tax status are restricted to be the same for both groups. However, it becomes apparent from Table E.3 that the coefficients for the two groups differ with regard to not only the present value of depreciation allowances but also other variables. Against this background, the following analyses are restricted to companies that do 
not have loss carry-forwards for tax purposes, which should be considered when interpreting the results.

To estimate the size-specific effects of tax depreciation on investment, I interact the variable controlling for size $\left(\ln (\text { total assets })_{t-1}\right)$ with the present values of depreciation allowances. Based on the results presented above, the analysis is only carried out for companies that do not have a tax loss carry-forward. The results for the three different dependent variables are shown in Table E.4. The coefficients of the tax rate are still negative but are smaller than those in Table E. 3 and are only significant for investment rate 2 and investment rate 3 . The main effects of all three present values of depreciation allowances are now positive and significant at the one-percent level. The interaction terms of the size variable and the present values of depreciation allowances show that the effect of tax depreciation on investment decreases as the size of companies increases. Hence, the impact of depreciation regulations on the investment ratio is most strongly pronounced for small companies, which is consistent with the theory that small companies (compared with large companies) are heavily dependent on carrying out tax planning via tax depreciation because they lack additional tax planning opportunities. The variable controlling for company size is now positive and significant, indicating that larger firms invest relatively more than smaller firms.

To determine the economic effects of tax depreciation on investment, I divide the sample into two size classes. Small (large) companies are companies with average total assets below (above) the median of average total assets. The estimated economic effects of a difference in the present value of depreciation allowances for machinery of 2.390 percentage points (this is, for example, the case for declining-balance depreciation of between 20 and 30 percent with a useful life of seven years) are shown in Table E.5. The items that are used to estimate the economic effects are shown in lines 1 to 6 . Mean denominator in $T €$ refers to the mean denominator of the respective investment rate, i.e., the previous year's tangible plus intangible fixed assets in the case of investment rate 1 and the previous year's tangibles in the case of investment rates 2 and 3 . In a first step, the main effect (line 7 ) is calculated by multiplying the change in the present value of depreciation allowances for machinery with the respective coefficient. In a second step, the interaction effect is determined (line 8) by multiplying the change in the present value of depreciation allowances for machinery with the respective coefficient and the mean size variable of the respective size group. The investment rate's change (line 9) is the sum of the two effects. Lines 10 and 11 show the mean percentage changes of the investment rates as well as the mean changes of investment in euro. Table E.5 shows that a difference of declining-balance 
Table E.4: Pooled cross-section estimates including size effects

\begin{tabular}{|c|c|c|c|}
\hline Variable & Investment rate 1 & Investment rate 2 & Investment rate 3 \\
\hline \multirow[t]{2}{*}{ Tax rate } & -0.690 & $-1.192^{* * *}$ & $-1.227 * * *$ \\
\hline & $(-1.49)$ & $(-3.01)$ & $(-2.82)$ \\
\hline \multirow[t]{2}{*}{ Pvda machinery } & $0.147^{* * *}$ & $0.097^{* * *}$ & $0.135^{* * *}$ \\
\hline & $(7.81)$ & $(6.09)$ & $(7.69)$ \\
\hline \multirow[t]{2}{*}{ Pvda mach. $* \ln (\text { total assets })_{t-1}$} & $-0.017 * * *$ & $-0.011^{* * *}$ & $-0.015^{* * *}$ \\
\hline & $(-7.96)$ & $(-5.99)$ & $(-7.79)$ \\
\hline \multirow[t]{2}{*}{ Pvda buildings } & $0.022^{* * *}$ & $0.013^{* * *}$ & $0.020^{* * *}$ \\
\hline & $(3.78)$ & $(2.75)$ & $(3.77)$ \\
\hline \multirow[t]{2}{*}{ Pvda buil. $* \ln (\text { total assets })_{t-1}$} & $-0.007 * * *$ & $-0.004^{* * *}$ & $-0.006^{* * *}$ \\
\hline & $(-8.91)$ & $(-6.33)$ & $(-8.62)$ \\
\hline \multirow[t]{2}{*}{ Pvda patents } & $0.050^{* * *}$ & & \\
\hline & $(5.83)$ & & \\
\hline \multirow{2}{*}{ Pvda pat. $* \ln (\text { total assets })_{t-1}$} & $-0.005^{* * *}$ & & \\
\hline & $(-5.12)$ & & \\
\hline \multirow[t]{2}{*}{$\operatorname{Ln}(\text { total assets })_{t-1}$} & $2.237^{* * *}$ & $1.160^{* * *}$ & $1.640^{* * *}$ \\
\hline & $(9.76)$ & $(6.85)$ & $(8.80)$ \\
\hline \multirow[t]{2}{*}{ Scaled cash flow } & $1.147^{* * *}$ & $0.953^{* * *}$ & $1.092^{* * *}$ \\
\hline & $(11.06)$ & $(11.04)$ & $(11.52)$ \\
\hline \multirow[t]{2}{*}{ Scaled cash flow $_{t-1}$} & 0.033 & 0.032 & 0.035 \\
\hline & $(1.27)$ & $(1.28)$ & $(1.34)$ \\
\hline \multirow[t]{2}{*}{ Leverage $_{t-1}$} & $0.162 * * *$ & $0.167 * * *$ & $0.178^{* * *}$ \\
\hline & $(3.85)$ & $(4.55)$ & $(4.40)$ \\
\hline \multirow[t]{2}{*}{ Average tangibility } & $-0.960 * * *$ & $-0.418^{* * *}$ & $-0.928^{* * *}$ \\
\hline & $(-26.70)$ & $(-13.00)$ & $(-26.04)$ \\
\hline \multirow[t]{2}{*}{ Year of incorporation } & $0.244^{* * *}$ & $0.248^{* * *}$ & $0.281^{* * *}$ \\
\hline & $(4.91)$ & $(5.44)$ & $(5.66)$ \\
\hline \multirow[t]{2}{*}{ Profit prior year } & -0.020 & -0.014 & -0.009 \\
\hline & $(-0.72)$ & $(-0.56)$ & $(-0.35)$ \\
\hline \multirow[t]{2}{*}{ Country risk } & -0.020 & $0.067^{* * *}$ & $-0.072^{* * *}$ \\
\hline & $(-0.68)$ & $(3.81)$ & $(3.76)$ \\
\hline \multirow[t]{2}{*}{ Unemployment rate } & -0.792 & -0.497 & 0.160 \\
\hline & $(-1.26)$ & $(-1.02)$ & $(0.30)$ \\
\hline \multirow[t]{2}{*}{ Hourly wages } & $-0.016^{* * *}$ & $-0.010^{* * *}$ & $-0.012^{* * *}$ \\
\hline & $(-3.88)$ & $(-2.71)$ & $(-3.10)$ \\
\hline \multirow[t]{2}{*}{ Inflation } & $0.778^{*}$ & 0.295 & 0.324 \\
\hline & $(1.84)$ & $(0.82)$ & $(0.82)$ \\
\hline \multirow[t]{2}{*}{ Treasury rate } & $-6.693^{* * *}$ & $-4.037^{* *}$ & $-7.119^{* * *}$ \\
\hline & $(-3.18)$ & $(-2.18)$ & $(-3.50)$ \\
\hline \multirow[t]{2}{*}{ Market size } & $-0.415^{* * *}$ & $-0.252^{* * *}$ & $-0.350 * * *$ \\
\hline & $(-7.81)$ & $(-5.89)$ & $(-7.36)$ \\
\hline \multirow[t]{2}{*}{ GDP growth } & $1.852^{*}$ & $1.962^{* *}$ & $2.493^{* * *}$ \\
\hline & $(1.77)$ & $(2.32)$ & $(2.69)$ \\
\hline Ln(GDP per capita) & 0.042 & $0.041^{*}$ & $0.080^{* * *}$ \\
\hline & $(1.55)$ & $(1.76)$ & $(3.15)$ \\
\hline EU 10 & $0.857^{* * *}$ & $0.665^{* * *}$ & $0.914^{* * *}$ \\
\hline & $(5.54)$ & $(4.90)$ & $(6.07)$ \\
\hline Eurozone & 0.004 & 0.075 & $0.096^{*}$ \\
\hline & $(0.05)$ & $(1.45)$ & $(1.69)$ \\
\hline Constant & $-10.409^{* * *}$ & $-4.954^{* * *}$ & $-6.723^{* * *}$ \\
\hline & $(-5.47)$ & $(-3.23)$ & $(-3.96)$ \\
\hline $\mathrm{R}^{2}$ & 0.043 & 0.035 & 0.045 \\
\hline
\end{tabular}

The table shows the linear regression results for firm investment behavior, estimated over the period from 1998 to 2007. The sample includes only companies that do not have tax loss carry-forwards (number of observations $=107,033$ ). The dependent variables are different (gross) investment rates, as defined in Section E.4.2. See Table E.11 for a description of the dependent and independent variables. Industry, year and industry-year indicator variables are included in all three specifications but are not reported. Standard errors allow for heteroskedasticity and are clustered by firm; t-values are shown in parentheses. ${ }^{*},{ }^{* *}$ and ${ }^{* * *}$ indicate statistical significance at the ten-, five- and one-percent level, respectively. The p-value associated with the F-test for the null hypothesis that all coefficients are equal to zero is zero in all three specifications. 
Table E.5: Economic impact of a difference in the present value of depreciation allowances for machinery of 2.390 percentage points

\begin{tabular}{llrrrrrr}
\hline & & \multicolumn{2}{c}{ Inv. rate 1 } & \multicolumn{2}{c}{ Inv. rate 2 } & \multicolumn{2}{c}{ Inv. rate 3 } \\
& Company size & small & large & small & large & small & large \\
\hline$(1)$ & $\Delta$ PVDA machinery & 2.390 & 2.390 & 2.390 & 2.390 & 2.390 & 2.390 \\
$(2)$ & Coefficient PVDA machinery & 0.147 & 0.147 & 0.097 & 0.097 & 0.135 & 0.135 \\
$(3)$ & Coefficient interaction term & -0.017 & -0.017 & -0.011 & -0.011 & -0.015 & -0.015 \\
$(4)$ & Mean ln(total assets $)_{t-1}$ & 4.880 & 7.882 & 4.880 & 7.882 & 4.880 & 7.882 \\
$(5)$ & Mean investment rate & 0.850 & 0.649 & 0.512 & 0.390 & 0.866 & 0.650 \\
$(6)$ & Mean denominator in T€ & 60 & 9,731 & 53 & 9,445 & 60 & 9,731 \\
\hline$(7)$ & Main effect $(1)^{*}(2)$ & 0.351 & 0.351 & 0.232 & 0.232 & 0.323 & 0.323 \\
$(8)$ & Interaction effect $(1)^{*}(3)^{*}(4)$ & -0.198 & -0.320 & -0.128 & -0.207 & -0.175 & -0.283 \\
$(9)$ & $\Delta$ Investment rate $(7)+(8)$ & 0.153 & 0.031 & 0.104 & 0.025 & 0.148 & 0.040 \\
$(10)$ & $\Delta$ Investment rate in \% $(9) /(5)$ & 18.000 & 4.739 & 20.313 & 6.354 & 17.090 & 6.220 \\
$(11)$ & $\Delta$ Investment in T€ $(9)^{*}(6)$ & 9 & 302 & 5 & 236 & 9 & 389 \\
\hline
\end{tabular}

The table shows the estimated economic impact of a difference in the present value of depreciation allowances for machinery of 2.390 percentage points. This is, for example, the case if the useful life of an asset is seven years and declining-balance depreciation is applied at a rate of 20 percent in one country and at a rate of 30 percent in another country. Mean denominator in $T €$ refers to the denominator of the respective investment rate; that is, the sum of tangible and intangible fixed assets in the case of investment rate 1 and 3 and tangible fixed assets in the case of investment rate 2 .

depreciation of 10 percentage points (and a useful life of seven years) would lead to an average increase in the investment ratios of between 20.31 percent (for small companies) and 4.74 percent (for large companies) in the cross-section. This corresponds to an average increase of investment of between 5.000 (for small companies) and 389.000 euro (for large companies).

Two circumstances have to be kept in mind when interpreting economic effects in this setting. First, the percentage changes in the investment rates appear to be quite high. However, it has to be considered that the sample consists of many very small companies that have only a small amount of assets. For these companies, small investments in terms of the amount in euro may lead to large percentage changes in the investment rate. Second, the underlying data sample has to be considered. Because the analyzed period is only ten years and differences between the present values of depreciation allowances change not only at the beginning of the data period but also during the ten years, it is not possible to distinguish between the temporary and the permanent impact of tax depreciation on investment. Therefore, it is possible that the estimated effects are strongest around the change in depreciation regulations and that they decrease over time. 


\subsection{Panel data analyses}

The second set of regression analyses shows the impact of tax depreciation on investment over time rather than in the cross-section. As pointed out above, to estimate investment effects over time, I separately include country- and firm-specific fixed effects in Equation E.17, which is estimated by ordinary least squares. Similar to the above analyses, all specifications include industry and year indicator variables as well as the interaction between the two. As noted above, however, the industry indicator variables drop out of the equation when firm fixed effects are included because of perfect collinearity. The standard errors that are used allow for heteroskedasticity and are clustered by firm; t-values are shown in parentheses. As described in Section E.5, a different data sample is applied for the analysis of depreciation effects over time, and only companies that do not have tax loss carry-forwards are taken into account.

The regression results of the analysis including country fixed effects are shown in Table E.6. It becomes apparent that the results are very similar to the pooled cross-section results presented in Table E.4, except for the coefficient of the tax rate, which is no longer significant. However, this result is not contradictory to Neoclassical Theory, in which the impact of the tax rate on investment is shown to be ambiguous.

The main effects of the three present values of depreciation allowances are, like in the analysis without country fixed effects, significantly positive but somewhat smaller than those presented in Table E.4. Again, the interaction terms between the present values of depreciation allowances and the logarithm of the previous year's total assets are significantly negative, indicating that small firms react to changes in depreciation allowances more strongly than large corporations.

The coefficients of the size, cash flow, leverage and average tangibility variables are all significant at the one-percent level and point in the same direction as those in the pooled cross-section analysis. However, the absolute values of the coefficients are smaller when country fixed effects are included. The coefficient of the year of incorporation indicator variable is again positive and significant but larger, indicating that corporations invest more when they are in their first three years after incorporation. With regard to the country-specific control variables, there is a significant positive effect of inflation, indicating that inflation favors real investments compared with investments in the capital market. The effect of the treasury rate is significantly negative, as derived by economic theory. Except for GDP growth, which is, as expected, significantly positively associated with investment, the remaining control variables do not seem to have an effect on investment behavior and are either only weakly significant or not significant. 
Table E.6: Panel data estimates with country fixed effects

\begin{tabular}{|c|c|c|c|}
\hline Variable & Investment rate 1 & Investment rate 2 & Investment rate 3 \\
\hline \multirow[t]{2}{*}{ Tax rate } & 0.209 & 0.115 & 0.039 \\
\hline & $(0.55)$ & $(0.34)$ & $(0.11)$ \\
\hline \multirow[t]{2}{*}{ Pvda machinery } & $0.110^{* * *}$ & $0.057 * * *$ & $0.101^{* * *}$ \\
\hline & $(6.56)$ & $(4.07)$ & $(6.45)$ \\
\hline \multirow[t]{2}{*}{ Pvda mach. $* \ln (\text { total assets })_{t-1}$} & $-0.013^{* * *}$ & $-0.007 * * *$ & $-0.012^{* * *}$ \\
\hline & $(-7.22)$ & $(-4.65)$ & $(-7.16)$ \\
\hline \multirow[t]{2}{*}{ Pvda buildings } & $0.019 * * *$ & $0.011^{* *}$ & $0.019 * * *$ \\
\hline & $(3.38)$ & $(2.29)$ & $(3.47)$ \\
\hline \multirow[t]{2}{*}{ Pvda buil. $* \ln (\text { total assets })_{t-1}$} & $-0.003^{* * *}$ & $-0.002^{* * *}$ & $-0.003^{* * *}$ \\
\hline & $(-4.25)$ & $(-3.27)$ & $(-4.66)$ \\
\hline \multirow[t]{2}{*}{ Pvda patents } & $0.025^{* * *}$ & & \\
\hline & $(2.74)$ & & \\
\hline \multirow[t]{2}{*}{ Pvda pat. $* \ln (\text { total assets })_{t-1}$} & $-0.002^{* *}$ & & \\
\hline & $(-2.14)$ & & \\
\hline \multirow[t]{2}{*}{$\operatorname{Ln}(\text { total assets })_{t-1}$} & $1.376^{* * *}$ & $0.668^{* * *}$ & $1.136^{* * *}$ \\
\hline & $(7.25)$ & $(4.69)$ & $(7.13)$ \\
\hline \multirow[t]{2}{*}{ Scaled cash flow } & $0.606^{* * *}$ & $0.469^{* * *}$ & $0.596^{* * *}$ \\
\hline & $(3.93)$ & $(4.11)$ & $(4.02)$ \\
\hline \multirow[t]{2}{*}{ Scaled cash flow $t-1$} & $0.132^{*}$ & $0.105^{*}$ & $0.131^{*}$ \\
\hline & $(1.89)$ & $(1.81)$ & $(1.87)$ \\
\hline \multirow[t]{2}{*}{ Leverage $_{t-1}$} & $0.101^{* * *}$ & $0.092^{* * *}$ & $0.108^{* * *}$ \\
\hline & $(2.81)$ & $(3.06)$ & $(3.17)$ \\
\hline \multirow[t]{2}{*}{ Average tangibility } & $-0.891^{* * *}$ & $-0.382^{* * *}$ & $-0.845^{* * *}$ \\
\hline & $(-30.09)$ & $(-14.66)$ & $(-28.84)$ \\
\hline \multirow[t]{2}{*}{ Year of incorporation } & $0.372^{* * *}$ & $0.311^{* * *}$ & $0.377^{* * * *}$ \\
\hline & $(4.44)$ & $(4.47)$ & $(4.80)$ \\
\hline \multirow[t]{2}{*}{ Profit prior year } & 0.001 & 0.016 & 0.014 \\
\hline & $(0.03)$ & $(0.73)$ & $(0.52)$ \\
\hline \multirow[t]{2}{*}{ Country risk } & -0.017 & -0.012 & -0.020 \\
\hline & $(-0.38)$ & $(-0.30)$ & $(-0.46)$ \\
\hline \multirow[t]{2}{*}{ Unemployment rate } & -0.578 & 0.473 & 0.027 \\
\hline & $(-0.68)$ & $(0.65)$ & $(0.03)$ \\
\hline \multirow[t]{2}{*}{ Hourly wages } & $-0.019 * *$ & -0.011 & -0.013 \\
\hline & $(-2.01)$ & $(-1.39)$ & $(-1.49)$ \\
\hline \multirow[t]{2}{*}{ Inflation } & $1.422^{* * *}$ & $1.659 * * *$ & $1.685^{* * *}$ \\
\hline & $(3.02)$ & $(3.96)$ & $(3.68)$ \\
\hline \multirow[t]{2}{*}{ Treasury rate } & $-7.025^{* * *}$ & $-8.489 * * *$ & $-8.381 * * *$ \\
\hline & $(-3.30)$ & $(-4.52)$ & $(-4.09)$ \\
\hline \multirow[t]{2}{*}{ Market size } & -2.369 & $-3.669 * *$ & $-4.253^{* *}$ \\
\hline & $(-1.32)$ & $(-2.47)$ & $(-2.59)$ \\
\hline \multirow[t]{2}{*}{ GDP growth } & $2.240^{* *}$ & $2.191^{* * *}$ & $2.341^{* * *}$ \\
\hline & $(2.51)$ & $(3.09)$ & $(2.99)$ \\
\hline \multirow[t]{2}{*}{ Ln(GDP per capita) } & $-0.981^{*}$ & $-1.118^{* *}$ & $-1.187^{* *}$ \\
\hline & $(-1.72)$ & $(-2.28)$ & $(-2.17)$ \\
\hline EU 10 & 6.451 & $9.286^{* * *}$ & $10.642^{* * *}$ \\
\hline & $(1.53)$ & $(2.66)$ & $(2.75)$ \\
\hline Constant & 34.559 & $62.852^{* *}$ & $69.156^{* *}$ \\
\hline & $(1.08)$ & $(2.38)$ & $(2.37)$ \\
\hline Number of observations & 131,967 & 131,967 & 131,967 \\
\hline $\mathrm{R}^{2}$ & 0.035 & 0.026 & 0.036 \\
\hline
\end{tabular}

The table shows the linear regression results for firm investment behavior, estimated over the period from 1998 to 2007. The sample includes only companies that do not have tax loss carry-forwards. The dependent variables are different (gross) investment rates, as defined in Section E.4.2. See Table E.11 for a description of the dependent and independent variables. Industry, year, industry-year and country indicator variables are included in all three specifications but are not reported. Standard errors allow for heteroskedasticity and are clustered by firm; t-values are shown in parentheses. ${ }^{*}, *$ and $* * *$ indicate statistical significance at the ten-, five- and one-percent level, respectively. The p-value associated with the F-test for the null hypothesis that all coefficients are equal to zero is zero in all three specifications. 
The regression results of the analysis including firm fixed effects are presented in Table E.7. The first line shows, as in the cross-section analysis, a negative effect of the tax rate on investment. However, the effect is not significant for investment rate 1 and only weakly significant for investment rates 2 and 3. Table E.7 also shows that the results with regard to the impact of tax depreciation in investment do only hold with respect to machinery and patents. For both asset types, the coefficients in Table E.7 confirm a positive impact of tax depreciation on investment that decreases with firm size. Compared with the results presented in Tables E.4 and E.6, the results with regard to machinery are, however, weaker in terms of statistical significance. The results concerning the tax depreciation of buildings do not hold when firm fixed effects are included. None of the coefficients is statistically significant at any conventional level, except for the main effect in the second equation, which is significantly negative at the ten-percent level. Even though theory suggests that a significant positive relation exists between tax depreciation and investment for buildings, these results are not very surprising. In contrast to the planning process for machinery, the planning processes underlying the investment in structures are much more complex, and buildings are, on average, more expensive than machinery. Thus, investments in structures are less flexible than investments in machinery, and firms are therefore less able to adjust their investment behavior in response to changes in depreciation regulations. In addition, when investing in buildings, it is necessary to acquire the land on which the structures are built. Because land is generally not depreciable, the actual present value of depreciation allowances (i.e., the investment incentive) for buildings is effectively lower than the present value applied in the regression analysis. Moreover, the missing effect may be attributable to predominance of small companies in the sample (see Table E.1), which most likely do not own buildings.

With regard to the control variables, there are some differences compared with the preceding analyses that are worth noting. First, not only cash flow but also lagged cash flow seems to be significantly positively associated with investment behavior. In addition, lagged leverage now has the expected significant negative coefficient, and the coefficient of profit prior year is significantly positive, also as expected. However, the coefficient of the year of incorporation indicator variable is not significant in this analysis, indicating that this effect is already captured by the firm-specific fixed effects. In general, this analysis reveals that there are important unobserved time-fixed firm effects that should be considered when estimating the impact of tax depreciation on investment.

With regard to economic significance, the same procedure that is described in Section E.6.1 is applied. Table E.8 shows the economic investment effects of tax depreciation over time, based on 
Table E.7: Panel data estimates with firm fixed effects

\begin{tabular}{|c|c|c|c|}
\hline Variable & Investment rate 1 & Investment rate 2 & Investment rate 3 \\
\hline \multirow[t]{2}{*}{ Tax rate } & -0.553 & $-0.748^{*}$ & $-0.823^{*}$ \\
\hline & $(-1.10)$ & $(-1.80)$ & $(-1.79)$ \\
\hline \multirow[t]{2}{*}{ Pvda machinery } & $0.074^{* *}$ & $0.049^{*}$ & $0.059^{*}$ \\
\hline & $(2.23)$ & $(1.70)$ & $(1.92)$ \\
\hline \multirow[t]{2}{*}{ Pvda mach. $* \ln (\text { total assets })_{t-1}$} & $-0.009 * *$ & $-0.006^{*}$ & $-0.007^{*}$ \\
\hline & $(-2.25)$ & $(-1.77)$ & $(-1.85)$ \\
\hline \multirow[t]{2}{*}{ Pvda buildings } & 0.007 & $-0.018^{*}$ & -0.007 \\
\hline & $(0.57)$ & $(-1.65)$ & $(-0.59)$ \\
\hline \multirow{2}{*}{ Pvda buil. $* \ln (\text { total assets })_{t-1}$} & -0.001 & 0.003 & 0.001 \\
\hline & $(-0.60)$ & $(1.55)$ & $(0.43)$ \\
\hline \multirow[t]{2}{*}{ Pvda patents } & $0.091^{* * *}$ & & \\
\hline & $(3.32)$ & & \\
\hline \multirow[t]{2}{*}{ Pvda pat. $* \ln (\text { total assets })_{t-1}$} & $-0.011^{* * *}$ & & \\
\hline & $(-3.32)$ & & \\
\hline \multirow[t]{2}{*}{$\operatorname{Ln}(\text { total assets })_{t-1}$} & $0.924^{* *}$ & -0.321 & -0.235 \\
\hline & $(2.20)$ & $(-1.05)$ & $(-0.70)$ \\
\hline \multirow[t]{2}{*}{ Scaled cash flow } & $0.548^{* * *}$ & $0.433^{* * *}$ & $0.546^{* * *}$ \\
\hline & $(3.38)$ & $(3.60)$ & $(3.49)$ \\
\hline \multirow{2}{*}{ Scaled cash flow ${ }_{t-1}$} & $0.143^{* *}$ & $0.121^{* *}$ & $0.141^{* *}$ \\
\hline & $(2.25)$ & $(2.36)$ & $(2.22)$ \\
\hline \multirow[t]{2}{*}{ Leverage $_{t-1}$} & $-0.394^{* * *}$ & $-0.367^{* * *}$ & $-0.430^{* * *}$ \\
\hline & $(-4.24)$ & $(-4.76)$ & $(-5.14)$ \\
\hline \multirow[t]{2}{*}{ Year of incorporation } & -0.021 & -0.043 & -0.028 \\
\hline & $(-0.22)$ & $(-0.53)$ & $(-0.31)$ \\
\hline \multirow[t]{2}{*}{ Profit prior year } & $0.123^{* * *}$ & $0.121^{* * *}$ & $0.132^{* * *}$ \\
\hline & $(3.78)$ & $(4.45)$ & $(4.37)$ \\
\hline \multirow[t]{2}{*}{ Country risk } & 0.039 & $0.079 *$ & $0.080^{*}$ \\
\hline & $(0.81)$ & $(1.79)$ & $(1.65)$ \\
\hline \multirow[t]{2}{*}{ Unemployment rate } & -0.727 & 0.316 & -0.468 \\
\hline & $(-0.79)$ & $(0.39)$ & $(-0.53)$ \\
\hline \multirow[t]{2}{*}{ Hourly wages } & -0.003 & 0.003 & 0.000 \\
\hline & $(-0.26)$ & $(0.36)$ & $(0.05)$ \\
\hline \multirow[t]{2}{*}{ Inflation } & -0.153 & -0.023 & -0.105 \\
\hline & $(-0.30)$ & $(-0.05)$ & $(-0.21)$ \\
\hline \multirow[t]{2}{*}{ Treasury rate } & $-7.089^{* * *}$ & $-8.898^{* * *}$ & $-8.676^{* * *}$ \\
\hline & $(-2.98)$ & $(-4.21)$ & $(-3.77)$ \\
\hline \multirow[t]{2}{*}{ Market size } & -1.431 & $-3.370^{*}$ & -3.139 \\
\hline & $(-0.67)$ & $(-1.88)$ & $(-1.60)$ \\
\hline \multirow[t]{2}{*}{ GDP growth } & -1.118 & $-2.290 * * *$ & $-2.351^{* *}$ \\
\hline & $(-1.12)$ & $(-2.75)$ & $(-2.55)$ \\
\hline \multirow[t]{2}{*}{ Ln(GDP per capita) } & 0.663 & 0.475 & 0.639 \\
\hline & $(1.03)$ & $(0.85)$ & $(1.03)$ \\
\hline \multirow[t]{2}{*}{ Constant } & 9.684 & 54.049 & 47.917 \\
\hline & $(0.24)$ & $(1.59)$ & $(1.28)$ \\
\hline Industry-year fixed effects & Yes & Yes & Yes \\
\hline Firm fixed effects & Yes & Yes & Yes \\
\hline Number of observations & 131,967 & 131,967 & 131,967 \\
\hline Within $\mathrm{R}^{2}$ & 0.031 & 0.028 & 0.031 \\
\hline Prob $>F$ & 0.000 & 0.000 & 0.000 \\
\hline
\end{tabular}

The table shows the linear regression results for firm investment behavior, estimated over the period from 1998 to 2007. The sample includes only companies that do not have tax loss carry-forwards. The dependent variables are different (gross) investment rates, as defined in Section E.4.2. See Table E.11 for a description of the dependent and independent variables. Year, industry-year and firm indicator variables are included in all three specifications but are not reported. Standard errors allow for heteroskedasticity and are clustered by firm; t-values are shown in parentheses. ${ }^{*}, * *$ and ${ }^{* * *}$ indicate statistical significance at the ten-, five- and one-percent level, respectively. Prob $>\mathrm{F}$ is the p-value associated with the F-test for the null hypothesis that all coefficients are equal to zero. 
the specification that includes firm fixed effects. ${ }^{25}$ While the average percentage changes in the investment rates lie between 0.74 and 10.06 percent, the corresponding average changes in euro are between 4.000 and 59.000 euro per company. Nevertheless, as discussed in Section E.6.1, the research design does not allow for permanent effects to be differentiated from temporary effects, and the percentage changes of the investment rates have to be interpreted against the background that the sample consists of many very small corporations.

Table E.8: Economic impact of an increase of declining-balance depreciation from 20 to 30 percent based on a panel regression analysis including firm fixed effects

\begin{tabular}{|c|c|c|c|c|c|c|c|}
\hline & \multirow[b]{2}{*}{ Company size } & \multicolumn{2}{|c|}{ Inv. rate 1} & \multicolumn{2}{|c|}{ Inv. rate 2} & \multicolumn{2}{|c|}{ Inv. rate 3} \\
\hline & & small & large & small & large & small & large \\
\hline (1) & $\Delta \mathrm{PVDA}$ machinery & 2.390 & 2.390 & 2.390 & 2.390 & 2.390 & 2.390 \\
\hline$(2)$ & Coefficient PVDA machinery & 0.074 & 0.074 & 0.049 & 0.049 & 0.059 & 0.059 \\
\hline$(3)$ & Coefficient interaction term & -0.009 & -0.009 & -0.006 & -0.006 & -0.007 & -0.007 \\
\hline (4) & Mean $\ln (\text { total assets })_{t-1}$ & 4.865 & 8.046 & 4.865 & 8.046 & 4.865 & 8.046 \\
\hline$(5)$ & Mean investment rate & 0.763 & 0.541 & 0.467 & 0.308 & 0.774 & 0.542 \\
\hline (6) & Mean denominator in $\mathrm{T} €$ & 85 & 9,815 & 77 & 9,460 & 85 & 9,815 \\
\hline (7) & Main effect $(1)^{*}(2)$ & 0.177 & 0.177 & 0.117 & 0.117 & 0.141 & 0.141 \\
\hline$(8)$ & Interaction effect $(1)^{*}(3)^{*}(4)$ & -0.105 & -0.173 & -0.070 & -0.115 & -0.081 & -0.135 \\
\hline (9) & $\Delta$ Investment rate $(7)+(8)$ & 0.072 & 0.004 & 0.047 & 0.003 & 0.060 & 0.006 \\
\hline$(10)$ & $\Delta$ Investment rate in $\%(9) /(5)$ & 9.436 & 0.739 & 10.064 & 0.974 & 7.752 & 1.107 \\
\hline (11) & $\Delta$ Investment in $\mathrm{T} €(9)^{*}(6)$ & 6 & 39 & 4 & 28 & 5 & 59 \\
\hline
\end{tabular}

The table shows the estimated economic impact of an increase in the present value of depreciation allowances for machinery by 2.390 percentage points. This was the case in Germany from 2005 to 2006 when declining-balance depreciation was increased from 20 to 30 percent. Mean denominator in $T €$ refers to the denominator of the respective investment rate; that is, the sum of tangible and intangible fixed assets in the case of investment rate 1 and 3 and tangible fixed assets in the case of investment rate 3.

\subsection{Robustness checks}

\subsubsection{Dynamic specification}

In addition to fixed effects models, the impact of tax depreciation on investment over time can also be estimated by applying a dynamic specification (as, for example, in Dreßler \& Overesch, 2013), which has the advantage of taking adjustment costs into consideration, as explained in detail below. The key feature of dynamic panel data models is the inclusion of the lagged dependent variable as an explanatory variable, i. e., the dependent variable is explained (among others) by its value in the prior year. Because the number of years in the dataset is relatively small, both the ordinary least squares and the fixed effects estimator are biased when a lagged

\footnotetext{
${ }^{25}$ As expected, the economic effects based on the estimation including country fixed effects lie (except for the effects of investment rate 2) between the effects in the cross-section and the effects over time with firm fixed effects.
} 
dependent variable is included on the right-hand side of the equation (a detailed description of why this is the case can be found in the Appendix in Section E.8.5.1), and the Generalized Method of Moments (GMM) estimator is therefore often applied in the case of small $\mathrm{T}$ and large N samples. GMM was developed by Hansen, 1982, and both difference GMM (Arellano \& Bond, 1991) and system GMM (Arellano \& Bover, 1995; Blundell \& Bond, 1998), also known as two-step GMM estimators, are widely used estimators. In a first step, the regression equation is transformed by first differencing, which eliminates time-invariant firm-specific effects. In a second step, the transformed lagged dependent variable is instrumented with lagged levels because it is otherwise correlated with the error term (see Section E.8.5.2 in the Appendix for a detailed explanation).

On the basis of Dreßler \& Overesch, 2013, the following regression equation is applied:

$$
\begin{aligned}
\ln \left(\text { tangibles }_{i, t}\right) & =\beta_{0}+\beta_{1} \cdot \ln \left(\text { tangibles }_{i, t-1}\right)+\beta_{2} \cdot \text { tax }_{\text {rate }}, t+\beta_{3} \cdot \text { pvda }_{c, t}^{m}+\beta_{4} \cdot \text { pvda }_{c, t}^{b} \\
& +\beta_{5} \cdot \text { pvda }_{c, t}^{p}+\beta_{6} \cdot W_{i / c, t}+\text { year }_{t}+\text { year }_{t} \cdot \text { industry }_{i}+\epsilon_{i, t}
\end{aligned}
$$

As the dependent variable, the logarithm of company i's tangible fixed assets in year $t$ is considered $\left(\ln \left(\right.\right.$ tangibles $\left.\left._{i, t}\right)\right)$. The persistence of tangible fixed assets is accounted for by including the logarithm of lagged tangible fixed assets as explanatory variable $\left(\ln\right.$ (tangibles $\left.\left._{i, t-1}\right)\right)$. All other variables are the same as those in the main specification. The underlying assumption of the dynamic specification is that firms are not able to adjust their capital stock for free and immediately because they face adjustment costs (for example, because production processes are interrupted or because of differences between installed and purchased capital; see Chirinko, 1993). Against this background, the model captures the dynamic effects of the explanatory variables on $\ln \left(\right.$ tangibles $\left._{i, t}\right)$, including the magnitude of adjustment costs by the coefficient of $\ln \left(\right.$ tangibles $\left._{i, t-1}\right)$ (Arellano, 2003). First differencing ensures that the change in tangibles (i. e., investment in tangibles) is the left-hand side variable. It is therefore only possible to explain net instead of gross investment, and hence, only the logarithm of tangibles (instead of tangibles plus intangibles) is used as the dependent variable in this specification. As the predicted variable is in logarithmic form, elasticities and semi-elasticities are estimated, depending on whether the respective explanatory variable appears in logarithmic form.

Table E.9 shows the estimation results for the dynamic regression model with the two-step difference GMM estimator with orthogonal deviations (see Roodman, 2009). The sample is the same as the one for the panel data analysis above and includes only companies that are likely to 
Table E.9: Dynamic panel data model

\begin{tabular}{|c|c|c|}
\hline Variable & Coefficient & Z-value \\
\hline $\operatorname{Ln}(\text { tangibles })_{t-1}$ & $0.556^{* * *}$ & 13.00 \\
\hline Tax rate & -0.031 & -0.10 \\
\hline Pvda machinery & $0.188^{* *}$ & 2.08 \\
\hline Pvda machinery $* \ln (\text { total assets })_{t-1}$ & $-0.023^{* *}$ & -2.07 \\
\hline Pvda buildings & -0.013 & -0.47 \\
\hline Pvda buildings $* \ln (\text { total assets })_{t-1}$ & 0.001 & 0.17 \\
\hline $\operatorname{Ln}(\text { total assets })_{t-1}$ & $2.471^{* * *}$ & 2.68 \\
\hline Scaled cash flow & $0.173^{* * *}$ & 4.02 \\
\hline Scaled cash flow $_{t-1}$ & 0.015 & 1.24 \\
\hline Leverage $_{t-1}$ & $-0.321^{* * *}$ & -3.44 \\
\hline Year of incorporation & -0.003 & -0.07 \\
\hline Profit prior year & -0.026 & -0.82 \\
\hline Country risk & -0.047 & -1.51 \\
\hline Unemployment rate & 0.881 & 0.98 \\
\hline Hourly wages & $-0.012^{* * *}$ & -3.91 \\
\hline Inflation & 0.331 & 0.57 \\
\hline Treasury rate & -1.178 & -1.13 \\
\hline Market size & $-3.002^{* * *}$ & -3.28 \\
\hline GDP growth & 0.067 & 0.08 \\
\hline Ln(GDP per capita) & $-0.917^{* * *}$ & -2.92 \\
\hline Industry-year fixed effects & \multicolumn{2}{|c|}{ Yes } \\
\hline Number of observations & \multicolumn{2}{|c|}{83,170} \\
\hline Number of groups & \multicolumn{2}{|c|}{18,083} \\
\hline Number of instruments & \multicolumn{2}{|c|}{126} \\
\hline Wald test $\left(\right.$ Prob $\left.>\chi_{124 / 126}^{2}\right)$ & \multicolumn{2}{|c|}{0.000} \\
\hline Hansen J test & \multicolumn{2}{|c|}{0.214} \\
\hline Sargan test & \multicolumn{2}{|c|}{0.198} \\
\hline $\operatorname{AR}(1)$ & \multicolumn{2}{|c|}{0.000} \\
\hline $\operatorname{AR}(2)$ & \multicolumn{2}{|c|}{0.405} \\
\hline
\end{tabular}

The dependent variable is $\ln (\text { tangibles })_{t}$. For the definitions of the variables, see Table E.11 in the Appendix. Year-industry and year indicator variables are included in all regressions but are not reported. Results are reported for the two-step difference Generalized Method of Moments estimator with orthogonal deviations. Robust standard errors proposed by Windmeijer, 2005, are applied in all specifications. *, ** and *** indicate significance at the ten-, five- and one-percent level, respectively. The Wald test tests the joint significance of the regression coefficients. $\mathrm{AR}(1)$ and $\mathrm{AR}(2)$ are tests of first-order and second-order autocorrelation. The Hansen $\mathrm{J}$ test and the Sargan test are tests of the over-identifying restrictions for the GMM estimator. For all tests, $\mathrm{p}$-values are reported.

have tax loss carry-forwards. However, the number of observations is smaller because observations are lost owing to the inclusion of lagged variables as explanatory variables and instruments. Year and industry-year indicator variables are included but are not reported. To overcome the problem of endogeneity, the (differenced) lagged dependent variable $\left(\ln \left(\operatorname{tangibles}_{i, t-1}\right)\right)$ is instrumented with its second, third and fourth lag in levels, and the (differenced) size variable $\left(\ln (\text { total assets })_{i, t-1}\right)$ is instrumented with its first lag in levels. Since interaction terms with endogenous variables suffer from endogeneity as well, the (differenced) interaction terms are also 
instrumented with their first lag in levels. ${ }^{26}$

The test statistics at the bottom of Table E.9 indicate that the estimated model is generally valid. The Wald test of joint significance of the estimated parameters rejects the null hypothesis that all parameters are equal to zero. The results of the Hansen J test and those of the Sargan test are also positive because the null hypothesis that the applied instruments are jointly valid cannot be rejected. In addition, the model should be tested for autocorrelation in the idiosyncratic error term since this would make some lags of explanatory variables invalid as instruments. In the case of the difference GMM estimator, first-order autocorrelation in levels is present if second-order correlation in first differences is detected. Because the differenced error terms are correlated by construction, first-order correlation in differences is anticipated, therefore arising no cause for concern. As apparent from the final lines of Table E.9, $\mathrm{AR}(1)$ and $\mathrm{AR}(2)$ tests show the expected results. Whereas first-order autocorrelation is present, the hypothesis of no secondorder autocorrelation is not rejected.

As shown in Table E.9, the results with regard to the present value of depreciation allowances for machinery are confirmed by the dynamic panel data model. That is, the present value of depreciation allowances for machinery is positively associated with investment in tangible fixed assets, and this effect decreases with firm size. However, I do not find any significant effect with regard to the present value of depreciation allowances for buildings.

\subsubsection{Alternative definition of company size}

In addition to the definition of company size applied above, I divide the sample into four different size classes based on average total assets over all years with available data. Size class one contains the smallest companies (i.e., all companies in the first quartile); the largest companies (all companies in the fourth quartile) are in size class four. Size effects are measured by including both the main effects of the size class indicator variables (instead of $\ln \left(\right.$ total assets) $\left.{ }_{t-1}\right)$ and interaction terms with the size class indicator variables and the present values of depreciation allowances in the regression analysis. Based on the results presented above, only companies without tax loss carry-forward are included in the analysis.

The results are presented in Tables E.14 and E.15 in the Appendix. While Tables E.14 and E.15 show only the main variables of interest, the same control variables from the analyses above are included in the regressions. The results generally correspond to the results derived

\footnotetext{
${ }^{26}$ The instrument count of 126 is composed of the six instruments for the endogenous variables and 120 instruments for the exogenous variables (including eight year indicator variables, 96 year-industry indicator variables and 16 additional explanatory variables) that instrument themselves.
} 
above, i.e., there is a positive impact of tax depreciation for machinery on investment that is strongest for small companies. A similar effect can be found for the present value of depreciation allowances for patents. However, this effect disappears when firm fixed effects are included. With regard to the present value of tax depreciation for buildings, the results do not show any clear pattern, which is consistent with the firm fixed effects analysis in which the original definition of company size is applied.

\subsubsection{Estimations based on the full sample}

As described in Section E.5, the preceding estimations are not based on all the available data but on a selected subsample, because some countries are heavily overrepresented in the original dataset. Whereas the cross-section analysis is based on a randomly selected subsample (where every country is approximately equally represented), the panel data analysis is based on those corporations with the most available firm-year observations. To ensure that the estimated effects are present in not only the chosen subsamples but also the whole sample, the estimations in Tables E.4 (pooled cross-section), E.6 (country fixed effects) and E.7 (firm fixed effects) are carried out again, using all the available data.

The estimated regression results are shown in Tables E.16 to E.18 in the Appendix. The coefficients of the present values of depreciation allowances for machinery and patents basically correspond to the results of the analyses of the two subsamples. The present value of depreciation allowances for machinery is, in all specifications, significantly positively associated with investment, and the effect, in almost all specifications, decreases with increasing firm size. The only exception is the regression analysis that includes firm fixed effects where investment rate 3 is the dependent variable. In this case, the main effect of the present value of tax depreciation is significantly positive, and the interaction term has a negative coefficient that is not significant at any conventional level (the t-value is 1.64). With regard to tax depreciation of patents, the main effect has a significant positive coefficient in all specifications. However, a decrease of the effect with increasing firm size can only be identified when firm fixed effects are included in the regression analysis. A positive association of the present value of depreciation allowances and investment that decreases with firm size can also be found with regard to buildings. However, because this effect is not present in the original specification that includes firm fixed effects, this result should be interpreted with caution because the effect is most likely attributable to the composition of the sample. 


\subsubsection{Alternative capital market interest rates}

As pointed out above, the present values of depreciation allowances are, among others, determined by the applied discount rate. In theory, depreciation tax shields are nearly riskless after-tax cash flows and should be discounted at an after-tax interest rate on risk-free assets (Summers, 1987). As exact, company-specific discount rates are not available because of data limitations, a constant interest rate of five percent is applied in the preceding analysis. To test whether the results are robust against different choices of the discount rate, the regressions are estimated again using the country- and year-specific interest rate of ten-year government bonds after corporate taxes as a discount rate to determine the present values of depreciation allowances.

The results are presented in Tables E.19 to E.21 in the Appendix. As shown in these tables, the results are generally robust against different specifications for the discount rate. Applying the country- and year-specific interest rate of ten-year government bonds after taxes as a discount rate (instead of a constant five-percent rate) leads to the same basic conclusions as those drawn from the preceding analyses. In almost all specifications, the present values of depreciation allowances for both machinery and patents are significantly positively associated with investment, and the effect decreases with firm size. However, the results with regard to depreciation of machinery and investment rate 1 are only significant when country indicator variables are included in the regression. In the pooled cross-section regression and in the regression in which firm fixed effects are included, the signs of the coefficients point in the expected direction, but the coefficients are not significant. In line with the conclusions drawn from the preceding analyses concerning the depreciation of buildings, there is no clear evidence of a relation between the present value of depreciation allowances for buildings and investment activity.

\section{Concluding remarks}

The impact of tax policy measures on investment is of crucial importance for policy makers aiming to stimulate economic growth. It is therefore fundamental to know how companies in different situations and with different characteristics respond to changes in tax regulations. Such information is particularly relevant to the current political discussions about the introduction of a Common Consolidated Corporate Tax Base in the European Union. However, although the impact of tax regulations on investment is exceptionally relevant, existing studies on this issue are mainly limited to stock-oriented companies in the United States. In addition, the results of these studies are very diverse, with some studies finding no impact of tax incentives 
on investment and others finding an economically significant effect.

Against this background, I have analyzed the impact of tax depreciation regulations on different investment ratios both across countries and over time. In contrast to existing studies, I have used a panel data set of small, medium-sized and large companies (both publicly and privately held) from nine European countries and have considered tax depreciation by using the present value of depreciation allowances. Based on the country- and year-specific tax depreciation regulations, I have estimated the present values of depreciation allowances for buildings, machinery and patents and employed them as key explanatory variables.

In the first analysis, the effects of tax depreciation were estimated separately for companies that are expected to have and those that are expected not to have tax loss carry-forwards. The results reveal that both the tax rate and tax depreciation do not affect investment activity if companies are very unlikely to pay taxes because they have a tax loss carry-forward. This result is particularly important for policy makers, as it demonstrates that stimulating investment by improving tax depreciation regulations (or lowering the tax rate) is only effective if companies actually pay taxes. In times of crisis, when many companies typically face losses and are, therefore, not required to pay taxes, investment incentives through improved tax depreciation may not be effective. Based on this knowledge, the subsequent analyses have covered only corporations without tax loss carry-forwards.

The results of the pooled cross-section and the panel data analysis for companies without tax loss carry-forwards differ with regard to the different types of assets. Regarding patents, the data generally reveal a positive association between the present value of depreciation allowances and the investment ratio. However, as described above, patents are often internally developed, and it is therefore up to the companies to decide when to complete the development process and thus when to capitalize the developed patents. Therefore, the observed effect may only be attributable to the time of recognition on the balance sheet rather than to the actual time of investment and this result should therefore be interpreted with caution.

With regard to the tax depreciation of machinery, I have found a significantly positive impact of tax depreciation on investment that decreases with increasing firm size. This result relates to the pooled cross-section analysis as well as to the panel data analyses that include country and firm fixed effects. The effect is also measurable when a dynamic specification is applied, and it is robust against different company size definitions, different sample compositions and different capital market interest rates. On the contrary, I have not found clear evidence of a relation between investment and tax depreciation for buildings. 
Considering the current discussion regarding the introduction of a Common Consolidated Corporate Tax Base at EU level, the results indicate that policy makers should focus on tax depreciation regulations for machinery when elaborating possible designs of such a tax base. In addition, the results show that improved tax depreciation for machinery may be an effective measure for policy makers aiming to support small and medium-sized corporations in particular. However, it should be kept in mind that the results with regard to machinery only hold for corporations that are likely to pay taxes. 


\section{Appendix}

\subsection{Neoclassical Theory of investment behavior - mathematical derivations}

Jorgenson, 1965, bases the derivation of the Neoclassical Model of investment behavior on the following Lagrange function (as illustrated in Section E.3):

$$
\begin{aligned}
f(t) & =e^{-r\left(1-\tau_{I}\right) t} \\
& {\left[p(t) Q(t)-l(t) L(t)-q(t) I(t)-\tau(t)\left(p(t) Q(t)-l(t) L(t)-q\left(v(t) \delta+w(t) r-x(t) \frac{\dot{q}}{q}\right) K\right)\right] } \\
& +\lambda_{0}(t) F(Q, L, K)+\lambda_{1}(t)(\dot{K}(t)-I(t)+\delta K(t))
\end{aligned}
$$

The Euler necessary conditions (E.24 to E.27) for the maximum of the present value of the firm and the applicable constraints (E.28 and E.29) are shown below:

$$
\begin{aligned}
\frac{\partial f}{\partial Q}-\frac{d}{d t} \frac{\partial f}{\partial \dot{Q}} & =e^{-r\left(1-\tau_{I}\right) t}(1-\tau(t)) p+\lambda_{0}(t) \frac{\partial F}{\partial Q}=0 \\
\frac{\partial f}{\partial L}-\frac{d}{d t} \frac{\partial f}{\partial \dot{L}} & =-e^{-r\left(1-\tau_{I}\right) t}(1-\tau(t)) l+\lambda_{0}(t) \frac{\partial F}{\partial L}=0 \\
\frac{\partial f}{\partial I}-\frac{d}{d t} \frac{\partial f}{\partial \dot{I}} & =-e^{-r\left(1-\tau_{I}\right) t} q-\lambda_{1}(t)=0 \\
\frac{\partial f}{\partial K}-\frac{d}{d t} \frac{\partial f}{\partial \dot{K}} & =e^{-r\left(1-\tau_{I}\right) t} \tau(t) q\left(v(t) \delta+w(t) r-x(t) \frac{\dot{q}}{q}\right)+\lambda_{0}(t) \frac{\partial F}{\partial K}+\delta \lambda_{1}(t)-\frac{d}{d t} \lambda_{1}(t)=0 \\
\frac{\partial f}{\partial \lambda_{0}} & =F(Q, L, K)=0 \\
\frac{\partial f}{\partial \lambda_{1}} & =\dot{K}-I+\delta K=0
\end{aligned}
$$

Combining Equations E.24 and E.25 leads to the marginal productivity condition for labor services: ${ }^{27}$

$$
\begin{aligned}
& e^{-r\left(1-\tau_{I}\right) t}(1-\tau(t))=-\lambda_{0}(t) \frac{\partial F}{\partial Q} \frac{1}{p} \quad \text { and } \quad e^{-r\left(1-\tau_{I}\right) t}(1-\tau(t))=\lambda_{0}(t) \frac{\partial F}{\partial L} \frac{1}{l} \\
\Leftrightarrow & -\lambda_{0}(t) \frac{\partial F}{\partial Q} \frac{1}{p}=\lambda_{0}(t) \frac{\partial F}{\partial L} \frac{1}{l} \\
\Leftrightarrow & \frac{\partial Q}{\partial L}=\frac{l}{p}
\end{aligned}
$$

\footnotetext{
${ }^{27}$ The marginal product for labor services is positive because $\frac{\partial F}{\partial Q}$ and $\frac{\partial F}{\partial L}$ have different algebraic signs.
} 
To derive the marginal productivity condition for capital services, Equation E.26 is solved for $\lambda_{1}(t)$, and the result is differentiated with respect to t. For simplicity, $\tau(t), v(t), w(t)$ and $x(t)$ are noted as $\tau, v, w$ and $x$ in the following.

$$
\begin{aligned}
\lambda_{1}(t) & =-e^{-r\left(1-\tau_{I}\right) t} q \\
\Leftrightarrow \frac{d}{d t} \lambda_{1}(t) & =\left(r e^{-r\left(1-\tau_{I}\right) t}-r \tau_{I} e^{-r(1-\tau) t}\right) q-e^{-r\left(1-\tau_{I}\right) t} \dot{q}=e^{-r\left(1-\tau_{I}\right) t}\left(r q-r \tau_{I} q-\dot{q}\right)
\end{aligned}
$$

Replacing $\lambda_{1}(t)$ and $\frac{d}{d t} \lambda_{1}(t)$ in Equation E.27 leads to the following result:

$$
\begin{aligned}
& e^{-r\left(1-\tau_{I}\right) t} \tau q\left(v \delta+w r-x \frac{\dot{q}}{q}\right)+\lambda_{0}(t) \frac{\partial F}{\partial K}-\delta e^{-r\left(1-\tau_{I}\right) t} q-e^{-r\left(1-\tau_{I}\right) t}\left(r q-r \tau_{I} q-\dot{q}\right)=0 \\
& \Leftrightarrow \lambda_{0}(t) \frac{\partial F}{\partial K}=-e^{-r\left(1-\tau_{I}\right) t} \tau q\left(v \delta+w r-x \frac{\dot{q}}{q}\right)+e^{-r\left(1-\tau_{I}\right) t}\left(\delta q+r q-r \tau_{I} q-\dot{q}\right) \\
& \Leftrightarrow \lambda_{0}(t) \frac{\partial F}{\partial K}=e^{-r\left(1-\tau_{I}\right) t} q\left[-\tau\left(v \delta+w r-x \frac{\dot{q}}{q}\right)+\delta+r-r \tau_{I}-\frac{\dot{q}}{q}\right] \\
& \Leftrightarrow \lambda_{0}(t) \frac{\partial F}{\partial K}=e^{-r\left(1-\tau_{I}\right) t} q\left[\delta(1-\tau v)+r\left(1-\tau w-\tau_{I}\right)-\frac{\dot{q}}{q}(1-\tau x)\right]
\end{aligned}
$$

Combining this equation with Equation E.24 results in the marginal productivity condition for capital services: ${ }^{28}$

$$
\begin{aligned}
\frac{\partial Q}{\partial K} & =\frac{e^{-r\left(1-\tau_{I}\right) t} q\left[\delta(1-\tau v)+r\left(1-\tau w-\tau_{I}\right)-\frac{\dot{q}}{q}(1-\tau x)\right]}{e^{-r\left(1-\tau_{I}\right) t}(1-\tau) p} \\
\Leftrightarrow & \frac{\partial Q}{\partial K}=\frac{q\left[\delta(1-\tau v)+r\left(1-\tau w-\tau_{I}\right)-\frac{\dot{q}}{q}(1-\tau x)\right]}{(1-\tau) p} \\
\Leftrightarrow & \frac{\partial Q}{\partial K}=\frac{q\left[\delta\left[\frac{1-\tau v}{1-\tau}\right]+r\left[\frac{1-\tau w-\tau_{I}}{1-\tau}\right]-\frac{\dot{q}}{q}\left[\frac{1-\tau x}{1-\tau}\right]\right]}{p}=\frac{c}{p}
\end{aligned}
$$

with:

$$
c=q\left[\delta\left[\frac{1-\tau v}{1-\tau}\right]+r\left[\frac{1-\tau w}{1-\tau}\right]+r\left[\frac{-\tau_{I}}{1-\tau}\right]-\frac{\dot{q}}{q}\left[\frac{1-\tau x}{1-\tau}\right]\right]
$$

\footnotetext{
${ }^{28}$ Again, the marginal product of capital services is positive because $\frac{\partial F}{\partial Q}$ and $\frac{\partial F}{\partial K}$ have different algebraic signs.
} 


\subsection{Data selection process}

Table E.10: Data selection process

\begin{tabular}{|c|c|c|}
\hline & Selection & $\begin{array}{l}\text { Number of } \\
\text { firm-year } \\
\text { observations }\end{array}$ \\
\hline & $\begin{array}{l}\text { Firm-year observations with (any) available data (25 European countries, } \\
\text { excluding Croatia, Cyprus and Slovenia, for } 1994 \text { to 2007) }\end{array}$ & $23,763,554$ \\
\hline- & $\begin{array}{l}\text { Countries without changes in depreciation regulations between } 1998 \text { and } \\
2007 \text { (BE, EE, ES, GR, IT, LV, NL, PT, SE) }\end{array}$ & $11,518,183$ \\
\hline- & Companies other than corporations (partnerships, etc.) & 889,500 \\
\hline- & $\begin{array}{l}\text { Firm-year observations with missing data for industry, assets, depreciation } \\
\text { or other non-current liabilities }\end{array}$ & $3,526,035$ \\
\hline- & Erroneous observations (i. e., total assets $<$ fixed assets, leverage $>1$ ) & 96,067 \\
\hline- & $\begin{array}{l}\text { Firm-year observations of companies with a changing group structure be- } \\
\text { tween } 1994 \text { and } 2007\end{array}$ & 810.682 \\
\hline- & $\begin{array}{l}\text { Firm-year observations in non-euro states for which no exchange rate is } \\
\text { available }\end{array}$ & 40,092 \\
\hline- & $\begin{array}{l}\text { Companies without tangible and intangible fixed assets between } 1994 \text { and } \\
2007\end{array}$ & 128,002 \\
\hline & $\begin{array}{l}\text { Missing data on variables in Table E.2 (including all data from } 1994 \text { to } \\
1997 \text { because of missing data on depreciation regulations during that time) }\end{array}$ & $3,871,838$ \\
\hline$=$ & Original sample (nine European countrie & $2,883,155$ \\
\hline \multicolumn{3}{|c|}{ Pooled cross-section analysis } \\
\hline & $\begin{array}{l}\text { Firm-year observations that have to be deleted because of the random } \\
\text { sampling procedure }\end{array}$ & $2,751,597$ \\
\hline & Random sample (nine European countries, 1998 to 2007) & 131,558 \\
\hline \multicolumn{3}{|c|}{ Panel data analysis } \\
\hline & $\begin{array}{l}\text { Firm-year observations that have to be deleted because of the random } \\
\text { sampling procedure }\end{array}$ & $2,727,577$ \\
\hline & Random sample (nine European countries, 1998 to 2007) & 155,57 \\
\hline
\end{tabular}




\subsection{Definitions of variables}

Table E.11: Variable definitions

\begin{tabular}{|c|c|c|}
\hline Variable & Definition & $\begin{array}{l}\text { Expected } \\
\text { sign }\end{array}$ \\
\hline Investment rate 1 & $\begin{array}{l}\text { Changes in tangibles and intangibles plus depreciation, scaled } \\
\text { by the end-of-prior-year sum of tangibles and intangibles; mea- } \\
\text { sured as a decimal }\end{array}$ & dep. variable \\
\hline Investment rate 2 & $\begin{array}{l}\text { Changes in tangibles, scaled by end-of-prior-year tangibles; } \\
\text { measured as a decimal }\end{array}$ & dep. variable \\
\hline Investment rate 3 & $\begin{array}{l}\text { Changes in tangibles plus depreciation, scaled by end-of-prior- } \\
\text { year tangibles; depreciation of tangibles is estimated as the ratio } \\
\text { of tangibles to the sum of tangibles and intangibles in year t-1 } \\
\text { multiplied by the total amount of depreciation; measured as a } \\
\text { decimal }\end{array}$ & dep. variable \\
\hline Tax rate & Statutory corporate profit tax rate; measured as a decimal & $?$ \\
\hline Pvda machinery & $\begin{array}{l}\text { Present value of depreciation allowances for machinery; mea- } \\
\text { sured in percentage points }\end{array}$ & + \\
\hline Pvda buildings & $\begin{array}{l}\text { Present value of depreciation allowances for buildings; mea- } \\
\text { sured in percentage points }\end{array}$ & + \\
\hline Pvda intangibles & $\begin{array}{l}\text { Present value of depreciation allowances for intangibles; mea- } \\
\text { sured in percentage points }\end{array}$ & + \\
\hline Scaled cash flow & $\begin{array}{l}\left(\text { Profit }_{\text {loss for period }}+\text { depreciation }_{t}+\text { changes in other non- }\right. \\
\left.\text { current liabilities }_{t-(t-1)}\right) / \text { total }_{\text {assets }_{t-1}} ; \text { measured as a deci- } \\
\text { mal }\end{array}$ & + \\
\hline Leverage $_{t-1}$ & $\begin{array}{l}\text { Ratio of debt (non-current and current liabilities) to total as- } \\
\text { sets; measured as a decimal }\end{array}$ & - \\
\hline Ln(total assets $)_{t-1}$ & Logarithm of total assets (measured in 1,000 euro) in year t-1 & + \\
\hline Average tangibility & $\begin{array}{l}\text { Average ratio of tangible and intangible fixed assets to total } \\
\text { assets over all years with available data }\end{array}$ & + \\
\hline $\begin{array}{l}\text { Year of incorpora- } \\
\text { tion }\end{array}$ & $\begin{array}{l}\text { Indicator variable; one if a company is in the first three years } \\
\text { after incorporation and } 0 \text { otherwise }\end{array}$ & + \\
\hline Profit prior year & $\begin{array}{l}\text { Indicator variable; one if a company had an operating profit }> \\
50,000 \text { in the preceding year and } 0 \text { otherwise }\end{array}$ & + \\
\hline Country risk & $\begin{array}{l}\text { Shows the OECD country credit risk and takes values between } \\
\text { zero (low risk) and seven (high risk) }\end{array}$ & - \\
\hline Unemployment rate & Yearly unemployment rate; measured as a decimal & - \\
\hline Hourly wages & Yearly average wages per hour; measured in euro & - \\
\hline Inflation & $\begin{array}{l}\text { Inflation rate based on average consumer prices; measured as a } \\
\text { decimal }\end{array}$ & $?$ \\
\hline Treasury rate & $\begin{array}{l}\text { Government bond yields with a ten-year maturity; measured as } \\
\text { a decimal }\end{array}$ & - \\
\hline Market size & Logarithm of the number of inhabitants & $?$ \\
\hline GDP growth & Yearly growth in gross domestic product; measured as a decimal & + \\
\hline GDP per capita & Gross domestic product per capita; measured in euro & + \\
\hline$E U 10$ & $\begin{array}{l}\text { Indicator variable; one if a company was a member of the EU } \\
10 \text { states and } 0 \text { otherwise }\end{array}$ & + \\
\hline Eurozone & $\begin{array}{l}\text { Indicator variable; one if a company is member of the Eurozone } \\
\text { (i. e., for Germany, Finland and France) and } 0 \text { otherwise }\end{array}$ & + \\
\hline
\end{tabular}




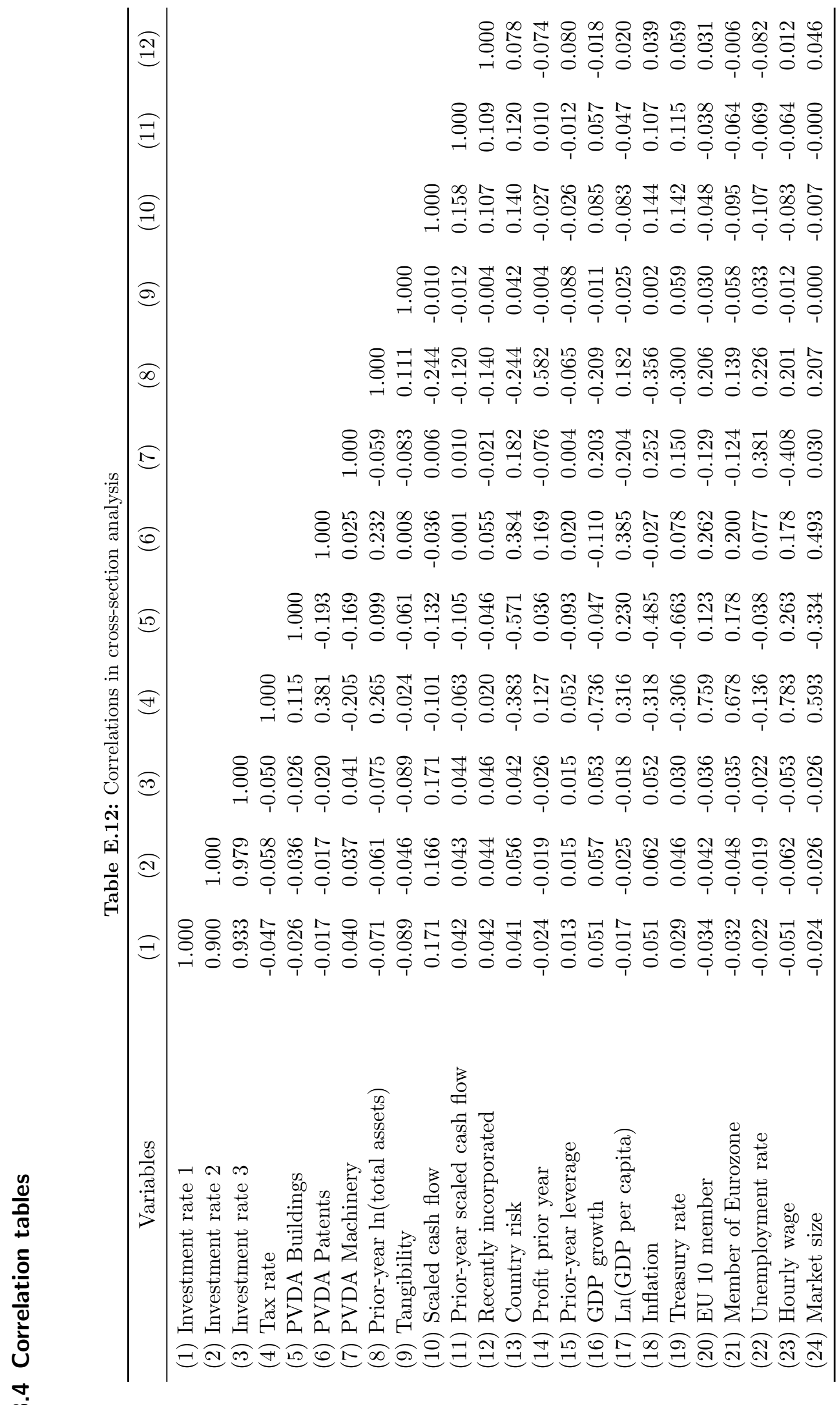




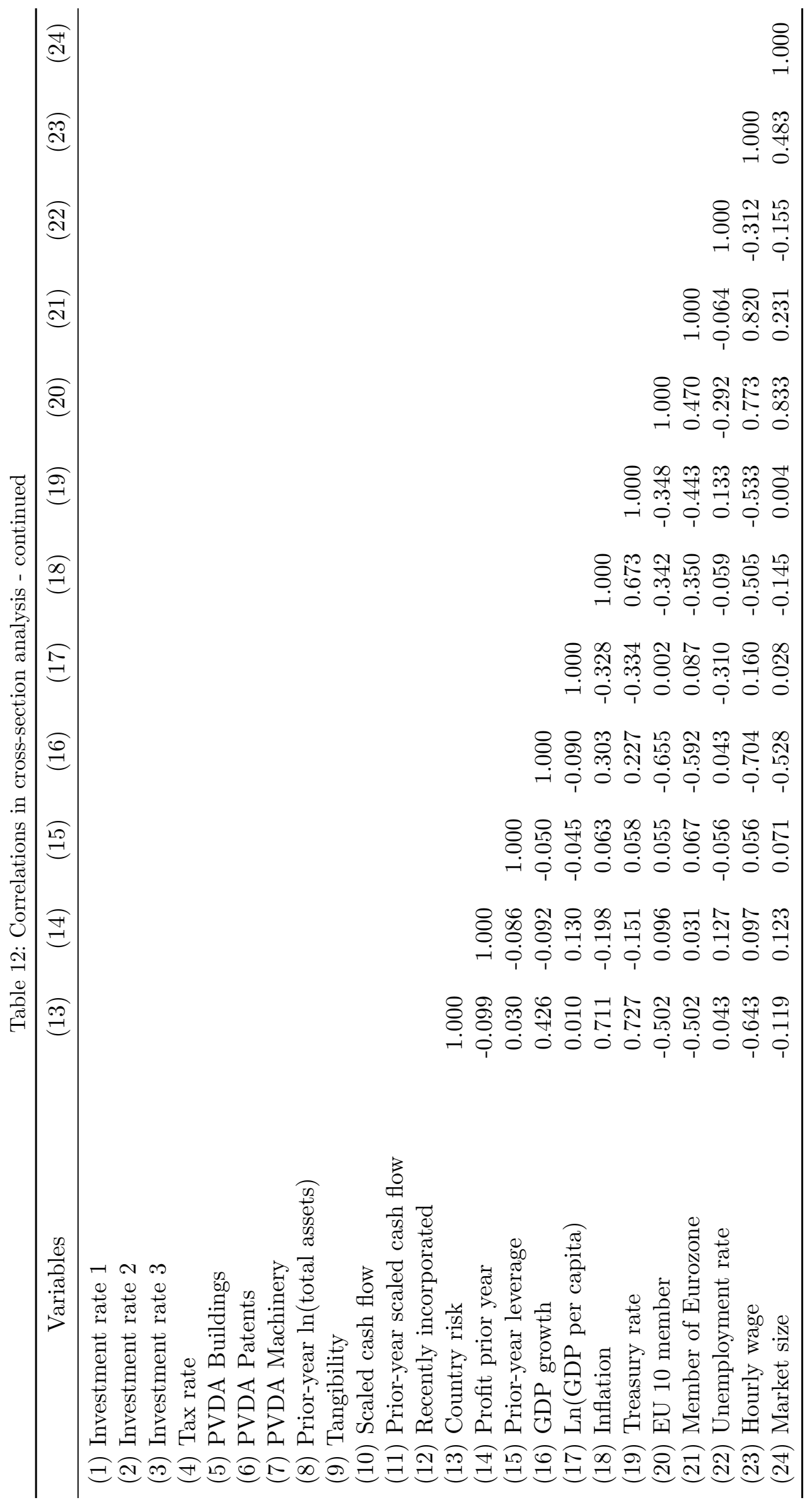




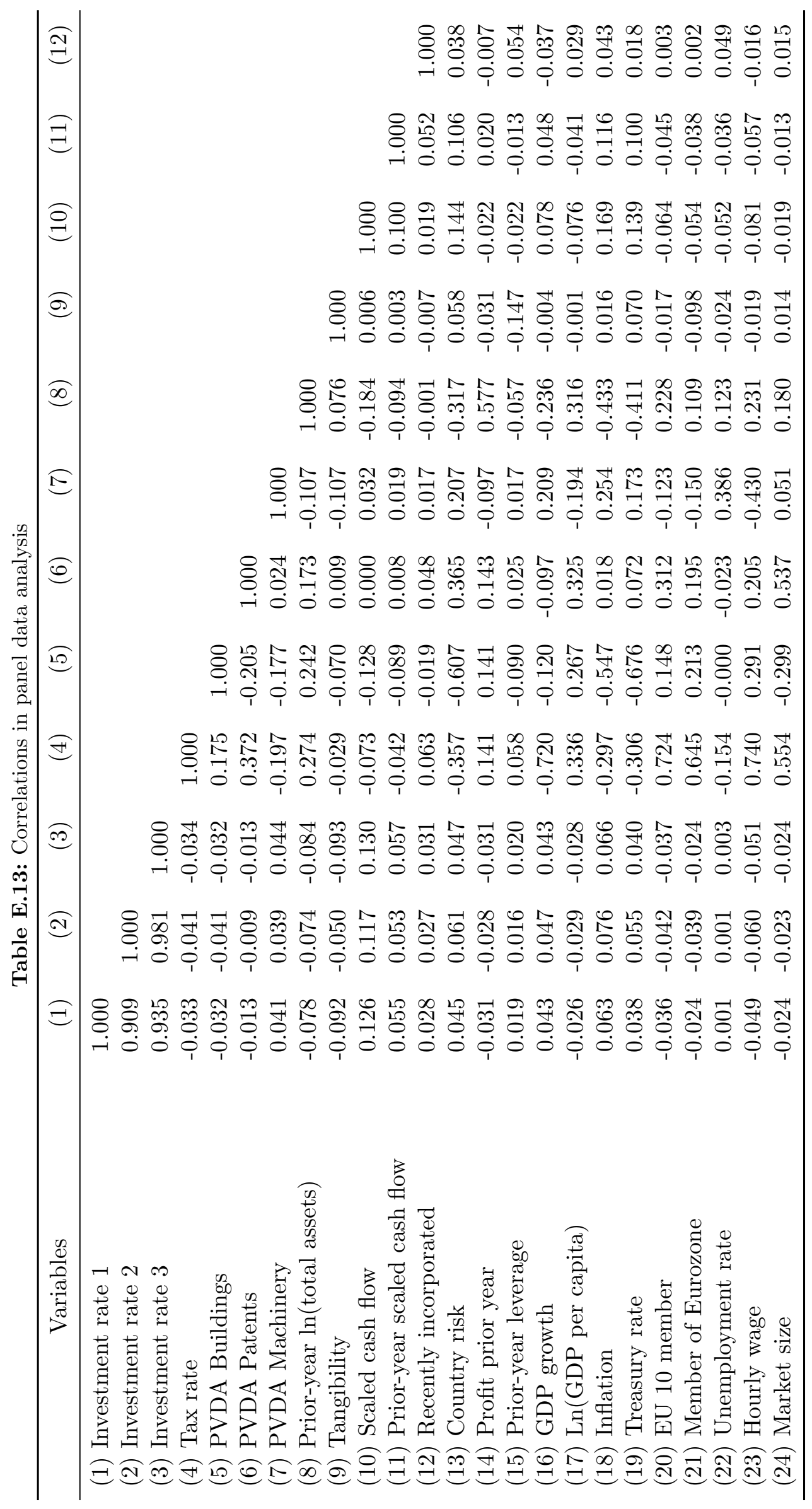




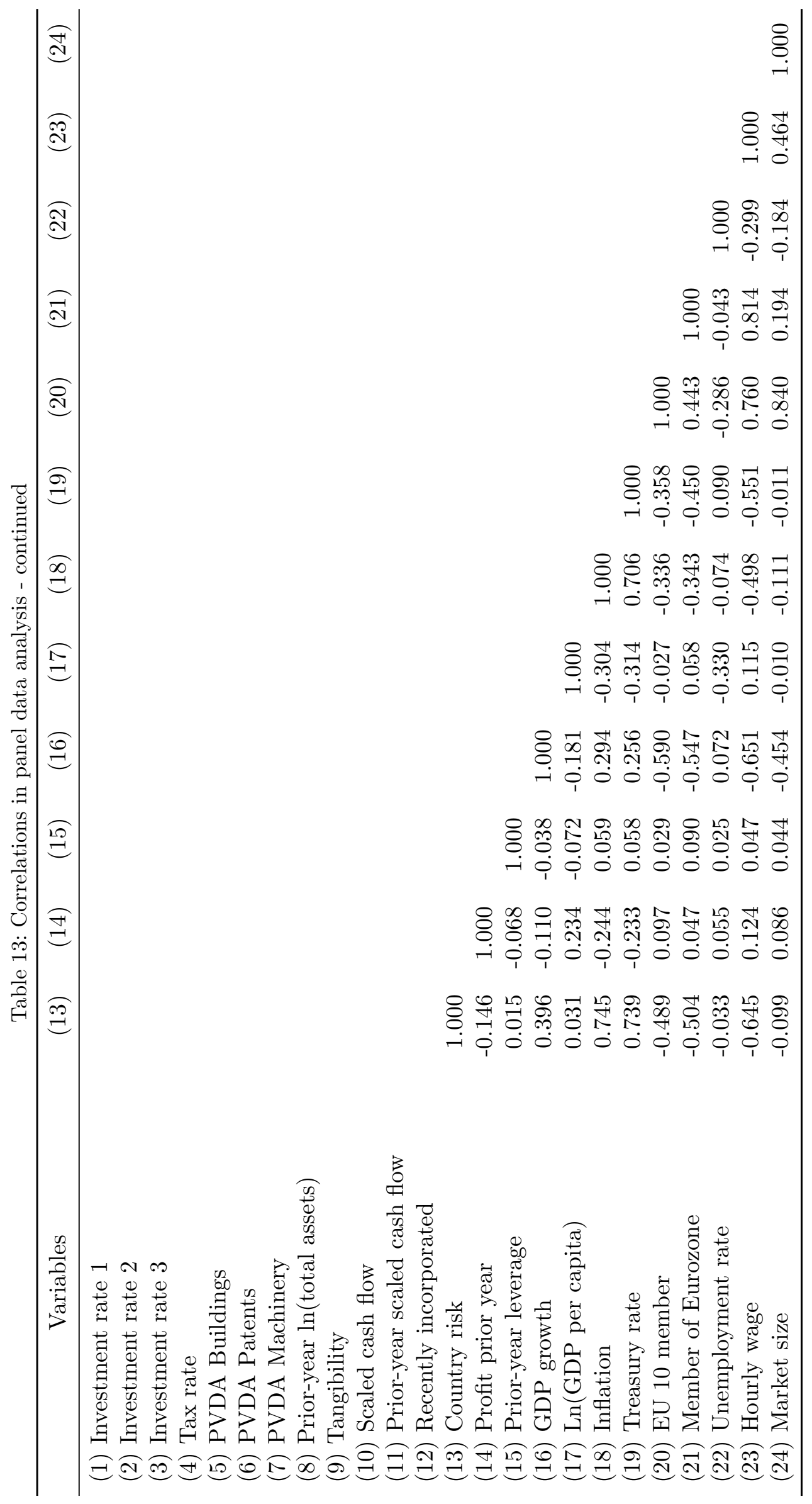




\subsection{Dynamic panel data models}

\subsubsection{Ordinary least squares and within groups estimator}

Equation E.22 in a generalized form appears as follows:

$$
y_{i, t}=\beta_{0}+\beta_{1} y_{i, t-1}+\beta_{2} X_{i, t}+\beta_{3} W_{i, t}+\gamma_{t}+\epsilon_{i, t}
$$

$\gamma_{t}$ represents year-specific effects, and $\epsilon_{i, t}$ is the composite error term with $\epsilon_{i, t}=\delta_{i}+u_{i, t}$, whereby $\delta_{i}$ represents (unobserved) company-specific fixed effects and $u_{i, t}$ is the idiosyncratic error term.

Applying a simple ordinary least squares estimator would ignore company-specific fixed effects and therefore lead to endogeneity through omitted variables. Since $y_{i, t}$ is a function of $\delta_{i}$ and $\delta_{i}$ is time invariant, $y_{i, t-1}$ must be a function of $\delta_{i}$. As a result, the equation suffers from endogeneity $\left(E\left(\epsilon_{i, t} \mid y_{i, t-1}\right) \neq 0\right)$, and the ordinary least squares levels estimator is biased and inconsistent because the correlation between the error term and the lagged dependent variable does not disappear as the number of companies in the sample increases. This problem is known as "dynamic panel bias" (Nickell, 1981), and the implications of such a bias are as follows. If a company experiences a large positive shock in investment in year $\mathrm{t}$ outside the estimated model, the fixed effect for this company (which is the deviation of the company's average investment from the average investment in the sample) will be higher for the whole period under consideration. In year $t+1$, both the fixed effect and the lagged dependent variable will be higher, indicating a positive correlation between the lagged dependent variable and the error. Therefore, predictive power may be attributed to the lagged dependent variable, which, in fact, belongs to the fixed effect. Because the impact of a (positive or negative) shock in a single year on the company's fixed effect decreases with an increasing number of periods considered, the ordinary least squares estimator is (only) consistent if the number of periods is sufficiently large (see also Roodman, 2009).

A common approach to overcome the problem of endogeneity through omitted variables is to transform the data to remove time-invariant company-specific effects. The within groups estimator does this by expressing Equation E.40 as deviations of the variables from their respective mean values. The transformed equation is then estimated by ordinary least squares. Equation E.40 transforms to 


$$
\begin{aligned}
y_{i, t}-\bar{y}_{i .} & =\beta_{0}+\beta_{1}\left(y_{i, t-1}-\bar{y}_{i .}\right)+\beta_{2}\left(X_{i, t}-\bar{X}_{i .}\right) \\
& +\beta_{3}\left(W_{i, t}-\bar{W}_{i .}\right)+\left(\gamma_{t}-\bar{\gamma}_{.}\right)+\left(\delta_{i}-\bar{\delta}_{i}\right)+\left(u_{i, t}-\bar{u}_{i .}\right)
\end{aligned}
$$

or, in simplified notation:

$$
\ddot{y}_{i, t}=\beta_{0}+\beta_{1} \ddot{y}_{i, t-1}+\beta_{2} \ddot{X}_{i, t}+\beta_{3} \ddot{W}_{i, t}+\ddot{\gamma}_{t}+\ddot{u}_{i, t}
$$

Since the mean of all time-invariant company-specific effects is itself $\delta_{i}$, these company fixed effects - and hence one potential source of endogeneity - are removed from the equation. However, the fixed effects estimator does not eliminate the dynamic panel bias because the transformed lagged dependent variable is still correlated with $\ddot{u}_{i, t}$ by construction. This relation becomes apparent when the transformed lagged dependent variable and the transformed error term are displayed as follows:

$$
\begin{gathered}
\ddot{y}_{i, t-1}=y_{i, t-1}-\frac{1}{T-1}\left(y_{i 1}+\ldots y_{i t}+\ldots+y_{i, T-1}\right) \\
\ddot{u}_{i, t}=u_{i t}-\frac{1}{T-1}\left(u_{i 2}+\ldots u_{i, t-1}+\ldots u_{i T}\right)
\end{gathered}
$$

As these equations show, $y_{i, t-1}$ in the first equation is correlated with $u_{i, t-1}$ in the second equation. In the same manner, $u_{i t}$ in the second equation is correlated with $y_{i t}$ in the first one. ${ }^{29}$ Therefore, the assumption of strict exogeneity of the regressors is violated, and also the within groups estimator is biased in the presence of a lagged dependent variable. ${ }^{30}$ The bias remains if the number of individuals (in this case, companies) in the sample increases. However, as with ordinary least squares estimation, the bias decreases as $\mathrm{T}$ increases.

\subsubsection{The difference GMM estimator}

In the case of difference GMM, in a first step, Equation E.40 is transformed by first-differencing, leading, in generalized form, to

$$
\Delta y_{i, t}=\beta_{0}+\beta_{1} \cdot \Delta y_{i, t-1}+\beta_{2} \cdot \Delta X_{i, t}+\beta_{3} \cdot \Delta W_{i, t}+\Delta \gamma_{t}+\Delta u_{i, t}
$$

\footnotetext{
${ }^{29}$ There are many other correlated pairs, but because all the items in these other pairs contain $\frac{1}{T-1}$, the correlation is second order (Roodman, 2009).

${ }^{30}$ Random effects models are not considered here because the company-specific fixed effects are assumed to be correlated with some of the explanatory variables. As one crucial assumption of random effects models is a zero mean of the company-specific effects conditional on the explanatory variables, the results from a random effects model would be biased and inconsistent. However, note that the random effects estimator is also biased in the presence of a lagged dependent variable (in the context of random effects models generalized least squares (GLS) is applied and after quasi-demeaning $y_{i, t}-\theta \overline{y_{i}}$. is correlated with $\epsilon_{i, t}-\theta \overline{\epsilon_{i}}$.).
} 
As Equation E.45 shows, company fixed effects are eliminated by the transformation because they are time invariant, but the lagged dependent variable is correlated with the error term through $y_{i, t-1}$ and $u_{i, t-1}$. However, it is now possible to use longer lags of the lagged dependent variable as instruments since they are orthogonal to the error and correlated with the (differenced) lagged dependent variable. Under difference GMM, it is possible to use all available lags as instruments for the differenced lagged dependent variable. That is, $y_{i, 1}$ is available as an instrument in $\mathrm{t}=3$, $y_{i, 1}$ and $y_{i, 2}$ are available as instruments in $\mathrm{t}=4$ and so forth. ${ }^{31}$ All instruments are therefore drawn from within the dataset, and the transformed lagged dependent variable is instrumented with lagged levels. The use of lagged levels as instruments for endogenous variables is possible with not only a lagged dependent variable but also other endogenous explanatory variables.

One important drawback of the differencing approach is that it decreases the sample size in panels with gaps because if one observation is missing, two observation periods cannot be used in the analysis. Therefore, Arellano \& Bover, 1995, developed so-called "orthogonal deviations", within which the average of all available future observations, rather than the previous observation, is deducted from the current observation. They also show that in balanced panels, optimal estimators are invariant to the method of transformation that is used to eliminate time-invariant fixed effects (see also Roodman, 2009).

\footnotetext{
${ }^{31}$ The advantage of difference GMM compared with two-stage least squares (2SLS) estimates is that in 2SLS, the sample is reduced when longer lags are used as instruments because observations are dropped if instruments are not available. By contrast, in difference GMM, a set of instruments is built for each time period whereby missing values are substituted with zero (Roodman, 2009).
} 


\subsection{Results of robustness checks}

Table E.14: Pooled cross-section estimates including size effects

\begin{tabular}{|c|c|c|c|}
\hline Variable & Investment rate 1 & Investment rate 2 & Investment rate 3 \\
\hline \multirow[t]{2}{*}{ Tax rate } & $-1.158^{* *}$ & $-1.325^{* * *}$ & $-1.376^{* * *}$ \\
\hline & $(-2.50)$ & $(-3.31)$ & $(-3.14)$ \\
\hline \multirow[t]{2}{*}{ Pvda machinery } & $0.079^{* * *}$ & $0.045^{* * *}$ & $0.071 * * *$ \\
\hline & $(7.33)$ & $(4.73)$ & $(6.77)$ \\
\hline \multirow[t]{2}{*}{ Pvda machinery*Size2 } & $-0.041^{* * *}$ & -0.011 & $-0.031 * * *$ \\
\hline & $(-3.88)$ & $(-1.09)$ & $(-2.92)$ \\
\hline \multirow[t]{2}{*}{ Pvda machinery*Size3 } & $-0.062^{* * *}$ & $-0.028 * * *$ & $-0.053^{* * *}$ \\
\hline & $(-5.82)$ & $(-2.96)$ & $(-5.06)$ \\
\hline \multirow[t]{2}{*}{ Pvda machinery*Size4 } & $-0.075^{* * *}$ & $-0.039 * * *$ & $-0.067 * * *$ \\
\hline & $(-6.91)$ & $(-4.07)$ & $(-6.31)$ \\
\hline \multirow[t]{2}{*}{ Pvda buildings } & -0.003 & -0.003 & -0.003 \\
\hline & $(-0.65)$ & $(-0.84)$ & $(-0.84)$ \\
\hline \multirow[t]{2}{*}{ Pvda buildings*Size2 } & $-0.021^{* * *}$ & $-0.011^{* * *}$ & $-0.017^{* * *}$ \\
\hline & $(-5.34)$ & $(-3.12)$ & $(-4.35)$ \\
\hline \multirow[t]{2}{*}{ Pvda buildings $*$ Size3 } & $-0.018^{* * *}$ & $-0.009 * *$ & $-0.149^{* * *}$ \\
\hline & $(-4.10)$ & $(-2.44)$ & $(-3.57)$ \\
\hline \multirow[t]{2}{*}{ Pvda buildings*Size4 } & $-0.022^{* * *}$ & $-0.013^{* * *}$ & $-0.020 * * *$ \\
\hline & $(-4.91)$ & $(-3.34)$ & $(-4.51)$ \\
\hline \multirow[t]{2}{*}{ Pvda patents } & $0.022^{* * *}$ & & \\
\hline & $(3.72)$ & & \\
\hline \multirow[t]{2}{*}{ Pvda patents*Size2 } & $-0.011^{* *}$ & & \\
\hline & $(-2.54)$ & & \\
\hline \multirow[t]{2}{*}{ Pvda patents*Size3 } & $-0.016^{* * *}$ & & \\
\hline & $(-3.30)$ & & \\
\hline \multirow[t]{2}{*}{ Pvda patents $*$ Size 4} & $-0.019 * * *$ & & \\
\hline & $(-3.66)$ & & \\
\hline \multirow[t]{2}{*}{ Size2 } & $6.001^{* * *}$ & $1.951^{* *}$ & $4.000^{* * *}$ \\
\hline & $(5.84)$ & $(2.20)$ & $(4.12)$ \\
\hline \multirow[t]{2}{*}{ Size3 } & $8.132^{* * *}$ & $3.472^{* * *}$ & $5.874^{* * *}$ \\
\hline & $(7.84)$ & $(3.91)$ & $(6.04)$ \\
\hline \multirow[t]{2}{*}{ Size4 } & $9.569 * * *$ & $4.602^{* * *}$ & $7.274^{* * *}$ \\
\hline & $(8.59)$ & $(5.16)$ & $(7.39)$ \\
\hline Industry-year fixed effects & Yes & Yes & Yes \\
\hline Number of observations & 107,033 & 107,033 & 107,033 \\
\hline $\mathrm{R}^{2}$ & 0.045 & 0.038 & 0.045 \\
\hline Prob $>$ F & 0.000 & 0.000 & 0.000 \\
\hline \multicolumn{4}{|c|}{$\begin{array}{l}\text { The table shows the linear regression results for firm investment behavior, estimated over the period from } \\
1998 \text { to } 2007 \text {. The sample includes only companies that do not have tax loss carry-forwards. The dependent } \\
\text { variables are different (gross) investment rates, as defined in Section E.4.2. Additional explanatory variables } \\
\text { are included in all regressions (see Table E. } 11 \text { for descriptions). Size is an indicator variable for company size, } \\
\text { measured by average total assets. The variable is one if a company belongs to the smallest (size1) or largest } \\
\text { (size4) } 25 \text { percent of all corporations in the sample. Industry, year and industry-year indicator variables are } \\
\text { included in all three specifications but are not reported. Standard errors allow for heteroskedasticity and are } \\
\text { clustered by firm; t-values are shown in parentheses. * } *^{* *} \text { and } * * * \text { indicate statistical significance at the ten- } \\
\text { five- and one-percent level, respectively. Prob }>\mathrm{F} \text { shows the p-value associated with the F-test for the null } \\
\text { hypothesis that all coefficients are equal to zero. }\end{array}$} \\
\hline
\end{tabular}


Table E.15: Panel data estimates including size effects

\begin{tabular}{|c|c|c|c|c|c|c|}
\hline \multirow{2}{*}{$\frac{\text { Variable }}{\text { Tax rate }}$} & \multicolumn{2}{|c|}{ Investment rate 1} & \multicolumn{2}{|c|}{ Investment rate 2} & \multicolumn{2}{|c|}{ Investment rate 3} \\
\hline & $\begin{array}{c}0.271 \\
(0.72)\end{array}$ & $\begin{array}{l}-0.327 \\
(-0.69)\end{array}$ & $\begin{array}{c}0.173 \\
(0.52)\end{array}$ & $\begin{array}{c}-0.270 \\
(-0.66)\end{array}$ & $\begin{array}{c}0.097 \\
(0.27)\end{array}$ & $\begin{array}{l}-0.456 \\
(-1.02)\end{array}$ \\
\hline Pvda machinery & $\begin{array}{l}0.043^{* * *} \\
(4.53)\end{array}$ & $\begin{array}{l}0.124^{* * *} \\
(3.82)\end{array}$ & $\begin{array}{l}0.015^{*} \\
(1.78)\end{array}$ & $\begin{array}{l}0.102^{* * *} \\
(3.44)\end{array}$ & $\begin{array}{l}0.039^{* * *} \\
(4.23)\end{array}$ & $\begin{array}{l}0.141^{* * *} \\
(4.24)\end{array}$ \\
\hline Pvda machinery*Size2 & $\begin{array}{l}-0.014^{*} \\
(-1.74)\end{array}$ & $\begin{array}{l}-0.099^{* * *} \\
(-2.67)\end{array}$ & $\begin{array}{c}0.005 \\
(0.75)\end{array}$ & $\begin{array}{l}-0.086^{* *} \\
(-2.55)\end{array}$ & $\begin{array}{l}-0.010 \\
(-1.19)\end{array}$ & $\begin{array}{l}-0.122^{* * *} \\
(-3.27)\end{array}$ \\
\hline Pvda machinery*Size3 & $\begin{array}{l}-0.037^{* * *} \\
(-4.57)\end{array}$ & $\begin{array}{l}-0.118^{* * *} \\
(-3.53)\end{array}$ & $\begin{array}{l}-0.014^{*} \\
(-1.92)\end{array}$ & $\begin{array}{l}-0.099^{* * *} \\
(-3.23)\end{array}$ & $\begin{array}{l}-0.034^{* * *} \\
(-4.35)\end{array}$ & $\begin{array}{l}-0.135^{* * *} \\
(-3.93)\end{array}$ \\
\hline Pvda machinery*Size4 & $\begin{array}{l}-0.050^{* * *} \\
(-5.26)\end{array}$ & $\begin{array}{l}-0.128^{* * *} \\
(-3.89)\end{array}$ & $\begin{array}{l}-0.021^{* * *} \\
(-2.62)\end{array}$ & $\begin{array}{l}-0.106^{* * *} \\
(-3.51)\end{array}$ & $\begin{array}{l}-0.047^{* * *} \\
(-5.21)\end{array}$ & $\begin{array}{l}-0.143^{*} \\
(-4.24)\end{array}$ \\
\hline Pvda buildings & $\begin{array}{l}0.008^{*} \\
(1.76)\end{array}$ & $\begin{array}{l}-0.015^{*} \\
(-1.91)\end{array}$ & $\begin{array}{c}0.006 \\
(1.39)\end{array}$ & $\begin{array}{l}-0.017^{* *} \\
(-2.52)\end{array}$ & $\begin{array}{l}0.008^{*} \\
(1.88)\end{array}$ & $\begin{array}{l}-0.016^{* *} \\
(-2.19)\end{array}$ \\
\hline Pvda buildings $*$ Size2 & $\begin{array}{l}-0.009^{* * *} \\
(-2.84)\end{array}$ & $\begin{array}{c}0.004 \\
(1.29)\end{array}$ & $\begin{array}{l}-0.006^{* *} \\
(-1.96)\end{array}$ & $\begin{array}{r}0.011 \\
(0.81)\end{array}$ & $\begin{array}{l}-0.009^{* * *} \\
(-2.84)\end{array}$ & $\begin{array}{r}0.007 \\
(0.54)\end{array}$ \\
\hline Pvda buildings $*$ Size3 & $\begin{array}{l}-0.007^{*} \\
(-1.76)\end{array}$ & $\begin{array}{c}0.015 \\
(1.30)\end{array}$ & $\begin{array}{l}-0.006^{*} \\
(-1.90)\end{array}$ & $\begin{array}{l}0.018^{*} \\
(1.71)\end{array}$ & $\begin{array}{l}-0.008^{* *} \\
(-2.15)\end{array}$ & $\begin{array}{c}0.016 \\
(1.42)\end{array}$ \\
\hline Pvda buildings $*$ Size4 & $\begin{array}{l}-0.008^{* *} \\
(-2.06)\end{array}$ & $\begin{array}{l}0.027^{* * *} \\
(2.61)\end{array}$ & $\begin{array}{l}-0.009^{* *} \\
(-2.55)\end{array}$ & $\begin{array}{l}0.024^{* *} \\
(2.53)\end{array}$ & $\begin{array}{l}-0.010^{* * *} \\
(-2.65)\end{array}$ & $\begin{array}{l}0.024^{* *} \\
(2.29)\end{array}$ \\
\hline Pvda patents & $\begin{array}{l}0.017^{* * *} \\
(2.58)\end{array}$ & $\begin{array}{c}-0.002 \\
(-0.09)\end{array}$ & & & & \\
\hline Pvda patents $*$ Size2 & $\begin{array}{c}0.000 \\
(0.11)\end{array}$ & $\begin{array}{c}0.020 \\
(0.82)\end{array}$ & & & & \\
\hline Pvda patents*Size3 & $\begin{array}{l}-0.007^{*} \\
(-1.95)\end{array}$ & $\begin{array}{c}-0.002 \\
(-0.07)\end{array}$ & & & & \\
\hline Pvda patents $*$ Size 4 & $\begin{array}{l}-0.012^{* * *} \\
(-2.89)\end{array}$ & $\begin{array}{c}-0.006 \\
(-0.24)\end{array}$ & & & & \\
\hline Size2 & $\begin{array}{l}1.822^{* *} \\
(2.28)\end{array}$ & & $\begin{array}{l}-0.006 \\
(-0.01)\end{array}$ & & $\begin{array}{l}1.448^{*} \\
(1.92)\end{array}$ & \\
\hline Size3 & $\begin{array}{l}4.185^{* * *} \\
(5.17)\end{array}$ & & $\begin{array}{l}1.687^{* *} \\
(2.51)\end{array}$ & & $\begin{array}{l}3.493^{* * *} \\
(4.66)\end{array}$ & \\
\hline Size4 & $\begin{array}{l}5.772^{* * *} \\
(5.95)\end{array}$ & & $\begin{array}{l}2.454^{* * *} \\
(3.23)\end{array}$ & & $\begin{array}{l}4.665^{* * *} \\
(5.47)\end{array}$ & \\
\hline Country fixed effects & Yes & No & Yes & No & Yes & No \\
\hline Firm fixed effects & No & Yes & No & Yes & No & Yes \\
\hline Number of observ. & 131,967 & 131,967 & 131,967 & 131,967 & 131,967 & 131,967 \\
\hline (Within) $\mathrm{R}^{2}$ & 0.034 & 0.021 & 0.025 & 0.019 & 0.035 & 0.022 \\
\hline Prob $>F$ & 0.000 & 0.000 & 0.000 & 0.000 & 0.000 & 0.000 \\
\hline
\end{tabular}

The table shows the linear regression results for firm investment behavior, estimated over the period from 1998 to 2007. The sample includes only companies that do not have tax loss carry-forwards. The dependent variables are different (gross) investment rates, as defined in Section E.4.2. Additional explanatory variables are included in all regressions (see Table E.11 for descriptions). Size is an indicator variable for company size, measured by average total assets. The variable is one if a company belongs to the smallest (size1) or largest (size4) 25 percent of all corporations in the sample. Industry, year and industry-year indicator variables are included in all three specifications but are not reported. In addition, either country or firm fixed effects are included but not reported. Standard errors allow for heteroskedasticity and are clustered by firm; t-values are shown in parentheses. $*, * *$ and $* * *$ indicate statistical significance at the ten-, five- and one-percent level, respectively. Prob $>$ F shows the p-value associated with the F-test for the null hypothesis that all coefficients are equal to zero. 
Table E.16: Pooled cross-section estimates - original sample

\begin{tabular}{|c|c|c|c|}
\hline Variable & Investment rate 1 & Investment rate 2 & Investment rate 3 \\
\hline \multirow[t]{2}{*}{ Tax rate } & 0.231 & -0.147 & $-0.388^{*}$ \\
\hline & $(0.89)$ & $(-0.68)$ & $(-1.65)$ \\
\hline \multirow[t]{2}{*}{ Pvda machinery } & $0.191^{* * *}$ & $0.119^{* * *}$ & $0.152^{* * *}$ \\
\hline & $(19.00)$ & $(16.16)$ & $(18.09)$ \\
\hline \multirow[t]{2}{*}{ Pvda mach. $* \ln (\text { total assets })_{t-1}$} & $-0.020 * * *$ & $-0.011^{* * *}$ & $-0.015 * * *$ \\
\hline & $(-17.27)$ & $(-13.71)$ & $(-15.95)$ \\
\hline \multirow[t]{2}{*}{ Pvda buildings } & $0.030 * * *$ & $0.019^{* * *}$ & $0.025^{* * *}$ \\
\hline & $(13.89)$ & $(10.00)$ & $(12.09)$ \\
\hline \multirow{2}{*}{ Pvda buil. $* \ln (\text { total assets })_{t-1}$} & $-0.007 * * *$ & $-0.004^{* * *}$ & $-0.006^{* * *}$ \\
\hline & $(-35.62)$ & $(-26.72)$ & $(-33.43)$ \\
\hline \multirow[t]{2}{*}{ Pvda patents } & $0.015^{* * *}$ & & \\
\hline & $(3.90)$ & & \\
\hline \multirow{2}{*}{ Pvda pat. $* \ln (\text { total assets })_{t-1}$} & 0.000 & & \\
\hline & $(0.24)$ & & \\
\hline \multirow[t]{2}{*}{$\operatorname{Ln}(\text { total assets })_{t-1}$} & $2.127^{* * *}$ & $1.257^{* * *}$ & $1.667^{* * *}$ \\
\hline & $(23.10)$ & $(17.00)$ & $(19.55)$ \\
\hline \multirow{2}{*}{ Scaled cash flow } & $1.206^{* * *}$ & $0.970^{* * *}$ & $1.114^{* * *}$ \\
\hline & $(31.67)$ & $(30.06)$ & $(30.01)$ \\
\hline \multirow{2}{*}{ Scaled cash flow $t-1$} & $0.042^{* * *}$ & $0.032^{* * *}$ & $0.040 * * *$ \\
\hline & $(3.22)$ & $(3.18)$ & $(3.21)$ \\
\hline \multirow[t]{2}{*}{ Leverage $_{t-1}$} & $0.020^{*}$ & $-0.061^{* * *}$ & $-0.039 * * *$ \\
\hline & $(1.94)$ & $(-7.15)$ & $(-4.00)$ \\
\hline \multirow[t]{2}{*}{ Average tangibility } & $-0.999 * * *$ & $-0.215^{* * *}$ & $-0.804^{* * *}$ \\
\hline & $(-140.36)$ & $(-31.82)$ & $(-106.10)$ \\
\hline \multirow[t]{2}{*}{ Year of incorporation } & $0.124^{* * *}$ & $0.125^{* * *}$ & $0.144^{* * *}$ \\
\hline & $(15.50)$ & $(18.36)$ & $(18.83)$ \\
\hline \multirow[t]{2}{*}{ Profit prior year } & $-0.044^{* * *}$ & $-0.014^{* *}$ & $-0.019 * * *$ \\
\hline & $(-6.35)$ & $(-2.38)$ & $(-2.83)$ \\
\hline \multirow[t]{2}{*}{ Country risk } & 0.009 & $0.064^{* * *}$ & $0.060^{* * *}$ \\
\hline & $(0.63)$ & $(6.63)$ & $(5.76)$ \\
\hline \multirow[t]{2}{*}{ Unemployment rate } & $-2.187^{* * *}$ & $-1.449 * * *$ & $-1.219 * * *$ \\
\hline & $(-5.87)$ & $(-4.74)$ & $(-3.65)$ \\
\hline \multirow[t]{2}{*}{ Hourly wages } & $-0.006^{* *}$ & $-0.009^{* * *}$ & $-0.011 * * *$ \\
\hline & $(-2.42)$ & $(-4.24)$ & $(-4.82)$ \\
\hline \multirow[t]{2}{*}{ Inflation } & $0.970 * * *$ & $0.611^{* * *}$ & $0.746^{* * *}$ \\
\hline & $(6.54)$ & $(5.05)$ & $(5.65)$ \\
\hline \multirow[t]{2}{*}{ Treasury rate } & -0.936 & 1.086 & -1.291 \\
\hline & $(-0.68)$ & $(0.91)$ & $(-1.00)$ \\
\hline \multirow[t]{2}{*}{ Market size } & $-0.382^{* * *}$ & $-0.261^{* * *}$ & $-0.341 * * *$ \\
\hline & $(-10.94)$ & $(-8.47)$ & $(-10.04)$ \\
\hline \multirow[t]{2}{*}{ GDP growth } & $2.396^{* * *}$ & $2.395^{* * *}$ & $2.792^{* * *}$ \\
\hline & $(5.39)$ & $(6.39)$ & $(6.79)$ \\
\hline Ln(GDP per capita) & 0.007 & 0.012 & $0.050 * * *$ \\
\hline & $(0.45)$ & $(0.94)$ & $(3.52)$ \\
\hline EU 10 & $0.615^{* * *}$ & $0.592^{* * *}$ & $0.784^{* * *}$ \\
\hline & $(5.63)$ & $(6.12)$ & $(7.37)$ \\
\hline Eurozone & -0.027 & $0.124^{* * *}$ & $0.150^{* * *}$ \\
\hline & $(-0.74)$ & $(4.60)$ & $(5.07)$ \\
\hline Constant & $-12.559^{* * *}$ & $-7.380^{* * *}$ & $-8.821 * * *$ \\
\hline & $(-12.60)$ & $(-8.79)$ & $(-9.35)$ \\
\hline $\mathrm{R}^{2}$ & 0.044 & 0.037 & 0.043 \\
\hline
\end{tabular}

The table shows the linear regression results for firm investment behavior, estimated over the period from 1998 to 2007. The sample includes only companies that do not have tax loss carry-forwards (number of observations $=2,556,240$ ). The dependent variables are different (gross) investment rates, as defined in Section E.4.2. See Table E.11 for a description of the dependent and independent variables. Industry, year and industryyear indicator variables are included in all three specifications but are not reported. Standard errors allow for heteroskedasticity and are clustered by firm; t-values are shown in parentheses. ${ }^{*},{ }^{* *}$ and ${ }^{* * *}$ indicate statistical significance at the ten-, five- and one-percent level, respectively. The p-value associated with the F-test for the null hypothesis that all coefficients are equal to zero is zero in all three specifications. 
Table E.17: Panel data estimates with country fixed effects - original sample

\begin{tabular}{|c|c|c|c|}
\hline Variable & Investment rate 1 & Investment rate 2 & Investment rate 3 \\
\hline \multirow[t]{2}{*}{ Tax rate } & 0.001 & -0.324 & $-0.419^{*}$ \\
\hline & $(0.00)$ & $(-1.42)$ & $(-1.68)$ \\
\hline \multirow[t]{2}{*}{ Pvda machinery } & $0.156^{* * *}$ & $0.083^{* * *}$ & $0.117^{* * *}$ \\
\hline & $(13.85)$ & $(10.30)$ & $(12.82)$ \\
\hline \multirow[t]{2}{*}{ Pvda mach. $* \ln (\text { total assets })_{t-1}$} & $-0.018^{* * *}$ & $-0.009^{* * *}$ & $-0.013^{* * *}$ \\
\hline & $(-14.43)$ & $(-10.73)$ & $(-13.31)$ \\
\hline \multirow[t]{2}{*}{ Pvda buildings } & $0.027^{* * *}$ & $0.015^{* * *}$ & $0.024^{* * *}$ \\
\hline & $(10.28)$ & $(6.23)$ & $(9.00)$ \\
\hline \multirow{2}{*}{ Pvda buil. $* \ln (\text { total assets })_{t-1}$} & $-0.007 * * *$ & $-0.005^{* * *}$ & $-0.006^{* * *}$ \\
\hline & $(-34.23)$ & $(-26.47)$ & $(-32.32)$ \\
\hline \multirow[t]{2}{*}{ Pvda patents } & $0.017^{* * *}$ & & \\
\hline & $(3.01)$ & & \\
\hline \multirow{2}{*}{ Pvda pat. $* \ln (\text { total assets })_{t-1}$} & -0.000 & & \\
\hline & $(-0.37)$ & & \\
\hline \multirow[t]{2}{*}{$\operatorname{Ln}(\text { total assets })_{t-1}$} & $1.977^{* * *}$ & $1.090^{* * *}$ & $1.507^{* * *}$ \\
\hline & $(20.56)$ & $(14.25)$ & $(17.06)$ \\
\hline \multirow{2}{*}{ Scaled cash flow } & $1.207^{* * *}$ & $0.972^{* * *}$ & $1.116^{* * *}$ \\
\hline & $(31.61)$ & $(29.98)$ & $(29.92)$ \\
\hline \multirow[t]{2}{*}{ Scaled cash flow $t-1$} & $0.042^{* * *}$ & $0.032^{* * *}$ & $0.040^{* * *}$ \\
\hline & $(3.22)$ & $(3.18)$ & $(3.21)$ \\
\hline \multirow[t]{2}{*}{ Leverage $_{t-1}$} & $0.020 *$ & $-0.061 * * *$ & $-0.038 * * *$ \\
\hline & $(1.94)$ & $(-7.06)$ & $(-3.92)$ \\
\hline \multirow[t]{2}{*}{ Average tangibility } & $-0.998^{* * *}$ & $-0.213^{* * *}$ & $-0.802^{* * *}$ \\
\hline & $(-140.34)$ & $(-31.51)$ & $(-105.92)$ \\
\hline \multirow[t]{2}{*}{ Year of incorporation } & $0.125^{* * *}$ & $0.126^{* * *}$ & $0.145^{* * *}$ \\
\hline & $(15.57)$ & $(18.46)$ & $(18.89)$ \\
\hline \multirow[t]{2}{*}{ Profit prior year } & $-0.043^{* * *}$ & $-0.012^{* *}$ & $-0.018^{* * *}$ \\
\hline & $(-6.22)$ & $(-2.17)$ & $(-2.66)$ \\
\hline \multirow[t]{2}{*}{ Country risk } & -0.032 & -0.012 & -0.041 \\
\hline & $(-1.18)$ & $(-0.51)$ & $(-1.56)$ \\
\hline \multirow{2}{*}{ Unemployment rate } & $-3.017^{* * *}$ & $-2.610^{* * *}$ & $-2.862^{* * *}$ \\
\hline & $(-5.39)$ & $(-5.22)$ & $(-5.27)$ \\
\hline \multirow{2}{*}{ Hourly wages } & -0.003 & -0.005 & -0.003 \\
\hline & $(-0.44)$ & $(-0.93)$ & $(-0.56)$ \\
\hline \multirow{2}{*}{ Inflation } & $0.697^{* * *}$ & $0.464^{* *}$ & $0.768^{* * *}$ \\
\hline & $(2.63)$ & $(2.04)$ & $(3.07)$ \\
\hline \multirow{2}{*}{ Treasury rate } & $-4.363^{* * *}$ & $-3.633^{* *}$ & $-4.265^{* * *}$ \\
\hline & $(-2.57)$ & $(-2.46)$ & $(-2.63)$ \\
\hline \multirow[t]{2}{*}{ Market size } & -1.857 & $-2.872^{* *}$ & $-3.649 * * *$ \\
\hline & $(-1.30)$ & $(-2.44)$ & $(-2.82)$ \\
\hline \multirow[t]{2}{*}{ GDP growth } & $3.054^{* * *}$ & $3.038^{* * *}$ & $3.696^{* * *}$ \\
\hline & $(5.23)$ & $(6.45)$ & $(7.12)$ \\
\hline Ln(GDP per capita) & $-1.096^{* * *}$ & $-1.543^{* * *}$ & $-1.692^{* * *}$ \\
\hline & $(-2.68)$ & $(-4.63)$ & $(-4.58)$ \\
\hline EU 10 & 4.590 & $7.583^{* *}$ & $9.735^{* * *}$ \\
\hline & $(1.16)$ & $(2.35)$ & $(2.75)$ \\
\hline Constant & 23.516 & $50.942^{* *}$ & $61.704^{* * *}$ \\
\hline & $(0.91)$ & $(2.43)$ & $(2.68)$ \\
\hline Number of observations & $2,556,240$ & $2,556,240$ & $2,556,240$ \\
\hline $\mathrm{R}^{2}$ & 0.045 & 0.037 & 0.042 \\
\hline $\begin{array}{l}\text { The table shows the linear regres } \\
1998 \text { to } 2007 \text {. The sample include } \\
\text { variables are different (gross) inve } \\
\text { of the dependent and independent } \\
\text { included in all three specifications } \\
\text { clustered by firm; t-values are shor } \\
\text { five- and one-percent level, respect }\end{array}$ & $\begin{array}{l}\text { on results for firm inve } \\
\text { only companies that do } \\
\text { ment rates, as defined } \\
\text { rariables. Industry, year, } \\
\text { out are not reported. St } \\
\text { n in parentheses. }{ }^{*},{ }^{*} \text { a }\end{array}$ & $\begin{array}{l}\text { ment behavior, estimat } \\
\text { lot have tax loss carry- } \\
\text { Section E.4.2. See Tab } \\
\text { ndustry-year and count } \\
\text { adard errors allow for h } \\
d * * * \text { indicate statistica } \\
\text { ed with the F-test for th }\end{array}$ & $\begin{array}{l}\text { d over the period from } \\
\text { rwards. The dependent } \\
\text { E.11 for a description } \\
\text { indicator variables are } \\
\text { eroskedasticity and are } \\
\text { significance at the ten-, } \\
\text { null hypothesis that all }\end{array}$ \\
\hline
\end{tabular}


Table E.18: Panel data estimates with firm fixed effects - original sample

\begin{tabular}{|c|c|c|c|}
\hline Variable & Investment rate 1 & Investment rate 2 & Investment rate 3 \\
\hline \multirow[t]{2}{*}{ Tax rate } & $0.749^{* *}$ & 0.203 & 0.267 \\
\hline & $(2.34)$ & $(0.73)$ & $(0.89)$ \\
\hline \multirow[t]{2}{*}{ Pvda machinery } & $0.078 * * *$ & $0.058^{* * *}$ & $0.055^{* *}$ \\
\hline & $(2.87)$ & $(2.61)$ & $(2.22)$ \\
\hline \multirow{2}{*}{ Pvda mach. $* \ln (\text { total assets })_{t-1}$} & $-0.008^{* *}$ & $-0.006^{* *}$ & -0.005 \\
\hline & $(-2.46)$ & $(-2.26)$ & $(-1.64)$ \\
\hline \multirow[t]{2}{*}{ Pvda buildings } & $0.046^{* * *}$ & $0.009^{*}$ & $0.024^{* * *}$ \\
\hline & $(8.74)$ & $(1.88)$ & $(4.89)$ \\
\hline \multirow{2}{*}{ Pvda buil. $* \ln (\text { total assets })_{t-1}$} & $-0.010^{* * *}$ & $-0.002^{* * *}$ & $-0.006^{* * *}$ \\
\hline & $(-10.02)$ & $(-2.87)$ & $(-6.33)$ \\
\hline \multirow[t]{2}{*}{ Pvda patents } & $0.072^{* * *}$ & & \\
\hline & $(3.72)$ & & \\
\hline \multirow{2}{*}{ Pvda pat. $* \ln (\text { total assets })_{t-1}$} & $-0.009 * * *$ & & \\
\hline & $(-3.65)$ & & \\
\hline \multirow{2}{*}{$\operatorname{Ln}(\text { total assets })_{t-1}$} & $1.310^{* * *}$ & 0.120 & 0.114 \\
\hline & $(3.93)$ & $(0.51)$ & $(0.43)$ \\
\hline \multirow{2}{*}{ Scaled cash flow } & $1.157^{* * *}$ & $0.962^{* * *}$ & $1.081^{* * *}$ \\
\hline & $(23.51)$ & $(23.33)$ & $(23.36)$ \\
\hline \multirow[t]{2}{*}{ Scaled cash flow $t-1$} & $0.067^{* * *}$ & $0.058^{* * *}$ & $0.065^{* * *}$ \\
\hline & $(3.47)$ & $(3.48)$ & $(3.47)$ \\
\hline \multirow[t]{2}{*}{ Leverage $_{t-1}$} & $-1.068^{* * *}$ & $-1.063^{* * *}$ & $-1.164^{* * *}$ \\
\hline & $(-38.14)$ & $(-46.54)$ & $(-46.56)$ \\
\hline \multirow[t]{2}{*}{ Year of incorporation } & $-0.032^{* * *}$ & $0.048^{* * *}$ & $0.036^{* * *}$ \\
\hline & $(-3.08)$ & $(5.45)$ & $(3.66)$ \\
\hline \multirow[t]{2}{*}{ Profit prior year } & $0.104^{* * *}$ & $0.118^{* * *}$ & $0.130^{* * *}$ \\
\hline & $(13.08)$ & $(17.52)$ & $(17.44)$ \\
\hline \multirow[t]{2}{*}{ Country risk } & -0.045 & 0.023 & 0.001 \\
\hline & $(-1.43)$ & $(0.85)$ & $(0.03)$ \\
\hline \multirow[t]{2}{*}{ Unemployment rate } & $-2.298 * * *$ & $-1.856^{* * *}$ & $-2.496^{* * *}$ \\
\hline & $(-3.37)$ & $(-3.07)$ & $(-3.82)$ \\
\hline \multirow[t]{2}{*}{ Hourly wages } & -0.011 & -0.009 & -0.010 \\
\hline & $(-1.52)$ & $(-1.51)$ & $(-1.58)$ \\
\hline \multirow[t]{2}{*}{ Inflation } & 0.142 & -0.400 & -0.184 \\
\hline & $(0.48)$ & $(-1.51)$ & $(-0.64)$ \\
\hline \multirow[t]{2}{*}{ Treasury rate } & $-11.889^{* * *}$ & $-11.119^{* * *}$ & $-12.526^{* * *}$ \\
\hline & $(-6.18)$ & $(-6.56)$ & $(-6.77)$ \\
\hline \multirow[t]{2}{*}{ Market size } & 0.610 & 1.258 & 0.951 \\
\hline & $(0.37)$ & $(0.90)$ & $(0.63)$ \\
\hline \multirow[t]{2}{*}{ GDP growth } & 0.952 & -0.539 & -0.116 \\
\hline & $(1.43)$ & $(-0.96)$ & $(-0.19)$ \\
\hline \multirow[t]{2}{*}{ Ln(GDP per capita) } & 0.081 & 0.175 & 0.153 \\
\hline & $(0.17)$ & $(0.42)$ & $(0.34)$ \\
\hline \multirow[t]{2}{*}{ Constant } & -21.262 & -24.892 & -18.851 \\
\hline & $(-0.64)$ & $(-0.89)$ & $(-0.62)$ \\
\hline Industry-year fixed effects & Yes & Yes & Yes \\
\hline Firm fixed effects & Yes & Yes & Yes \\
\hline Number of observations & $2,556,240$ & $2,556,240$ & $2,556,240$ \\
\hline Within $\mathrm{R}^{2}$ & 0.040 & 0.036 & 0.038 \\
\hline Prob $>$ F & 0.000 & 0.000 & 0.000 \\
\hline
\end{tabular}

The table shows the linear regression results for firm investment behavior, estimated over the period from 1998 to 2007. The sample includes only companies that do not have tax loss carry-forwards. The dependent variables are different (gross) investment rates, as defined in Section E.4.2. See Table E.11 for a description of the dependent and independent variables. Year, industry-year and firm indicator variables are included in all three specifications but are not reported. Standard errors allow for heteroskedasticity and are clustered by firm; t-values are shown in parentheses. ${ }^{*}, * *$ and ${ }^{* * *}$ indicate statistical significance at the ten-, five- and one-percent level, respectively. Prob $>\mathrm{F}$ is the p-value associated with the F-test for the null hypothesis that all coefficients are equal to zero. 
Table E.19: Pooled cross-section estimates - alternative discount rate

\begin{tabular}{|c|c|c|c|}
\hline Variable & Investment rate 1 & Investment rate 2 & Investment rate 3 \\
\hline \multirow[t]{2}{*}{ Tax rate } & -0.412 & $-0.722^{* *}$ & -0.556 \\
\hline & $(-1.02)$ & $(-2.04)$ & $(-1.44)$ \\
\hline \multirow[t]{2}{*}{ Pvda machinery } & 0.019 & $0.049^{* * *}$ & $0.061^{* * *}$ \\
\hline & $(0.93)$ & $(2.89)$ & $(3.23)$ \\
\hline \multirow{2}{*}{ Pvda mach. $* \ln (\text { total assets })_{t-1}$} & -0.002 & $-0.004^{* *}$ & $-0.007 * * *$ \\
\hline & $(-0.99)$ & $(-2.16)$ & $(-3.21)$ \\
\hline \multirow[t]{2}{*}{ Pvda buildings } & $-0.030 * * *$ & -0.008 & $-0.010^{*}$ \\
\hline & $(-5.19)$ & $(-1.59)$ & $(-1.90)$ \\
\hline \multirow{2}{*}{ Pvda buil. $* \ln (\text { total assets })_{t-1}$} & -0.001 & $-0.002^{* * *}$ & $-0.002^{* * *}$ \\
\hline & $(-1.28)$ & $(-3.55)$ & $(-4.44)$ \\
\hline \multirow[t]{2}{*}{ Pvda patents } & $0.119 * * *$ & & \\
\hline & $(8.30)$ & & \\
\hline \multirow{2}{*}{ Pvda pat. $* \ln (\text { total assets })_{t-1}$} & $-0.012^{* * *}$ & & \\
\hline & $(-7.56)$ & & \\
\hline \multirow[t]{2}{*}{$\operatorname{Ln}(\text { total assets })_{t-1}$} & $1.334^{* * *}$ & $0.503^{* * *}$ & $0.760^{* * *}$ \\
\hline & $(6.84)$ & $(3.30)$ & $(4.49)$ \\
\hline \multirow[t]{2}{*}{ Scaled cash flow } & $1.150 * * *$ & $0.952^{* * *}$ & $1.088^{* * *}$ \\
\hline & $(11.08)$ & $(11.05)$ & $(11.51)$ \\
\hline \multirow{2}{*}{ Scaled cash flow $t-1$} & 0.032 & 0.030 & 0.033 \\
\hline & $(1.26)$ & $(1.24)$ & $(1.30)$ \\
\hline \multirow[t]{2}{*}{ Leverage $_{t-1}$} & $0.148^{* * *}$ & $0.152^{* * *}$ & $0.157^{* * *}$ \\
\hline & $(3.52)$ & $(4.14)$ & $(3.89)$ \\
\hline \multirow[t]{2}{*}{ Average tangibility } & $-0.952^{* * *}$ & $-0.417^{* * *}$ & $-0.927 * * *$ \\
\hline & $(-26.54)$ & $(-12.96)$ & $(-26.03)$ \\
\hline \multirow[t]{2}{*}{ Year of incorporation } & $0.247^{* * *}$ & $0.243^{* * *}$ & $0.273^{* * *}$ \\
\hline & $(4.96)$ & $(5.32)$ & $(5.50)$ \\
\hline \multirow[t]{2}{*}{ Profit prior year } & -0.031 & -0.016 & -0.014 \\
\hline & $(-1.09)$ & $(-0.65)$ & $(-0.52)$ \\
\hline \multirow[t]{2}{*}{ Country risk } & -0.005 & $0.049^{* * *}$ & $0.044^{* *}$ \\
\hline & $(-0.25)$ & $(3.11)$ & $(2.53)$ \\
\hline \multirow{2}{*}{ Unemployment rate } & -0.813 & -0.486 & -0.033 \\
\hline & $(-1.49)$ & $(-1.05)$ & $(-0.07)$ \\
\hline \multirow[t]{2}{*}{ Hourly wages } & $-0.032^{* * *}$ & $-0.024^{* * *}$ & $-0.036 * * *$ \\
\hline & $(-7.17)$ & $(-7.16)$ & $(-9.43)$ \\
\hline \multirow[t]{2}{*}{ Inflation } & $0.795 * *$ & 0.525 & $0.765^{* *}$ \\
\hline & $(2.01)$ & $(1.48)$ & $(1.98)$ \\
\hline \multirow[t]{2}{*}{ Treasury rate } & $-12.222^{* * *}$ & $-9.433^{* * *}$ & $-15.711^{* * *}$ \\
\hline & $(-3.99)$ & $(-3.95)$ & $(-5.92)$ \\
\hline \multirow[t]{2}{*}{ Market size } & $-0.559 * * *$ & $-0.296^{* * *}$ & $-0.426^{* * *}$ \\
\hline & $(-8.32)$ & $(-5.70)$ & $(-7.35)$ \\
\hline \multirow[t]{2}{*}{ GDP growth } & 1.290 & $1.608^{*}$ & $2.350 * *$ \\
\hline & $(1.23)$ & $(1.91)$ & $(2.55)$ \\
\hline Ln(GDP per capita) & $0.101^{* * *}$ & $0.053^{* *}$ & $0.101^{* * *}$ \\
\hline & $(3.85)$ & $(2.27)$ & $(3.93)$ \\
\hline EU 10 & $1.464^{* * *}$ & $0.935^{* * *}$ & $1.360^{* * *}$ \\
\hline & $(8.09)$ & $(5.91)$ & $(7.73)$ \\
\hline Eurozone & $0.257^{* * *}$ & $0.240^{* * *}$ & $0.373^{* * *}$ \\
\hline & $(3.51)$ & $(4.84)$ & $(6.83)$ \\
\hline Constant & -0.838 & 1.059 & 2.558 \\
\hline & $(-0.46)$ & $(0.69)$ & $(1.48)$ \\
\hline $\mathrm{R}^{2}$ & 0.043 & 0.035 & 0.043 \\
\hline
\end{tabular}

The table shows the linear regression results for firm investment behavior, estimated over the period from 1998 to 2007. The sample includes only companies that do not have tax loss carry-forwards (number of observations $=107,033$ ). The dependent variables are different (gross) investment rates, as defined in Section E.4.2. See Table E.11 for a description of the dependent and independent variables. Industry, year and industry-year indicator variables are included in all three specifications but are not reported. Standard errors allow for heteroskedasticity and are clustered by firm; t-values are shown in parentheses. ${ }^{*},{ }^{* *}$ and ${ }^{* * *}$ indicate statistical significance at the ten-, five- and one-percent level, respectively. The p-value associated with the F-test for the null hypothesis that all coefficients are equal to zero is zero in all three specifications. 
Table E.20: Panel data estimates with country fixed effects - alternative discount rate

\begin{tabular}{|c|c|c|c|}
\hline Variable & Investment rate 1 & Investment rate 2 & Investment rate 3 \\
\hline \multirow[t]{2}{*}{ Tax rate } & $-1.063^{* * *}$ & -0.362 & $-0.734^{*}$ \\
\hline & $(-2.63)$ & $(-1.03)$ & $(-1.92)$ \\
\hline \multirow[t]{2}{*}{ Pvda machinery } & $0.090 * * *$ & $0.064^{* * *}$ & $0.097^{* * *}$ \\
\hline & $(4.10)$ & $(3.62)$ & $(4.89)$ \\
\hline \multirow[t]{2}{*}{ Pvda mach. $* \ln (\text { total assets })_{t-1}$} & $-0.011^{* * *}$ & $-0.008^{* * *}$ & $-0.012^{* * *}$ \\
\hline & $(-4.57)$ & $(-4.28)$ & $(-5.58)$ \\
\hline \multirow[t]{2}{*}{ Pvda buildings } & -0.004 & -0.001 & 0.002 \\
\hline & $(-0.73)$ & $(-0.11)$ & $(0.33)$ \\
\hline \multirow{2}{*}{ Pvda buil. $* \ln (\text { total assets })_{t-1}$} & $0.001^{* *}$ & 0.000 & 0.000 \\
\hline & $(2.30)$ & $(1.00)$ & $(0.58)$ \\
\hline \multirow[t]{2}{*}{ Pvda patents } & $0.049 * * *$ & & \\
\hline & $(3.74)$ & & \\
\hline \multirow[t]{2}{*}{ Pvda pat. $* \ln (\text { total assets })_{t-1}$} & $-0.005^{* * *}$ & & \\
\hline & $(-3.36)$ & & \\
\hline \multirow[t]{2}{*}{$\operatorname{Ln}(\text { total assets })_{t-1}$} & $1.201^{* * *}$ & $0.627^{* * *}$ & $0.937^{* * *}$ \\
\hline & $(6.83)$ & $(4.36)$ & $(5.80)$ \\
\hline \multirow{2}{*}{ Scaled cash flow } & $0.605^{* * *}$ & $0.468^{* * *}$ & $0.595^{* * *}$ \\
\hline & $(3.92)$ & $(4.10)$ & $(4.01)$ \\
\hline \multirow[t]{2}{*}{ Scaled cash flow $t-1$} & $0.131^{*}$ & $0.105^{*}$ & $0.130^{*}$ \\
\hline & $(1.87)$ & $(1.80)$ & $(1.86)$ \\
\hline \multirow[t]{2}{*}{ Leverage $_{t-1}$} & $0.100 * * *$ & $0.092^{* * *}$ & $0.104^{* * *}$ \\
\hline & $(2.83)$ & $(3.05)$ & $(3.08)$ \\
\hline \multirow[t]{2}{*}{ Average tangibility } & $-0.894^{* * *}$ & $-0.386^{* * *}$ & $-0.850^{* * *}$ \\
\hline & $(-30.36)$ & $(-14.87)$ & $(-29.13)$ \\
\hline \multirow[t]{2}{*}{ Year of incorporation } & $0.373^{* * *}$ & $0.312^{* * *}$ & $0.379^{* * *}$ \\
\hline & $(4.46)$ & $(4.49)$ & $(4.81)$ \\
\hline \multirow{2}{*}{ Profit prior year } & 0.001 & 0.017 & 0.016 \\
\hline & $(0.03)$ & $(0.77)$ & $(0.60)$ \\
\hline \multirow[t]{2}{*}{ Country risk } & 0.008 & 0.000 & -0.001 \\
\hline & $(0.19)$ & $(0.00)$ & $(-0.02)$ \\
\hline \multirow[t]{2}{*}{ Unemployment rate } & -0.023 & 0.729 & 0.455 \\
\hline & $(-0.03)$ & $(1.06)$ & $(0.60)$ \\
\hline \multirow[t]{2}{*}{ Hourly wages } & $-0.028 * * *$ & $-0.015^{*}$ & $-0.019^{* *}$ \\
\hline & $(-2.89)$ & $(-1.92)$ & $(-2.21)$ \\
\hline \multirow[t]{2}{*}{ Inflation } & $1.151^{* *}$ & $1.527^{* * *}$ & $1.513^{* * *}$ \\
\hline & $(2.44)$ & $(3.68)$ & $(3.34)$ \\
\hline \multirow[t]{2}{*}{ Treasury rate } & -0.029 & $-6.699^{* *}$ & $-4.962^{*}$ \\
\hline & $(-0.01)$ & $(-2.46)$ & $(-1.66)$ \\
\hline \multirow[t]{2}{*}{ Market size } & -1.149 & $-3.314^{* *}$ & $-3.501^{* *}$ \\
\hline & $(-0.60)$ & $(-2.13)$ & $(-2.05)$ \\
\hline \multirow[t]{2}{*}{ GDP growth } & $2.391^{* * *}$ & $2.253^{* * *}$ & $2.454^{* * *}$ \\
\hline & $(2.65)$ & $(3.11)$ & $(3.08)$ \\
\hline Ln(GDP per capita) & -0.946 & $-1.192^{* *}$ & $-1.227 * *$ \\
\hline & $(-1.62)$ & $(-2.37)$ & $(-2.20)$ \\
\hline EU 10 & 4.336 & $8.161^{* *}$ & $8.581^{* *}$ \\
\hline & $(0.98)$ & $(2.14)$ & $(2.04)$ \\
\hline Constant & 15.218 & $57.812^{* *}$ & $58.502^{*}$ \\
\hline & $(0.44)$ & $(2.08)$ & $(1.91)$ \\
\hline Number of observations & 131,967 & 131,967 & 131,967 \\
\hline $\mathrm{R}^{2}$ & 0.035 & 0.026 & 0.036 \\
\hline $\begin{array}{l}\text { The table shows the linear regres } \\
1998 \text { to } 2007 \text {. The sample includes } \\
\text { variables are different (gross) inver } \\
\text { of the dependent and independent } \\
\text { included in all three specifications } \\
\text { clustered by firm; t-values are shov } \\
\text { five- and one-percent level, respect }\end{array}$ & $\begin{array}{l}\text { ion results for firm inve } \\
\text { only companies that do } \\
\text { tment rates, as defined } \\
\text { variables. Industry, year, } \\
\text { out are not reported. St } \\
n \text { in parentheses. *, ** a } \\
\text { vely. The p-value associa }\end{array}$ & $\begin{array}{l}\text { tment behavior, estimat } \\
\text { not have tax loss carry-f } \\
\text { Section E.4.2. See Tab } \\
\text { industry-year and countr } \\
\text { ndard errors allow for h } \\
d \text { *** indicate statistica } \\
\text { ed with the F-test for th }\end{array}$ & $\begin{array}{l}\text { d over the period from } \\
\text { rwards. The dependent } \\
\text { E.11 for a description } \\
\text { indicator variables are } \\
\text { eroskedasticity and are } \\
\text { significance at the ten-, } \\
\text { null hypothesis that all }\end{array}$ \\
\hline
\end{tabular}


Table E.21: Panel data estimates with firm fixed effects - alternative discount rate

\begin{tabular}{|c|c|c|c|}
\hline Variable & Investment rate 1 & Investment rate 2 & Investment rate 3 \\
\hline \multirow[t]{2}{*}{ Tax rate } & $-1.278^{* * *}$ & $-0.709^{*}$ & $-0.882^{*}$ \\
\hline & $(-2.59)$ & $(-1.71)$ & $(-1.94)$ \\
\hline \multirow[t]{2}{*}{ Pvda machinery } & 0.015 & $0.059 * *$ & $0.063^{* *}$ \\
\hline & $(0.43)$ & $(2.23)$ & $(2.11)$ \\
\hline \multirow{2}{*}{ Pvda mach. $* \ln (\text { total assets })_{t-1}$} & -0.002 & $-0.008^{* * *}$ & $-0.008^{* *}$ \\
\hline & $(-0.57)$ & $(-2.75)$ & $(-2.48)$ \\
\hline \multirow[t]{2}{*}{ Pvda buildings } & -0.005 & -0.009 & 0.001 \\
\hline & $(-0.41)$ & $(-0.95)$ & $(0.09)$ \\
\hline \multirow{2}{*}{ Pvda buil. $* \ln (\text { total assets })_{t-1}$} & 0.001 & 0.001 & 0.000 \\
\hline & $(0.88)$ & $(1.17)$ & $(0.05)$ \\
\hline \multirow[t]{2}{*}{ Pvda patents } & $0.097^{* * *}$ & & \\
\hline & $(3.23)$ & & \\
\hline \multirow{2}{*}{ Pvda pat. $* \ln (\text { total assets })_{t-1}$} & $-0.013^{* * *}$ & & \\
\hline & $(-3.30)$ & & \\
\hline \multirow{2}{*}{$\operatorname{Ln}(\text { total assets })_{t-1}$} & 0.402 & -0.079 & -0.070 \\
\hline & $(1.40)$ & $(-0.35)$ & $(-0.28)$ \\
\hline \multirow{2}{*}{ Scaled cash flow } & $0.551^{* * *}$ & $0.435^{* * *}$ & $0.548^{* * *}$ \\
\hline & $(3.40)$ & $(3.61)$ & $(3.50)$ \\
\hline \multirow[t]{2}{*}{ Scaled cash flow $t-1$} & $0.141^{* *}$ & $0.121^{* *}$ & $0.141^{* *}$ \\
\hline & $(2.22)$ & $(2.35)$ & $(2.20)$ \\
\hline \multirow[t]{2}{*}{ Leverage $_{t-1}$} & $-0.378^{* * *}$ & $-0.358^{* * *}$ & $-0.420^{* * *}$ \\
\hline & $(-4.09)$ & $(-4.64)$ & $(-45.02)$ \\
\hline \multirow[t]{2}{*}{ Year of incorporation } & -0.015 & -0.042 & -0.027 \\
\hline & $(-0.15)$ & $(-0.52)$ & $(-0.30)$ \\
\hline \multirow[t]{2}{*}{ Profit prior year } & $0.123^{* * *}$ & $0.123^{* * *}$ & $0.135^{* * *}$ \\
\hline & $(3.81)$ & $(4.52)$ & $(4.46)$ \\
\hline \multirow[t]{2}{*}{ Country risk } & 0.061 & 0.063 & 0.067 \\
\hline & $(1.28)$ & $(1.49)$ & $(1.44)$ \\
\hline \multirow[t]{2}{*}{ Unemployment rate } & -0.711 & 0.263 & -0.350 \\
\hline & $(-0.83)$ & $(0.35)$ & $(-0.43)$ \\
\hline \multirow[t]{2}{*}{ Hourly wages } & -0.009 & -0.000 & -0.003 \\
\hline & $(-0.84)$ & $(-0.02)$ & $(-0.34)$ \\
\hline \multirow[t]{2}{*}{ Inflation } & 0.090 & 0.301 & 0.293 \\
\hline & $(0.17)$ & $(0.66)$ & $(0.59)$ \\
\hline \multirow[t]{2}{*}{ Treasury rate } & -3.384 & $-8.167 * * *$ & $-7.308^{* *}$ \\
\hline & $(-0.87)$ & $(-2.58)$ & $(-2.11)$ \\
\hline \multirow[t]{2}{*}{ Market size } & -2.244 & $-3.994^{* *}$ & $-3.733^{*}$ \\
\hline & $(-0.98)$ & $(-2.14)$ & $(-1.83)$ \\
\hline \multirow[t]{2}{*}{ GDP growth } & -0.643 & -1.464 & -1.434 \\
\hline & $(-0.63)$ & $(-1.73)$ & $(-1.53)$ \\
\hline \multirow[t]{2}{*}{ Ln(GDP per capita) } & 0.419 & 0.167 & 0.336 \\
\hline & $(0.63)$ & $(0.29)$ & $(0.53)$ \\
\hline \multirow{2}{*}{ Constant } & 30.424 & $66.074^{*}$ & 60.015 \\
\hline & $(0.69)$ & $(1.84)$ & $(1.53)$ \\
\hline Industry-year fixed effects & Yes & Yes & Yes \\
\hline Firm fixed effects & Yes & Yes & Yes \\
\hline Number of observations & 131,967 & 131,967 & 131,967 \\
\hline Within $\mathrm{R}^{2}$ & 0.031 & 0.028 & 0.031 \\
\hline Prob $>$ F & 0.000 & 0.000 & 0.000 \\
\hline
\end{tabular}

The table shows the linear regression results for firm investment behavior, estimated over the period from 1998 to 2007. The sample includes only companies that do not have tax loss carry-forwards. The dependent variables are different (gross) investment rates, as defined in Section E.4.2. See Table E.11 for a description of the dependent and independent variables. Year, industry-year and firm indicator variables are included in all three specifications but are not reported. Standard errors allow for heteroskedasticity and are clustered by firm; t-values are shown in parentheses. ${ }^{*}, * *$ and ${ }^{* * *}$ indicate statistical significance at the ten-, five- and one-percent level, respectively. Prob $>\mathrm{F}$ is the p-value associated with the F-test for the null hypothesis that all coefficients are equal to zero. 


\section{F Zusammenfassendes Fazit}

Gegenstand der vorliegenden Arbeit sind vier Beiträge, deren Fokus auf Aufkommens-, Verteilungs- und Investitionswirkungen von Steuerreformen liegt. Die Aufkommenswirkungen von Steuerreformen sind insbesondere für die Finanzverwaltungen von Bedeutung, da sichergestellt werden sollte, dass potenzielle Steuerreformen haushaltspolitisch vertretbar sind. Insbesondere für den gezielten Einsatz von Steuerreformen (zum Beispiel zur Förderung bestimmter Unternehmen oder Branchen) sind darüber hinaus die Verteilungswirkungen von Steuerreformen relevant. Neben den direkten Auswirkungen auf das Aufkommen und die Steuerbelastung können sich Steuerreformen auch auf das Verhalten der Unternehmen auswirken. Von besonderem Interesse sind dabei Auswirkungen auf das Investitionsverhalten, da Investitionen einen großen Einfluss auf Wachstum und Beschäftigung haben. In diesem Zusammenhang ist es zunächst entscheidend, die steuerinduzierten Investitionswirkungen zu quantifizieren. Darüber hinaus wäre es wünschenswert, die ermittelten Verhaltenswirkungen als sogenannte Zweitrundeneffekte in die Schätzung von Aufkommens- und Verteilungswirkungen einzubeziehen. Während die ersten drei Beiträge der Quantifizierung von Aufkommens- und Verteilungswirkungen bestimmter Steuerreformoptionen gewidmet sind, werden im vierten Beitrag die Investitionswirkungen von steuerlichen Abschreibungsvorschriften ermittelt.

Im ersten Beitrag werden mit Hilfe eines prototypischen Mikrosimulationsmodells die Aufkommens- und Verteilungswirkungen verschiedener Möglichkeiten zur Reform der steuerlichen Verlustverrechnung in Deutschland untersucht. Die betrachteten Reformoptionen umfassen eine Abschaffung der Mindestbesteuerung, eine Begrenzung des Verlustvortrags auf sieben Jahre und die Abschaffung des Verlustrücktrags. In einem vierten Szenario wird die gleichzeitige Umsetzung aller drei Reformoptionen analysiert.

Mit Hilfe des prototypischen Mikrosimulationsmodells werden zunächst die handelsrechtlichen Ergebnisse für die Jahre von 2007 bis 2012 fortgeschrieben und unter Berücksichtigung des jeweiligen Reformszenarios in das steuerliche Ergebnis übergeleitet. Die Fortschreibung des Ergebnisses erfolgt unter Unsicherheit. Neben den sogenannten Erstrundeneffekten, das heißt den Aufkommenswirkungen, die sich bei ausbleibender Reaktion der Unternehmen auf die Reform ergäben, werden außerdem Aufkommenseffekte unter Einbezug unternehmerischer Verhaltensreaktionen ermittelt. Mögliche Reaktionen der betroffenen Unternehmen werden dabei in Form einer Szenarioanalyse berücksichtigt, wobei die Kapitalstrukturelastizität, die Investitionselas- 
tizität und die Risikoelastizität in die Berechnungen einbezogen werden. Aufgrund möglicher Verzerrungen durch eine nicht repräsentative Stichprobe, wird die Stichprobe auf die Grundgesamtheit hochgerechnet, um durch einen Vergleich des geltenden Rechts mit den einzelnen Reformszenarien relative Aufkommenswirkungen zu ermitteln. Die Fortschreibung der Ergebnisse in die Zukunft hat insbesondere den Vorteil, dass der Abstand zwischen dem Zeitpunkt der Berechnung und der potenziellen Reform minimiert wird. Darüber hinaus ermöglicht diese Vorgehensweise eine vergleichsweise problemlose Implementierung von Verhaltensreaktionen.

Wie erwartet, zeigen die Ergebnisse einen negativen Aufkommenseffekt für die Abschaffung der Mindestbesteuerung und einen positiven Aufkommenseffekt für die Beschränkung des Verlustvortrags auf sieben Jahre sowie für die Abschaffung des Verlustrücktrags. Über die betrachteten sechs Jahre ergibt sich für die simultane Berücksichtigung aller drei Reformoptionen insgesamt ein negativer Aufkommenseffekt. In Bezug auf die Verteilungswirkungen der Reformoptionen zeigt sich insbesondere, dass kleine und mittelgroße Unternehmen stark von der Abschaffung des Verlustrücktrags betroffen wären, während große Unternehmen insbesondere von der Beendigung der Mindestbesteuerung profitierten. Darüber hinaus beträfe die Reform insbesondere Unternehmen, die in stark konjunkturabhängigen Branchen operieren. Der Einbezug von Zweitrundeneffekten zeigt, dass die Reaktionen der Unternehmen auf die Reform besonders im Wege einer Anpassung der Investitionen und des Risikos zu einer Abschwächung oder zu einer Umkehrung des ermittelten negativen Aufkommenseffektes für das vierte Reformszenario führen könnten.

Das im Zusammenhang mit dem ersten Beitrag entwickelte Simulationsmodell dient als Grundlage des Mikrosimulationsmodells ASSERT, dessen technische Darstellung Gegenstand des zweiten Beitrags ist. So wird das prototypische Modell um 18 weitere Länder der Europäischen Union ergänzt, der Fortschreibungsalgorithmus differenzierter ausgestaltet und die Abbildung von nationalen und grenzüberschreitenden Konzernstrukturen ermöglicht. Die Anzahl und die Art der abbildbaren Steuerreformen werden dadurch wesentlich erweitert. So ist es mit ASSERT möglich, nationale Reformen verschiedener europäischer Länder abzubilden sowie die Auswirkungen von Reformen auf europäischer Ebene und von veränderten (grenzüberschreitenden) Gruppenbesteuerungssystemen zu ermitteln. Neben Reformen der Gruppenbesteuerung können mit ASSERT auf dieser erweiterten Ebene zum Beispiel Reformen der intertemporalen Verlustverrechnung, der steuerlichen Behandlung von Dividenden oder der Regelungen zur steuerlichen Abschreibung abgebildet werden. Daneben ist eine Abbildung von Steuersatzeffekten möglich. Eine Evaluierung der Modellgüte, bei der mit ASSERT simulierte Ergebnisse realisierten Daten 
gegenüber gestellt werden, zeigt, dass Fortschreibungs- und Simulationsalgorithmus hinreichende Ergebnisse liefern und somit eine valide Grundlage zur Analyse der Auswirkungen von Steuerreformen darstellen.

Vor dem Hintergrund dieser Ergebnisse wurde das Mikrosimulationsmodell ASSERT bereits in zwei Projekten zur Simulation von Aufkommenswirkungen eingesetzt. Das vom Institut für Finanzen und Steuern geförderte Projekt, in dem mögliche Reformen der Organschaftsbesteuerung in Deutschland untersucht werden, ist Gegenstand des dritten Beitrags dieser Arbeit. Die damit zusammenhängenden Berechnungen basieren auf der Annahme einer Reformeinführung zu Beginn des Jahres 2008. Es werden die Aufkommenseffekte bezogen auf einen Vierjahreszeitraum (2008 bis 2011) analysiert. In einem ersten Untersuchungsschritt werden die Auswirkungen einer Anhebung der Mindesbeteiligungsquote und einer Abschaffung des Ergebnisabführungsvertrags auf die Anzahl der Unternehmen, die die Voraussetzungen für die Inanspruchnahme der Gruppenbesteuerung erfüllen, ermittelt. Während eine höhere Mindestbeteiligungsquote mit einer geringeren Anzahl an Unternehmen, die für die Gruppenbesteuerung optieren könnten, verbunden ist, führt die Abschaffung des Ergebnisabführungsvertrags im Vergleich zum geltenden Recht zu einem sprunghaften Anstieg dieser Unternehmen. Wie erwartet fällt der Anstieg umso kleiner aus, je höher die Mindestbeteiligungsquote festgesetzt wird. Darauf aufbauend werden die Auswirkungen einer Abschaffung des Ergebnisabführungsvertrags als Voraussetzung für die Organschaft und die gleichzeitige Anhebung der Mindestbeteiligungsquote auf das Steueraufkommen untersucht. Die Ergebnisse zeigen, dass diese Reformoption zu einem negativen Aufkommenseffekt führen würde, der umso kleiner ausfällt, je höher die entsprechende Mindestbeteiligungsquote angesetzt wird. Wird neben der Abschaffung des Ergebnisabführungsvertrags sowie einer Anhebung der Mindestbeteiligungsquote auf $75 \%$ zusätzlich die Verlustverrechnung auf den Beteiligungsbuchwert beschränkt, wird der negative Aufkommenseffet, je nach Berechnungsmethode des Beteiligungsbuchwerts, entweder kleiner oder kehrt sich um. Wird die Verlustverrechnung dagegen auf solche Verluste ausgedehnt, die vor Bildung der Organschaft entstanden sind, steigt erwartungsgemäß der negative Aufkommenseffekt. Darüber hinaus zeigen die ermittelten Verteilungswirkungen, dass die Abschaffung des Ergebnisabführungsvertrags mit gleichzeitiger Anhebung der Mindestbeteiligungsquote auf $75 \%$ insbesondere Konzernen mit einer großen Anzahl von Konzerngesellschaften sowie internationalen Konzernen zugute käme.

Zielsetzung des vierten Beitrags ist die empirische Ermittlung des Einflusses der steuerlichen Abschreibung auf das Investitionsverhalten kleiner, mittelständischer und großer europäischer Unternehmen. Die Investitionswirkung steuerlicher Abschreibungsvorschriften war in der Ver- 
gangenheit schon mehrfach Gegenstand empirischer Untersuchungen. Diese bezogen sich jedoch fast ausschließlich auf große und/oder börsennotierte Unternehmen aus den USA. Neben einer Darstellung der theoretischen Grundlagen wird im vierten Beitrag mit Hilfe von Mikrodaten und ökonometrischen Methoden analysiert, ob erweiterte Abschreibungsmöglichkeiten tatsächlich zu dem prognostizierten Anstieg des Investitionsvolumens führen und ob dieser Effekt gegebenenfalls für verschiedene Unternehmen unterschiedlich stark ausgeprägt ist. Dabei wird zwischen Abschreibungsvorschriften für Patente, Gebäude und Maschinen differenziert, wobei die verschiedenen Abschreibungsregelungen durch den Abschreibungsbarwert operationalisiert werden. Die Ergebnisse zeigen zunächst, dass Unternehmen nur dann auf unterschiedliche Steuersätze und Abschreibungsvorschriften reagieren, wenn sie tatsächlich Steuern zahlen, das heißt wenn sie nicht im Besitz steuerlicher Verlustvorträge sind. Für steuerzahlende Unternehmen wird insbesondere ermittelt, dass aus Unternehmenssicht verbesserte Abschreibungsvorschriften für Maschinen mit einer höheren Investitionsrate einhergehen. Dieser Effekt ist umso stärker ausgeprägt, je kleiner das Unternehmen ist, was vermutlich damit zusammenhängt, dass die Nutzung steuerlicher Abschreibungsmöglichkeiten eine der wenigen Steuerplanungsmöglichkeiten für kleine Unternehmen darstellt, während große Unternehmen beispielsweise auch durch Verrechnungspreisgestaltung und andere Methoden Steuerplanung betreiben können. Der Effekt ist sowohl bei Cross-Section- als auch bei Panel-Analysen sowie in einer dynamischen Spezifikation zu finden. Auch bei Ausdehnung des Datensatzes und bei Anwendung eines alternativen Abzinsungssatzes zur Ermittlung des Abschreibungsbarwerts bleibt der Effekt bestehen.

Die empirische Ermittlung und Quantifizierung von unternehmerischen Reaktionen auf steuerliche Änderungen ist für verschiedene Problembereiche der Wirtschaftswissenschaften von erheblicher Bedeutung. Durch die Kenntnis von Verhaltenswirkungen ist es zum Beispiel möglich, Steuerreformen gezielt so auszugestalten, dass gewünschte Verhaltensweisen gefördert und unerwünschtes Verhalten eingeschränkt wird. Daneben ist die Berücksichtigung unternehmerischer Reaktionen bedeutsam, wenn die Auswirkungen von Steuerreformen auf die Beschäftigung, das Investitionsverhalten oder auf das Steueraufkommen prognostiziert werden sollen. Wie bereits im Laufe der Arbeit deutlich wurde, ist es im Sinne einer ganzheitlichen Analyse erstrebenswert, sowohl Erst- als auch Zweitrundeneffekte in die Analyse von steuerreforminduzierten Aufkommenswirkungen einzubeziehen. Die Auswirkung steuerlicher Abschreibungsvorschriften auf das Investitionsverhalten ist dabei nur eine mögliche Form unternehmerischer Reaktionen. So wurde bereits in einigen Studien festgestellt, dass ein hoher Steuersatz tendenziell mit einer hohen Fremdkapitalquote verbunden ist (siehe zum Beispiel Desai et al., 2004 oder Huizinga et al., 
2008). Andere Analysen beschäftigen sich mit dem Einfluss von steuerlichen Verlustverrechnungsvorschriften auf das Investitionsverhalten (siehe Dreßler \& Overesch, 2013) oder auf die unternehmerische Risikoübernahme (siehe Koch \& Prassel, 2011). Um die Prognosefähigkeit des Mikrosimulationsmodells ASSERT weiter auszubauen, sollen die im vierten Beitrag ermittelten Verhaltensreaktionen sowie weitere Verhaltenswirkungen langfristig in das Modell integriert werden. 


\section{Literaturverzeichnis}

[Altfelder, 2000] Altfelder, S. Mindestbesteuerung - Chaos mit System? In: Finanz-Rundschau 82 (2000), pp. 18-43

[Alvarez et al., 2001] Alvarez, F., Lucas, R.E., Weber, W.E. Interest Rates and Inflation. In: The American Economic Review 91 (2001), pp. 219-225

[Arellano, 2003] Arellano, M. Panel Data Econometrics. Oxford University Press 2003

[Arellano \& Bond, 1991] Arellano, M., Bond, S. Some Tests of Specification for Panel Data: Monte Carlo Evidence and an Application to Employment Equations. In: The Review of Economic Studies 58 (1991), pp. 277-297

[Arellano \& Bover, 1995] Arellano, M., Bover, O. Another look at the instrumental variable estimation of error-components models. In: Journal of Econometrics 68 (1995), pp. 29-51

[Bach et al., 2008] Bach, S., Buslei, H., Dwenger, N., Fossen, F. Dokumentation des Mikrosimulationsmodells BizTax zur Unternehmensbesteuerung in Deutschland. Data Documentation 29, DIW Berlin 2008

[Bailey, 1959] Bailey, M. Formal Criteria for Investment Decisions. In: The Journal of Political Economy 67 (1959), pp. 476-488

[Bartik, 1985] Bartik, T. Business Location Decisions in the United States: Estimates of the Effects of Unionization, Taxes, and Other Characteristics of States. In: Journal of Business and Economic Statistics 3 (1985), pp. 14-22

[Becker et al., 2013] Becker, B., Jacob, M., Jacob, M. Payout taxes and the allocation of investment. In: Journal of Financial Economics 107 (2013), pp. 1-24

[Behr, 2003] Behr, A. A comparison of dynamic panel data estimators: Monte Carlo evidence and an application to the investment function. Deutsche Bundesbank 2003

[Blouin et al., 2010] Blouin, J., Core, J.E., Guay, W.R. Have the tax benefits of debt been overestimated? In: Journal of Financial Economics 98 (2010), pp. 195-213

[Blundell \& Bond, 1998] Blundell, R., Bond, S. Initial Conditions and Moment Restrictions in Dynamic Panel Data Models. In: Journal of Econometrics 87 (1998), pp. 115-143

[Bontempi et al., 2005] Bontempi, M.E., Giannini, S., Golinelli, R. Corporate tax reforms and financial choices: an empirical analysis. In: Giornale degli Economisti e Annali di Economia 64 (2005), pp. 271-294

[Buettner \& Ruf, 2007] Buettner, T., Ruf, M. Tax incentives and the location of FDI: Evidence from a panel of German multinationals. In: International Tax and Public Finance 14 (2007), pp. 151-164

[Büttner \& Kauder, 2008] Büttner, T., Kauder, B. Steuerschätzung im internationalen Vergleich. In: Monatsbericht des BMF (2008), pp. 55-65

[Büttner \& Kauder, 2010] Büttner, T., Kauder, B. Revenue Forecasting Practices: Differences across Countries and Consequences for Forecasting Performance. In: Fiscal Studies 31 (2010), pp. 313-340

[Castellucci et al., 2003] Castellucci, L., Coromaldi, M., Parisi, V., Perlini, L., Zoli, M. Report Describing Results and Country IT Tax Schedule Model. Technical Report, University of Rome Tor Vergata 2003 
[CDU et al., 2009] CDU, CSU, FDP. Wachstum. Bildung. Zusammenhalt. Koalitionsvertrag zwischen CDU, CSU und FDP, 17. Legislaturperiode 2009

[Chirinko, 1993] Chirinko, R. Business Fixed Investment Spending: Modeling Strategies, Empirical Results, and Policy Implications. In: Journal of Economic Literature 31 (1993), pp. $1875-1911$

[Chirinko et al., 1999] Chirinko, R., Fazzari, S., Meyer, A. How responsive is business capital formation to its user cost? An exploration with micro data. In: Journal of Public Economics 74 (1999), pp. 53-80

[Chirinko \& Wilson, 2008] Chirinko, R.S., Wilson, D.J. State investment tax incentives: A zerosum game? In: Journal of Public Economics 92 (2008), pp. 2362-2384

[Clark, 1979] Clark, P.K. Investment in the 1970s: Theory, Performance, and Prediction. In: Brookings Papers on Economic Activity 1 (1979), pp. 73-124

[Clark, 1993] Clark, P.K. Tax Incentives and Equipment Investment. In: Brookings Papers on Economic Activity 1 (1993), pp. 317-347

[Cohen \& Cummins, 2006] Cohen, D., Cummins, J. A Retrospective Evaluation of the Effects of Temporary Partial Expensing. Finance and Economics Discussion Series, Divisions of Research \& Statistics and Monetary Affairs - Federal Reserve Board, Washington, D.C. 2006

[Collins \& Shackelford, 1995] Collins, J.H., Shackelford, D.A. Corporate Domicile and Average Effective Tax Rates: The Cases of Canada, Japan, the United Kingdom, and the United States. In: International Tax and Public Finance 2 (1995), pp. 55-83

[Creedy \& Gemmell, 2007] Creedy, J., Gemmell, N. Corporation Tax Revenue Growth in the UK: A Microsimulation Analysis. Research Paper Number 984, The University of Melbourne - Department of Economics 2007

[Cummins et al., 1994] Cummins, J., Hassett, K., Hubbard, R., Hall, R., Caballero, R. A Reconsideration of Investment Behavior Using Tax Reforms as Natural Experiments. In: Brookings Papers on Economic Activity 2 (1994), pp. 1-74

[Cummins \& Hassett, 1992] Cummins, J.G., Hassett, K.A. The Effects of Taxation on Investment: New Evidence from Firm Level Panel Data. In: National Tax Journal 45 (1992), pp. $243-252$

[Dauchy \& Martínez, 2008] Dauchy, E., Martínez, C. Corporate Tax Minimization and the Effectiveness of Investment Tax Incentives. In: Proceedings of the 100th Annual Conference on Taxation. National Tax Association 2008

[DeAngelo \& Masulis, 1980] DeAngelo, H., Masulis, R. Optimal capital structure under corporate and personal taxation. In: Journal of Financial Economics 8 (1980), pp. 3-29

[Desai \& Goolsbee, 2004] Desai, M., Goolsbee, A. Investment, Overhang, and Tax Policy. In: Brookings Papers on Economic Activity 2 (2004), pp. 285-355

[Desai et al., 2004] Desai, M.A., Foley, C.F., Hines, J.R. A Multinational Perspective on Capital Structure Choice and Internal Capital Markets. In: Journal of Finance 59 (2004), pp. $2451-2487$

[Destatis, 2009a] Destatis. Statistisches Bundesamt. Gewerbesteuer 2004. Wiesbaden 2009a

[Destatis, 2009b] Destatis. Statistisches Bundesamt. Körperschaftsteuerstatistik 2004. Wiesbaden $2009 \mathrm{~b}$ 
[Destatis, 2010] Destatis. Statistisches Bundesamt. Jährliche Körperschaftsteuerstatistik 2006. Wiesbaden 2010

[Destatis, 2011] Destatis. Statistisches Bundesamt. Jährliche Körperschaftsteuerstatistik 2007. Wiesbaden 2011

[Destatis, 2012] Destatis. Statistisches Bundesamt. Gewerbesteuer 2007. Wiesbaden 2012

[Deutsche Bundesbank, 2010] Deutsche Bundesbank. Verhältniszahlen aus Jahresabschlüssen deutscher Unternehmen von 2006 bis 2007. Statistische Sonderveröffentlichung 6, Frankfurt am Main 2010

[Deutsche Bundesbank, 2011] Deutsche Bundesbank. Bestandserhebung über Direktinvestitionen. Statistische Sonderveröffentlichung 10, Frankfurt am Main 2011

[Devereux \& Griffith, 1998] Devereux, M., Griffith, R. Taxes and the Location of Production: Evidence from a Panel of US Multinationals. In: Journal of Public Economics 68 (1998), pp. $335-367$

[Devereux et al., 2009] Devereux, M.P., Elschner, C., Endres, D., Spengel, C. Report 2009 - Effective tax levels using the Devereux/Griffith methodology. Project for the EU Commission TAXUD/2008/CC/099, European Commission 2009

[Devereux \& Griffith, 1999] Devereux, M.P., Griffith, R. The taxation of discrete investment choices. Working Paper Series No. W98/16, The Institute for Fiscal Studies 1999

[Devereux \& Maffini, 2006] Devereux, M.P., Maffini, G. The impact of taxation on the location of capital, firms and profit: A survey of empirical evidence. Working Paper, University of Warwick, IFS, CEPR 2006

[Dhaliwal et al., 1992] Dhaliwal, D., Trezevant, R., Wang, S. Taxes, investment-related tax shields and capital structure. In: Journal of the American Taxation Association 14 (1992), pp. $1-21$

[Diamond \& Zodrow, 2008] Diamond, J.W., Zodrow, G.R. (Eds.). Fundamental tax reform: issues, choices, and implications. MIT Press, Cambridge 2008

[Domar \& Musgrave, 1944] Domar, E.D., Musgrave, R.A. Proportional Income Taxation and Risk-Taking. In: The Quarterly Journal of Economics 58 (1944), pp. 388-422

[Dorenkamp, 2010] Dorenkamp, C. Systemgerechte Neuordnung der Verlustverrechnung Haushaltsverträglicher Ausstieg aus der Mindestbesteuerung. IFSt-Schrift Nr. 461, Bonn 2010

[Dreßler \& Overesch, 2012] Dreßler, D., Overesch, M. Investment Impact of Tax Loss Treatment. In: International Tax and Public Finance DOI: 10.1007/s10797-012-9240-1 (2012)

[Dreßler \& Overesch, 2013] Dreßler, D., Overesch, M. Investment Impact of Tax Loss Treatment. In: International Tax and Public Finance 20 (2013), p. 513-543

[Duesenberry et al., 1965] Duesenberry, J.S., Fromm, G., Klein, L.R., Kuh, E. (Eds.). The Brookings Quarterly Econometric Model of the United States. Rand McNally \& Company - Chicago 1965

[Dwenger, 2008] Dwenger, N. Tax Loss Offset Restrictions - Last Resort for the Treasury? - An Empirical Evaluation of Tax Loss Offset Restrictions Based on Micro Data. Discussion Papers 764, DIW Berlin 2008 
[Dwenger, 2010] Dwenger, N. User cost elasticity of capital revisited. Working Paper, Max Planck Institute for Intellectual Property, Competition and Tax Law, Department Public Economics 2010

[Edgerton, 2011] Edgerton, J. The Effects of Taxation on Business Investment: New Evidence from Used Equipment. Working Paper, Federal Reserve Board 2011

[Edgerton, 2012] Edgerton, J. Investment, Accounting, and the Salience of the Corporate Income Tax. NBER Working Paper Series 18472, National Bureau of Economic Research 2012

[Endres et al., 2007] Endres, D., Oestreicher, A., Scheffler, W., Spengel, C. The Determination of Corporate Taxable Income in the EU Member States. Kluwer Law International 2007

[Europäische Kommission, 2012] Europäische Kommission. Kommission verklagt Deutschland wegen steuerlicher Behandlung von Organgesellschaften - Pressemitteilung - IP/12/283 2012

[European Commission, 2011] European Commission. Impact Assessment - Accompanying document to the Proposal for a Council Directive on a Common Consolidated Corporate Tax Base (CCCTB) - SEC(2011) 3152011

[Fairfield et al., 2009] Fairfield, P.M., Ramnath, S., Yohn, T.L. Do Industry-Level Analyses Improve Forecasts of Financial Performance? In: Journal of Accounting Research 47 (2009), pp. $147-178$

[Fama \& French, 2000] Fama, E., French, K. Forecasting Profitability and Earnings. In: Journal of Business 73 (2000), pp. 161-175

[Feld et al., 2011] Feld, L., Heckemeyer, J., Overesch, M. Capital Structure Choice and Company Taxation: A Meta-Study. CESifo Working Paper No. 3400, University of Freiburg, Center for European Economic Research (ZEW), University of Mannheim 2011

[Feldstein, 1987] Feldstein, M. (Ed.). The Effects of Taxation on Capital Accumulation. University of Chicago Press 1987

[Fellinger \& Schmidt-Fehrenbacher, 2012] Fellinger, A., Schmidt-Fehrenbacher, V. Finale EUAuslandsverluste: Drohpotential für das Steueraufkommen? In: Die Unternehmensbesteuerung 5 (2012), pp. 217-222

[Finance-Expertenpanel, 2011] Finance-Expertenpanel. Finance-Multiples 2011

[Fromm, 1971] Fromm, G. (Ed.). Tax Incentives and Capital Spending. Washington, DC: The Brookings Institution 1971

[Graham, 1996a] Graham, J. Debt and the marginal tax rate. In: Journal of Financial Economics 41 (1996a), pp. 41-73

[Graham, 1996b] Graham, J. Proxies for the corporate marginal tax rate. In: Journal of Financial Economics 42 (1996b), pp. 187-221

[Graham \& Kim, 2009] Graham, J., Kim, H. Simulating Corporate Marginal Income Tax Rates and Implications for Corporate Debt Policy. Working Paper, Duke University 2009

[Graham et al., 1998] Graham, J., Lemmon, M., Schallheim, J. Debt, Leases, Taxes, and the Endogeneity of Corporate Tax Status. In: Journal of Finance 53 (1998), pp. 131-162

[Grotherr, 1998] Grotherr, S. Steht der Verlustvor- und -rücktrag steuerpolitisch zur Diskussion? In: BetriebsBerater 46/47 (1998), pp. 2337-2397 
[Hackmann, 2006] Hackmann, J. Verfassungswidrigkeit der neuen Mindestbesteuerung? - Anmerkungen zur Abhandlung von J. Land und J. Englisch, StuW 2005, 3. In: Steuer und Wirtschaft 83 (2006), pp. 124-133

[Haegert \& Kramm, 1975] Haegert, L., Kramm, R. Der Einfluß von Ertragsteuern auf die Vorteilhaftigkeit von Investitionen mit unterschiedlichem Risiko. In: Zeitschrift für betriebswirtschaftliche Forschung 27 (1975), pp. 69-83

[Hall \& Jorgenson, 1967] Hall, R., Jorgenson, D. Tax Policy and Investment Behavior. In: The American Economic Review 57 (1967), pp. 391-414

[Hall \& Jorgenson, 1971] Hall, R., Jorgenson, D. Application of the Theory of Optimum Capital Accumulation. In: G. Fromm (Ed.), Tax Incentives and Capital Spending. Washington, DC: The Brookings Institution 1971, pp. 9-60

[Hanlon \& Heitzman, 2010] Hanlon, M., Heitzman, S. A review of tax research. In: Journal of Accounting and Economics 50 (2010), pp. 127-178

[Hansen, 1982] Hansen, L. Large Sample Properties of Generalized Method of Moments Estimators. In: Econometrica: Journal of the Econometric Society 50 (1982), pp. 1029-1054

[Hartman, 1985] Hartman, D. Tax Policy and Foreign Direct Investment in the United States. In: National Tax Journal 37 (1985), pp. 475-487

[Hassett \& Hubbard, 2002] Hassett, K., Hubbard, R. Tax policy and business investment. In: Handbook of Public Economics 3 (2002), pp. 1293-1343

[Hassett \& Newmark, 2008] Hassett, K., Newmark, K. Taxation and Business Behavior: A Review of the Recent Literature. In: J.W. Diamond, G.R. Zodrow (Eds.), Fundamental tax reform: issues, choices, and implications. MIT Press, Cambridge 2008, pp. 191-214

[Heckemeyer \& Overesch, 2012] Heckemeyer, J.H., Overesch, M. Auswirkungen der Besteuerung auf Entscheidungen international tätiger Unternehmen. Ein Überblick zu den empirischen Befunden. In: Die Betriebswirtschaft 72 (2012), pp. 451-472

[Herzig \& Wagner, 2004] Herzig, N., Wagner, T. Mindestbesteuerung durch die Begrenzung der Verrechnung von Verlustvorträgen. In: Die Wirtschaftsprüfung 57 (2004), pp. 53-64

[Hines, 1999] Hines, J.R. Lessons from Behavioral Responses to International Taxation. In: National Tax Journal 52 (1999), pp. 305-322

[Hirshleifer, 1958] Hirshleifer, J. On the Theory of Optimal Investment Decision. In: The Journal of Political Economy 66 (1958), pp. 329-352

[House \& Shapiro, 2008] House, C., Shapiro, M. Temporary Investment Tax Incentives: Theory with Evidence from Bonus Depreciation. In: The American Economic Review 98 (2008), pp. $737-768$

[Huizinga et al., 2008] Huizinga, H., Laeven, L., Nicodeme, G. Capital structure and international debt shifting. In: Journal of Financial Economics 88 (2008), pp. 80-118

[Hulse \& Livingstone, 2010] Hulse, D.S., Livingstone, J.R. Incentive effects of bonus depreciation. In: Journal of Accounting and Public Policy 29 (2010), pp. 578-603

[IFSt-Arbeitsgruppe, 2011] IFSt-Arbeitsgruppe. Einführung einer modernen Gruppenbesteuerung: ein Reformvorschlag. IFSt-Schrift Nr. 471, Berlin 2011

[Jorgenson, 1963] Jorgenson, D.W. Capital Theory and Investment Behavior. In: American Economic Review 53 (1963), pp. 247-259 
[Jorgenson, 1965] Jorgenson, D.W. Anticipations and Investment Behavior. In: J.S. Duesenberry, G. Fromm, L.R. Klein, E. Kuh (Eds.), The Brookings Quarterly Econometric Model of the United States. Rand McNally \& Company - Chicago 1965, pp. 34-92

[Jorgenson, 1967] Jorgenson, D.W. The Theory of Investment Behavior. In: Determinants of Investment Behavior. NBER 1967, pp. 129-188

[Jorgenson \& Siebert, 1968a] Jorgenson, D.W., Siebert, C.D. A Comparison of Alternative Theories of Corporate Investment Behavior. In: The American Economic Review 58 (1968a), pp. $681-712$

[Jorgenson \& Siebert, 1968b] Jorgenson, D.W., Siebert, C.D. Optimal Capital Accumulation and Corporate Investment Behavior. In: The Journal of Political Economy 76 (1968b), pp. $1123-1151$

[Kesti, 2001] Kesti, J. (Ed.). European Tax Handbook 2001. International Bureau of Fiscal Documentation, Amsterdam 2001

[Kesti, 2002] Kesti, J. (Ed.). European Tax Handbook 2002. International Bureau of Fiscal Documentation, Amsterdam 2002

[Kesti, 2003] Kesti, J. (Ed.). European Tax Handbook 2003. International Bureau of Fiscal Documentation, Amsterdam 2003

[Kesti, 2004] Kesti, J. (Ed.). European Tax Handbook 2004. International Bureau of Fiscal Documentation, Amsterdam 2004

[Kesti, 2005] Kesti, J. (Ed.). European Tax Handbook 2005. International Bureau of Fiscal Documentation, Amsterdam 2005

[Kesti, 2006] Kesti, J. (Ed.). European Tax Handbook 2006. International Bureau of Fiscal Documentation, Amsterdam 2006

[Kesti, 2007] Kesti, J. (Ed.). European Tax Handbook 2007. International Bureau of Fiscal Documentation, Amsterdam 2007

[Kesti \& Andersen, 1998] Kesti, J., Andersen, P.S. (Eds.). European Tax Handbook 1998. International Bureau of Fiscal Documentation, Amsterdam 1998

[Kesti et al., 1999] Kesti, J., Andersen, P.S., Swanhagen, C. (Eds.). European Tax Handbook 1999. International Bureau of Fiscal Documentation, Amsterdam 1999

[Kesti \& Balle, 2000] Kesti, J., Balle, C.H. (Eds.). European Tax Handbook 2000. International Bureau of Fiscal Documentation, Amsterdam 2000

[Key, 2008] Key, K.G. Taxes and asset prices: The case of thoroughbreds. In: Journal of the American Taxation Association 30 (2008), pp. 29-48

[Kirchhof et al., 2001] Kirchhof, P., Altehoefer, K., Arndt, H.W., Bareis, P., Eckmann, G., Freudenberg, R., Hahnemann, M., Kopie, D., Lang, F., Lückhardt, J., Schutter, E. Dokumentation: Karlsruher Entwurf zur Reform des Einkommensteuergesetzes. In: Deutsches Steuerrecht 23 (2001), pp. 917-920

[Klemm \& Van Parys, 2012] Klemm, A., Van Parys, S. Empirical evidence on the effects of tax incentives. In: International Tax and Public Finance 19 (2012), pp. 393-423

[Koch, 2010] Koch, R. Die Aufkommens- und Belastungswirkungen alternativer Vorschläge zur Reform der Konzernbesteuerung in Europa. Dissertation, Georg-August-Universität Göttingen 2010 
[Koch, 2011] Koch, R. On the accuracy of simulated marginal tax rates. Working Paper, GeorgAugust-Universität Göttingen 2011

[Koch \& Prassel, 2011] Koch, R., Prassel, J. Impact of a reform of the fiscal loss compensation rules on the readiness to company risk-taking. FAT Working Paper, Georg-AugustUniversität Göttingen, Faculty of Economic Sciences 2011

[Landau \& Lifshitz, 1976] Landau, L.D., Lifshitz, E.M. Mechanics. Course of Theoretical Physics. Pergamon Press 1976, 3rd edition

[Lang \& Englisch, 2005] Lang, J., Englisch, J. Zur Verfassungswidrigkeit der neuen Mindestbesteuerung. In: Steuer und Wirtschaft 82 (2005), pp. 3-24

[Lüdicke et al., 2010] Lüdicke, J., Kempf, A., Brink, T. Verluste im Steuerrecht. Nomos 2010

[MacKie-Mason, 1990] MacKie-Mason, J.K. Do Taxes Affect Corporate Financing Decisions? In: Journal of Finance 45 (1990), pp. 1471-93

[Miller et al., 2008] Miller, K.C., Shaw, J.R., Flesher, T.K. Bonus depreciation incentives: The impact on general aviation aircraft. In: Advances in Taxation 18 (2008), pp. 73-101

[Möhlenbrock, 2010] Möhlenbrock, R. Perspektiven der Verlustnutzung bei Körperschaften und deren Anteilseignern. In: Die Unternehmensbesteuerung 4 (2010), pp. 256-265

[Mossin, 1968] Mossin, J. Taxation and Risk-Taking: An Expected Utility Approach. In: Economica 35 (1968), pp. $74-82$

[Müller, 2006] Müller, H. Ausmaß der steuerlichen Verlustverrechnung - Eine empirische Analyse der Aufkommens- und Verteilungswirkungen. Diskussionsbeitrag Nr. 17, arqus - Arbeitskreis quantitative Steuerlehre 2006

[Müller-Gatermann, 2005] Müller-Gatermann, G. Überlegungen zu einer rechtsform- und organisationsformneutralen Gruppenbesteuerung. In: A. Oestreicher (Ed.), Konzernbesteuerung - Beiträge zu einer Ringveranstaltung an der Universität Göttingen im Sommersemester 2004. Herne/Berlin (NWB) 2005

[Müller-Gatermann, 2010] Müller-Gatermann, G. Unternehmenssteuerrecht nach der Wahl. In: Die Unternehmensbesteuerung 3 (2010), pp. 153-161

[Nickell, 1981] Nickell, S. Biases in Dynamic Models with Fixed Effects. In: Econometrica: Journal of the Econometric Society 49 (1981), pp. 1417-1426

[Nicodème, 2001] Nicodème, G. Computing effective corporate tax rates: comparisons and results. MPRA Paper No. 3808, European Commission, DG Economics and Financial Affairs 2001

[Oestreicher, 2005] Oestreicher, A. (Ed.). Konzernbesteuerung - Beiträge zu einer Ringveranstaltung an der Universität Göttingen im Sommersemester 2004. Herne/Berlin (NWB) 2005

[Oestreicher \& Koch, 2010] Oestreicher, A., Koch, R. The determinants of opting for the German group taxation regime with regard to taxes on corporate profits. In: Review of Managerial Science 4 (2010), pp. 119-147

[Oestreicher \& Koch, 2011] Oestreicher, A., Koch, R. The Revenue Consequences of Using a Common Consolidated Corporate Tax Base to Determine Taxable Income in the EU Member States. In: FinanzArchiv 67 (2011), pp. 64-102 
[Oestreicher et al., 2012] Oestreicher, A., Koch, R., Vorndamme, D., Hohls, S. Aufkommenswirkungen einer Abschaffung des Ergebnisabführungsvertrags bei der ertragsteuerlichen Organschaft. IFSt-Schrift Nr. 482, Berlin 2012

[Oestreicher et al., 2013] Oestreicher, A., Koch, R., Vorndamme, D., Hohls, S. ASSERT - Assessing the effects of reforms in taxation - a micro-simulation approach. Technical Report, Georg-August-Universität Göttingen 2013

[Oestreicher et al., 2008] Oestreicher, A., Scheffler, W., Spengel, C., Wellisch, D. Modelle einer Konzernbesteuerung für Deutschland und Europa. Nomos 2008

[Oestreicher \& Spengel, 2002] Oestreicher, A., Spengel, C. Analyse handels- und steuerrechtlicher Abschreibungsregeln - Gutachten im Auftrag des Bundesministeriums der Finanzen. Abschlussbericht, Georg-August-Universität Göttingen, ZEW Zentrum für Europäische Wirtschaftsforschung 2002

[Oropallo \& Parisi, 2005] Oropallo, F., Parisi, V. Will Italy's Tax Reform Reduce the Corporate Tax Burden? A Microsimulation Analysis. Working Paper No. 403, ISTAT, University of Cassino 2005

[Orth, 2005] Orth, M. Die Bedeutung des Gewinnabführungsvertrags für die Besteuerung des Konzernerfolgs. In: A. Oestreicher (Ed.), Konzernbesteuerung - Beiträge zu einer Ringveranstaltung an der Universität Göttingen im Sommersemester 2004. Herne/Berlin (NWB) 2005

[Österreichisches BMF, 2011] Österreichisches BMF. Fachgespräch mit Dr. Maria Fekter Steuerwettbewerb als Standortvorteil, Teil 1. Österreichisches Bundesministerium für Finanzen - Facts and Figures, Wien 2011

[Overesch, 2009] Overesch, M. Besteuerung und Entscheidungen von grenzüberschreitend tätigen Unternehmen - Eine empirische Steuerwirkungsanalyse. Dissertation, Universität Mannheim 2009

[Park, 2011] Park, J. The Impact of Depreciation Savings on Investment: Evidence from the Corporate Alternative Minimum Tax. Working Paper, University of Michigan 2011

[Plesko, 2003] Plesko, G. An evaluation of alternative measures of corporate tax rates. In: Journal of Accounting and Economics 35 (2003), pp. 201-226

[Poppe, 2007] Poppe, A. Auswirkungen der Einführung einer konsolidierten KörperschaftsteuerBemessungsgrundlage in der Europäischen Union. Dissertation, Georg-August-Universität Göttingen 2007

[Reister et al., 2008] Reister, T., Spengel, C., Heckemeyer, J., Finke, K. ZEW Corporate Taxation Microsimulation Model (ZEW TaxCoMM). Discussion Paper No. 08-117, ZEW Zentrum für Europäische Wirtschaftsforschung 2008

[Rödder, 2010] Rödder, T. Perspektiven der Unternehmensbesteuerung (Wachstumsbeschleunigungsgesetz, Koalitionsvertrag). In: Die Unternehmensbesteuerung 3 (2010), pp. 162-168

[Roodman, 2009] Roodman, D. How to do xtabond2: An introduction to difference and system GMM in Stata. In: Stata Journal 9 (2009), pp. 86-136

[Schneider, 1992] Schneider, D. Investition, Finanzierung und Besteuerung. Gabler 1992

[Schneider, 2002] Schneider, D. Steuerlast und Steuerwirkung: Einführung in die steuerliche Betriebswirtschaftslehre. Oldenbourg 2002 
[Schratzenstaller, 2004] Schratzenstaller, M. Zur Ermittlung der faktischen effektiven Unternehmenssteuerlast. In: Perspektiven der Unternehmensbesteuerung. Schratzenstaller, M. and Truger, A. 2004, pp. 43-76

[Shackelford \& Shevlin, 2001] Shackelford, D.A., Shevlin, T. Empirical tax research in accounting. In: Journal of Accounting and Economics 31 (2001), pp. 321-387

[Shevlin, 1990] Shevlin, T. Estimating Corporate Marginal Tax Rates with Asymmetric Tax Treatment of Gains and Losses. In: Journal of the American Taxation Association 11 (1990), pp. 51-67

[Stiglitz, 1969] Stiglitz, J. The Effects of Income, Wealth, and Capital Gains Taxation on RiskTaking. In: The Quarterly Journal of Economics 83 (1969), p. 263

[Summers, 1981] Summers, L. Taxation and Corporate Investment: A q-Theory Approach. In: Brookings Papers on Economic Activity 1 (1981), pp. 67-140

[Summers, 1987] Summers, L. Investment Incentives and the Discounting of Depreciation Allowances. In: M. Feldstein (Ed.), The Effects of Taxation on Capital Accumulation. University of Chicago Press 1987, pp. 295-304

[Tobin, 1958] Tobin, J. Liquidity Preference as Behavior Towards Risk. In: The Review of Economic Studies 25 (1958), pp. 65-86

[Tobin, 1969] Tobin, J. A General Equilibrium Approach to Monetary Theory. In: Journal of Money, Credit and Banking 1 (1969), pp. 15-29

[Windmeijer, 2005] Windmeijer, F. A Finite Sample Correction for the Variance of Linear Efficient Two-Step GMM Estimators. In: Journal of Econometrics 126 (2005), pp. 25-51

[Witte, 1963] Witte, J. The Microfoundations of the Social Investment Function. In: The Journal of Political Economy 71 (1963), pp. 441-456

[Wooldridge, 2009] Wooldridge, J. Introductory Econometrics: A Modern Approach. SouthWestern Pub 2009

[Wymenga et al., 2012] Wymenga, P., Spanikova, V., Barker, A., Konings, J., Canton, E. EU SMEs in 2012: At the crossroads: Annual report on small and medium-sized enterprises in the EU, 2011/12. Report on behalf of the European Commission, ECORYS Nederland BV 2012

[Zimmerman, 1983] Zimmerman, J. Taxes and firm size. In: Journal of Accounting and Economics 5 (1983), pp. 119-149 


\section{Rechtsprechungsverzeichnis}

$\begin{array}{llll}\text { Gericht } & \text { Datum } & \text { Aktenzeichen } & \text { Fundstelle } \\ \text { BFH } & 09.06 .2010 & \text { I R 107/09 } & \text { BStBl II 2009, S. 630 } \\ \text { BFH } & 13.10 .2010 & \text { I R } 79 / 09 & \text { DStRE 2011, S. 223 Nr. 4 } \\ \text { BFH } & 09.11 .2010 & \text { I R } 16 / 10 & \text { DStRE 2011, S. 255 Nr. 4 } \\ \text { BFH } & 09.02 .2011 & \text { I R } 54,55 / 10 & \text { BStBl II 2012, S. } 106 \\ \text { EuGH } & 13.12 .2005 & \text { C } 446 / 03 & \text { DStRE 2006, S. 63 Nr. } 1 \\ \text { EuGH } & 18.07 .2007 & \text { C } 231 / 05 & \text { DStRE 2008, S. 285 Nr. 5 } \\ \text { EuGH } & 15.05 .2008 & \text { C } 414 / 06 & \text { BStBl II 2009, S. } 692 \\ \text { EuGH } & 25.02 .2010 & \text { C } 337 / 08 & \text { DStRE 2010, S. } 388 \text { Nr. } 6\end{array}$




\section{Quellenverzeichnis}

\section{Bundestags-Drucksachen}

Bundestags-Drucksache 16/643 vom 14.02.2006, Entwurf eines Gesetzes zur steuerlichen Förderung von Wachstum und Beschäftigung, S. 1-12

Bundestags-Drucksache 17/4279 vom 16.12.2010, Verlustverrechnung und Mindestbesteuerung in der Unternehmensbesteuerung, S. 1-8

Erlasse, Schreiben und (Rund-) Verfügungen der Finanzverwaltung

BMF-Schreiben vom 28.03.2011 IV C 2 - S 2770/09/10001, BStBl I 2011, S. 300

BMF-Schreiben vom 27.12.2011 IV C 2 - S 2770/11/10002, BStBl I 2012, S. 119

\section{Regierungsvorlagen des österreichischen Parlaments}

Österreichisches Steuerreformgesetz 2005, 451 der Beilagen zu den Stenographischen Protokollen des Nationalrates XXII. GP, öBGBl. I Nr. 57/2004

\section{Richtlinien und Vorschläge auf EU-Ebene}

Council Directive of 23 July 1990 (90/435/EEC) on the common system of taxation applicable in the case of parent companies and subsidiaries of different Member States, Official Journal L 225, berichtigt durch Official Journal L 007

Proposal for a Council Directive on a Common Consolidated Corporate Tax Base (CCCTB), $\operatorname{COM}(2011) 121 / 4$ 